
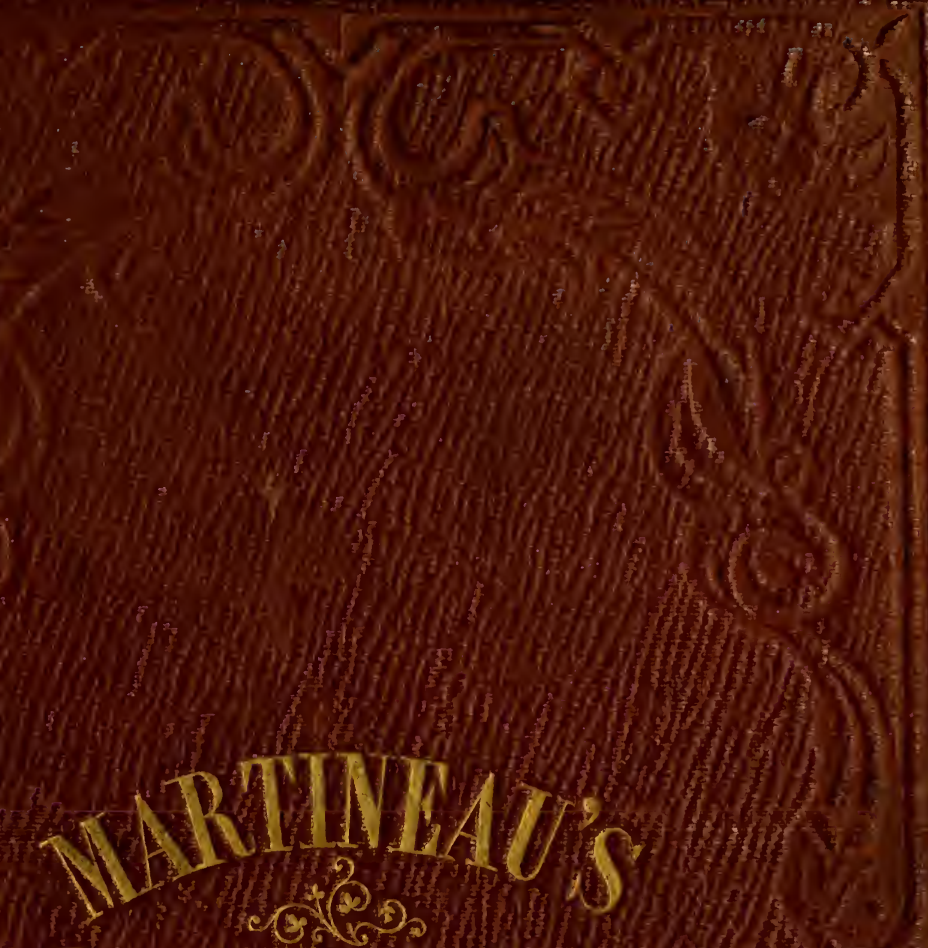

Comolets (Gintos

\title{
ENGISH LAMS.
}

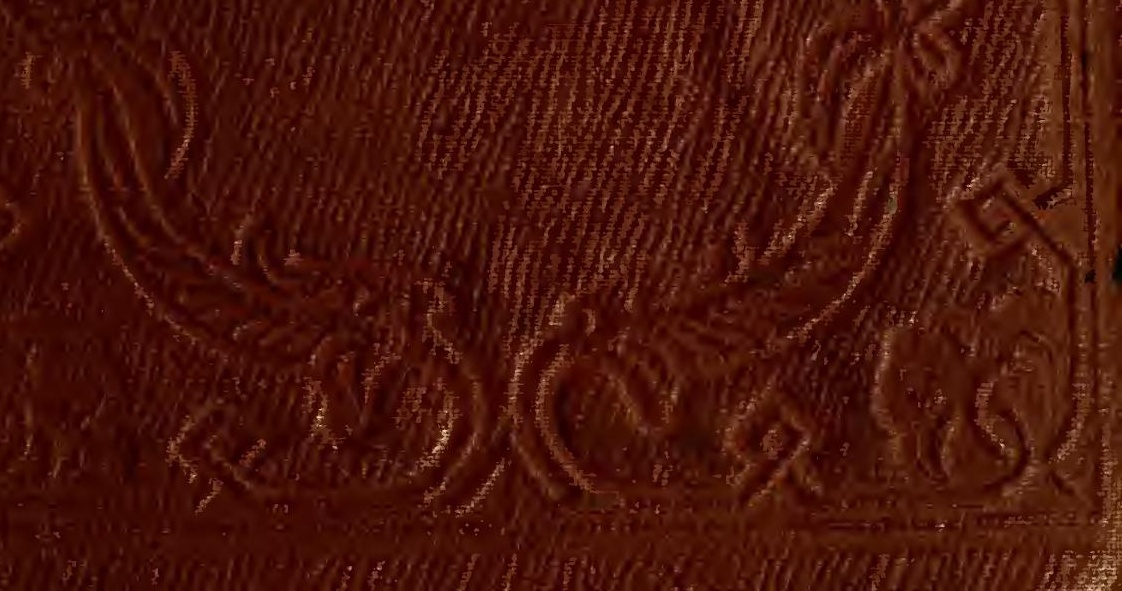




\section{F 746}

\section{Boston Public Library}

PURCHASED FROM THE

James Lyman Whitney

MEMORIAL FUND ESTABLISHED BY

James Lyman Whitney

BIBLIOGRAPHER

AND SOMETIME LIBRARIAN 
II W.

$\lim 28 x=$

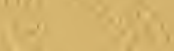

$8_{2} \log ^{10}$

$=$ sin.

. 
$F$

$x^{2}+46$

H. 


\section{COMPLETE GUIDE}

TO THE

\section{ENGLISH LAKES.}




\section{$x^{2}$}
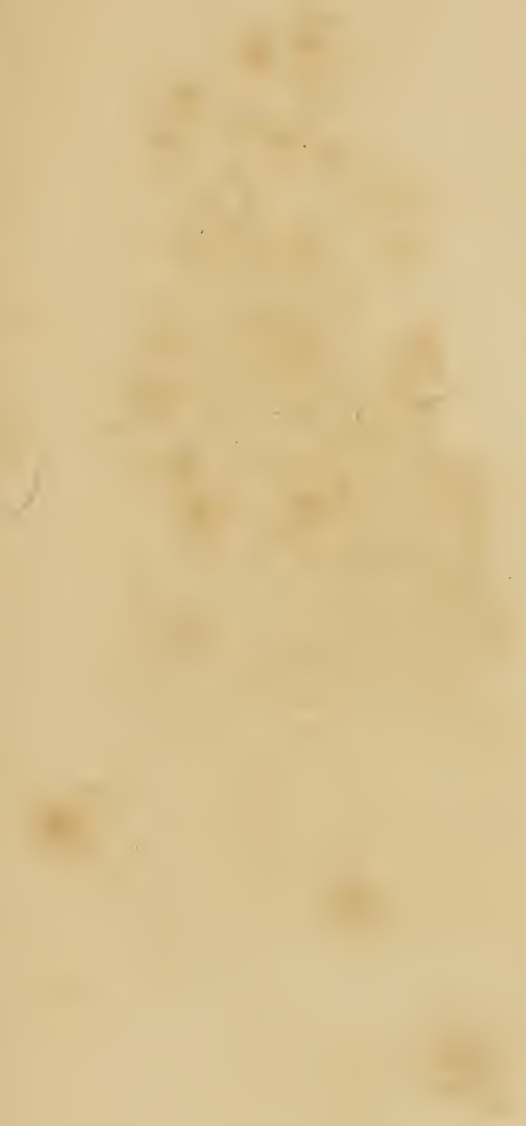


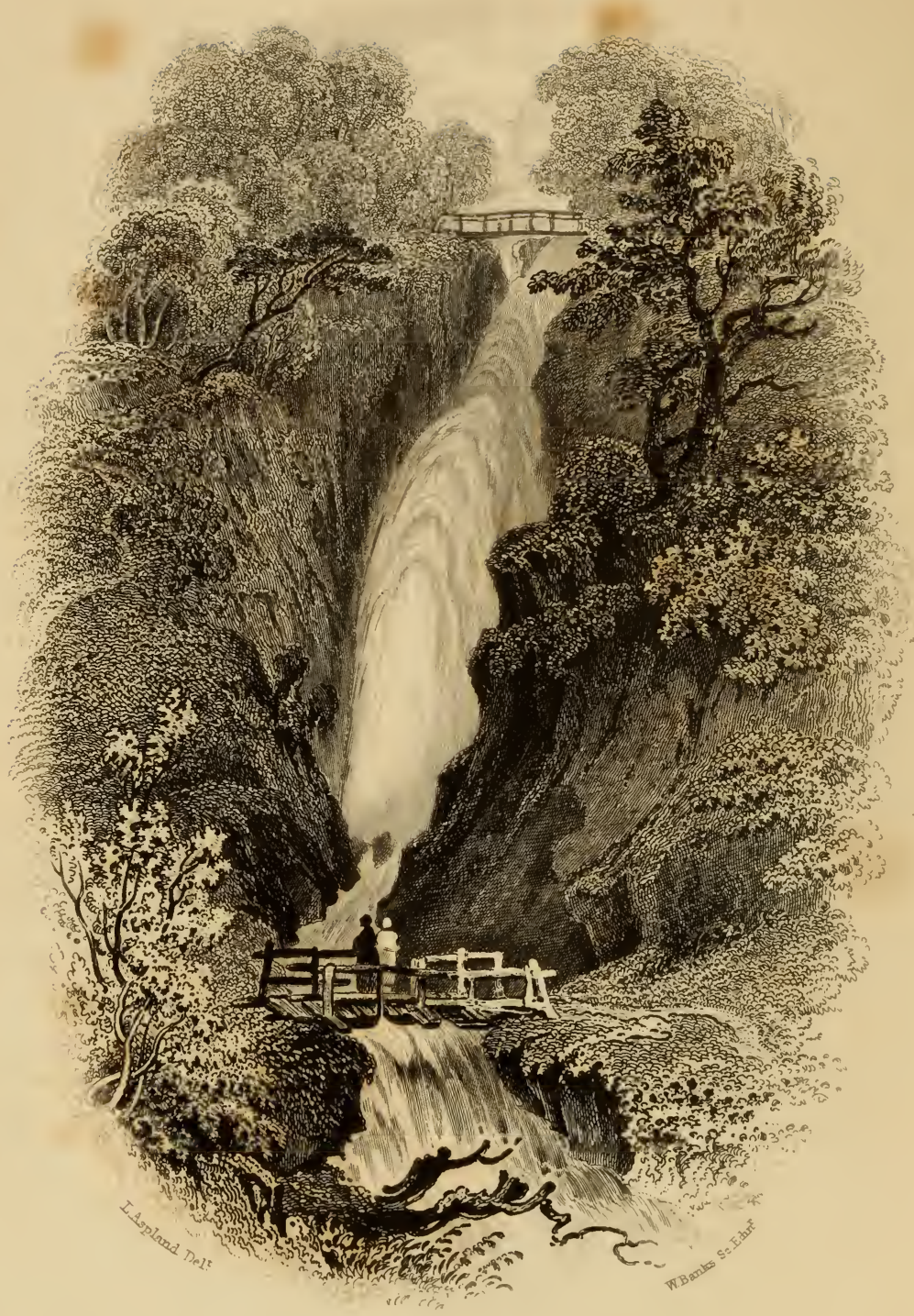




\section{(G) I] ] D) [F, \\ T(1) 『田 居}

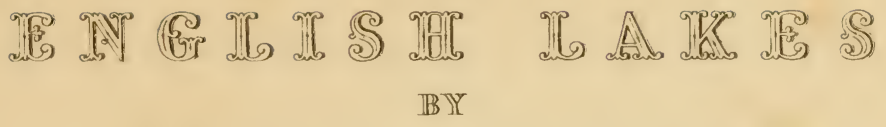

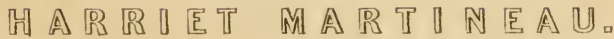
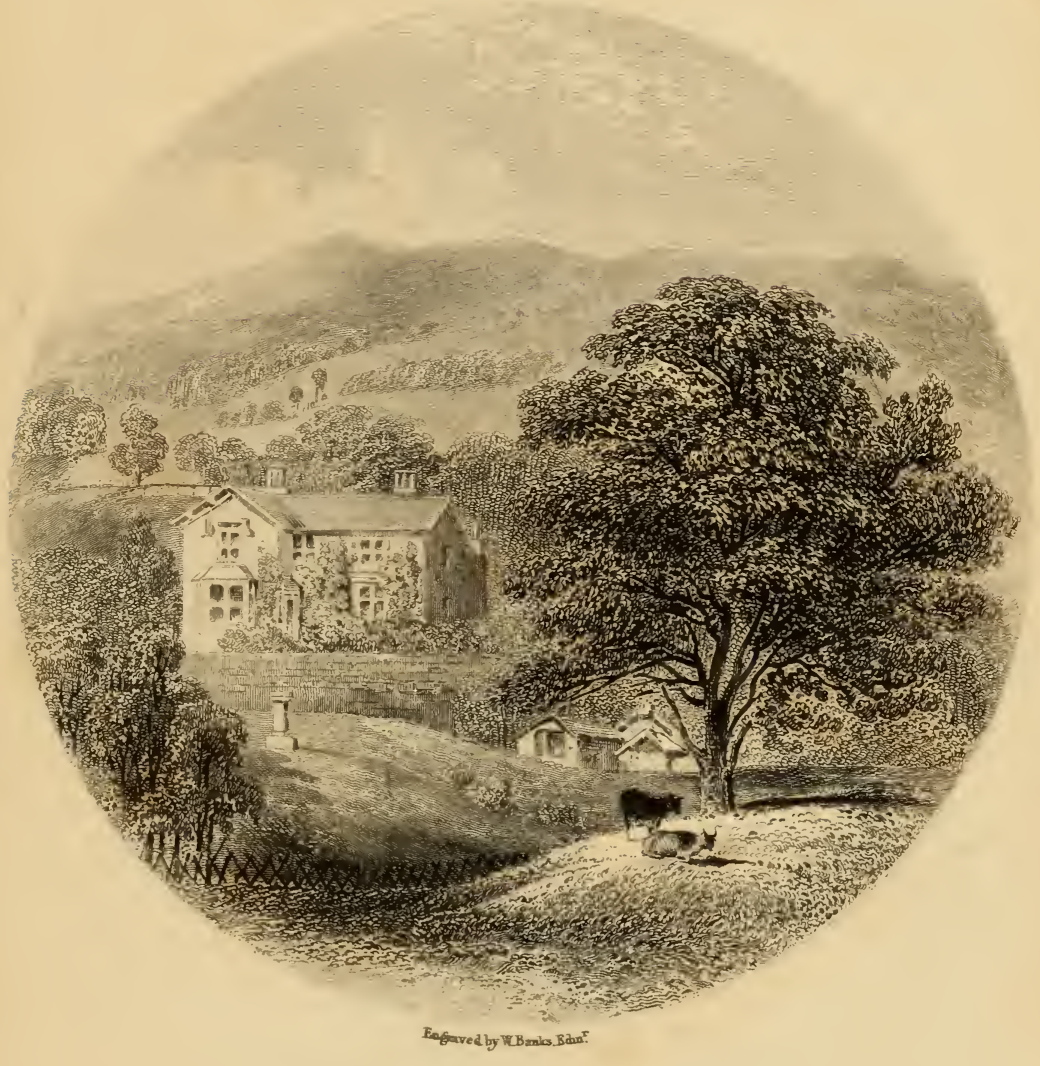

ethe efrnoll Ambleside, The residence of

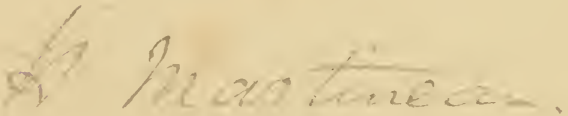

W I D F R M R E:- JOH N G A R ETT. 

A

\section{COMPLETE GUIDE}

TO THE

\section{ENGLISH LAKES, \\ ax}

\section{HARRIET MARTINEAU,}

ILLUSTRATED FROM DRAWINGS BY T. L. ASPLAND AND W. BANKS,

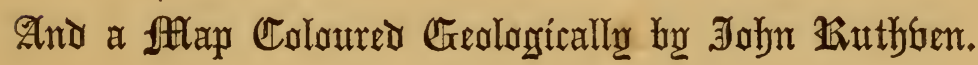

TO WHICH $\triangle R E$ ADDED AN ACCOUNT OF THE

FLOWERING PLANTS, FERNS, AND MOSSES OF THE DISTRICT,

AND A COMPLETE DIRECTORY.

WINDERMERE : - JOHN GARNETT.

LONDON : - WHITTAKER AND CO. 


$$
\text { RB D } D 670 . \mathrm{LIMH}
$$

Ace .95.450

WINDERMERE: PRINTED BY JOHN GARNETT. 


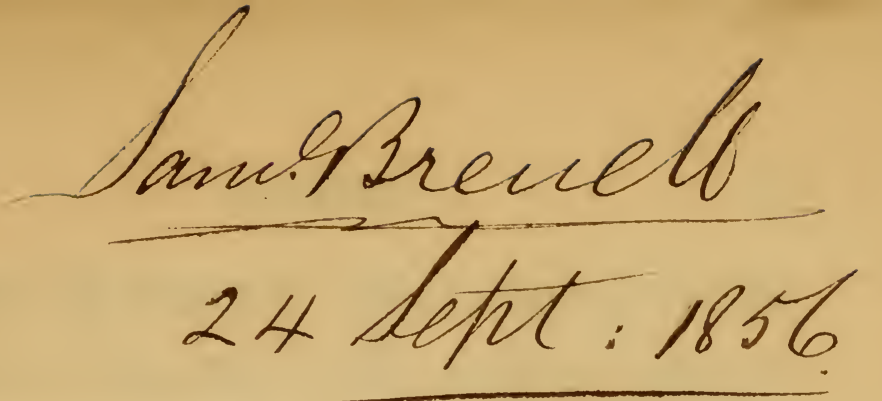

\section{PREFACE.}

The Knoll Aurbeside,

March 12th, 1855.

It is now some months since I committed the manuscript of this Lake Guide to the publisher's hands; and now that the work is just ready to appear, I am thankful to him for the opportunity of saying, in this prefatory page, with what pride and pleasure I have looked over the accessories and embellishments with which, by his zeal and spirit, and by the admirable cooperation he has been so fortunate as to secure, my humble work is elevated to a quality of real importance. 
When I look at Mr. Ruthren's valuable geological Map, Mr. Aspland's beautiful illustrative Views, so finely engraved by Mr. BANks; and, again, the Botanical contributions, so essential to the perfect understanding of the Lake District, it seems to me that the book has become, by all this aid, one which may not only be in every tourist's hands, but find a place on the library shelves of those who have never visited, and may not contemplate visiting, this district of England. At the same time, the Directories, (a new feature in a Guide Book) are likely to make it valuable to residents, who need no guide to the scenery near their homes. If my gratitude to my coadjutors causes me to overrate the product of our labours, I shall not at least be mistaken in saying that we have all done our best to set forth a true presentment of a land we love, in the hope of inducing and enabling those 
who live in town or plain to know and love it as we do. If any think that we have painted it too fair, and that we love it fanatically, let them come and see.

\section{H. MARTINEAU.}





\section{CONTENTS.}

\section{PART I.}

Page.

$\begin{array}{lllllllll}\text { WINDERMERE } & \ldots & \ldots & \ldots & \ldots & \ldots & 3\end{array}$

$\begin{array}{llllllll}\text { BownESS } & \ldots & \ldots & \ldots & \ldots & \ldots & 9\end{array}$

Walk by Cook's House $\quad \ldots \quad \ldots \quad \ldots \quad \ldots \quad 14$

$\begin{array}{lllll}\text { Steamboat Trip } & \ldots & \ldots & \ldots & 16\end{array}$

First Tour. To Furness Abbey and Coniston $\ldots{ }^{\ldots} \quad \ldots \quad 21$

Second Tour. To Patterdale and Ambleside ... 33

ThIRD Tour. To Skelwith and Grasmere $\quad \ldots \quad$.. 45

$\begin{array}{lllll}\text { A day on the Mountains ... } & \ldots & \ldots & \ldots & 57\end{array}$

\section{PART II.}

$\begin{array}{llllll}\text { To Keswick from Ambleside } & \ldots & \ldots & \ldots & \ldots & 67\end{array}$

$\begin{array}{lllll}\text { Excunsions from Keswick } & \ldots & \ldots & \ldots & 74\end{array}$

I. Derwent Water $\quad \ldots \quad \ldots \quad \ldots \quad \ldots 74$

II. By Watendlath to Borrowdale and back by

$\begin{array}{llllll}\text { Lodore } & \ldots & \ldots & \ldots & \ldots & 76\end{array}$

III. By Vale of Newlands to Scale Hill, and back $\begin{array}{lllll}\text { by Whinlatter } \quad \ldots & \ldots & & & \\ & & \end{array}$

IV. Circuit of Bassenthwaite $\quad \ldots \quad \quad \ldots \quad 88$

V. Ascent of Skiddaw $\quad \ldots \quad$... $\quad \ldots \quad 90$

VI. Ascent of Saddleback $\quad \ldots \quad$...

\section{PART III.}

CIRCUIT OF THE LAKE DISTRICT.

Finst Tour. From Keswick by Patterdale to Ambleside... 103 Second Tour. From Ambleside to Strands $\quad \ldots \quad 106$ 
Third Todr. From Strands and Wastwater to Scale Hill $\begin{array}{lllllll}\text { Inn } & \ldots & \ldots & \ldots & \ldots & \ldots & \ldots 118\end{array}$

Fodrth Tour. From Scale Hill to Keswick by Honister Crag ...

\section{PART IV.}

PASSES AND MOUNTAINS.

Langdale from Borrowdale, by the Stake Pass $\quad \ldots \quad 145$

$\begin{array}{lllllll}\text { Path to Easedale } & \ldots & \ldots & \ldots & \ldots & \ldots & 148\end{array}$

$\begin{array}{llllll}\text { Path to Esk Hause } & \ldots & \ldots & \ldots & \ldots & 150\end{array}$

Sty Head Pass, from Wastdale to Borrowdale $\ldots . \quad \ldots 152$

$\begin{array}{llllll}\text { Ascent of ScAWFELL } & \ldots & \ldots & \ldots & \ldots & 157\end{array}$

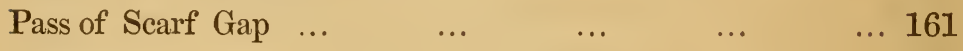

$\begin{array}{lllllll}\text { Grisedale } & \ldots & \ldots & \ldots & \ldots & \ldots & 163\end{array}$

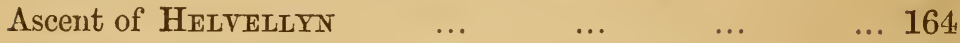

$\begin{array}{llllll}\text { Coniston OLd MAN } & \ldots & \ldots & \ldots & \ldots & 167\end{array}$

$\begin{array}{lllllll}\text { Walna Scar } & \ldots & \ldots & \ldots & \ldots & \ldots 167\end{array}$

$\begin{array}{lllllll}\text { Hawes Water ... } & \ldots & \ldots & \ldots & \ldots & 170\end{array}$

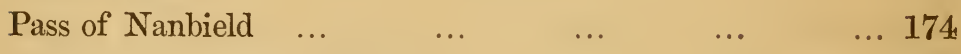

$\begin{array}{lllll}\text { Weather in the Lake District } \quad \ldots & \ldots & \ldots & 177\end{array}$

\section{PART V.}

FLOWERING PLANTS, FERNS, AND MOSSES.

Windermere and its Neighbourhood $\quad \ldots \quad \ldots \quad \ldots \quad \ldots 181$

$\begin{array}{llllllll}\text { Cumberland } & \ldots & \ldots & \ldots & \ldots & \ldots & \ldots & 192\end{array}$

\section{PART VI.}

DIRECTORY.

The postal address of the Aristocracy, Gentry and Tradespeople of the District. 


\section{INDEX.}

Adventure on Esk Hause 116

Ambleside 41, 46, 56, 213

$$
\text { Mill } 56
$$

Ancient Customs 138

Anecdote of Charcoal Burner 23

Angle Tarn 40, 105, 145

Applethwaite, Cumberland 93

Approach to Lakes 5

Outline of Mountains 93

Ara Force 39, 104, 180

Armboth Fells 69

$$
\text { View of, facing Titlepage }
$$

Atmospheric Changes 15, 50, 52

Barf (mountain) 89

Barrow House 76

" Fall 76, 180

Bassenthwaite Lake 71, 88, 180, 226

Beacon 15

Bewitched Cow 142

Birker Force 117, 180, 231

Bishop Watson 15

Biscut How 9

Black Cap (mountain) 145

Blackcombe 57 107, 179

Blacklead Mines $15 \tilde{5}$

Blacksail 161

" Adventures on 126

Blakeaberry Tarm 133

Blea Tarn 115, 147

Blea Water, High Street 173

Blelham Tarn 36

Blencathra (mountain) 96, 179

Boats, instructions about 20

Bobbin Mills 42, 47

Bowness 9, 209

, Parish Church 11

, Quay 11

, Rectory 11

Borrowdale 77, 135, 152, 227

$\begin{array}{cc}" & \text { Anecdotes o } \\ " & \text { Echoes } 82 \\ " & \text { Yews 156 } \\ \text { Hawes } 179 \\ \text { wder Stone 86 }\end{array}$

Bowder Stone 86:

, View of 152
Bowfell, 7, 48, 146, 179

Bowscale Tarn 101

Brackenthwaite 232

Braithwaite 87, 226

Brathay $19,44,46$

Bridal of Triermain 70

Brothers' Water 37. 180

Broughton Tower 107

Brougham Castle and Hall 171

Buttermere 86, 131, 180, 229

Hawes 179

Cairn" on Dummail Raise 68

Calder Abbey 122

, Bridge 122

Calgarth 43

Woods 15

Candlemas Settlements 140

Carrock Fell 179

Castle Crag 72, 81

Castlehead, Derwent 74

Castlehill, view from 77

Castlerigg, view from 71

Castle Rock 70

Cat Bells (mountain) 72, 179

Catchedecam 164

Causey Pike 179

Char and Trout 20, 32

Charges at Hotels 10

Charles Lamb on Skiddaw 93

Cheese (hard) 144

Christopher North 13, 60

Churning 142

Clappersgate 7, 15, 44

Climate 192

Cockley Beck 115

Codale Fell 149

Cold Fell 124

Coldfield (mountain) 37

Colouring of Foliage 12

Colwith Bridge and Force 114180

Cook's House 16, 33

Coniston Lake 26, 28, 167, 180, 217

, View of 28

" Old Man 7, 27, 58, 167, 179

Copper Mine 168

Craig 9

Croft Lodge 7 
Crosthwaite Church 71, 83

Crummock Water 84, 180

Outline of Mountains 84

Cuckoo in Borrowdale 78

Curwen's Island 12

Daffodils and Snowdrops 46

Dale Head 227

Dale Management 143

Deepdale 105

Deepening foot of Windermere Lake 17

Derwent Lake 71, 80

" View of 74

" River, 80, 89, 145

Devoke Water 169

Dove Nest 18

Drainage 18

Drinking 140

Druidical Remains 170

Druids' Temple 94

Dunmail Raise 68, 49

Legend of 94

Dunnerdale 232

Duddon 107

Dungeon Ghyll 48, 180

Eagles 153

Eagle Crag 145, 152

Easedale 'Tarn 51, 149

Ecclerigg 18

Egremont 124

Traditions of 125

\section{Elleray 7}

Elterwater Powder Mills 48

Ennerdale 125, 180, 230

Enviable Abode 15

Eskdale 111, 113, 231

Esk Hause 150

Esthwaite Water 29, 180

Fairfield 7, 58, 179

Falcon Crags 82

Fell Foot, Langdale 115

Ferry, Windermere 12, 13, 32

"Finest View in Westmorland" 48

Fishing 12

Flintof't's Model 72

Floating Island, Derwent 75

Foliage 13

Foxes 168

Fox How 41, 55

Furness Abbey 24

Gaitsgarth 133

Gaits Tarn 168

Ghost Stories of Souter Fell 97

Giant's Grave 17 !

Gillerthwaite 161

Glaramara 77

Glencoin 38

Glenderatera, river 102

Gowbarrow Park 37, 104
Gowder Crag 82

Grange, Borrowdale 81

Grasmere 49, 52, 137, 164, 180, 219

" View of 49

Grassmoor 85, 179

Great End 114

Great Gable 129, 145, 179

Great Robinson (mountain) 84

Greta Bank 102

" Hall, 83

„ River 92, 102

Grisedale 163

" Pike 179

" Tarn 163

Guides on Mountains 58, 90, 159

Hanging Knotts 145

Hardknot 117

Harrison Stickle (Langdale Pike) 147

Harter Fell 172

Hartley Coleridge 52

Hartsop 37, 105

Haunted House, anecdote of 69

Hawes Water 88, 180

Hawks and Buzzards 62

Hawkshead 29, 220

Hawlghyll 114, 118

Hays Water 40, 105

Hayrick (mountain) 84

Helm Crag (Lion and the Lamb) 49

Helvellyn 49, 179

Heronry 53 ascent of 163

Hesket Hawes 170

Highest inhabited House in England 36

Highstile 81;

High Street $7,34,105,172,174,179$

Hill Bell 7, 179

High Close 49, 147

High Crag 84

High Pike 179

Honister Crag 133, 179

Hotels", charges at 10

View of 133

Ibbotsholme 43

Irt, river 114

Keskadale 84

Kentmere 175

Keswick 72, 222

Kirkstone Pass 179

Kinniside 230

Kidsty Pike 172

Kirkfell 126

Knot Crag 102

Lakes, length, breadth, and depth of 180

Lamplugh Cross 130

Langdale 48, 114, 146, 217

Tarn 114

Lang'dale Pikes 7, 15, 46, 147, 179

Latrigg 92, 179 
Lead Mines 163

I/egberthwaite 70, 227

Legend of Ara Force 38

Levers Water 169

Lilly of the Valley 19

Ling Crag 85

Lingmell (mountain) 114, 119

Linthwaite Woods 86

Fell 100

Little" Langdale 148

Long Meg and her Daughters 170

Loughrigg, 7, 12, 46, 49, 58

Lord"Derwentwater 75

Lord's Island 75

Lord's Seat (mountain) 89, 179

Lorton 89

Lowdore Cascade 81, 180

Loweswater, 130, 180, 228

Low Man 92

Lowther Castle 172

Lowwater Tarn 168

Lowwood Hotel 18, 58

Lyulph's Tower 38

Mardale 36, 230

Measand 230

Mellfell 104

Middlefell 114

Milbeck, Keswick 93

, Langdale 147

Millbreak 85

Miller Brow (unsurpassed view) 15

Mists on Mountains 63

Miterdale 113

Mosedale 16, 120

Mosses and Ferns 189

Mountains, a Day on the 57

$$
\text { " height of } 179
$$

Museum, Armstrong's 10

Mrlnbeck 9

Crosthwaite's, Keswick 72

Nab Scar 53, 58, 64

Nag's Head, Wythburn 68

Nanbield 174

Native Genius 79

Need Fire 142

Netherwastdale 231

Newby Bridge 18, 21, 211

Newfield Church 109

Newland Hawes 84

Nook 58

Orrest Head 6

Ouse Bridge 89

Passes 105

Patterdale 37, 104, 163, 229

Pavey Ark 148

Peacock in Borrowdale 80

Peel Wyke 89

Penrith 170
Picturesque Farmsteads 32, 47

Pillar 161, 179

Place Fell 37, 105, 163

Portinscale 83, 225

Pretty Scenery 17

Priest among the Shepherds 62

Professor Wilson 13

Primitive farms 47

Provisions for Pedestrians 57

Pull Cottage 19

Pullwyke Bay 19

Railway to Windermere 4

Rain" Guages 62 in Lake District 5, 144

Rampsholm, Derwent 74

Rannersdale Knot 185

Raven Crag 27

Rayrigg 15, 18

Rectory, Windermere 11

Red Bank 49

Red Pike 84, 86, 179

Red Tarn 164, 180

Robert Walker, the wonderful 108

Roman Road 34, 174

Rosset Gill 150

Rosthwaite 77, 80

Rothay, river 19

Rotten Pulpit 147

Route to the Lakes 3

Ruins by Moonlight 26

Rydal Lake 50, 53, 180

, Mount 47, 54

" Falls 180

" Forrest 58

" Head 179

" Outline of Mountains 54

Santon Bridge 113

St. Cuthbert, anecdote of 74

St. Herbert, do 74

St. John's Church, Keswick 71

St. John's, vale of 70

St. Mary's College 8

Sawrey 30, 210

Scandale Screes 37

Scale Hill Inn 80, 131

„ Force 80, 85

Scales, village of 96

, Tarn 96

Scandale Beck 59

Scarf Gap 161

Scawfell 114, 119, 179

" ascent of 157

Scott, Sir Walter, anecdotes of $13,67,170$

Screes 114, 118

Seathwaite 109, 116, 232

Seatoller 135 Tarn 168

Seat Sandal 68, 164

Seclusion, effects of 76 
iv.

Smoking Lime 78

Sharp Edge 101

Shepherds' Crag 82

Shire Stones 115

Slate Quarries 48, 133

Skiddaw 71, 90, 179 ascent of 90

Skidadaw Forrest 92

view from 92

Skelwith Fold and Force 47

Solitude 51, 61

Sour Milk Ghyll Force 51, 133, 180

Southey 83

Spectral Mists 62

Sprinkling Tarn 20, 150

Squalls on Lakes 20

Stake 144

Stanley Ghyll 112, 180

Statesmen, condition of 139

Station House, Windermere Lake 30

Station, Scale Hill 86

Steamboat Trip 16

Steel Fell 68

Stepping Stones 111

Stickle Tarn 147, 148

Stockghyll Force 43, 180

Stockley Bridge 155

Stock, river 36,56

Stone Fences 15, 59

Stonethwaite 145

Storm on the Mountains 127

Striding Edge 163

Storrs 13

Stybarrow Crag 37

Sty Head 120, 152, 179

$$
\text { " Pass 114, } 152
$$

"Tarn 153

Styrups, getting out of 79

Superstitions 142

Swamps, fever and ague 18

Swan Inn, Grasmere 49

Swirrel Edge 164

Tarns, use of 148

Tempest on Mountains 62

Tent Lodge 28

The Knoll 55

The Lark 111

The Wood 9

Thirlmere or Leatheswater 69, 180

\section{INDEX.}

Thirlmere Outline of Mountains 69

Thornthwaite 89, 227

Threlkeld 70, 228

Tilberthwaite 169

Torver 107

Trout and Char 20, 32

Troutbeck 33, 176, 212

Ullswater $38,63,104,180$

" Outline of Mountains 104 View of 38

Ulpha, anecdote of manners 109, 232

Ulverstone 23

Vale of St. John 70, 227

Vicar's Isle, Derwent 74

Wall End 147

Wallowbarrow Crag 72, 75, 82

Walna Scar 167.

Wanlas How 19

Wansfell 41, 58

Wansfell Holme 19

Wastdale Head 119, I53, 230

, School 119

Rural customs 120

Wastwater 112, 118, 180

Watendlath 76

View of 118

Waterspout 131

Waterfalls 180

Weather 177

Weatherlam 115, 169

Whinlatter 87,89

Whitelees (mountain) 81, 85

Whiteside (mountain) 85

Windermere Lake 46, 54, 180

$$
\text { , Hotel } 8
$$

" Outline of Mountains 7

" Perfect view of $\mathbf{4 6}$

" View of, from near Low

Wood 19

, View of, from near Storrs 13

, Village of 8,207

Wordsworth's Grave 52 Garden 54

Wray C̈astle 7, 19, 15, 43

Wrynose 115

Wythburn 165, 69, 227

Yewbarrow 114, 119, 161

Yewdale 27, 169 


\section{LIST OF ILLUSTRATIONS.}

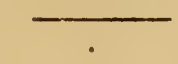

Ara Force, Gowbarrow Park... _ ... ... _.. $\quad$... title

Bowder Stone, Borrowdale

Coniston, from Bank Ground

Derwentwater, from Castle Head

Grasmere, from Red Bank ...

Honister Pass

Rydal Water ...

Ullswater, upper reach of

Vale of Keswick

152

Wastwater

...

Windermere, from near Lowwood

Storrs ...
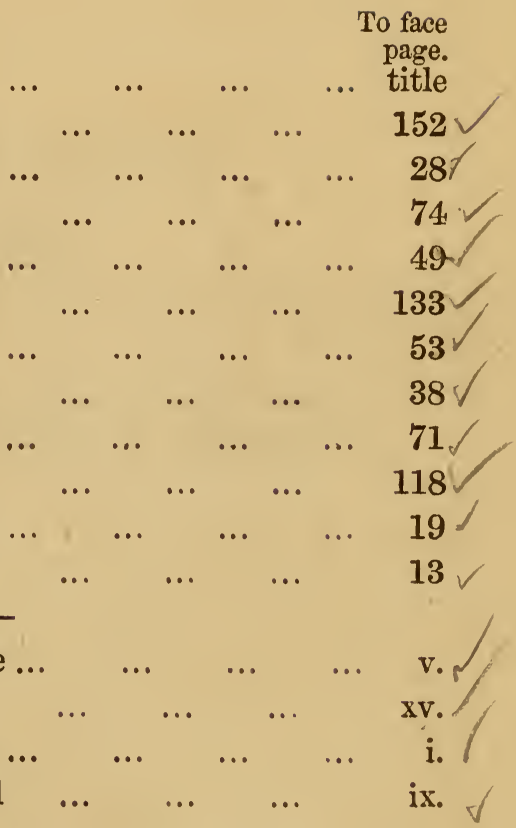

Royal Hotel, Bowness, Windermere

Waterhead Hotel, Coniston

Windermere, from near the Hotel

" from the Crown Hotel

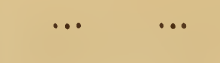




\section{ER R A T A}

Page 45, third line, for Easthwaite, read Easdale. Page 194, lines 12, 24, 31, for linchens, read lichens. 


\section{PART I. \\ W INDERMERE.}

A few years ago there was only one meaning to the word Windermere. It then meant a lake lying among mountains, and so secluded that it was some distinction even for the travelled man to have seen it. Now, there is a Windermere railway station, and a Windermere post-office and hotel; - a thriving village of Windermere and a populous locality. This implies that a great many people come to the spot; and the spot is so changed by their coming, and by other circumstances, that a new guide book is wanted; for there is much more to point out than there used to be; and what used to be pointed out now requires a wholly new description. Such new guidance and description we now propose to give.

The traveller arrives, we must suppose, by the railway from Kendal, having been dropped at the Oxenholme Junction by the London train from the south, or the Edinburgh and Carlisle train from the north. 
The railways skirt the lake district, but do not, and cannot, penetrate it: for the obvious reason that railways cannot traverse or pierce granite mountains or span broad lakes. If the time should ever come when iron roads will intersect the mountainous parts of Westmorland and Cumberland, that time is not yet; nor is in view, - loud as have been the lamentations of some residents, as if it were to happen to-morrow. No one who has ascended Dunmail Raise, or visited the head of Coniston Lake, or gone by Kirkstone to Patterdale, will for a moment imagine that any conceivable railway will carry strangers over those passes, for generations to come. It is a great thing that steam can convey travellers round the outskirts of the district, and up to its openings. This is now effectually done; and it is all that will be done by the steam locomotive during the lifetime of anybody yet born. The most important of the openings thus reached is that of WINDERMERE.

The mountain region of Cumberland and Westmorland has for its nucleus the cluster of tall mountains, of which Scawfell is the highest. There are the loftiest peaks and deepest valleys. These are surrounded by somewhat lower ridges and shallower vales; and these again by others, till the uplands are mere hills and the valleys scarcely sunk at all. It is into these exterior undulations that the railways penetrate; and, at the first ridge of any steepness, they must stop. It is this which decides the termination of the Windermere railroad, and which prevents the lateral railways from coming nearer than the outer base of the hills on the 
east and the coast on the west. When the traveller on foot or horseback sees certain reaches of Lake Windermere from Orrest Head, lying deep down below him, he knows he is coming near the end of the railway, which cannot yet plunge and climb as our old mail roads must do, if they exist here at all. As a general rule, lakes should be approached from the foot, that the ridges may rise, instead of sinking, before the observer's eye. But so happy is the access to Windermere from the station, that it is hard to say that it could have been better; and that access is, not from the south to its lower end, but from the south-east to about its middle. The old coach road over Orrest Head and the railway meet at the new village of Windermere, whence the road to Bowness descends, winding for about a mile and a half, striking the shore at a point rather more than half way up the lake, and commanding the group of mountains that cluster about its head.

Supposing that the traveller desires to see the Windermere scenery thoroughly, we shall divide our directions into portions ; first exhibiting what is to be seen in the immediate neighbourhood of the Windermere Hotel, or within a moderate walk; and then describing three tours, two of which may be easily taken in a day each. One mountain trip will be added, and, these being faithfully prosecuted, the tourist may be assured that he has seen all that falls within the scope of a summer visitor in the opening region of the Lake District.

A few minutes will take him to Orrest Head, where 
he will see a lovely view, - a picturesque cottage roof, surrounded by trees, in the foreground; grey rocks cropping out of the sward on the other side of the hedges; and in front, overlapping hills; range behind range, with the grey waters of the lake lying below. Already, a traveller who should remain any time in the district would find himself introduced to the humours of a remote region. Odd sayings and doings remain, and traditions of old singularities are not lost. This place, Orrest Head, was the residence of the noted Josiah Brown, who amused himself, a century ago, with welcoming beggars, whom he supplied with meat and lodging, - sometimes to the number of twenty in a night. He called them his "jolly companions;" and no doubt he got a world of amusement out of them, in return for his hopitality. The local saying, "that's too big a bo-o for a young horse," was Josiah Brown's, and it was originated thus. He was breaking in a young horse, when one of his men took a liberty, - such as his servants were always taking with him, - but in this case to be repented of. The fellow hid himself behind a gate-post, and yelled so tremendously as his master passed through that Josiah was thrown, and broke his leg. His good-natured criticism was, "that was too big a bo-o for a young horse;" and this is still the proverbial expression of extreme surprise.

The hill to the right is part of the Elleray property, so well known as the lake-home of Christopher North, and now so much improved by its present proprietor, Mr. Eastted. If the traveller should have the good fortune to obtain a ticket of leave to enter the 


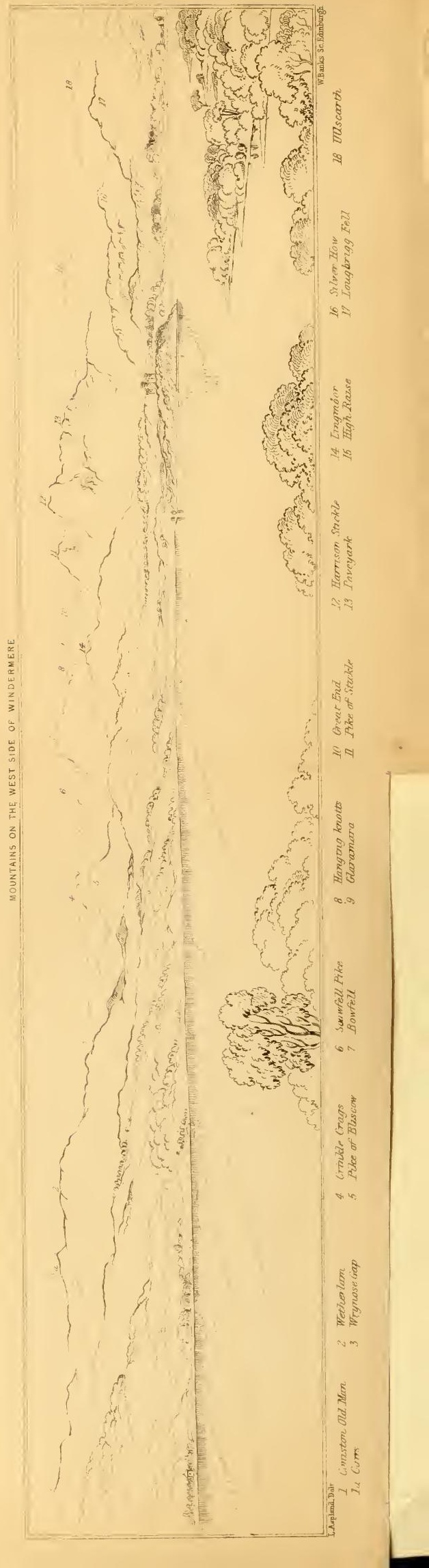


grounds, * his first object should be to walk up that hill at Elleray, by Mr. Eastted's new drive. All the way up, the views are exquisite : but that from the summit, - about 700 feet above the lake, is one of the finest the district can show. The whole length of Windermere extends below, with its enclosing hills and wooded islands; and towards the head, some of the highest peaks and ridges may be seen:-Coniston Old Man to the west; Bowfell and the Langdale Pikes to the northwest; Fairfield to the north, with Loughrigg lying, as a mere dark ridge, across the head of Windermere; while, to the north-east, Troutbeck is disclosed, with its peaks of High Street and Hill Bell. All below are woods, with houses peeping out; on a height of the opposite shore, Wray Castle; further north, the little Brathay Chapel, set down near the mouth of the valley; and between Loughrigg and the lake, at its head, the white houses of Clappersgate, with the chateau-like mansion of Croft Lodge conspicuous above the rest. This view is a good deal like

* A portion of the Elleray grounds are open to the public every Monday and Friday. Tickets of admission, bearing date, are issued on application to $\mathrm{Mr}$. Garnett, at the Windermere Postoffice, by paying a small donation, not less than one shilling, for a party of six persons, and, if above that number, the donation must be doubled. The proceeds are for the benefit of the school for the education of the poor, established by the Rev. J. A. Addison, and the sick and aged poor of Windermere, who may need assistance. - Parties will enter at the gate opposite the post-office, and proceed up the road to the right, which is the main road leading to the top of the hill, and return by the same route. All branch roads are strictly private. 
the one from the hill behind the Windermere Hotel, which is reached by a lane turning off from Orrest Head. The Elleray one is the most extensive and complete to the north : but to enjoy the other, leave will be readily obtained at the hotel.

The village of Windermere is like nothing that is to be seen any where else. The new buildings (and all are new) are of the dark grey stone of the region, and are for the most part of a mediæval style of architecture. The Rev. J. A. Addison, of Windermere, has a passion for ecclesiastical architecture; and his example has been a good deal followed. There is the little church of St. Mary, and there are the schools belonging to it, with their steep roofs of curiously-shaped slates: and there is St. Mary's Abbey, (new, in spite of its antique name), and St. Mary's Cottage. And there will be the new college of St. Mary, standing in a fine position, between the main road and the descent to the lake. This college, of which the Rev. J. A. Addison is the warden, is designed to afford a cheap and thorough education, on sound church principles, to the sons of clergymen chiefly, though not exclusively. It is under high patronage, ecclesiastical and local. The pupils, in a college garb of the olden time, are a curious feature in the aspect of the place; and they will be more so when they get their new buildings to live in. Judging by the plan and elevation put forth, the edifice will be in excellent taste, and a great adornment to the neighbourhood. The large house, on the hill and amidst the woods of the Elleray estate, and often mistaken for the new college, is the property of 
John Gandy, Esq., who has chosen a charming site for his abode; and a little further, on the same side of the road, is the pretty villa-residence of Miss Yates.

There are villas on either side the road, on almost every favourable spot, all the way to Bowness. The road past the college grounds leaves the other one to be called by the inevitable title of "the old road." We pass rows of lodging-houses; and then we see to the right the spot where the college is to be: and to the left Ellerthwaite, the residence of Mr. Geo. H. Gardner; and then, to the right, the cottage of Mylnbeck, the residence of the Misses Watson, daughters of the late bishop of Llandaff: a common house in its aspect towards the road, but, as seen over the wall, very pretty in its garden-front. The next gate on the left is the entrance to the Craig, built by Sir Thomas Pasley, and now inhabited by W. R. Greg, Esq. Below this, the houses begin to thicken about the entrance to Bowness. Among them, a road to the left leads to one of the most charming points of view in the neighbourhood, - a hill named Biscut How, crested with rocks, which afford as fine a station as the summit of Elleray for a view of the entire lake and its shores.

\section{BOWNESS}

Is the port of Windermere. There the new steamboats put up; and thence go forth the greater number of fishing and pleasure boats which adorn the lake. There is a good deal of bustle in the place; and the lower parts, near the water, are very hot in summer : and the more since the building of a new lodging house in a 
space near the church, which used to be called the lungs of Bowness. The two great inns, however, are in airy situations, - the garden platform of Ullock's Royal Hotel overlooking the gardens that slope down to the shore; and the Crown being on a hill which commands the whole place. These inns are both extremely well managed; and it is for the traveller to say whether their charges, which are uniform, justify a complaint which has been made, (we think unreasonably as regards the Lake District in general) of high prices. During the season, which extends from May to November, the charges are two shillings for breakfast, (including meat, fish, \&c.,) two shillings and sixpence for dinner; and one shilling and sixpence for tea. A private sittingroom is charged two shillings and sixpence per day. Ullock's Hotel, called Royal since the visit of Queen Adelaide in 1840, makes up between seventy and eighty beds. Close at hand is a little museum, where the birds of the district may be seen, exceedingly well stuffed and arranged by Mr. Armstrong, a waiter at the hotel. The Crown has ten private sitting rooms, and makes up ninety beds. Nothing can well exceed the beauty of the view from its garden seats.

There is an exhibition open in Bowness during the summer months, which, it will be useful, and particularly agreeable to the stranger to visit, before he penetrates further into the district. Mr. and Mrs. Lindsey Aspland exhibit their paintings of lake scenery every summer; and their pictures are of a high order of merit as works of art, as well as for their fidelity as portraits of scenery. Mr. Aspland's outline sketches are excel- 
lent ; and those on which the passes are clearly indicated are of especial value to the pedestrian tourist.

The old churchyard of Bowness, with its dark yews, and the weather-worn church, long and low, is the most venerable object in the place. The chancel window of the church contains painted glass from Furness Abbey. The tomb of Bishop Watson will be found in the churchyard, near the east window. The rectory, which is hardly less venerable than the church, stands at a considerable distance from the village, and is approached through fields and a garden. The oldfashioned porch is there, of which this is said to be the last remaining instance in the whole district, - the roomy, substantial porch, with benches on each side, long enough to hold a little company of parishioners, and a round ivy-clad chimney immediately surmounting the porch. Within, there is abundant space, with little elevation;-plenty of room in the hall and parlours, with ceilings that one can touch with the hand. Almost every other noticeable edifice in Bowness is new, or at least modern; the schools, the gift of the late Mr. Bolton, of Storrs Hall, - the Italian villa, called Belsfield, the property of the Baroness de Sternberg, and many others.

The visitor will first repair to the strand, to salute the waters. He will find a good quay, with boats in abundance, and several boat-houses within view. A substantial little pier is built out into the lake; and on either side is a steamboat moored during winter; and to the end these two steamers come, six times a day each, during the summer. To the right, gardens 
slope down to this little bay; and they look gay even in winter from their profusion of evergreens, and from the ivy which clothes their walls. The church just peeps out behind the houses above. Looking over the lake, Curwen's Island is just opposite. In May and early June, the woods of that island, and of all the promontories round, present a most diversified foliage, - from the golden tufts of the oak to the sombre hue of the pines, with every gradation of green between. In July and August, the woods are what some call too green, - massy and impenetrable, - casting deep shadows on the sward and the waters. Within the shadow on the shore stands the angler, watching the dimpling of the surface, as the fly touches it, or the fish leaps from it : and within the shadow on the water, the boat swings idly with the current; and the student, come hither for recreation, reads or sleeps as he reclines, waiting for the cool of the afternoon. Turning to the north, the highest peaks are not seen from this strand; but Fairfield and Loughrigg close in the head of the lake.

Turning southwards along the margin, and walking about a mile, the explorer reaches the point of the promontory, Ferry Nab, which stretches out opposite the Ferry House, - itself on the point of an opposite promontory. There can hardly be a more charming resting-place than a seat under the last trees of this projection. It is breezy here; and the waters smack the shore cheerily. The Troutbeck hills come into view, and the head of the lake is grander. The round house on Curwen's island is seen among the trees. The 



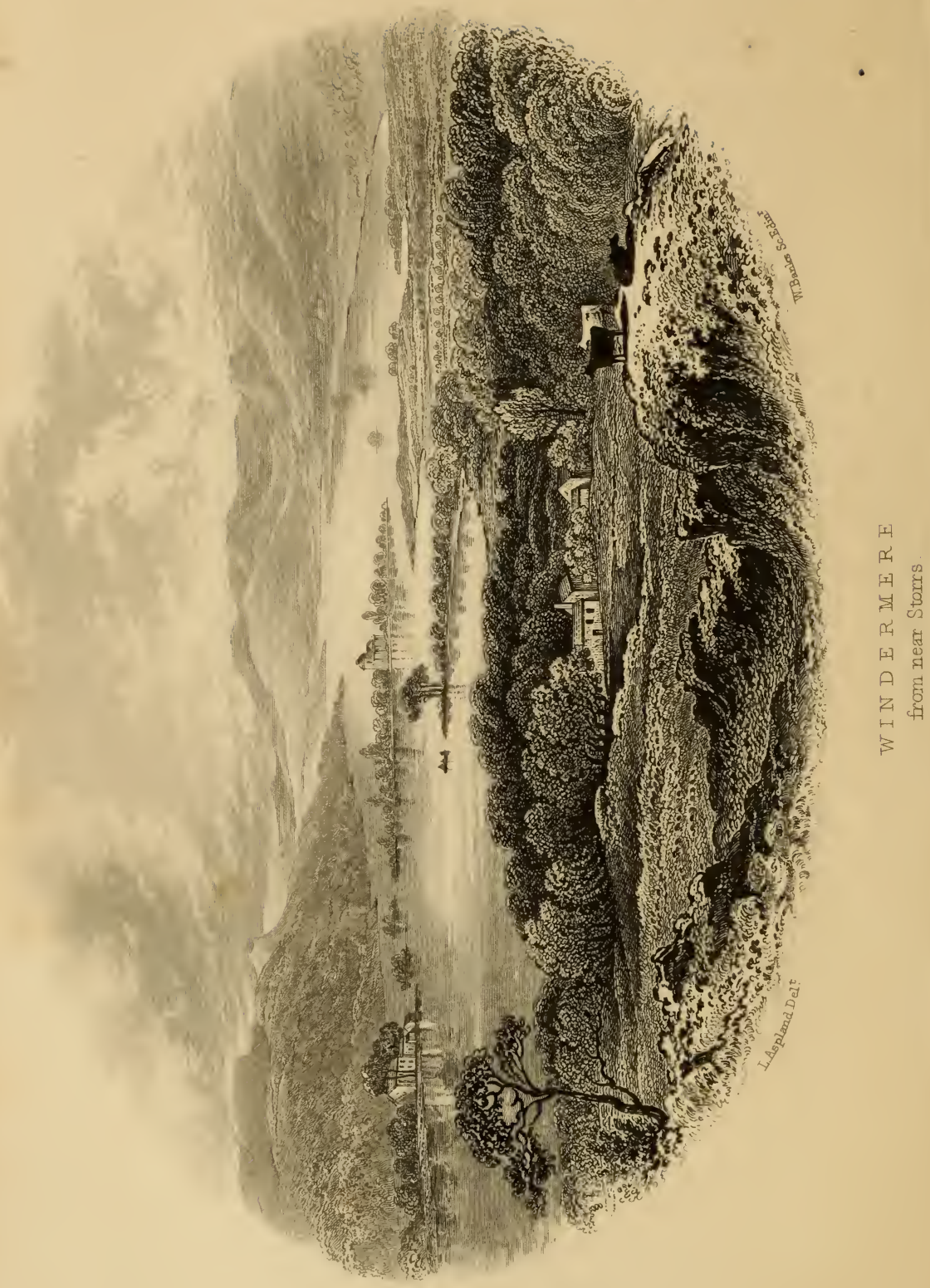


Ferry house, under its canopy of tall sycamores, and with its pebbly beach, is immediately opposite; and behind it rises the wooded bank which is, in light or shadow; one of the chief graces of the scene. If the sun shines upon it, it is feathered with foliage to the very ridge, and the bay beneath it is blue and lustrous. If the sun has gone down behind it, the bay is black; and every dipping bird sprinkles it with silver; and the wild duck that comes sailing out with her brood, draws behind her a pencil of white light. From this point, a view opens to the south. In the expanse of waters lies another island; and further down, on the eastern shore, a pier extends with a little tower at the end. This is Storrs : and at that pier did the guests embark when Scott went to meet Canning at Mr. Bolton's, and the fine regatta took place, (under the direction of Christopher North) which is celebrated in Lockhart's Life of Scott. This was only two years before Canning's death, and seven before that of Scott. Mr. and Mrs. Bolton are gone; and Christopher North himself has followed. It is probable that no stranger ever sees that pier at Storrs without thinking of Professor Wilson; and, indeed, there is no spot in the neighbourhood with which his memory, and the gratitude of his readers, is not associated. Any where, such a presence is rarely seen; and it was especially impressive in the places he best loved to haunt. More than one person has said that Wilson reminded them of the first man, Adam; so full was his large frame of vitality, force and sentience. His tread seemed to shake the ground, and his glance to pierce through stone walls; and, as for his 
voice, there was no heart that could stand before it. In his hour of emotion, he swept away all hearts, whithersoever he would. No less striking was it to see him in a mood of repose, as he was seen when steering the packet-boat that used to pass between Bowness and Ambleside, before the steamers were put upon the lake. Sitting motionless, with his hand upon the rudder, in the presence of journeymen and market-women, and his eye apparently looking beyond everything into nothing, and his mouth closed above his beard, as if he meant never to speak again, he was quite as impressive and immortal an image as he could have been to the students of his moral philosophy class, or the comrades of his jovial hours. He was known, and with reverence and affection, beside the trout-stream and the mountain tarn, and, amidst the damp gloom of Elleray, where he could not bring himself to let a tree or a sprig be lopped that his wife had loved. Every old boatman and young angler, every hoary shepherd and primitive dame among the hills of the district, knew him and enjoyed his presence. He made others happy by being so intensely happy himself, when his brighter moods were on him; and when he was mournful, no one desired to be gay. He is gone with his joy and his grief; and the region is so much the darker in a thousand eyes.

Instead of returning to his inn the way he came, the stranger may make a moderate and pleasant walk by going through Bowness on the Ambleside road, and round by Cook's House. The first noticeable abode that he will see is Rayrigg, - a rather low, rambling, grey house, standing on the grass near a little bay of 
the lake. It is a charming old-fashioned house, and its position has every advantage, except that it stands too low. On the high wall by the road side, immediately before reaching the gate of Rayrigg, the stranger will be struck with the variety of ferns. That wall is an excellent introduction to the stone fences of the region, richly adorned as many of them are with mosses and ferns.

Passing between woods, resounding with brawling streams, the road leads up a rather steep ascent, the summit of which is called Miller Brow. Hence is seen what, in our opinion, is a view unsurpassed for beauty in the whole Lake District. The entire lake lies below, the white houses of Clappersgate being distinctly visible at the north end and the Beacon at the south : and the diversity of the framework of this sheet of water is here most striking. The Calgarth woods, for which we are indebted to Bishop Watson, rising and falling, spreading and contracting below, with green undulating meadows interposed, are a perfect treat to the eye; and so are the islands clustering in the centre of the lake. Wray Castle stands forth well above the promontory opposite; and at the head, the Langdale Pikes, and their surrounding mountains seem, in some states of the atmosphere, to approach and overshadow the waters; and in others to retire, and shroud themselves in soft haze and delicate hues peculiar to cloud land. There is a new house, built just below the ridge at Miller Brow by William Sheldon, which we have thought, from the time the foundation was laid, the most enviable abode in the country, - commanding a 
view worthy of a mountain top, while sheltered by hill and wood, and with the main road so close at hand that the conveniences of life are as procurable as in a street. A short descent hence brings the walker to Cook's House, - the point where four roads meet. Cook's house has only just disappeared. With it has disappeared a fine specimen of the old fireplace of the district, with its chimney-corners. It is rather a drawback to the romance hanging about those wide old chimnies, to know that the good man had to sit with some special covering over his head and shoulders, to protect him from the soot that the rain brought down. At Cook's house there were recesses and cupboards in that strange roofless alcove, - the door being of the old oak of which such fine specimens may be seen in the farm-houses of the dales. We should rather say, might till lately have been seen; for we fear there are but few left. The greater number of old chests, cupboard doors, and high backed chairs, covered with carvings, have found their way to the London curiosity shops, whence agents have been sent through the wildest places in the district to buy up such relics at high prices. Still, there are specimens left, as the observant traveller will notice.

Of the four roads which meet here, the one to his left would take him to Ambleside; the one opposite, to Troutbeck. To reach his inn he must take the one to the right, which leads him straight home.

The next thing to be done is to take a survey of the whole lake by a steamboat trip. During the summer, two steamers make six trips each; so that the stranger can choose his own hour, and go down or up first, as he 
pleases. In accordance with the rule of lake approach, we should recommend his going down first. He embarks at the pier at Bowness, and is carried straight across to the Ferry, where the boats touch. Then the course is southwards, with the lake narrowing, and the hills sinking till the scenery becomes merely pretty. The water is very shallow towards the foot, and the practicable channel is marked out by posts. The best work that the whole neighbourhood could undertake would be the deepening of the lake at this part, and of the river which carries off the overflow. Not only is the passage of the steamers difficult : there is a far worse evil in the inundations which take place on all the lowlying lands, even up to Rydal, from the insufficiency of the outlet. The mischief has much increased since drainage has been introduced. The excellent and indispensable practice of land drainage must be followed up by an improvement in arterial drainage, or floods are inevitable. The water which formerly dribbled away in the course of many days, or even weeks, now gushes out from the drains all at once; and if the main outlets are not enlarged in proportion, the waters are thrown back upon the land. This is the case now in the neighbourhood of Windermere, - the meadows and low-lying houses at Ambleside, a mile or two from the lake, being flooded every winter by the overflow of the lake first, then of the river, then of the tributary streams. The Steam Yacht Companies gave fifty pounds to have the lake deepened at Fell Foot, about five years ago ; and Mr. White, the proprietor of the Newby Bridge Hotel, subscribed the same amount: and this was good as far 
as it went. But a much larger operation is required. There is a weir below Newby Bridge, to serve a corn mill. Now, the days of weirs and watermills are coming to an end. In these days of steam engines it is not to be endured that hundreds of acres should be turned into swamps, and hundreds of lives lost by fever, ague, and rheumatism, for the sake of a waterpower, which pays perhaps thirty pounds or forty pounds a-year. We say this of watermills generally; and in regard to the need of sufficient arterial drainage, we speak of the shores of Windermere in particular. The expense of carrying off the utmost surplus of the waters in the wettest season would be presently repaid, here as anywhere else, by the improved value of the land and house property, relieved from the nuisance of flood.

The Swan Inn at Newby Bridge is exceedingly comfortable; and the charges are very moderate. The stranger will have to come again, on his way to Furness, at all events, and perhaps in some trip to Hawkshead; or when making the circuit of the lake by land. Now, he merely calls for lunch or tea, during the stopping of the steamer; and then he is off again, up the lake. After the Ferry and Bowness, the next call is at Lowwood inn, where there are sure to be passengers landing or embarking. Between Bowness and Lowwood inn, Rayrigg has been seen, beside the little bay; and then Ecclerigg, with its overshadowing trees, and pretty pier. It is inhabited by Richard Luther Watson, Esq., grandson of the late Bishop of Llandaff. Just above Lowrood, high up on the wooded side of Wansfell, will be seen Dove Nest, once the abode of Mrs. 



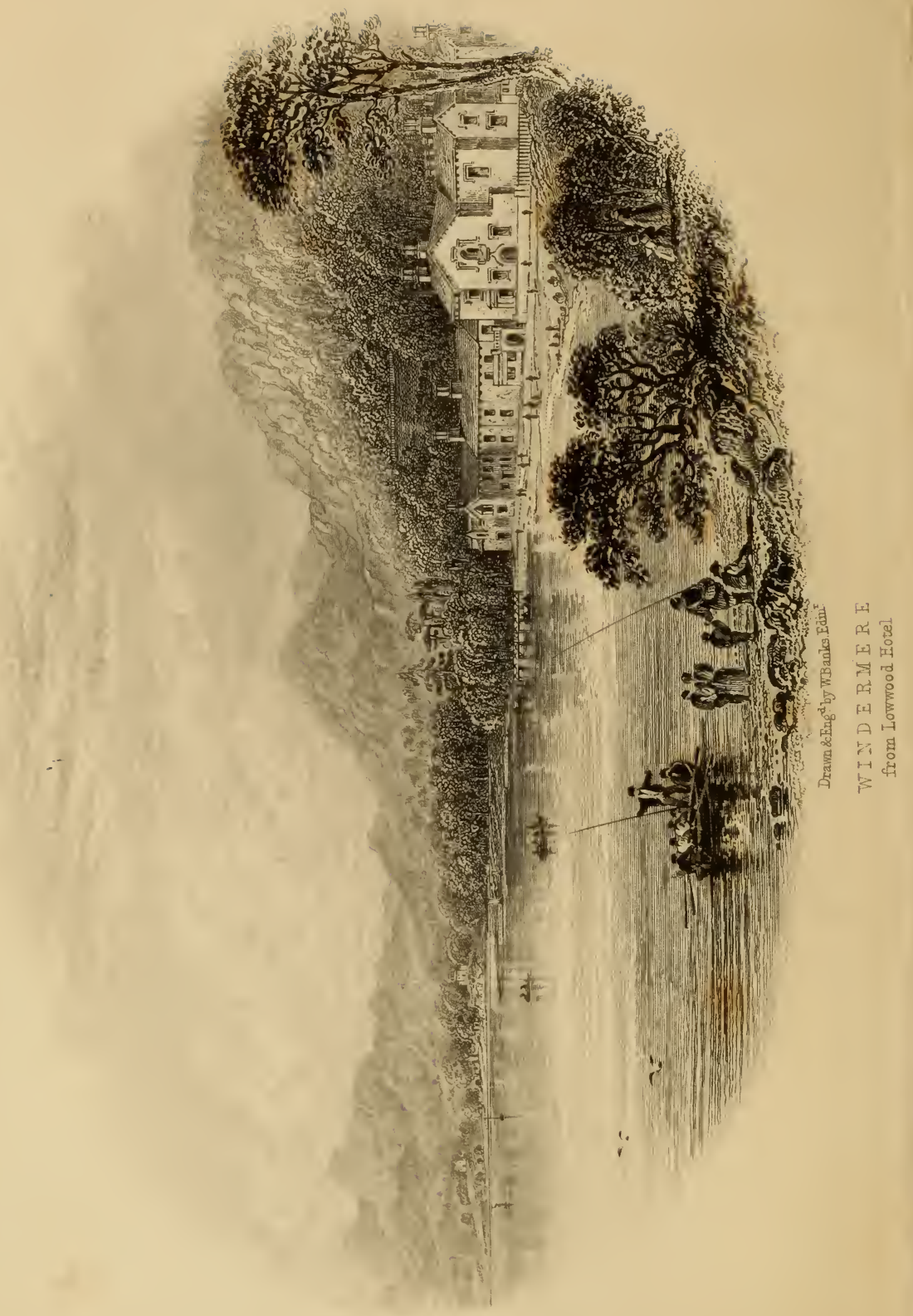


Hemans, when its appearance was more primitive and less pretty than it is now, - improved as it has been by its present resident, her then young friend, the Rev. Robert Perceval Graves. Next comes Wansfell Holme, inhabited by the Rev. James J. Hornby. 'This is another choice situation. On the opposite shore is Wray Castle, erected by James Dawson, Esq., - - most defensible-looking place for so peaceful a region; but an enviable residence, both from its interior beauty and the views it commands. Just above it, Pullwyke bay, where lily of the valley is found, runs far into the land; and overlooking it is seen Pull Cottage, the residence of Major Rogers. Next, the sweet, tranquil Brathay valley opens, with Mr. Redmayne's mansion of Brathay Hall, on a green slope above the lake; and just behind, on a wooded knoll in the gorge of the valley, the beautiful little church, called Brathay Chapel, built by Mr. Redmayne.

Two rivers fall into the lake, uniting just before they reach it; - the Rothay, which comes down from Dunmail Raise, beyond Grasmere, and the Brathay, which issues from Elterwater, a group of pools, rather than a lake, lying at the foot of the hills near Langdale. The valleys of the Rothay and the Brathay are separated by Loughrigg, - the ridge of which, at its further end, commands Grasmere ; its Windermere end shelters Clappersgate and Waterhead. The steamer sweeps round to the pier at Waterhead, where there is a cluster of dwellings, the most imposing of which is the large grey stone house called Wanlas How, the property of Alexander C. Brenchley, Esq. Omnibuses are in waiting here, from Ambleside and Grasmere, - 
the one, distant one mile; and the other, between four and five. Our tourist will, however, complete the circuit of the lake, by returning to Bowness.

There are plenty of boats to be had at.Waterhead and Bowness, and watermen who are practised and skilful. The stranger should be warned, however, against two dangers which it is rash to encounter. Nothing should induce him to sail on Windermere, or on any lake surrounded by mountains. There is no calculating on, or accounting for, the gusts that come down between the hills; and no skill and practice obtained by boating on rivers or the waters of a flat country are any sure protection here. And nothing should induce him to go out in one of the little skiffs which are too easily attainable and too tempting, from the ease of rowing them. The surface may become rough at any minute, and those skiffs are unsafe in all states of the water but the calmest. The long list of deaths occasioned in this way, - deaths both of residents and strangers, - should have put an end to the use of these light skiffs, long ago. The larger boats are safe enough, and most skilfully managed by their rowers : and the stranger can enjoy no better treat than gliding along, for hours of the summer day, peeping into the coves and bays, coasting the islands, and lying cool in the shadows of the woods. The clearness of the water is a common surprise to the resident in a level country; and it is pleasant sport to watch the movements of the fish, darting, basking, or leaping in the sunshine, or quivering their fins in the reflected ray. What the quality of the trout and char is, the tourist will probably find every day, at breakfast and dinner. 


\section{FIRST TOUR.}

FROM BOWNESS, BY NEWBY BRIDGE AND ULVERSTONE TO FURNESS ABBEY, RETURNING BY CONISTON, HAWKSHEAD, AND THE FERRY.

\begin{tabular}{|c|c|c|c|c|c|c|c|c|}
\hline MIL] & & & & & & & & MILES \\
\hline & Bowness to & Newby Bridge & e ... & & $\cdots$ & & $\cdots$ & 8 \\
\hline 8 & Ulverstone & $\ldots$ & & ... & & ... & & 16 \\
\hline 7 & Furness & & $\ldots$ & & $\ldots$ & & $\ldots$ & 23 \\
\hline 8 & Foot of Coni & iston Water ... & & $\ldots$ & & $\ldots$ & & 31 \\
\hline 7 & New Inn & $\ldots$ & , & & $\cdots$ & & $\ldots$ & 38 \\
\hline 4 & Hawkshead & $\ldots$ & & ... & & $\cdots$ & & 42 \\
\hline 3 & The Ferry & ... & $\ldots$ & & $\ldots$ & & $\ldots$ & 45 \\
\hline
\end{tabular}

For the greater convenience of taking his pleasure on the water, the traveller will now shift his quarters to Bowness, where he will find himself, as we have said, comfortably accommodated at either Ullock's Royal Hotel or the Crown. Now is his time for visiting Furness Abbey. This should be the first of his tours, because it will lead him into the least mountainous parts of the district.

He will go down to Newby Bridge either by steamer, or by the road, which passes the grounds of Storrs, and cuts over hill and dale, and winds among the copses, till it crosses the bridge opposite the inn. Those copses have been valuable to the remotest known date, for charcoal, and they have become more so since the increase of manufactures has stimulated the demand for bobbins. There are bobbin-mills at Skelwith, at Amble- 
side, at Troutbeck Bridge, and at Staveley. But the charcoal-burning goes on still, we believe, with some activity in these southern parts of the district. The one the traveller has just passed was the scene of the life of two brothers whose name and fame will not be let die. Their name was Dodgson; and they lived in Cartmel Fell above a century ago. They were so intent on their wood-cutting that they spent Sunday in cooking their food for the whole week. They ate little but oatmeal porridge ; and, when that fell short, they tried Friar Tuck's ostensible diet of dried peas and hard beans. As they grew old, they began to feel the need of domestic help. Said the one to the other, "Thou mun out and tait a wife." — "Yes!" was the reply; "if thear be a hard job, thou olus sets yan tult." The thing was accomplished, however; and when the old fellows were still chopping away at upwards of eighty, rain or shine, ill or well, there was the wife in the dwelling, and children to help. The brothers left considerable property; but it went the way of miser's money; and there are no Dodgson's now in Cartmel Fell.

All the way to Furness, there are specimens of roads and lanes which are locally called Ore gates (ways,) from their being constructed from the slag and refuse of the iron-ore formerly brought into the peninsula to be smelted, on account of the abundance of charcoal there. There are few objects more picturesque, to this day, than the huts of the woodcutters, who remain on a particular spot till their work is done. Upon piled. stems of trees heather is heaped, to make a shaggy 
thatch; and when the smoke is oozing out, thin and blue, from the hole in the centre, or the children are about the fire in front, where the great pot is boiling, the sketcher cannot but stop and dash down the scene in his book. The children will say he is "spying fancies," - as they say of every one who sketches, botanizes, or in any way explores; and perhaps somebody may have the good taste to advise him to come at night, when the glow from the fires makes the thicket a scene of singular wildness and charm. A sad story about a charcoal-burner belongs to this neighbourhood. On two farms lived families which were about to be connected by marriage. The young lover was a "coaler," - a charcoal-burner; and one stormy day, when he was watching his fire, and sitting on a stone near his hut to take his dinner, he was struck dead by lightning. The poor crazed survivor, his Kitty Dawson, went to that hut after the funeral, and would never leave it again. She did nothing but sit on that stone, or call his name through the wood. She was well cared for. There was always food in the hut, and some kind eye daily on the watch, - though with care not to intrude. One day in winter, some sportsmen who were passing took the opportunity of leaving some provision in the hut. They became silent, and silenced their dogs. But she could never more be disturbed. They found her dead.

It is eight miles hence to the cheerful little town of Ulverstone, which is now reached by the railway from Whitehaven; and from Ulverstone, the railway stretches south, past Furness Abbey, to the 
margin of the sea. From Ulverstone to Furness, it is only seven miles. There is a good inn, - (though not cheap, as cheapness is not to be expected in the precincts of secluded ruins:) and here the tourist should bespeak his bed, if he means to study the Abbey.

The Abbey was founded in A. D. 1127. Its domains extended over the whole promontory in which it lies, and to the north, as far as the Shire Stones on Wrynose. They occupied the space between Windermere on the east and the Duddon on the west. The Abbot was a sort of king; and his abbey was enriched, not only by King Stephen, but by the gifts of neighbouring proprietors, who were glad to avail themselves, not only of its religious privileges, but of its military powers for the defence of their estates against border foes, and the outlaws of the mountains, - the descendants of the conquered Saxons, who inherited their fathers' vengeance. The Abbey was first peopled from Normandy, - a sufficient number of Benedictine monks coming over from the monastery of Savigny to establish this house in honour of St. Marye of Furnesse. In a few years their profession changed: they followed St. Bernard, and wore the white cassock, caul and scapulary, instead of the dress of the grey monks. It is strange now to see the railway traversing those woods where these grey-robed foreigners used to pass hither and thither, on their holy errands to the depressed and angry native Saxons dwelling round about. The situation of the Abbey, as is usual with religious houses, is fine. It stands in the depth of a glen, with a stream 
flowing by, - the sides of the glen being clothed with wood. A beacon once belonged to it; a watch tower on an eminence accessible from the abbey, whose signalfire was visible all over Low Furness, when assistance was required, or foes were expected. The building is of the pale red stone of the district. It must formerly have almost filled the glen: and the ruins give an impression; to this day, of the establishment having been worthy of the zeal of its founder, King Stephen, and the extent of its endowments, which were princely. The boundary-wall of the precincts inclosed a space of sixty-five acres, over which are scattered remains that have, within our own time, been interpreted to be those of the mill, the granary, the fish-ponds, the ovens and kilns, and other offices. As for the architecture, the heavy shaft is found alternating with the clustered pillar, and the round Norman with the pointed Gothic arch. The masonry is so good that the remains are, even now, firm and massive; and the winding staircases within the walls are still in good condition in many places. The nobleness of the edifice consisted in its extent and proportions; for the stone would not bear the execution of any very elaborate ornament. The crowned heads of Stephen and his Queen Maude are seen outside the window of the Abbey, and are among the most interesting of the remains. It is all triste and silent now. The chapter-house, where so many grave councils were held, is open to the babbling winds. Where the abbot and his train swept past in religious procession, over inscribed pavements, echoing to the tread, the stranger now wades among tall ferns 
and knotted grasses, stumbling over stones fallen from the place of honour. No swelling anthems are heard there now, or penitential psalms; but only the voice of birds, winds, and waters. But this blank is what the stranger comes for. Knowing what a territory the Abbots of Furness ruled over, like a kingdom, it is well to come hither to look how it is with that old palace and mitre, and to take one more warning of how Time shatters thrones, and dominations and powers, and causes the glories of the world to pass away.

The stranger will be among the ruins late, by moon or by star light; and again in the morning, before the dew is off, and when the hidden violet perfumes the area where the censer once was swung, and where the pillars cast long shadows on the sward. But he must not linger; for he has a good circuit to make before night.

The lake of Coniston, which is his next object, is in the district between Windermere and the Duddon, which has already been mentioned as formerly belonging to Furness Abbey. From Ulverstone, his road commands the estuary of the Leven for a few miles, and then approaches the foot of Coniston Water, which it reaches at eight miles from Ulverstone. Seven miles more bring him to the New Inn at Coniston, which, built under the direction of Mr. and Mrs. J. G. Marshall, is one of the most comfortable hotels in England. This lake, like Windermere, is flanked by low hills at the south end, and inclosed by magnificent mountains at the head, where Mr. J. G. Marshall's house and lands are more gloriously situated than almost any other in 
the region. The little town of Church Coniston, and the New Inn, are a mile short of Waterhead; and the stranger must stop, and look through the place, while his early dinner is preparing. The Old Man, eleventh in height of the mountains of the district, (2,576 feet) towers above him; and the abodes of the people will shew him that he is in the neighbourhood of a copper mine. There is one, some way up the mountain; and he may see the winding road up to it. Higher up, where there is an evident hollow, he is told that he would find a deep black tarn; and higher up, another. But to climb the mountain is a day's work, with much doubt of success, (that is, of a clear summit,) and he must to-day be satisfied with what is below. Yewdale, with its grey rocks, cushioned with heather up to their surnmits, stretches away northwards from the head of the lake, into a gorge where the mountains overlap. One of the crags there is called Raven Crag: and it is said that a pair of ravens is living now, there or somewhere near. It is to be hoped that, now the eagles are gone, the last ravens will not be destroyed or scared away by the shot of the miners, or other rash sportsmen, who are too apt to bring down every bird they see. There are many picturesque dwellings in the area which is between the heights and the lake: but the best view of these is from the point to which the stranger will proceed, after his lunch or early dinner. He must order his car to meet him in an hour at the junction of the two lake roads, on the Hawkshead road; and then he must walk a mile to the Waterhead, and then on, round the head of the lake, in the direction 
of Tent Lodge, which is seen nestling in its garden at some elevation above the lake. The road passes the site of the former Waterhead inn, now a young plantation of Mr. Marshall's. Then, commanding the whole expanse of the lake, it begins to ascend, as it curves round to the east; and, at about a mile and threequarters from the new inn, there stands the house in which Elizabèth Smith lived and died; and, on the opposite side of the road, Tent Lodge, built on the spot where a tent was pitched, that she might draw her dying breath with greater ease, and enjoy, as long as possible, the incomparable landscape there stretched before her. The boat-house is at the bottom of the slope, down which she used to take her mother's guests; and she and her sister were so well practiced at the oar that they could show the beauties of the scene from any. point of the lake. The first station is, however, from a field, - the first beyond the new house on Coniston Bank. Some people think this the finest view in the whole district: and truly, the frequent visitor pronounces it incomparable, every time he comes; and the passing tourist feels that, once seen, it can never be forgotten. Nowhere else, perhaps, is the grouping of the mountain peaks, and the indication of their recesses so striking; and as to the foreground, with its glittering waterfall, its green undulations, its diversified woods, its bright dwellings, and its clear lake, - it conveys the strongest impression of joyful charm, - of fertility, prosperity and comfort, nestling in the bosom of the rarest beauty.

Retracing his steps for some way, and passing the 


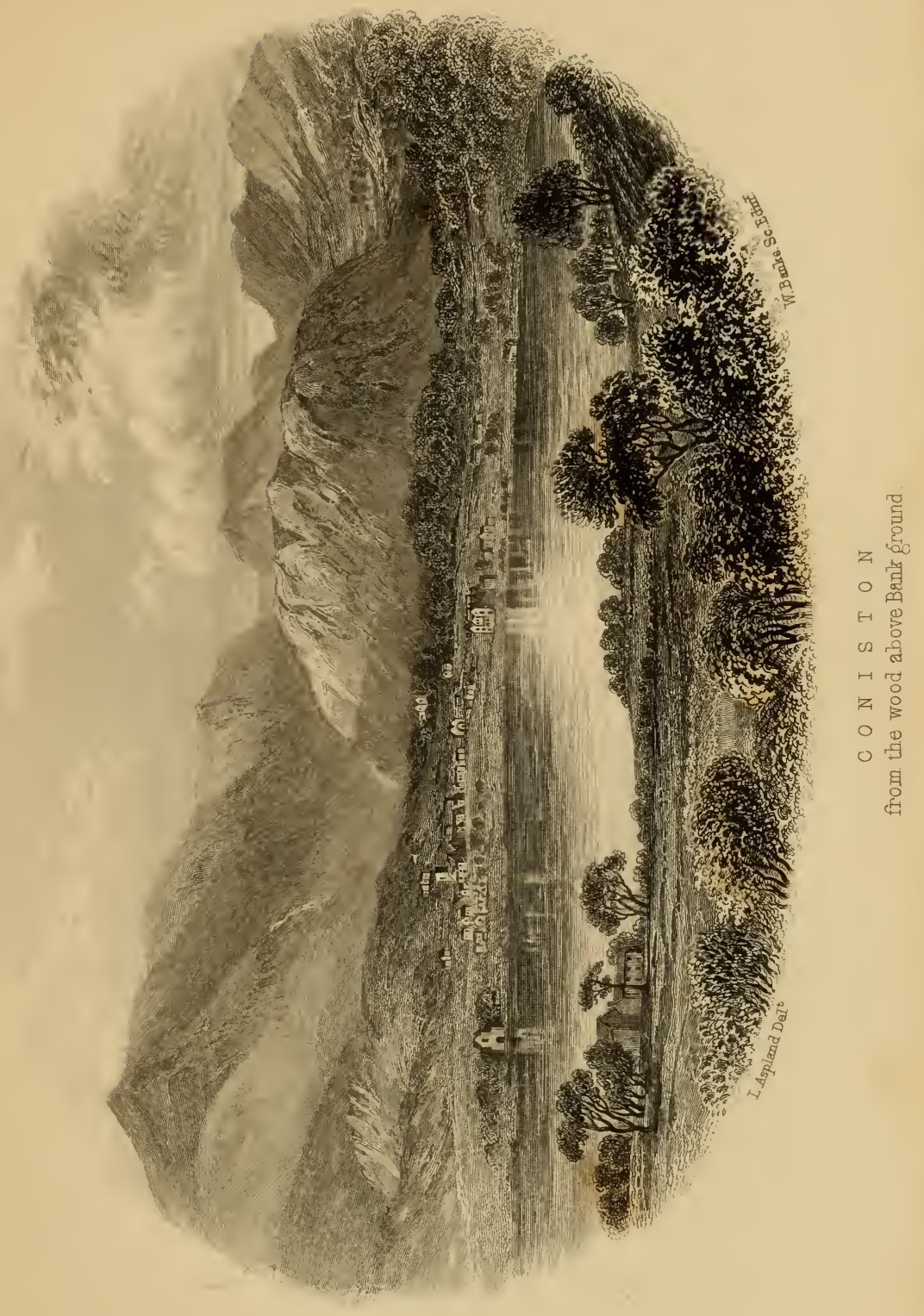



turn which would lead him down again to Tent Lodge, the stranger has rather a steep ascent before him, from point to point of which he finds, on looking behind him, new views of the lake appearing, while the magnitude of the old Man becomes more apparent as he recedes from it. By the roadpost, which indicates the two ways to the two sides of the lake, he finds his car; and then he proceeds through a wild country - moorland, sprinkled with grey rock, - in the direction of Hawkshead; which is three miles from Waterhead.

The parish church of Hawkshead is ancient; its appearance is venerable; and it stands, as a church should do, in full view of the country round, - of the valley in which Esthwaite Water lies. Elizabeth Smith lies buried there; and there is a tablet to her memory in the churchyard. At the ancient Grammar School of Hawkshead, Wordsworth and his brother were educated. Passing through the neat little town, the road turns to the left, to reach the northern end of Esthwaite Water, which is two miles long, and half a mile broad;-a quiet sheet of water, with two promontories stretching into it, which appear like islands, nearly dividing it into a chain of ponds. A round pond at the northern end of the lake, connected with it by a narrow creek, exhibits a strange phenœmenon. It has a floating island, - not like that of Derwentwater, which is a mass of mud and vegetable tangle, - but actually bearing trees : and this island is carried by strong winds from the one side to the other. The name of the pond is Priest's Pot: a fact which some explain by a tradition that a priest was drowned there; and others by a supposition of its 
holding about as much as a thirsty priest would like to drink, if the liquor were sufficiently good. Lakebank is a pretty place; and further on, Lakefield, (J. R. Ogden's, Esq.,) at Near Sawrey, commands perhaps the best view in the valley. Just beyond, the road turns to the left, through an undulating country of considerable beauty. We find a trace of the rebellion of 1745 in the name of a lane, called "Scotch Gate" (way.) It was here that the fearful Highlanders were looked for, on their march to Derby ; and here they might have had all their own way if they had come; for Sawrey had no idea of showing fight. All the inhabitonts, carrying all their valuables, hied away, and took refuge together in a solitary building which was called Cook's braw bog-house. And braw it must have been, to hold all the Sawreyans. The view of Windermere from the highest point is very fine. The road leads through Farther Sawrey to the Ferry House. If there is daylight left, (and there may be, as the Ferry is only seven miles from Coniston Waterhead) the traveller may as well go to the Station House, which he must have seen from the opposite side of the lake, peeping out of the ever-green woods. There he obtains fine views, up and down the lake, and may mark, on the way up, the largest laurels he has ever seen. His driver, or some resident, will probably take care that he does not stay till it is more than reasonably dusk. As reasons in plenty are always found for not marrying on a Friday, so it is said to be impossible, somehow or other, to get over to the Ferry Nab in the ferry-boat, except by daylight. And if you should 
arrive at the $\mathrm{Nab}$ too late, you may call all night for the boat, and it will not come. The traveller may judge for himself how much of the local tale may be true. He may probably have heard of the Crier of Claife, whose fame has spread far beyond the district: but if not, he should hear of the Crier now, while within sight of Ferry Nab. If he asks who or what the Crier was, - that is precisely what nobody can tell, though every body would be glad to know: but we know all how and about it, except just what it really was. It gave its name to the place now called the Crier of Claife, the old quarry in the wood, which no man will go near at midnight :-

It was about the time of the Reformation, one stormy night, when a party of travellers were making merry at the Ferry-house, - then a humble tavern, that a call for the boat was heard from the Nab. A quiet, sober boatman obeyed the call, though the night was wild and fearful. When he ought to be returning, the tavern guests stepped out upon the shore, to see whom he would bring. He returned alone, ghastly and dumb with horror. Next morning, he was in a high fever; and in a few days he died, without having been prevailed upon to say what he had seen at the Nab. For weeks after, there were shouts, yells, and howlings at the Nab, on every stormy night: and no boatman would attend to any call after dark. The Reformation had not penetrated the region; and the monk from Furness who dwelt on one of the islands of the lake, was applied to to exorcise the Nab. On Christmas day, he assembled all the inhabitants on Chapel Island, and 
performed in their presence services which should for ever confine the ghost to the quarry in the wood behind the Ferry, now called the Crier of Claife. Some say that the priest conducted the people to the quarry and laid the ghost, - then and there. - Laid though it be, nobody goes there at night. It is still told how the foxhounds in eager chase would come to a full stop at that place; and how, within the existing generation, a schoolmaster from Colthouse, who left home to pass the Crier, was never seen more. Whatever may be said about the repute of ghosts in our day, it is certain that this particular story is not dead.

Meantime, the heavy, roomy ferry-boat is ready : the horse is taken out of the car; and both are shipped. Two or three, or half-a-dozen people take advantage of the passage: the rowers, with their ponderous oars, are on the bench; and the great machine is presently afloat. The Ferry House looks more tempting than ever when seen from under its own sycamores, - jutting out as it does between quiet bays on either hand. The landing takes place on the opposite promontory: the horse is put to, and the traveller is presently at his inn. He is ready for his meal (be it tea or supper) of lake trout or char. The best char are in Coniston Water: but they are good every where; especially to hungry travellers, sitting at table within sight of the waters whence they have just been fished. The potted char of Coniston is sent, as every epicure knows, to all parts of the world where men know what is good. As for the trout, there can be none finer than that of Windermere. 


\section{SECOND TOUR.}

BY TROUTBECK TO KIRKSTONE PASS AND PATTERDALE, AND DESCENT UPON AJRLESIDE.

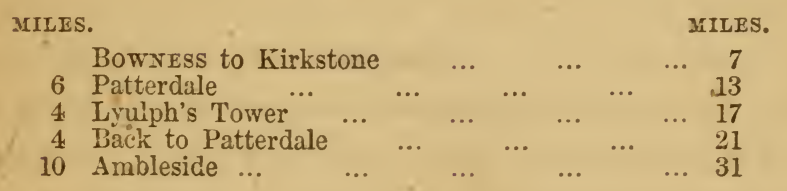

"As the traveller will have other opportunities of observing the six miles of mailroad between Bowness and Ambleside, he may as well go round, and see Ullswater, on the day of his removal. Sending his luggage on by the omnibus to one of the three chief Ambleside inns, he will take a car for the day, and go by Troutbeck to Patterdale.

The country people will tell him, as he turns up to Troutbeck at Cook's House, that he is going to see "the handsomest view in these parts, - especially at the back-end of the year." And wonderfully fine the views are, as the road ascends, commanding the entire lake, and the whole range of mountains from Coniston Old Man to Fairfield. The singular valley of Troutbeck was once a wooded basin, where the terrified Britons took refuge from the Romans, while the latter were making their great road from Kendal to Penrith. That road actually ran along the very ridge of the 
Troutbeck hills, as any one may see who will climb the mountain called, for this reason, High Street. What a sight it must have been - the pioneers felling the trees, and paving the way, and the soldiers following, with their armour and weapons gleaming in the sun, while the trembling natives cowered in the forest below, - listening now to the blows of the workmen, and now to the warlike music of the troops, marching up from Kendal! After Romans and Saxons were gone, the valley was a great park, and the inhabitants were virtually serfs, in danger of the gallows, (which had a hill to itself, named after it to this day) at the will and pleasure of the one great man. In course of time, - that is, a good many centuries ago, - the valley was disparked, and divided among the inhabitants, - only one very large estate being left, - the new park, containing 2,000 acres. This was the estate given by Charles I, to Huddlestone Phillipson, for his services in the civil wars. The valley now contains a string of hamlets, - Town End, Town Head, High Green, Crag, and High Fold; and its farmsteads and outbuildings show some of the most curious specimens of ancient edifices that are to be seen in the district. Josiah Brown, whom we mentioned in connexion with Orrest Head, found nearly his match in oddity in this vale. A "rum fellow" in Troutbeck had a prodigious bull; and so had Josiah : and what must they do but meet half-way, and have a bull-fight; the terms being that the winner should have the fallen animal. Josiah actually came riding his bull. The battle was tremendous; and the Troutbeck animal went down before Josiah's, and 
was given by him to the poor of Troutbeck. These anecdotes appear very strange to people who have lived in towns, or among the more level manners of the south: and this is why we relate them. They are among the euriosities of the district. Troutbeck is the most primitive of the frequented valleys of the district. To find any other so antique and characteristic, it is necessary to leave the high road, and explore the secluded dales of which the summer tourist sees and hears nothing. The dale looks from the uplands as if it had been scooped out between the ridges with a gigantic scoop. Its levels are parcelled out into small fields, of all manner of shapes; and the stream, - the beck abounding in trout,- -winds along the bottom, from the foot of High Street, to fall into the lake just by Calgarth.

The road now followed by the tourist descends into the vale sharply, by the abode of John Wilson, Esq., at The How, and crosses the bridge, in full view of the chapel, which was consecrated in 1562, and thoroughly repaired in 1828. It is one of the small churches that, with their square tower and bell, look and sound so well in the dales. This one seats 160 worshipers. Immediately beyond the bridge, the road mounts again very steeply, till it joins that which runs along the hill sides, on the western side of the valley. This road is to be followed up the valley; and the tourist must lose none of its beauties. Behind him, there are views of the receding lake, now diminished to the likeness of a cabinet picture :- below, is the deep vale with its green levels : opposite, the grassy slopes ascend to the ridges of High Street and Hill Bell; and before him, Troutbeck Tongue 
protrudes, splitting the valley into two, and being itself most lovely with its farmstead, and dropped thorns, and coppice and grey rocks : while, behind and above it, the vale head rises into grandeur, with its torrents leaping down, and its pathway winding up, indicating the pass into Mardale. The stranger is not going that way, however. He turns over a gentler pass to the left, which leads him, on the slope of Wansfell, away from Troutbeck. As he bids farewell to the Tongue, he sees the summit of Kirkstone before him. He is passing over the somewhat boggy upland where the Stock takes its rise, to flow down to and through Ambleside, after having taken the leap called Stockghyll Force. The tourist may see that in the evening, if there is time :he is going the other way now.

His road meets the one from Ambleside at a small public-house, which the Ordnance Surveyors have declared the highest inhabited house in England: and thus it is labelled by a board over the porch. In clear weather, the sea is seen hence, and the thread of smoke from its steamers. The head of Windermere lies like a pond below: the little Bielham tarn, near Wray Castle, glitters behind; and range beyond range of hills recedes to the horizon. Near at hand, all is very wild. The Ambleside road winds up steeply between grey rocks and moorland pasture, and dashing streams; and the Kirkstone mountain has probably mists driving about its head. There is something wilder to come, however, - the noted Kirkstone Pass, - the great pass of the district. The descent begins about a quarter of a mile beyond the house. Down 
plunges the road, with rock and torrent on either hand, and the bold sweeps of Coldfield and Scandale Screes shutting in the pass; and the little lake of Brothers' Water lying below, afar off among the green levels; and, closing in the whole in front, the mass of Place Fell, - the other side of which goes sheer down into Ullswater. The stranger must not omit to observe near the head of the pass, the fallen rock, ridged like a roof, whose form (like that of a miniature church) has given its name to its precincts. All the way as he descends to Brothers' Water, the openings on the Scandale side (the left) charm his eye, - with their fissures, precipices, green slopes and levels, and knolls in the midst, crowned with firs. He passes through Hartsop, and then winds on, for three or four miles, among the rich levels of Patterdale, which is guarded by mountains jutting forwards, like promontories. The Patterdale Inn, kept by Mr. Gelderd, is another of the first-rate hotels of the district. The stranger, who must have left Windermere early in the morning, hastens to order a car or a boat, to take him to Growbarrow Park, and desires that dinner may await him in about three hours' time.

If the weather is calm and fine, he has a boat, to which he must walk across the meadows. As soon as he is afloat, the beauties of Ullswater open upon him, - the great Place Fell occupying the whole space to the right; and Stybarrow Crag, precipitous and wooded, shoots up on the left-hand bank. The road winds below it, under trees, passing good houses, and the paths to Helvellyn, and to the lead works, and to 
Glencoin, - all recesses full of beauty. Tales are told of artists who, turning into Glencoin, to find materials for a sketch, have not come out again for three months, finding themselves overwhelmed with tempting subjects for the pencil. The singularly primitive character of the popular mind in those secluded corners is almost as great an incitement to study as the variety and richness of the foregrounds and the colouring.

Uliswater has two bends, and is shaped like a relaxed Z. At the first bend, the boat draws to shore, below Lyulph's Tower, an ivy-covered little castle, built for a shooting-box by the late Duke of Norfolk ; but it stands on the site of a real old tower, named, it is said, after the Ulf, or L'Ulf, the first Baron of Greystoke, who gave its name to the lake. Some, however, insist that the real name is Wolf's Tower. The park which surrounds it, and stretches down to the lake, is studded with ancient trees; and the sides of its watercourses, and the depths of its ravines, are luxuriantly wooded. Vast hills, with climbing tracks, rise behind, on which the herds of deer are occasionally seen, like brown shadows from the clouds. They are safe there from being startled (as they are in the glades of the park) by strangers who come to find out Ara Force by following the sound of the fall. Our tourist must take a guide to this waterfall from the tower.

He will be led over the open grass to the ravine, and then along its wooded sides on a pathway above the brawling stream, till he comes to a bridge, which will bring him in full view of the fall. As he sits in the cool damp nook at the bottom of the chasm, where the 


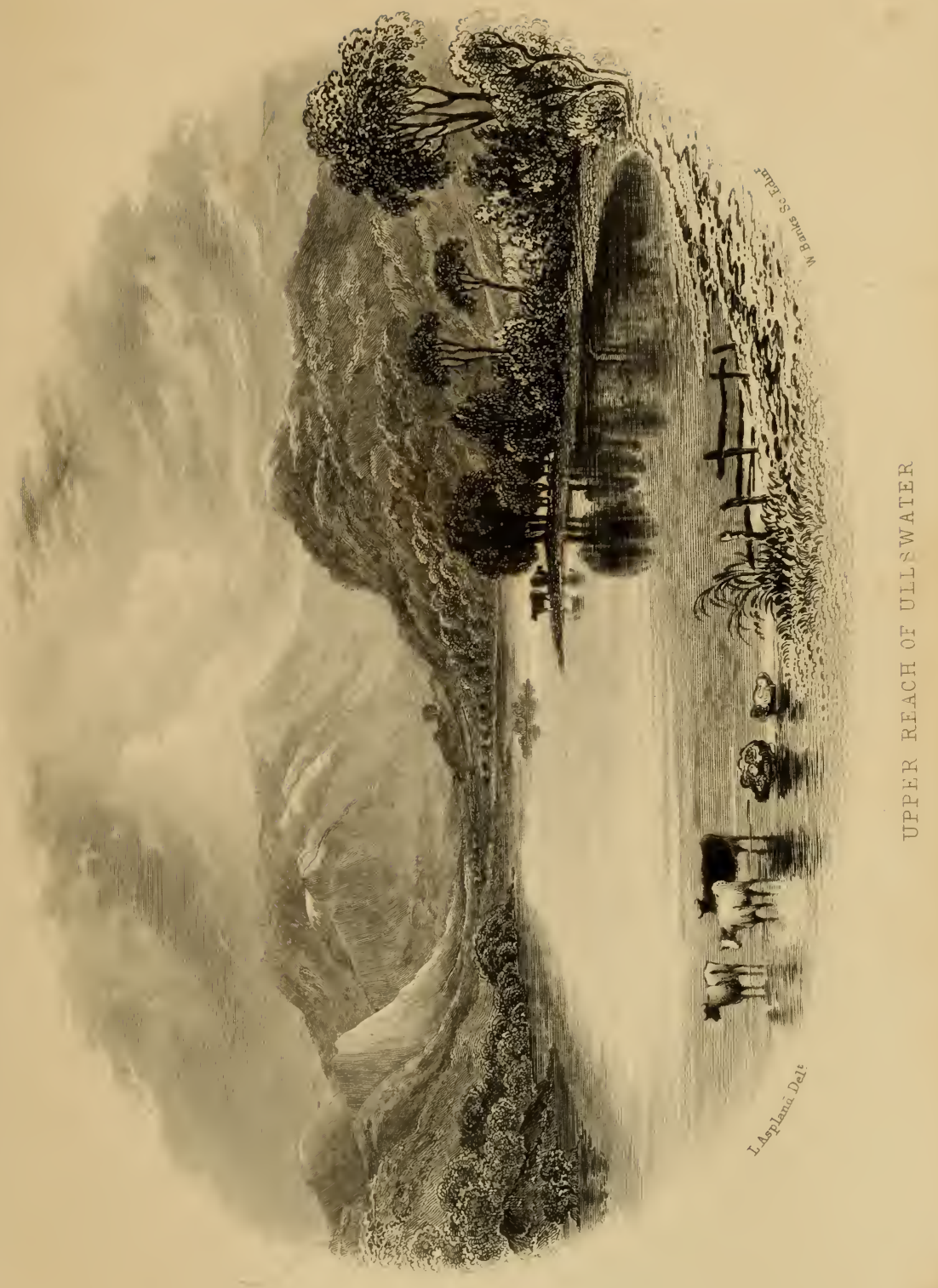



echo of dashing and gurgling water never dies, and the ferns, long grasses and ash sprays wave and quiver everlastingly in the pulsing air ; and as, looking up, he sees the slender line of bridge spanning the upper fall, he ought to know of the mournful legend which belongs to this place, and which Wordsworth has preserved:In the olden times, a knight who loved a lady, and courted her in her father's tower here, at Greystoke, went forth to win glory. He won great glory : and at first his lady rejoiced fully in it: but he was so long in returning, and she heard so much of his deeds in behalf of distressed ladies, that doubts at length stole upon her heart as to whether he still loved her. These doubts disturbed her mind in sleep : and she began to walk in her dreams, directing her steps towards the waterfall where she and her lover used to meet. Under a holly tree beside the fall they had plighted their vows, and this was the limit of her dreaming walks. The knight at length returned to claim her. Arriving in the night, he went to the ravine to rest under the holly until the morning should permit him to knock at the gate of the tower: but he saw a gliding white figure among the trees: and this figure reached the holly before him, and plucked twigs from the tree, and threw them into the stream. Was it the ghost of his lady love? or was it herself? She stood in a dangerous place: he put out his hand to uphold her: the touch awakened her. In her terror and confusion she fell from his grasp into the torrent, and was carried down the ravine. He followed and rescued her; but she died upon the bank; not, however, without having fully c 3 . 
understood that her lover was true, and had come to claim her. The knight devoted the rest of his days to mourn her: he built himself a cell upon the spot, and became a hermit for her sake.

The visitor should ascend the steps and pathway from the bottom of the fall, and stand on the bridge that spans the leap. It is a grand thing to look down.

He returns the way he came, by boat, to the inn, and, after dinner up Kirkstone Pass. He will hear and see enough to make him wish to come again, and stay awhile on Ullswater. He would like to walk along Place Fell, above the margin of the lake, where no carriage road is or can be made; and, once there, he would certainly climb the mountain. He would like to enter the bridle road, from the foot of the lake, which leads to Grisedale tarn, and comes out above Grasmere. $\mathrm{He}$ would like to visit Angle Tarn, on the southern end of Place Fell ; and, yet more, Hays Water, the large lonely tarn above Hartsop; where the angler delights to seclude himself, because the trout delights in it too. It is a high treat to follow up the beck from the road, winding among the farms, and then entering the solitude of the pass, till the source of the stream is found in this tarn, a mile and a-half from the main road. The little lake is overhung by High Street, so that the Roman eagles, as well as the native birds of the rocks, may have cast their shadows upon its surface. Its rushy and rocky margin is as wild a place as the most adventurous angler can ever have found himself in. Our traveller must, however, come again to see it; for there is no time to diverge to it to-day. 
At the house, at the top of the pass, (which he has walked up, in mercy to his horses) he leaves the Troutbeck road to the left, and descends rapidly upon Ambleside, which is between three and four miles from the house. On the left, is the valley or ravine of the Stock, whose waters are concealed by wood. The road runs along the slopes of the Scandale Fells. Below, Windermere opens more and more; and at length, the pretty little town of Ambleside appears, nestling at the foot of Wansfell, and the valley of the Rothay opens at the gazer's feet. On the opposite margin of this green recess, and on the skirts of Loughrigg, he sees Fox How, the residence and favourite retirement of the late Dr. Arnold, and now inhabited by his family. Near the pass which opens between Loughrigg and Fairfield, he is told that the residence of Wordsworth may be seen from below. Just under him to the left is the old church; and near the centre of the valley is the new church, - more of a blemish than an adornment, unhappily, from its size and clumsiness, and the bad taste of its architecture. Though placed in a valley, it has a spire, - the appropriate form of churches in a level country; and the spire is of a different color from the rest of the building; and the east window is remarkably ugly. There have been various reductions of the beauty of the valley within twenty years or so; and this latest is the worst, because the most conspicuous. The old church, though not beautiful, is suitable to the position, and venerable by its ancient aspect. It is abundantly large enough for the place, except for a few weeks in summer : but its burial ground, inclosed by 
roads on three sides, has for many years been overcrowded. Ten years ago, the state of the churchyard, and the health of the people who lived near it, was such as to make the opening of a new burial-ground a pressing matter; and hence, no doubt, arose the new church, though a larger and more beautiful cemetery might easily have been formed in the neighbourhood.

The descent to all the Ambleside inns is steep, past the old church, and through a narrow street, and into the space dignified with the name of the marketplace, and actually exhibiting an ancient market-cross. Half-a-dozen of the few shops of the town are in or about the market-place, and the Salutation and Commercial Inns and the White Lion, - the three principal inns, are all conspicuous in it. If his time in Ambleside is precious, the stranger may use the sunset or twilight hour for seeing Stockghyll Force, while his supper is preparing. He is directed or guided through the stable-yard of the Salutation Inn, when he passes under a tall grove of old trees on the right hand, the stream being on the left. On the opposite bank is the bobbin-mill, the one industrial establishment of Ambleside, placed there on account of the abundant supply of coppice wood obtainable in the neighbourhood. The stacks of wood are seen, high up on the bank; and the ivy-clad dwelling of the proprietor; and then the great water-wheel, with its attendant spouts and weir, and sound of gushing and falling waters. Where the path forks towards and away from the stream, the visitor must take the left-hand one. The other is the way up Wansfell. His path leads him under trees, and up and 
through a charming wood, with the water dashing and brawling further and further below, till his ear catches the sound of the fall: and presently after, the track turns to the left, and brings him to a rocky station whence he has a full view of the force. It is the fashion to speak lightly of this waterfall, - it being within half-a-mile of the inn, and so easily reached; but it is, in our opinion, a very remarkable fall, (from the symmetry of its parts,) and one of the most graceful that can be seen. Its leap, of about seventy feet, is split by a rocky protrusion, and intercepted by a ledge running across; so that there are four falls, - two smaller ones above, answering precisely to each other, and two larger leaps below, no less exactly resembling. The rock which parts them is feathered with foliage; and so are the sides of the ravine. Below, the waters unite in a rocky basin, whence they flow down to the mill, and on in a most picturesque torrent, through a part of Ambleside, and into the meadows, where they make their last spring down a rock near Millar Bridge, and join the Rothay about a mile from the lake.

Supposing the excursion to Patterdale to be left for another day, the stranger will see, after turning into the . Ambleside road from Bowness, first, Ibbotsholme, on the right, the residence of Samuel Taylor, Esq., just beyond Troutbeck Bridge. Presently, he will pass on the left hand, the gate of Calgarth, Bishop Watson's house, now inhabited by Edward Swinburne, Esq. Ecclerigg, the residence of Rd. Luther Watson, Esq., comes next : and then Lowwood Inn, Dove's Nest, and Wansfell Holme, and, on the opposite shore, Wray 
Castle, all of which have been mentioned as seen from the lake. Clappersgate, with its white houses, nestles under Loughrigg, at the head of the lake; and the Brathay valley, with its pretty little church on its knoll, opens beautifully as seen from the toll-bar. From Water-head to Ambleside, there are residences, humble or handsome, on either hand. The traveller can hardly be wrong in his choice of an inn, as all three are comfortable and well served. At present there are no baths in the place; - a singular deficiency where there is so much of company on the one hand and of water on the other. The inconvenience is, however, in the way of being remedied; and it is to be hoped that another season will not arrive without a provision of this needful refreshment for the dusty and tired traveller, - to say nothing of the residents, who must desire it for purposes of health as well as enjoyment. 


\section{THIRD TOUR.}

BY THE VALLEY OF THE BRATHAY, TO HIGH CLOSE, AND DOWN RED BANK TO GRASMERE AND EASTHWAITE, AND THENCE BY RIDAL TO AMBLESIDE.

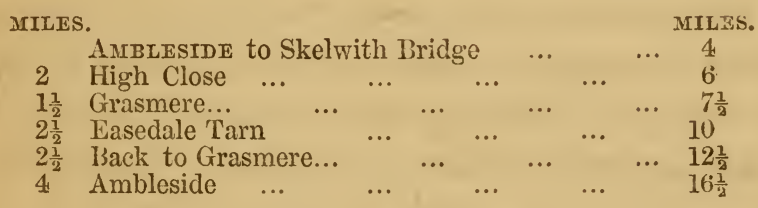

The stranger had better take an entire day for this tour also, if he can spare the time, and means to see Easedale at his ease. The distance in miles is not a day's journey; but there are things to see which deserve a pause.

The road to the right, after leaving the little market place, is the one to be taken. Between Rothay Cottage and Rothay Bank, the residence of John Crosfield, Esq., the road turns upon Rothay Bridge, whence there is a fine view of the valley, with the cul-de-sac of Fairfield closing it in to the north. Whether the vapours are gathering and tumbling in that basin, - the recess of Fairfield, - or whether every projection, streak, slide, and mossy tract is clearly visible, that northern barrier is very imposing; and perhaps most so to those who are most familiar with it, and can read its manifold weather signs and tokens. Between Rothay Bridge and Clap- 
persgate is Croft Lodge, the residence of James Holme, Esq.; - the mansion and its woods being on the right of the road, and the gardens stretching down to the river on the left. Then comes the pretty hamlet of Clappersgate, so conspicuous from the lake; and two roads branch off, leading along each bank of the river Brathay, and meeting at Skelwith Bridge at the other end of the valley. If the stranger has any thought of ascending Loughrigg, some other day, he may now see, above Clappersgate, the path by which he may ascend or descend; a zig-zag path up the hill side, leading to the two peaks, crowning the south end of Loughrigg, from between which the most perfect possible view of Windermere is obtained. That cannot, however, be done to-day. The left-hand road should now be taken, crossing Brathay Bridge, and passing the parsonage. When the stranger sees the churchyard gate, he must alight, and walk up to the church. From the rock there he commands the mountain range from Coniston Old Man to the Langdale Pikes: the Brathay flows beneath, through its quiet meadows; and its dashing among the rocks, just under his feet, catches his ear;-Loughrigg, with its copses and crags and purple heather, rises immediately before him: and to the right he sees a part of Ambleside nestling between the hills, and a stretch of the lake. This churchyard has the first daffodils and snowdrops on the southern. side of its rock; and, in its copse, the earliest wood anemones. Throughout the valley, spring flowers, and the yellow and white broom abound.

The road ascends and descends abruptly, and winds 
towards, and away from, the right bank of the Brathay, till it reaches Skelwith Fold. There the stranger must alight again, and go through a field gate to the right, to a rocky point, where he commands the finest view of the valley and its environs. And again, just before he comes to Skelwith Bridge, he must go through the gap in the wall to the left, and follow the field-track until he comes in sight of Skelwith Force. He will hardly aver that he ever saw a more perfect picture than this, - with the fall in the centre, closed in by rock and wood on eithẻr hand, and by the Langdale Pikes behind. Returning to his car, he will next pass over the bridge, and the roaring torrent beneath, and by stacks of wood, - (more coppice wood for another bobbin-mill,) and, turning to the right, will find that he has headed the valley. As he is not going home, however, but to Grasmere, he turns out of the Brathay valley by a steep road on the left, which ascends again and again, leading by farmsteads almost as primitive as those of Troutbeck, and evidently mounting the spurs of Loughrigg, - which he is travelling round to-day, and which must therefore be always on his right hand. After a while, he comes to a sheet of water, so still, if the day be calm, that he might possibly miss it, unless the precision of the reflections should strike his eye. It is more likely, however, to be rippled by some breeze, and to show how deeply blue, or darkly grey, these mountain tarns may be. This is Loughrigg tarn, well known to all readers of Wordsworth. At some little distance beyond it, the stranger must diverge from his road to visit High Close, and see the view which is re- 
puted the finest in Westmorland. He may leave his car where the road to High Close ascends to the left, and walk to the farm-house at the top. As there are probably lodgers, he had better not present himself at the garden door, but go on to the farmyard gate, pass through the yard to the field, and walk along the brow till he reaches the grey stone bench. There he is! overlooking "the finest view in Westmorland." To the extreme right, Bowfell closes in the Langdale valley, the head of which is ennobled by the swelling masses of the Pikes. A dark cleft in the nearer one is the place where the celebrated Dungeon Ghyll Force is plunging and foaming, beyond the reach of eye and ear. He can gather from this station, something of the character of Langdale. It has levels, here expanding, there contracting; and the stream winds among them from end to end. There is no lake: and the mountains send out spurs, alternating or meeting, so as to make the levels sometimes circular and sometimes winding. The dwellings are on the rising grounds which skirt the levels; and this, together with the paving of the road below, shows that the valley is subject to floods. The houses, of grey-stone, each on its knoll, with a canopy of firs and sycamores above it, and ferns scattered all around, and ewes and lambs nestling near it, -- these primitive farms are cheerful and pleasant objects to look upon, whether from above or passing among them. Nearer at hand are some vast quarries of blue slate. Below, among plantations, are seen the roofs of the Elterwater Powder Mills; whence the road winds through the village of Langdale Chapel, to the margin 
a

a 


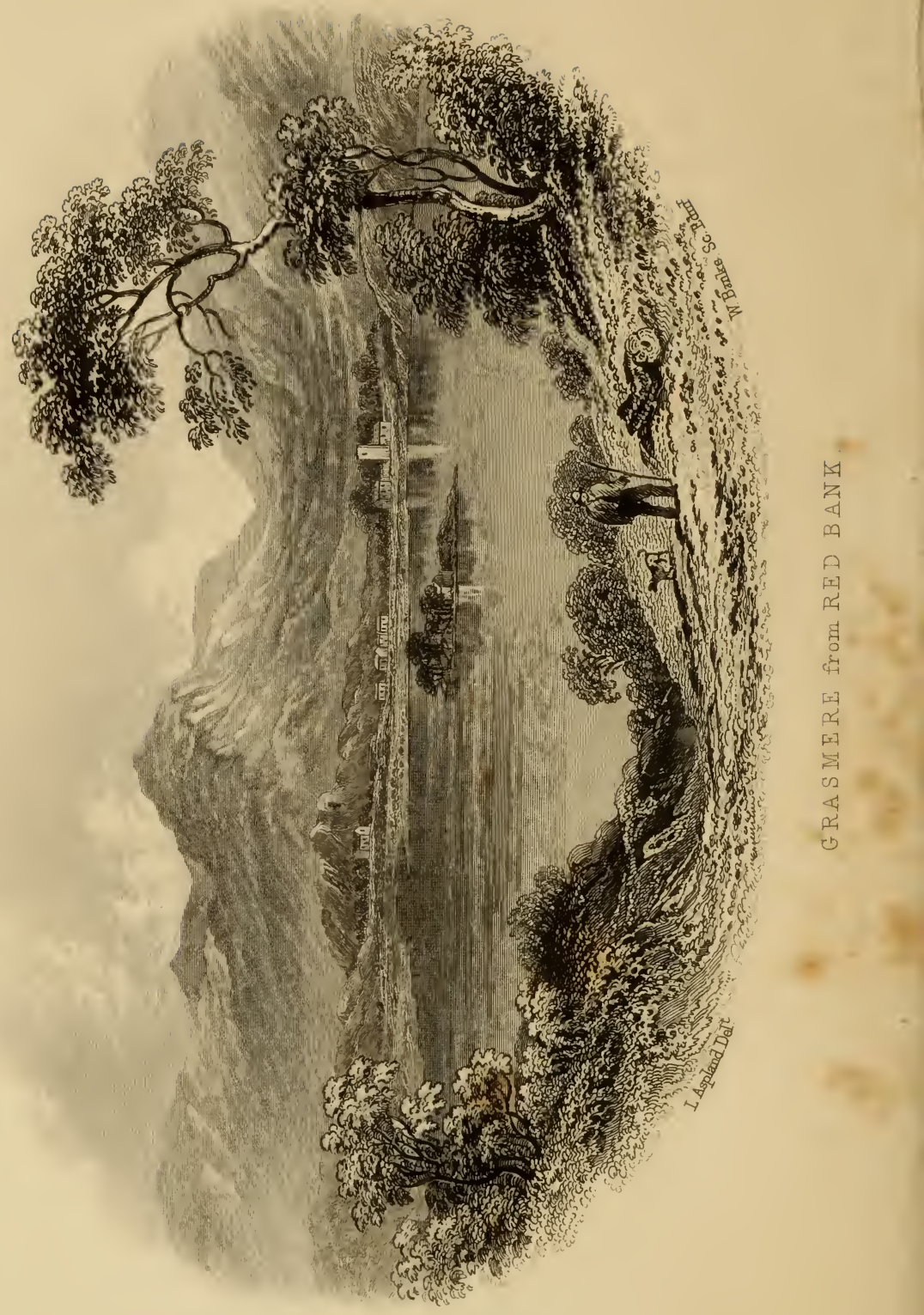


of the pools which make up the lake. From their opposite shore rise the hills, height above height, range beyond range. To the left lies Loughrigg Tarn, and, in the distance, Windermere, with Wray Castle prominent on its height, and the Lancashire hills closing in the view. It is a singular prospect, at once noble and lovely; and the comfortable lodgings at High Close farm are in request accordingly.

The car is waiting where the traveller left it; but he had better walk for half-a-mile or so, - the descent of Red Bank being very steep. The great mountain that swells so grandly above the rest before him is Helvellyn. The lake that opens below is Grasmere, with its one island, made up of green slope, black fir clump, and grey barn. At the further end lies the village, with its old square church tower, beneath whose shadow Wordsworth is buried. The white road that winds like a ribbon up and up the gap between Helvellyn and the opposite fells is the mail road to Keswick, and the gap is Dunmail Raise. The remarkable and beautiful hill behind the village is Helm Crag; and its rocky crest forms the group called the Lion and the Lamb. The long white house, near the foot of Helvellyn, is the Swan Inn, whence Scott, Southey, and Wordsworth, set forth on ponies for the ascent of the mountain : and behind it rises the path by which pedestrians come from Grasmere to Patterdale, by the margin of Grisedale tarn, - the mountain tarn of the wild boar, as the words properly signify. To the left of Helm Crag, a deep valley evidently opens. That is Easedale; and there our tourist is to go to-day. Meantime, let him 
linger awhile, that he may learn by heart every feature of this gay and lovely scene. The lane he has just passed to the right leads him to the grassy bridle-road called Loughrigg Terrace, whence the best views are obtained of both Grasmere and Rydal lakes, and which leads along the uplands and then by Rydal Lake back to the valley of the Rothay. We must leave it now, and plunge down Red Bank, which has the characteristics of a Norwegian road. At the cistern at-the bottom, the stranger enters his car, and passes farm houses between him and the lake, and villas on the rocky and wooded bank on the left; and, at the corner, where the road turns to the village, the cluster of lodging-houses, called St. Oswald's, where the Hydropathic Establishment struggled on for a time, but found the Westmorland winters too long for invalids.

The driver must stop at the Red Lion, to order dinner. It is an old-fashioned little place, where the traveller's choice is usually between ham and eggs and eggs and ham; with the addition, however, of cheese and oat cake. He goes to the Red Lion now merely because it is on the way to his destination. If he were going to stay at Grasmere, he would take up his abode at the Hotel kept by Mr. Brown. The beauty of the view from that house is evident at a glance; and good accommodations will be found within, with ample means of conveyance of all kinds. Whatever the dinner at the Red Lion is to be, it must not be ready under two or three hours; - rather three than two. He proceeds for a mile between fences before he reaches the opening of Easedale. The gate 
and shrubbery to the right are the entrance to Lady Richardson's cottage; and there the regular road ends. The car can go about a mile further along the farm tracks in the valley, through the meadows which yield a coarse hay, and near the stream which is tufted with alders. At the farm house where the car stops, the people will shew the stranger the way he must go, past the plantation, and up the hill side, where he will find the track that will guide him up to the waterfall, - the foaming cataract which is seen all over the valley, and is called Sour Milk Ghyll Force. The water and the track together will shew him the way to the tarn, which is the source of the stream. Up and on he goes, over rock and through wet moss, with long stretches of dry turf and purple heather; and at last, when he is heated and breathless, the dark cool recess opens in which lies Easedale Tarn. Perhaps there is an angler standing besides the great boulder on the brink. Perhaps there is a shepherd lying among the ferns. But more probably the stranger finds himself perfectly alone. There is perhaps nothing in natural scenery which conveys such an impression of stillness as tarns which lie under precipices : and here the rocks sweep down to the brin's almost round the entire margin. For hours together the deep shadows move only like the gnomon of the sundial; and, when movement occurs, it is not such as disturbs the sense of repose; - the dimple made by a restless fish or fly, or the gentle flow of water in or out; or the wild drake and his brood, paddling so quietly as not to break up the mirror, or the reflection of some touch of sunlight, or passing shadow. 
If there is commotion from gusts or eddies of wind, the effect is even more remarkable. Little white clouds are driven against the rocks, - the spray is spilled in unexpected places; now the precipices are wholly veiled, and there is nothing but the ruffled water to be seen : and again, in an instant, the rocks are disclosed so fearfully that they seem to be crowding together to crush the intruder. If this seems to the inexperienced like extravagance, let him go alone to Easedale 'Tarn, or to Angle Tarn on Bowfell, on a gusty day, and see what he will find.

After his return to the Red Lion, and his dinner, the stranger will go to the churchyard. In the church is a medallion portrait of Wordsworth, accompanied by an inscription adapted from a dedication of Mr. Keble's. The simple and modest tombstone in the churchyard will please him better. At present it bears only the name of the poet, - in his case, an all-sufficient memorial: but it is understood that some dates and other particulars will be filled in hereafter. Beside him lies his only daughter, and next to her, her husband, whose first wife is next him on the other side. Some other children of Wordsworth, who died young, are buried near; and one grandchild. Close behind the family group lies Hartley Coleridge, at whose funeral the white-haired Wordsworth attended, not very long: before his own death. This spot, under the yews, besides the gushing Rothay and encircled by green mountains, is a fitting resting-place for the poet of the region. He chose it himself; and every one rejoices that he did. 


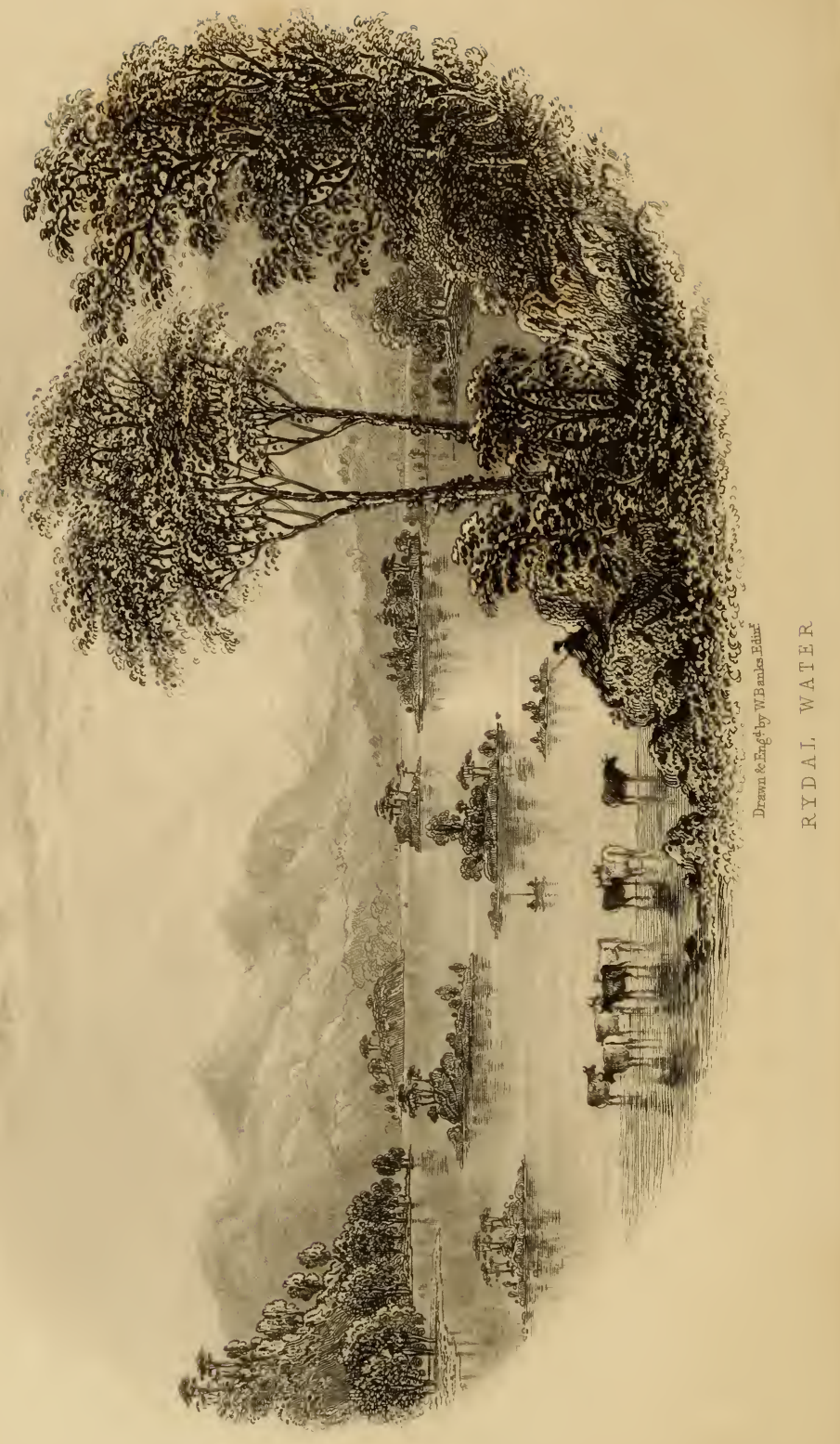


Just after entering the mail road, the driver will point out the cottage in which the poet and his sister lived, many long years ago, when Scott was their guest. Several good houses have sprung up near it, within a few years. The promontory which here causes the lake to contract to the little river (which is called the Rothay in all the intervals of the chain of lakes,) may be passed in three ways. The mail road runs round its point, and therefore keeps beside the water; - the Roman road, where the Wishing Gate used to be, crosses it by a rather steep ascent and descent; - and a shorter road still, steeper and boggy, cuts across its narrowest part, and comes out at the Rydal Quarries. Our traveller will take the mail road, probably. It will soon bring him to Rydal Lake; and he cannot but think the valley very lovely in the summer afternoon. On the opposite side of the lake is Loughrigg, with its terrace-walk distinctly visible half-way up. The islands are wooded; and on one of them is a heronry; and the grey bird, with its long flapping wings, is most likely visible, either in flight, or perched on a tree near its nest, or fishing in the shallows. Nab Scar, the blunt end of Fairfield, which overlooks the road and the lake, is very fine with its water-worn channels, its wood, and grey rocks. Nab Cottage, the humble white house by the road side, and on the margin of the lake, is the place where Hartley Coleridge lived and died. In the distance, Ivy Cottage peeps out of the green; and further on, Rydal Chapel rises out of the foliage on the verge of the park.

When the turn to the left, which leads up to that 
chapel, is reached, the stranger must alight, and ascend it. He is ascending Rydal Mount: and Wordsworth's house is at the top of the hill, - within the modest gate on the left. If the family should be absent, the traveller may possibly obtain entrance, and stand on the mossgrown eminence, (like a little Roman camp,) in front of the house, whence he may view the whole valley of the Rothay to the utmost advantage. Windermere in the distance is, as Wordsworth used to say, a light thrown into the picture, in the winter season, and, in summer, a beautiful feature, changing with every hue of the sky. The whole garden is a true poet's garden; its green hollows, its straight terraces, bordered with beds of periwinkle, and tall foxgloves, purple and white, - (the white being the poet's favourite); and then the summer house, - (now, however, damp and dreary, with the fircones that line it dropping out of their places) ; and then the opening of the door, which discloses the other angle of the prospect, - Rydal Pass, with the lake lying below. Every resident in the neighbourhood thinks the situation of his own house the best: but most agree that Wordsworth's comes next. We should say that Wordsworth's came next to Mr. Sheldon's at Miller Brow, but for the great disadvantage of the long and steep ascent to it. That ascent is a serious last stage of a walk on a hot summer day; but the privileges of the spot, when once reached, are almost incomparable.

The guide to the Rydal Falls will by this time have presented herself, and the tourist must visit them. They are within the park, and cannot be seen without 
a guide : but some one is always to be found at one of the two guides' cottages on the ascent of the hill. The upper fall is the finest, in the eyes of those who prefer the most natural accessaries of a cascade: but the lower is the one generally represented by artists, the summer-house from which it is viewed affording an admirable picture-frame, and the basin of rock, and the bridge above, constituting, in truth, a very perfect picture. When there is a dash of sunshine on the verdure, behind and under the bridge, to contrast with the shadowy basin and pool of the fall, the subject is tempting enough to the artist.

These falls seen, the tourist need alight from his car no more, for he is only a mile and a-half from Ambleside. He presently passes Pelter Bridge, which spans the Rothay on the right. That is the way to Fox How: and he presently sees Fox How, - the grey house embosomed in trees, - at the foot of Loughrigg. He must not mistake for it the gem of a house that he sees, - the cream-coloured one, veiled in roses, with the conservatories beside it, just under the wooded precipice:- that is Foxghyll, the residence of Hornby Roughsedge, Esq. To the left, there are good views of Rydal Park. Approaching Ambleside, the first house to the left is Lesketh How, the residence of Dr. Davy: the white house to the right is Tranby Lodge, the abode of Alfred Barkworth, Esq. : and the house on the rising ground behind the chapel is the Knoll, the residence of Miss. H. Martineau. The gates on the left are those of Green Bank, the estate of Benson Harrison, Esq. : and the pretty cottage next reached on the same

D 3 
side is that of James C. Wilson, Esq., called Low Nook. The stream to the right is the Stock, making its way to the river: and the odd little grey dwelling built above it is the ancient house which is considered the most curious relic in Ambleside of the olden time. The view of the mill and the rocky channel of the Stock on the left of the bridge is the one which every artist sketches as he passes by ; and if there is in the Exhibition in London, in any year, a view at Ambleside, it is probably this. The Kirkstone røad now joins the mail road, and the tourist finds himself on old ground, - in Ambleside market-place. 


\section{A DAY ON THE IIOUNTAINS.}

The stranger has now made his three tours. There is one thing more that he must do before he goes on into Cumberland. He must spend a day on the Mountains: and if alone, so much the better. If he knows what it is to spend a day so far above the every-day world, he is aware that it is good to be alone, (unless there is danger in the case) ; and, if he is a novice, let him try whether it be not so. Let him go forth early, with a stout stick in his hand, provision for the day in his knapsack or his pocket; and, if he chooses, a book: but we do not think he will read to-day. A map is essential, to explain to him what he sees : and it is very well to have a pocket compass, in case of sudden fog, or any awkward doubt about the way. In case of an ascent of a formidable mountain, like Scawfell or Helvellyn, it is rash to go without a guide: but our tourist shall undertake something more moderate, and reasonably safe, for a beginning.

What mountain shall it be? He might go up Blackcombe, on his way to or from Furness : and from thence he might see, in fair weather, as Wordsworth tells us, "a more extensive view than from any other point in Britain," - seven English counties, and seven 
Scotch, a good deal of Wales, the Isle of Man, and in some lucky moment, just before sunrise (as the Ordnance surveyors say) the coast of Ireland. This is very fine; but it is hardly what is looked for in the lake district, - the sea being the main feature. He might go up the Old Man from Coniston; but there are the copper works, and there is the necessity of a guide: and it is a long way to go for the day's treat. If he ascends the Langdale Pikes, it had better be from some interior station; and the rest of the great peaks will be best commanded from Keswick. Of those within reach of Ambleside, which shall it be? Loughrigg is very easy and very charming; but it is not commanding enough. From the surrounding heights it looks like a mere rambling hill. Wansfell is nearest, and also easy and safe. It may be reached by a charming walk from Low Wood Inn, and descended by the Stockghyll lane, above Ambleside. The immediate neighbourhood is mapped out below; and there is a long and wide opening to the south: but to the north-east, and everywhere round the head of the lake, the view is stopped, first by Nab Scar, and then by other heights. Why should it not be Nab Scar itself? or, the whole of Fairfield? That excursion is safe, not over fatiguing, practicable for a summer day, and presenting scenery as characteristic as can be found. Let it be Fairfield.

The stranger should ascend to the ridge, either through Rydal forest, (for which leave is requisite, and not always easily obtained,) or by the road to the Nook which anybody will shew him. The Nook is a farmhouse in a glorious situation as he will 
see when he gets there and steps into the field on the left, to look abroad from the brow. He then passes under its old trees to where the voice of falling waters calls him onward. Scandale Beck comes tumbling down its rocky channel, close at hand. He must cross the bridge, and follow the cart-road, which brings him out at once upon the fells. What he has to aim at is the ridge above Rydal forest or park, from whence his way is plain, - round the whole cul-de-sac of Fairfield, to Nab Scar. He sees it all; and the only thing is to do it: and we know of no obstacle to his doing it, unless it be the stone wall which divides the Scandale from the Rydal side of the ridge. These stone walls are an inconvenience to pedestrians, and a great blemish in the eyes of strangers. In the first place, however, it is to be said that an open way is almost invariably left, up every mountain, if the rover can but find it; and, in the next place, the ugliness of these climbing fences disappears marvellously when the stranger learns how they came there. - In the old times, when there were wolves, and when the abbots of the surrounding Norman monasteries encouraged their tenants to approach nearer and nearer to the Saxon fastnesses, the shepherds were allowed to inclose crofts about their hillside huts, for the sake of browsing their flocks on the sprouts of the ash and holly with which the hillsides were then wooded, and of protecting the sheep from the wolves which haunted the thickets. The inclosures certainly spread up the mountain sides, at this day, to a height where they would not be seen if ancient custom had not drawn the lines which are thus preserved; and it 
appears, from historical testimony, that these fences existed before the fertile valleys were portioned out among many holders. Higher and higher ran these stone inclosures, - threading the woods, and joining on upon the rocks. Now, the woods are for the most part gone; and the walls offend and perplex the stranger's eye and mind by their unsightliness and apparent uselessness; but it is a question whether, their origin once known, they would be willingly parted with, - reminding us as they do of the times when the tenants of the abbots or military nobles formed a link between the new race of inhabitants and the Saxon remnant of the old. One of these walls it is which runs along the ridge and bounds Rydal Park. There may be a gate in it; or one which enables the stranger to get round it. If not, he must get over it; and, if he does so, high enough up, it may save him another climb. The nearer the ridge, the fewer the remaining walls between him and liberty. Once in the forest, Christopher North's advice comes into his mind, - unspoiled by the fear, only too reasonable in the lower part of the park, - of being turned out of the paradise, very summarily. "The sylvan, or rather, the forest scenery of Rydal Park," says Professor Wilson, "was, in the memory of living man, magnificent; and it still contains a treasure of old trees. By all means wander away into these old woods, and lose yourself for an hour or two among the cooing of cushats and the shrill shriek of startled blackbirds, and the rustle of the harmless glow-worm among the last year's beech leaves. No very great harm should you even fall asleep under the shadow of 
an oak, whilst the magpie chatters at safe distance, and the more innocent squirrel peeps down upon you from a bough of the canopy, and then, hoisting his tail, glides into the obscurity of the loftiest umbrage." Ascending from these shades through a more straggling woodland, the stranger arrives at a clump on the ridge, - the last clump, and thenceforth feels himself wholly free. His foot is on the springy mountain moss; and many a cushion of heather tempts him to sit down and look abroad. There may still be a frightened cow or two, wheeling away, with tail aloft, as he comes onwards; and a few sheep are still crouching in the shadows of the rocks, or staring at him from the knolls. If he plays the child and bleats, he will soon see how many there are. It is one of the amusements of a good mimic in such places to bring about him all the animals there are, by imitating their cries. One may assemble a flock of sheep, and lead them far out of bounds in this way; and bewildered enough they look when the bleat ceases, and they are left to find their way back again. It is in such places as this that the truth of some of Wordsworth's touches may be recognised, which are most amusing to cockney readers. Perhaps no passage has been more ridiculed than that which tells of the "solemn bleat" of

"a lamb left somewhere to itself,

The plaintive spirit of the solitude."

The laughers are thinking of a cattle market, or a flock of sheep on a dusty road; and they know nothing of the effect of a single bleat of a stray lamb high up on the mountains. If they had ever felt the profound 
stillness of the higher fells, or heard it broken by the plaintive cry, repeated and not answered, they would be aware that there is a true solemnity in the sound.

Still further on, when the sheep are all left behind, he may see a hawk perched upon a great boulder. $\mathrm{He}$ will see it take flight when he comes near, and cleave the air below him, and hang above the woods, - to the infinite terror, as he knows, of many a small creature there, and then whirl away to some distant part of the park. Perhaps a heavy buzzard may rise, flapping, from its nest on the moor, or pounce from a crag in the direction of any water-birds that may be about the springs and pools in the hills. There is no other sound, unless it be the hum of the gnats in the hot sunshine. There is an aged man in the district, however, who hears more than this, and sees more than people below would, perhaps, imagine. An old shepherd has the charge of four rain guages which are set up on four ridges, - desolate, misty spots, sometimes below and often above the clouds. He visits each once a month, and notes down what these guages record; and when the tall old man, with his staff, passes out of sight into the cloud, or among the cresting rocks, it is a striking thought that science has set up a tabernacle in these wildernesses, and found a priest among the shepherds. That old man has seen and heard wonderful things :has trod upon rainbows, and been waited upon by a dim retinue of spectral mists. He has seen the hail and the lightnings go forth as from under his hand, and has stood in the sunshine, listening to the thunder growling, and the tempest bursting beneath his feet. 
He well knows the silence of the hills, and all the solemn ways in which that silence is broken. The stranger, however, coming hither on a calm summer day may well fancy that a silence like this can never be broken.

Looking abroad, what does he see? The first impression probably is of the billowy character of the mountain groups around and below him. This is perhaps the most striking feature of such a scene to a novice; and the next is the flitting character of the mists. One ghostly peak after another seems to rise out of its shroud; and then the shroud winds itself round another. Here the mist floats over a valley; there it reeks out of a chasm: here it rests upon a green slope; there it curls up a black precipice. The sunny vales below look like a paradise, with their bright meadows and waters and shadowy woods, and little knots of villages. To the south there is the glittering sea ; and the estuaries of the Leven and Duddon, with their stretches of yellow sands. To the east there is a sea of hill tops. On the north, Ullswater appears, grey and calm at the foot of black precipices; and nearer may be traced the whole pass from Patterdale, where Brothers' Water lies invisible from hence. The finest point of the whole excursion is about the middle of the cul-de-sac, where, on the northern sides, there are tremendous precipices, overlooking Deepdale, and other sweet recesses far below. Here, within hearing of the torrents which tumble from those precipices, the rover should rest. He will see nothing so fine as the contrast of this northern view with the long green slope on the other side, down to the source of Rydal 
Beck, and then down and down to Rydal Woods and Mount. He is now 2,950 feet above the sea level ; and he has surely earned his meal. If the wind troubles him, he can doubtless find a sheltered place under a rock. If he can sit on the bare ridge, he is the more fortunate.

The further he goes, the more amazed he is at the extent of the walk, which looked such a trifle from below. Waking out of a reverie, an hour after dinner, he sees that the sun is some way down the western sky. He hastens on, not heeding the boggy spaces, and springing along the pathless heather and moss, seeing more and more lakes and tarns every quarter of an hour. In the course of the day he sees ten. Windermere, and little Blelham Tarn beyond, he saw first. Ullswater was below him to the north when he dined; and, presently after, a tempting path guided his eye to Grisedale Tarn, lying in the pass from Patterdale to Grasmere. Here are four. Next, comes Grasmere, with Easedale Tarn above it, in its mountain hollow: then Rydal, of course, at his feet; and Elterwater beyond the western ridges; and finally, to the southwest, Esthwaite Water and Coniston. There are the ten. Eight of these may be seen at once from at least one point - Nab Scar, whence he must take his last complete survey; for from hence he must plunge down the steep slope, and bid farewell to all that lies behind the ridge. The day has gone like an hour. The sunshine is leaving the surface of the nearer lakes, and the purple bloom of the evening is on the further mountains; and the gushes of yellow light between the 


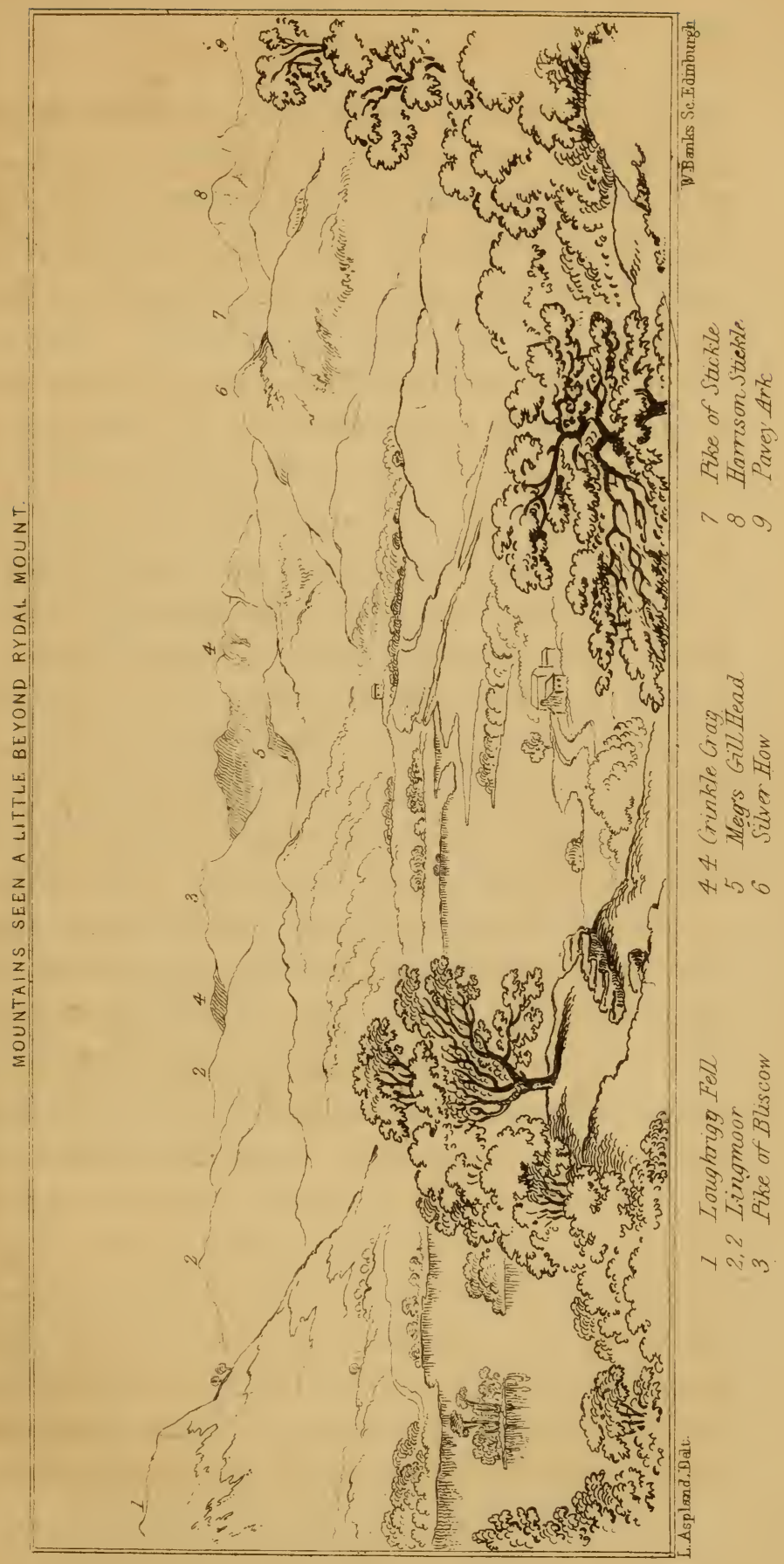



western passes show that sunset is near. He must hasten down, - mindful of the opening between the fences, which he remarked from below, and which, if he finds, he cannot lose his way. He does not seriously lose his way, though crag and bog make him diverge now and then. Descending between the inclosures, he sits down once or twice, to relieve the fatigue to the ancle and instep of so continuous a descent, and to linger a little over the beauty of the evening scene. As he comes down into the basin where Rydal Beck makes its last gambols and leaps, before entering the park, he is sensible of the approach of night. Loughrigg seems to rise : the hills seem to close him in, and the twilight to settle down. He comes to a gate, and finds himself in the civilised world again. He descends the green lane at the top of Rydal Mount, comes out just above Wordsworth's gate, finds his car at the bottom of the hill, - (the driver beginning to speculate on whether any accident has befallen the gentleman on the hills,) is driven home, and is amazed, on getting out, to find how stiff and tired he is. He would not, however, but have spent such a day for ten times the fatigue. $\mathrm{He}$ will certainly ascend Helvellyn, and every other mountain that comes in his way. 



\section{PART II.}

\section{KESWICK AND ITS ENVIRONS.}

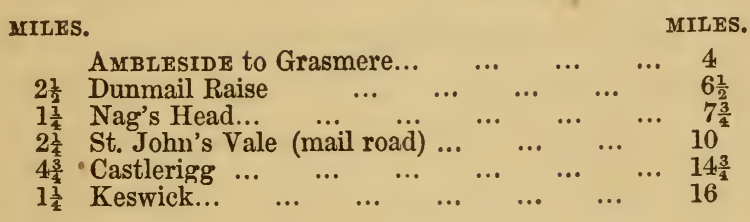

Some call Ambleside the head quarters of the lake district, and others Keswick. It is not necessary to settle this point of precedence here. Having treated of Ambleside first, because the tourist arrived there first, Keswick claims the next notice.

The road from Ambleside to Keswick has already fallen under our observation as far as Grasmere, and its conspicuous white inn, the Swan. That inn had the honour of providing Scott with a daily draught of something good, when he was, in his early days, the guest of Wordsworth and his sister at Grasmere, - their board being conscientiously humble, as they used to tell, to a degree, which did not suit the taste of their 
guest. By some device or another, Scott managed to pay a daily visit to the Swan without his friends being aware of it. But, when he, Wordsworth, and Southey were to ascend Helvellyn, mounting their ponies at the Swan, the host saw their approach, and cried out to Scott, "Eh, sir! you've come early for your drink today." It was a complete escape of the cat from the bag; but Wordsworth was not one to be troubled by such a discovery. No doubt he took the unlucky speech more serenely than his guest.

From the Swan, the road to Keswick ascends Dunmail Raise; - a steep pitch of road, though its highest point is only 720 feet above the sea. On the right there is a stream which divides the counties of Cumberland and Westmorland; and on either hand rise the mountains of Steel Fell and Seat Sandal. The cairn, - a rude mass of stones near the top of the ascent, which the stranger should be on the look out for, marks the spot of a critical conflict in the olden time,that is, in A.D. 945, - when the Anglo Saxon King Edmund defeated and slew Dunmail, the British King of Cumbria, and then put out the eyes of the two sons of his slain foe, and gave their inheritance to Malcolm, King of Scotland.

At the Nag's Head, the little inn which is about a mile and a-quarter further on, the traveller must decide on one of three courses, - as politicians are wont to do. He may go up Helvellyn, or he may bowl along on the high road, straight through Legberthwaite, and immediately under Helvellyn; or he may go on foot, or on a pony, round the western side of the lake, which is 



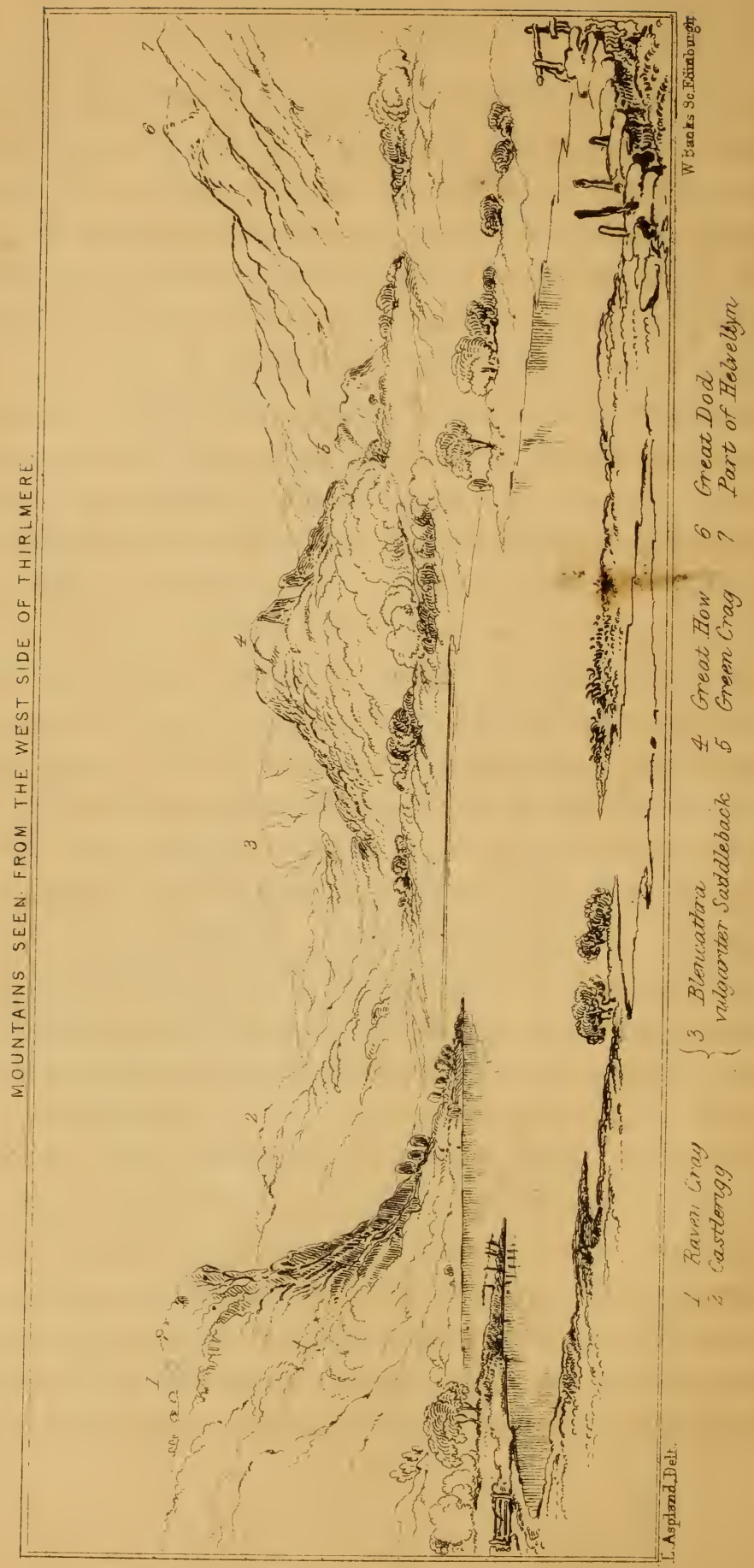


known by the various names of Wythburn Water, Leathes Water, and Thirlmere. It is a choice of pleasures; and he will ascend Helvellyn hereafter, if he does not now. Of the two lake roads, the rude western one is unquestionably the finest. The woods, which were once so thick that the squirrel is said to have gone from Wythburn to Keswick without touching the ground, are cleared away now ; and the only gloom in the scene is from the mass of Helvellyn. The stranger leaves the mail road within a mile of the Nag's Head, passes the cottages called by the boastful name of the City of Wyburn, and a few farm-houses, and soon emerging from the fences, finds himself on a grassy level under the Armboth Fells, within an amphitheatre of rocks, with the lake before him, and Helvellyn beyond, overshadowing it. The rocks behind are feathered with wood, except where a bold crag here, and a free cataract there introduces a variety. There is a clear pool in the midst of the grass, where, if the approaching tread be light, the heron may be seen fishing, or faithfully reflected in the mirror. The track leads by the margin of the lake, and through a shady lane, and a farm yard, to the bridge by which the lake is to be crossed. The water is shallow there, between two promontories; so that piers are easily built, with little wooden bridges at intervals: and thus is solved what is to novices a great mystery; - how there can be a bridge over a lake. There is another mystery just behind, under the Armboth Fells, - a haunted house. Lights are seen there at night, the people say; and the bells ring; and just as the bells all set off ringing, a large 
dog is seen swimming across the lake. The plates and dishes clatter; and the table is spread by unseen hands. That is the preparation for the ghostly wedding feast of a murdered bride, who comes up from her watery bed in the lake to keep her terrible nuptials. There is really something remarkable, and like witchery, about the house. On a bright moonlight night, the spectator who looks towards it from a distance of two or three miles, sees the light reflected from its windows into the lake; and, when a slight fog gives a reddish hue to the light, the whole might easily be taken for an illumination of a great mansion. And this mansion seems to vanish as you approach, - being no mansion, but a small house lying in a nook, and overshadowed by a hill. The bridge being crossed, another bit of lane leads out upon the high road near the clean little inn, the King's Head, and within view of the vale of St. John.

One would like to know how often the Bridal of Triermain has been read within that vale. The Castle Rock, in its disenchanted condition, is a prominent object in approaching the vale from Legberthwaite, or by the road just described; and there are lights and gloomy moments in which it looks as like as may be to a scene of witchery, - now engrossing the sunshine when the range to which it belongs is all in shadow; and now perversely gloomy, because there is a single cloud in the sky. The narrow vale is full of character and charm, from end to end ; and at its northern extremity it comes out upon a spot of strong historical interest. The village of Threlkeld will, by its name, remind the traveller of the good Lord Clifford, the story of 


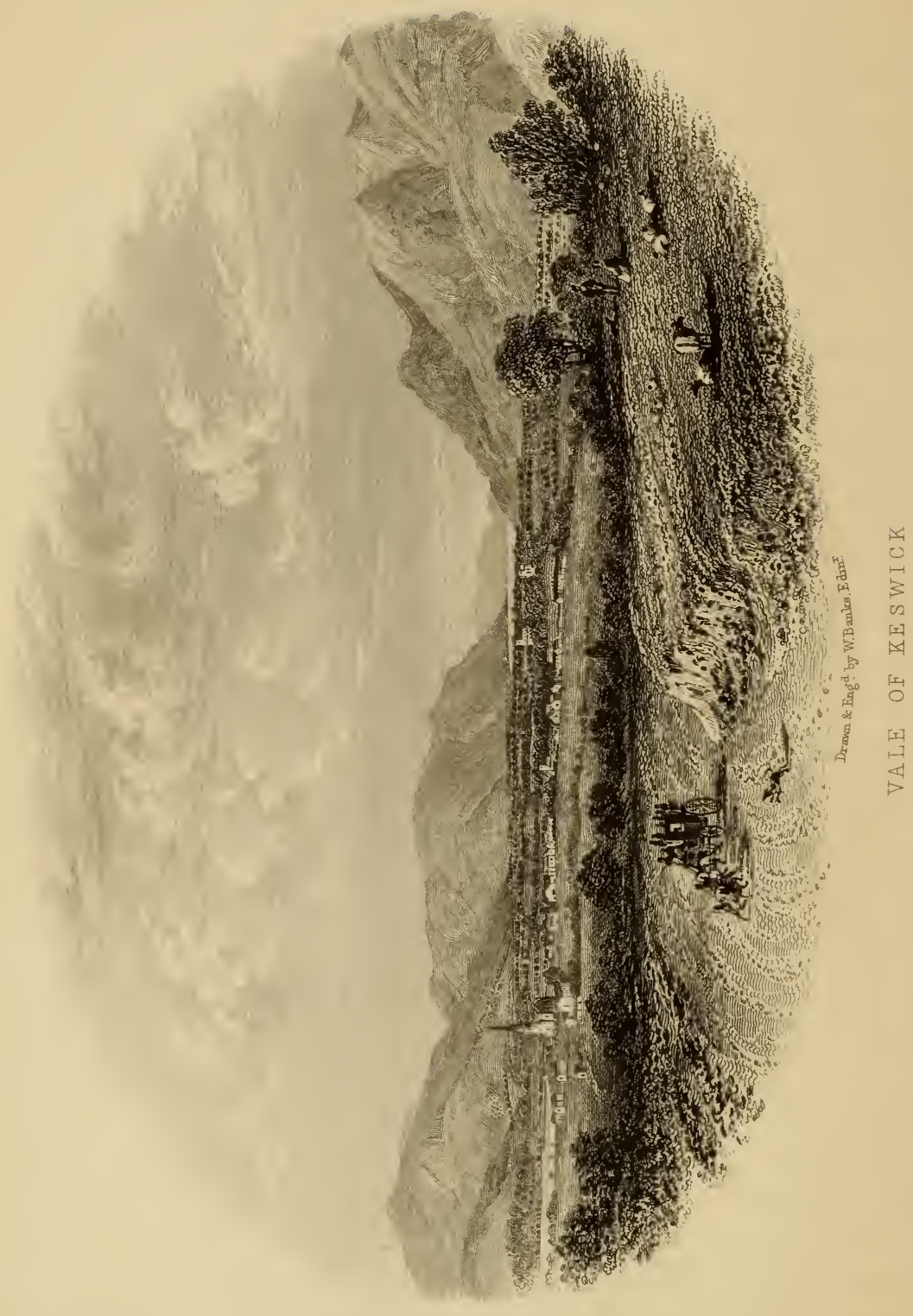


whose boyhood is familiar to all readers of Wordsworth. That place is, indeed, the refuge where the boy passed his shepherd life; and there is a local tradition that, though he never learned to read or write, during the twenty-four years that he spent in keeping sheep, his astronomical knowledge was considerable, and so interesting to him that he improved it by study after he came to his estates. The road through Threlkeld will, however, be followed by the traveller on another occasion, and not now : for he must not miss that view from Castlerigg, which made the poet Gray long to go back again to Keswick; and he will not, therefore, now pass through the vale. Within five miles from the peep into it, the view opens, which presently comprehends the whole extent from Bassenthwaite Lake to the entrance of Borrowdale; - the plain between the two lakes of Bassenthwaite and Derwent Water, presenting one of the richest scenes in England, - with the town of Keswick, and many a hamlet and farmstead besides ; and the two churches, - the long, white, old-fashioned Crosthwaite church, in which Southey is buried, and the new red-stone church of St. John, with its spire, and the school houses and pretty parsonage at hand. These were built by the late John Marshall, of Hallsteads, a name which is more spoiled than dignified by any conventional addition. The church and parsonage were occupied by the husband of one of his daughters; and now heand his son-in-law lie buried there together. Skiddaw is here the monarch of the scene. That mountain mass occupies the north of the view. Bassenthwaite lake peeps from behind it : then the plain of the Derwent 
stretches out to the lake of that name; and at the southern end the Borrowdale mountains are grouped with wonderful effect,-Castle Crag occupying the most conspicuous place. On the eastern side, to the left of the spectator, Wallabarrow Crag rears its crest, and unfolds its woods below; while the opposite side of the lake is guarded by Cat Bells and other mountains, bare and pointed, and possessing a character of their own. A steep winding road descends into the valley; and at the foot of the hill lies Keswick.

There is no beauty in the primitive little town itself; but it has its attractions, besides the convenience of its central situation among so many mountains and valleys. Of these attractions, the first is, undoubtedly, Mr. Flintoft's Model of the Lake District, which is within a few yards of all the principal inns, and may be seen during a shower, when, otherwise, the stranger might be losing temper in hearing the rain drip. That model, - at first sight an uneven ugly bit of plaster, - will beguile a sensible traveller of a longer time than he would suppose possible. Ten minutes would give him a better idea of the structure and distribution of the country than all maps and guide books; but he will probably linger over it till he has learned all the sixteen large lakes, and some of the fifty-two small ones, and traced every road and main pass in the district. Crosthwaite's Museum is also a place of great interest, for its own sake, as well as that of its founder, - Peter Crosthwaite, the first real explorer, surveyor and draughtsman of the district, and the inventor of the æolian harp, the lifeboat (the reward of which invention he missed through 
carelessness in a government office,) and various other matters, useful or curious. The museum contains ancient coins, ancient books, and a good geological and mineralogical collection. It was begun between 70 and 80 years ago ; and the founder died in 1808 . It is preserved, improved and exhibited by his descendants.

The inns of Keswick are numerous. The chief are the Royal Oak, the Queen's Head, and the King's Arms, - all good. 


\section{EXCURSIONS FROM KESWICK.}

DERWENT WATER,

The first object of attention will be the lake itself; and it will probably be viewed by boat. The uppermost thought at all points about the foot of the lake is of the Derwentwater family. They had once a castle on the hill called Castlehead, where they built upon the site of a Druidical circle. This hill should be visited for the view. The Ratcliffes also possessed Lord's Island, the largest on the lake, where their mansion is said to have been built, from the stones of the old one on Castlehead. Ramps Holme, another of the islands, was their's also; and the hermit, the dear friend of St. Cuthbert, who lived in St. Herbert's Isle in the seventh century, is somehow mixed up in legends, in local imaginations which are careless of dates, with the same family. All that is known of St. Herbert is, that he really had a hermitage in that island, and that St. Cuthbert and he used to meet, either at Lindisfarn or Derwentwater, once a-year. The legend about their deaths is well known; that, according to their prayer, they died on the same day. There is beauty in the tradition that the man of action and the man of meditation, the propagandist and the recluse, were so dear to each other, and so congenial. Vicar's, or 


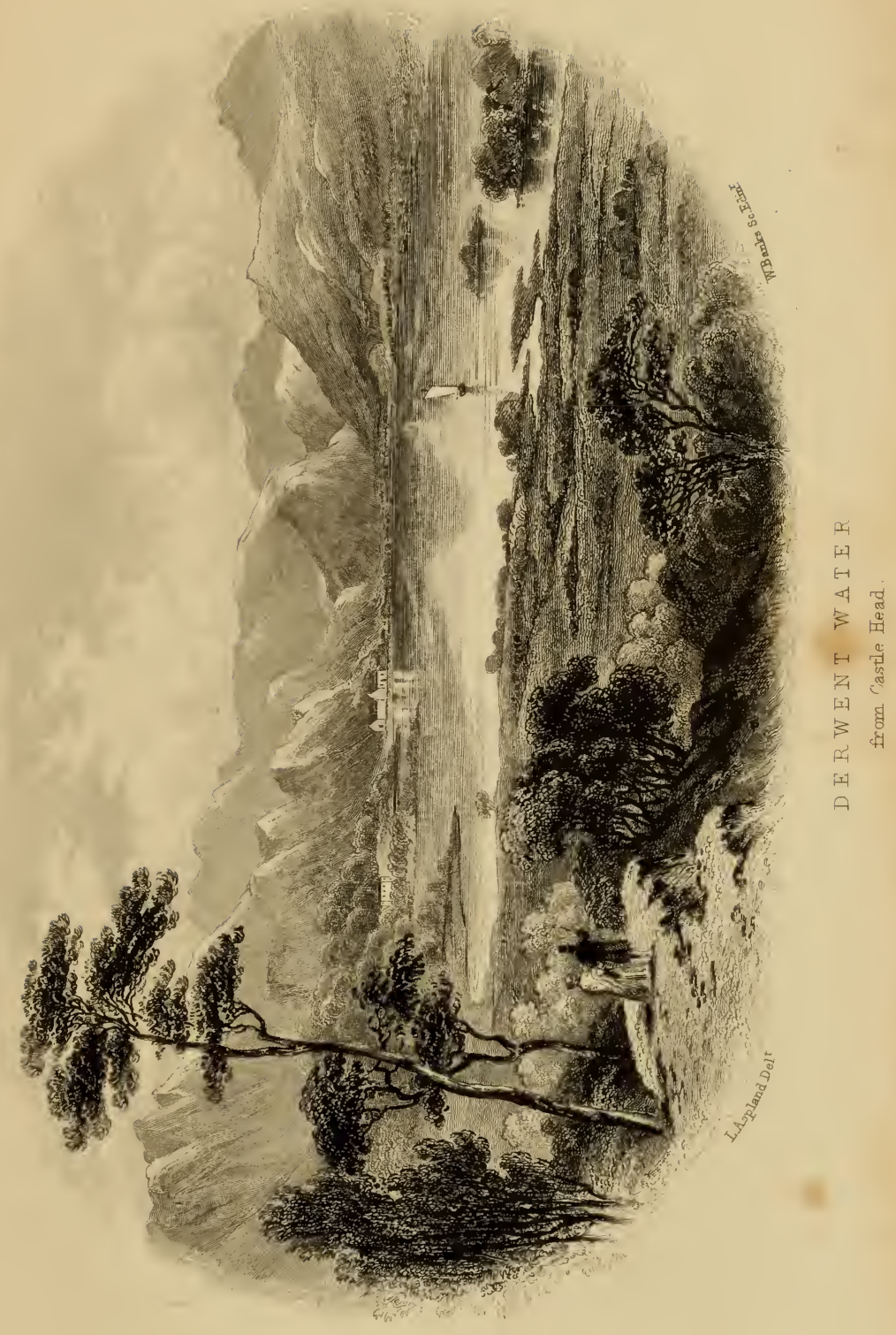



Derwent Isle, is the other of the four larger islands. Lord's Isle was once a part of the mainland. The Ratcliffes cut a fosse, in the feudal times, and set up a drawbridge. When the young Lord Derwentwater was captured for being "out" in 1715, his lady escaped, and saved her liberty and the family jewels (to use them on behalf of her husband) by clambering up one of the clefts of Wallabarrow Crag, since called the Lady's Rake. Every where are there traces of the unhappy family; even in the sky, where the aurora borealis is sometimes called, to this day, Lord Derwentwater's lights, because it was particularly brilliant the night after his execution.

The lake is about three miles long, and, at its broadest part, about a mile and a half wide. Its waters are singularly clear, and its surface often unruffled as a mirror. Then it reflects the surrounding shores with marvellous beauty of effect, - from the bare crest of the crag and peak of the mountain to the grassy knoll and overhanging birch. Pike, trout, and perch abound in the lake; but not char, which requires deeper water. The Floating Island, whose appearance is announced in the newspapers at intervals of a few years, has obtained more celebrity than it deserves. It is a mass of soil and decayed vegetation, which rises when distended with gases, and sinks again when it has parted with them at the surface. Such is the explanation given by philosophers of this piece of natural magic, which has excited so much sensation during successive generations . Sometimes it comes up a mere patch, and sometimes measuring as much as an acre. 
FIRST TOUR.

WATENDLATH, BORROWDALE, ROSTHWAITE, GRANGE, IODORE.

\begin{tabular}{|c|c|c|c|c|c|c|c|c|c|}
\hline $\mathrm{HL}$ & & & & & & & & & IIL \\
\hline & KESWICK to & $\mathrm{Wa}$ & endlath & Roar & & & & $\cdots$ & $1 \frac{3}{2}$ \\
\hline $3 \frac{2}{4}$ & Watendlath & $\cdots$ & $\ldots$ & & $\ldots$ & & $\cdots$ & & 5 \\
\hline 2 & Rosthwaite & & ... & $\cdots$ & &.. & & $\ldots$ & 7 \\
\hline 3 & Lodore & $\cdots$ & ... & & $\cdots$ & & $\ldots$ & & 10 \\
\hline 3 & Keswick ... & & $\ldots$ & $\ldots$ & & $\ldots$ & & $\ldots$ & 13 \\
\hline
\end{tabular}

If the tourist desires, (as it is to be hoped that he does) to see one of the primitive valleys of the district, - one of those recesses lapped in the mountains, where the sounds of civilised life have hardly penetrated, let him now go to Watendlath (locally called Wathendal) and descend into Borrowdale by Rosthwaite. The circuit is one of 13 miles; and it must be accomplished on foot or horseback; for there is no carriage-road in the upper part. So few pass that way that the women afford a remarkable specimen of the effects of a life of excessive seclusion. The men go to markets and sales, and have more use of their tongues and wits accordingly. The road along the lake side is followed, till it gives out a branch before reaching Barrow House. Up this by-road the explorer goes, and passes behind and above Barrow House, soon reaching the stream that feeds the Barrow fall, which may be visited by strangers in the grounds below. The upland valley runs parallel with the lower one; and in it lies the clear circular pool which feeds the fall of Lodore. Stout pedestrians say 
that the walk over the trackless heather, turning to the left, over the fells to Thirlmere, is glorious in a fine autumn day. No doubt it is : but our business now is to follow the track before us. It takes us to the little foot-bridge between the tarn and the verge of the crag; and the peep down the chasm shows the lake and the Skiddaw range in beautiful union. Helvellyn rises to the east, and Scawfell and Bowfell show themselves in front, all the way down into Borrowdale. The descent upon Rosthwaite is the concluding treat. The way is easy, - a gentle slope over grass and elastic heather; and the whole surface is starred over with bright heath flowers. The head of the dale, imposing under all aspects, opens out, and seems to be spreading its green levels for the stranger's rest. The passes to Langdale by the Stake, to Wastdale by Sty Head, and to Buttermere by Honister Crag, disclose themselves round the projecting Glaramara. The other way lie Grange and the Lake; and beneath lies Rosthwaite, with the brattling stream behind, which must be crossed by steppingstones to reach the little inn. Before turning his face lakewards, the traveller must go forward a few yards from Simpson's inn, to where he will see a narrow entrance and steps in the right-hand fence. He must go in there, and mount that little hill, called Castlehill, whence the truest and best total view of Borrowdale is obtained; for the station is nearly central.

He is now standing in the middle of that far-famed Borrowdale, of which so many curious tales are told. Its inhabitants were once considered as primitive as we now consider those of Watendlath; and a good deal 
more, if the current stories are true. It is said that an old Borrowdale man was once sent a very long way for something very new, by some innovator who had found his way into the dale. The man was to go with horse and sacks (for there were no carts, because there was no road) to bring some lime from beyond Keswick. On his return, when he was near Grange, it began to rain; and the man was alarmed at seeing his sacks begin to smoke. He got a hatful of water from the river; but the smoke grew worse. Assured at length that the devil must be in any fire which was aggravated by water, he tossed the whole load over into the river. That must have been before the dalesmen built their curious wall; for they must have had lime for that. Spring being very charming in Borrowdale, and the sound of the cuckoo gladsome, the people determined to build a wall to keep in the cuckoo, and make the spring last for ever. So they built a wall across the entrance, at Grange. The plan did not answer; but that was, according to the popular belief from generation to generation, because the wall was not built one course higher. It is simply for want of a top course in that wall that eternal spring does not reign in Borrowdale. Another anecdote shows, however, that a bright wit did occasionally show himself among them. A "statesman" - (an "estatesman," or small proprietor) - went one day to a distant fair or sale, and brought home what neither he nor his neighbours had ever seen before;-a pair of stirrups. Home he came jogging, with his feet in his stirrups; but, by the time he reached his own door, he had jammed his feet in so fast that they would not come 
out. There was great alarm and lamentation; but, as it could not be helped now, the good man patiently sat his horse in the pasture for a day or two, his family bringing him food, till the eldest son, vexed to see the horse suffering by exposure, proposed to bring both into the stable. This was done; and there sat the farmer for several days, - his food being brought to him, as before. At length, it struck the second son that it was a pity not to make his father useful, and release the horse; so he proposed to carry him, on the saddle, into the house. By immense exertion it was done; the horse being taken alongside the midden in the yard, to ease the fall: and the good man found himself under his own roof again, - spinning wool in a corner of the kitchen. There the mounted man sat spinning, through the cleverness of his second son, till the lucky hour arrived of his youngest son's return, - he being a scholar, - a learned student from St. Bees. After duly considering the case, he gave his counsel. He suggested that the goodman should draw his feet out of his shoes. This was done, amidst the blessings of the family ; and the goodman was restored to his occupations and to liberty. The wife was so delighted that she said if she had a score of children, she would make them all scholars, - if only she had to begin life again.

It is by no means to be supposed, however, that there was no wit in the valley, but what had come from St. Bees. On the contrary, a native genius, on one occasion, came to a conclusion so striking that it is doubtful whether any university could rival it. A stranger came riding into the dale on a mule, and, being 
bound for the mountains, went up the pass on foot, leaving the animal in the care of his host. The host had never seen such a creature before, nor had his neighbours. Fearing mischief, they consulted the wise man of the dale; for they kept a Sagum, or medicine man, to supply their deficiencies. He came, and after an examination of the mule, drew a circle round it, and consulted his books while his charms were burning; and, at length, announced that he had found it. The creature must be, he concluded, a peacock. So Borrowdale could then boast, without a rival, of a visit from a stranger who came riding on a peacock. There is a real and strong feeling in the district about these old stories. Only last year, when a Borrowdale man entered a country inn, a prior guest said simply "cuckoo," and was instantly knocked down; and a passionate fight ensued. This cannot last much longer, - judging by the number of new houses, - abodes of gentry, - built or building in Borrowdale. The wrath must presently turn to a laugh in the humblest chimney corner in the dale.

Rosthwaite is beautifully situated near the centre of the dale, and at the confluence of the two mountain brooks which form the Derwent. This river flows through the lakes of Derwent Water and Bassenthwaite, passes Cockermouth, and falls into the sea at Workington. Following its course, the traveller reaches the Bowder Stone at a mile from Rosthwaite, - a fallen rock, standing on its point, and about thirty feet high, and sixty long. There are steps for ascent to the top; but it is as well seen from below, where it cannot but 
catch the eye of the passenger. A mile further lies Grange, at the entrance of the dale, with its undulating bridges crossing the windings of the river. When the Abbots of Furness owned the whole of Borrowdale, a few monks were placed at its entrance, to receive and guard the crops; and this place was their granary. It is now a picturesque hamlet, which must be familiar to all who haunt exhibitions of pictures. Nobody who carries a pencil can help sitting down on the grass to sketch it. Just behind it, the noble wooded rock, which leaves room only for the road and the river, is Castle Crag; and nimble youths who have reached its summit, say the view is splendid. It is, in itself, a fine spectacle.

After this, the traveller begins to listen for the fall of Lodore, and he finds the inn at the distance of a mile from Grange. It is a delighful little inn, clean and well managed, and, by its situation, preferable to those at Keswick, except for the convenience of headquarters. To visit the fall, the way is through the gay little garden, and the orchard, (where the fish-preserves are terrible temptations to waste of time) and over a foot bridge, and up into the wood, where the path leads to the front of the mighty chasm. It is the chasm, with its mass of boulders and its magnificent flanking towers of rock, that makes the impressiveness of the Lodore fall, more than the water. No supply short of a full river or capacious lake could correct the disproportion between the channel and the flood. After the most copious rains, the spectacle is of a multitude of little falls, and nowhere of a sheet or bold shoot of 
water. The noise is prodigious, as the readers of Southey's description are aware: and the accessaries are magnificent. Gowder Crag on the left, and Shepherd's Crag on the right, shine in the sun or frown in gloom like no other rocks about any of the falls of the district; and vegetation flourishes every where, from the pendulous shrubs in the fissures, 200 feet overhead, to the wild flowers underfoot in the wood. On a lustrous summer evening, when the lights are radiant, and the shadows sharp and deep, the scene is incomparable, whatever may be the state of the water. When the stream is fullest, and the wind is favourable, it is said the fall is heard a distance of four miles. There is something else to be heard here; and that is the Borrowdale echoes. A cannon is planted in the meadow before the inn, which awakens an uproar from the surrounding crags to Glaramara.

The road from Lodore to Keswick, about three miles, runs between the lake and the Wallabarrow and Falcon Crags. It is a charming walk in all seasons, - sheltered in winter, shady, for the most part, in summer ; and in spring and autumn presenting a vast variety of foliage, bursting forth or fading. 


\section{SECOND TOUR.}

BY THE VALE OF NEWLANDS, CRUMMOCK WATER, SCALE HILL INN, AND BACK BY WHINLATTER.

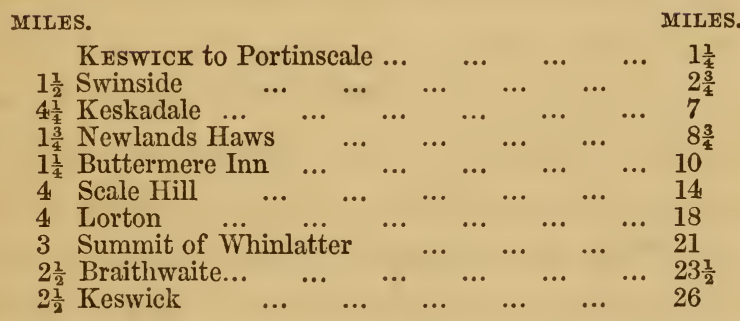

The tour which embraces the country between the four lakes, Derwent Water, Buttermere, Crummock Water, and Bassenthwaite, is one of twenty-six miles; and it should be allowed to occupy the greater part of a day, - time being taken both for survey and refreshment. Its outset will afford a good opportunity for visiting Greta Hall, Southey's abode, and his monument in Crosthwaite Church;-a recumbent statue by Lough, - the inscription being written by Wordsworth. The villages along the road, beginning with Portinscale, will exhibit their own evidence of the employment of the inhabitants in the woollen manufacture; an ancient staple of the town and district, as is shown by the inscription which has come down from the olden time, engraved on a flagstone.

"May God Almighty grant His aid

To Keswick and its woollen trade." 
Afterwards, the views over the rich plain, and glimpses into fertile valleys are charming, till the road winds in among what the oldest guide-books truly call the solemn pastoral scenes that open after leaving Keskadale. The houses of Keskadale are the last seen before entering on the ascent of Newlands Haws. The vale formed by the rapid slope of mountains that are bare of trees, boggy in parts, and elsewhere showing marks of winter slides, is wholly unlike any thing else in the district. Its silence, except for the bleating of sheep; its ancient folds, down in the hollow, the length and steepness of the ascent, and the gloom of the mountain, - Great Robinson, with its tumbling white cataract, - render this truly "a solemn pastoral scene." At the head of the vale, it is found not to be shut in. A turn to the right discloses a new landscape. A descent between green slopes of the same character leads down directly upon Buttermere. The opposite side of the hollow is formed by the mountain Whitelees. The stream at the bottom flows into Crummock Water; and the four peaks of High Crag, Hayrick, High Stile, and Red Pike, are ranged in front.

The Lake of Buttermere and Honister Crag must be left for another day. To-day, the turn is to the right, and not the left. The traveller may proceed along Crummock Water either by boat or in his carriage. Or he may leave the horse to bait at Buttermere while he takes a boat to see Scale Force, and returns.

The meadow between the two lakes is not more than a mile in extent. The walk to the boat lies through its small patches of pasture and wooded knolls; and a 


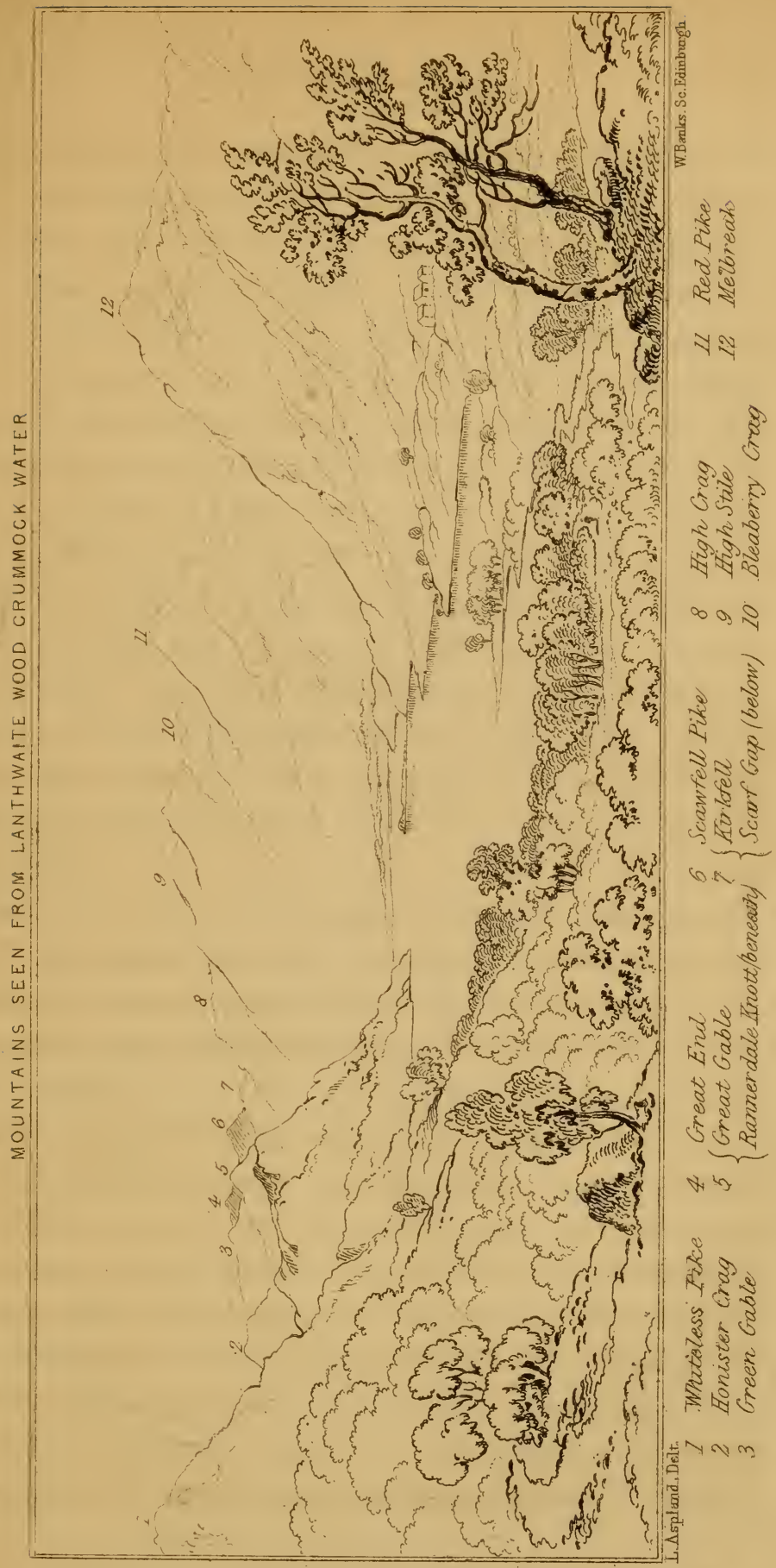



pretty walk it is. The path is prolonged to Scale Force over the fields; but it is usually too swampy to be agreeable, when a boat can be had. A short row brings the stranger to the mouth of the stream from the force; and he has then to walk a mile among stones, and over grass, and past an old fold. The chasm between two walls of rock, which are feathered with bright waving shrubs, affords a fall of 160 feet, high enough to convert the waters into spray before they reach the ground. It is one of the loftiest waterfalls in the country; and some think it the most elegant. There is a point of view not far off which the traveller should visit. His boat will take him to the little promontory below Melbreak, called Ling Crag. From 200 yards, or rather more, above this, he will see two lakes and their guardian mountains to the greatest advantage.

The drive along Crummock Water is one of the most charming we know; especially where the road forms a terrace, overhanging the clear waters, and sweeping round Rannersdale Knot. Melbreak fills up the opposite shore, with its isolated bulk; and Red Pike discloses its crater; both being streaked with red and lead-coloured screes, and tracts of bright verdure and darker moss. On the side where the road is, Whitelees, Grassmoor, and Whiteside rear their swelling masses; and the road winds pleasantly among fields and meadows, till it passes behind the Lanthwaite Woods, and turns down, in full view of the rich Vale of Lorton, to Scale Hill Inn. That best and most home-like of inns should be the traveller's resting 
place for days together, if he desires a central point whence he may visit a great extent of the lake country, while in command of a variety of pleasures near at hand. From Scale Hill he can descend into the vale of Lorton, and enjoy a change from the ruggedness of the dales. Or, he may visit the most solemn and imposing of the lakes, - Wast Water; and also Ennerdale. He commands all the roads to Keswick, and the vales that lie between. Crummock Water yields char, as well as every other lake fish, in abundance. The mountain tops are accessible: from Lowfell, which may be a lady's morning walk, to Red Pike, which is a pretty good day's scramble for a stout student. There is Lowes Water at one end of Crummock, and Buttermere at the other: and at home there is a spacious, clean, airy house, standing in a garden; good fare, careful attendance, and reasonable charges. Scale Hill is a place to spend a month in, in a fine season.

A few minutes will take the stranger up to the Station, by a path from the inn door. The Station is a hill in Lanthwaite Wood, whence a magnificent view is obtained of the stern mountain group, (the central group of the whole district,) on the one hand, and the rich levels of Lorton Vale on the other, backed, in favourable lights, by the Scotch mountains. This spot is one on which to linger through a long summer day, pacing the sward, and choosing seats from rock to rock, along the whole crest. The stranger must now, however, take his brief survey, and hope to come again. He has twelve miles to go to Keswick; and 
the early part of it is steep and slow. The turn is to the right, at about a mile from scale Hill, leaving the Cockermouth road, which traverses the vale of Lorton. The higher he ascends, the more lovely are the views over that vale that the traveller obtains, till at length the Solway gleams in the sun, and the Scotch mountains appear beyond. If he has good eyes, the driver will point out to him, at a vast distance, the famous old Lorton yew, appearing like a dark clump, beside a white farmhouse. When fairly under Whinlatter, six or seven miles from Scale Hill, he cannot but admire, - in one or the other sense of the word, - the colouring of the hill itself, if the time be anywhere from June to September. The gaudy hues of the mingled gorse and heather are, at that season, unlike any exhibition of colour we have seen elscwhere, - exceeding even the far-famed American forest. As the north-western vision vanishes, the south-eastern opens ; and the vale of Keswick, with Skiddaw in its noblest aspect, and the lakes far below, looks finer than ever. After passing through Braithwaite, he soon recognises the road, and returns to Keswick by the well-known bridge over the Derwent. 


\section{THIRD TOUR.}

\section{CIRCUIT OF BASSENTHWAITE.}

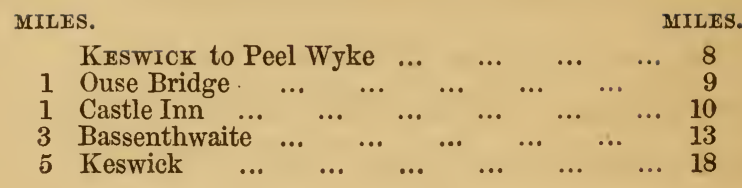

Bassenthwaite is perhaps the last of the lakes to be visited, unless it be Hawes Water. Hawes Water is difficult of access to the ordinary tourist: and Bassenthwaite verges towards the flat country, which is not what the traveller came to visit. It is amusing to observe how the residents in the district become more sensible every year to the beauty of the merely undulating country through which the mountains sink into the plains : while strangers have hardly patience to look at it, in their eagerness to find themselves under the shadow of the great central fells. Bassenthwaite is one of the outermost lakes; and it is therefore no more cared for by the tourists in general than the foot of Coniston or Windermere. Still, considering that Skiddaw overshadows its eastern shore, it would seem worthy of some attention; and the drive of eighteen miles round it is, in truth, a very pleasant one.

This lake is larger than Derwent Water, being four miles in length and one mile in breadth. The distance 
from lake to lake is between three and four miles, a large proportion of which is apt to be flooded in winter ; and occasionally the waters actually join, so as to present the appearance of a lake of ten miles long, the length of Windermere. These floods are a serious drawback to the productiveness of the lake levels, and the health and comfort of the inhabitants.

The side opposite Skiddaw is the most interesting of the two; so the traveller takes it first. The road passes through Portinscale and Braithwaite to Thornthwaite, and leaves Whinlatter on the left. It passes through woods and pretty glades which make a charming foreground, while old Skiddaw fills the view on the opposite shore. Lord's Seat and Barf rise boldly to the left, and the road runs, for the most part, on the margin of the lake. It winds round, after passing Peel Wyke, to Ouse Bridge, beneath which the lake discharges itself in the form of the much enlarged river Derwent, which flows away towards Cockermouth. If it is thought worth while to go a mile or two out of the way for an exceedingly fine view, the traveller will follow the Hesket road for a mile beyond Castle Inn, and ascend the Haws on the right. Thence he will see a charming landscape, - the open vales of Embleton and Isell, and the whole expanse of the lake, with its rich terraced shores. From Castle Inn, it is eight miles to Keswick. The road turns away from the lake, and presents nothing more of remarkable beauty. 


\section{FOURTH TOUR.}

ASCENT OF SKIDDAW.

The ascent of Skiddaw is easy, even for ladies, who have only to sit their ponies to find themselves at the top, after a ride of six miles. There must be a guide, - be the day ever so clear, and the path ever so plain. Once for all let us say, in all earnestness, and with the most deliberate decision, that no kind of tourist should ever cross the higher passes, or ascend the mountains, without a guide. Surely, lives enough have been lost, and there has been suffering and danger enough, short of a fatal issue, to teach this lesson. But the confident and joyous pedestrian is not the most teachable of human beings. In his heart he despises the caution of native residents, and in his sleeve he laughs at it. The mountain is right before him; the track is visible enough; he has a map and guide book, and boasts of his pocket-compass. With the track on his map, and track on the mountain, both before his eyes, how should he get wrong? So he throws on his knapsack, seizes his stick, and goes off whistling or singing, - the host and hostess looking after him and consulting as he strides away. For some time he thinks he can defy all the misleading powers of heaven and earth. But, once out of reach of human help, he finds his case not quite so easy as he thought. Instead of one path, as marked 
on his map, he finds three; and perhaps the one he relies on may have disappeared under recent accidents, or have lapsed into swamp. He finds himself on the edge of a precipice, and does not know how far to go back. He finds the bog deepen, and thinks he can scarcely be in the right road. He finds a landslip, which compels him to make a wider circuit, and meantime it is growing dusk. Worst of all, a fog may come on at any moment; and there is an end of all security to one who does not know the little wayside-marks which guide the shepherd in such a case. Tales are current throughout the region of the deaths of natives, even in the summer months, through fog, wet, fatigue, or fall, - the native having a better chance than a stranger, ten times over. And why should the risk be run? It cannot be to save the fee, in the case of a journey of pleasure. The guide is worth more than his pay for the information he has to give, - to say nothing of the comfort of his carrying the knapsack, - as many knapsacks as there are walkers. If solitude be desired, the meditative gentleman will soon find that anxiety about the way, and an internal conflict with apprehensiveness are sad spoilers of the pleasures of solitude. Better have a real substantial, comfortable, supporting shepherd by his side, giving his mind liberty for contemplation and enjoyment of the scene, than the spectres of the mountain perplexing him on all sides, and marring his ease. But enough. Travellers who know what mountain climbing is, among loose stones, shaking bog, and slippery rushes or grass, with the alternative of a hot sun or a strong wind, and perpetual 
liability to mist, will not dispute the benefit of having a guide : and novices ought to defer to their judgment. If we have seemed to dwell long on this point, it is because warning is grievously wanted. It will probably not be taken by those who need it most; but it ought to be offered.

Even in the mild ascent of green Skiddaw, then, there is a guide. - At the distance of half-a-mile from Keswick, on the Penrith road, just through the tollbar, a bridge crosses the Greta. The road, after crossing this bridge, winds round Latrigg, and in the direction of Low Man, crossing the barren plain called Skiddaw Forest. The plain of Keswick, and the lake and its islands, grow smaller and smaller, and the surrounding mountains seem to swell and rise, as the road gently climbs the side of Skiddaw; and, when about half way up, that lower world disappears, while a more distant one comes into view. The Irish Sea and the Isle of Man rise, and the Scotch mountains show themselves marshalled on the horizon. At the first summit, after a mile of craggy ascent, steeper than the rest, the city of Carlisle comes into view, with the coast and its little towns, round to St. Bees, with the rich plains that lie between. But there is a higher point to be reached, after an ascent of 500 feet more; and here Derwentwater comes into view again. And how much besides! Few lakes are seen; but the sea of mountain tops is glorious; and the surrounding plains ; and the ocean beyond ; and land again beyond that. In opposite directions, lie visible, Lancaster Castle and the hills of Kirkcudbright, Wigton and 



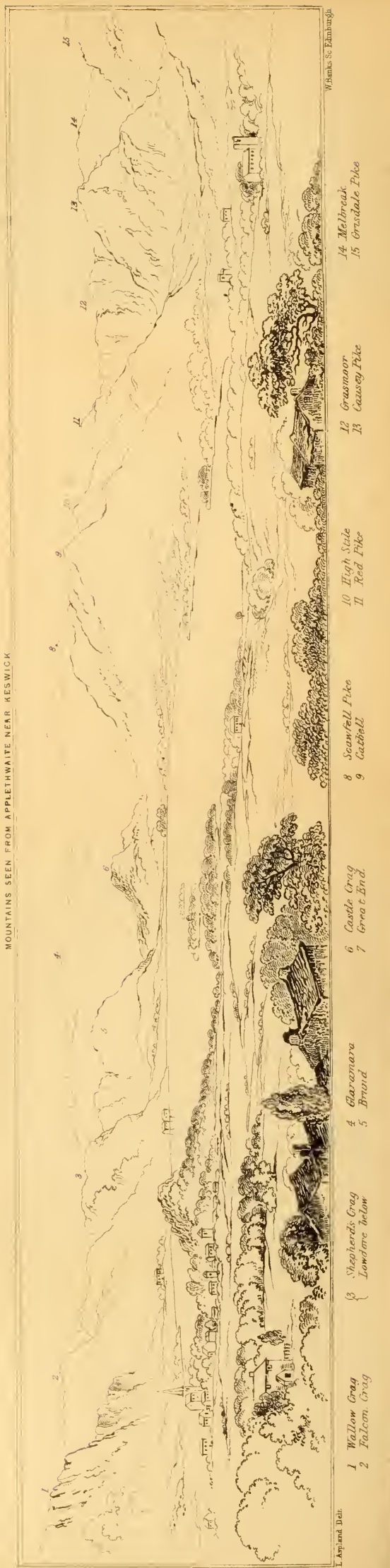


Dumfries. Lancaster Castle and Carlisle Cathedral in the same landscape! and Snowdon and Criffel nodding to each other! Ingleborough, in Yorkshire, looking at Skiddaw over the whole of Westmorland that lies between; with the Isle of Man as a resting place for the glance on its way to Ireland! St. Bees Head, with the noiseless waves dashing against the red rocks, being almost within reach as it were! And, as for Scawfell, Helvellyn, and Saddleback, thay stand up like comrades, close round about. Charles Lamb was no great lover of mountains: but he enjoyed what he saw here. "O! its fine black head," he wrote of Skiddaw, "and the bleak air atop of it, with a prospect of mountains all about and about, making you giddy; and then, Scotland afar off, and the border countries, so famous in song and ballad! It is a day that will stand out like a mountain, I am sure, in my life!" "Bleak" the air is indeed "atop,"- exposed as the summit is to the seawinds. If the stranger desires to take a leisurely view, he must trouble his guide or his pony with a railway wrapper, or something of the sort, to enable him to stand his ground. The descent may be made, for the sake of variety, by a road through Milbeck and the pretty village of Applethwaite; or by descending the north side of the mountain, and coming out upon the road, just north of the village of Bassenthwaite. 


\section{FIFTH TOUR.}

ASCENT OF SADDLEBACK.

An expedition to Saddleback affords a good opportunity for visiting the Druids' Temple, a mile and a-half from Keswick. This very well-preserved memorial of antiquity stands in a field, near the entrance of St. John's Vale. 'The stones, forty-eight in number, form an oval; and there is a peculiarity in this case which distinguishes it from all other Druidical monuments extant in England. On the eastern side, within the circle, there is a small recess formed by ten stones, making an oblong square. As Southey observed, the spot is the most commanding that could be chosen, short of a mountain side; and it is indeed nearly surrounded by mountains, which it recognises in their true forms, from the levels, - with the exception of the plain towards Penrith, - being sunk out of view. The old legend about the last human sacrifice of the Druids may belong to any of the monuments of that age in the district; and it is probably claimed for them all. According to that old story; when some people settled in a clearing of the woods, beside a river, somewhere to the south of the district, the priests took up their station further north, among the mountains, where there were plenty of stones fit and ready for their temple. After a time, a fever laid waste the lower 
settlement; and the oracle demanded a sacrifice to appease the divine wrath. The lot fell on a young girl who was betrothed: and, on an appointed day, she was conveyed, with all the ceremonies, to the temple. A small hut of wickerwork, like a large beehive, was found set up on the western side of the temple. The girl was led into the circle, and placed in the midst, while the dedication proceeded. We are even told that she was adorned with an oak garland, and held mistletoe in her hand. The whole population was looking on from a distance: but it must have been within reasonable reach, as every one was required to contribute a stick to the fire. The wretched lover saw all from afar; and he daringly resolved, - let the god be as wrathful as he pleased, - not to contribute so much as a twig to the burning of his beloved. She was seen to enter the door, which was next the circle; and then the priest closed it up, and heaped the dried leaves and sticks that were brought all round the hut. The arch-druid meantime was procuring fire from two pieces of wood. $\mathrm{He}$ succeeded, and set the pile in a blaze. In this moment of desperation, the lover saw every mountain round give forth a great cataract; and all the floods gushed to the temple as to a centre, and made an island of the little hut, - returning when they had extinguished the fire. The victim came forth, with not a hair singed, and not a leaf of her garland withered. The archdruid, skilled to interpret thunder, seems to have understood in this case the voice of waters; for he announced that, henceforth, the god would have no more human sacrifices. Any resident who is sufficiently familar with 
the country people to get them to speak their minds fully, will find that they still hold to the notion that nobody can count the druid stones correctly; and also that a treasure is buried under the largest stone. As to the first, - there are, in most such circles, some smaller stones cropping out of the ground which some visitors will, and others will not, include among those of the circle. We ourselves counted Long Meg and her daughters, near Penrith, many times before making out the prescribed sixty-seven, with any certainty. As for the treasure, can any one prove that it is not there? Nobody wants to undermine the stone, to get rid of the tradition: so our neighbours are like the Arabs at Petra, who have been shooting with sling, bow, and matchlock, for a thousand years, at the urn, where they are sure Pharaoh's treasure is, - in its niche in the rock temple. For a thousand years, they have failed to bring it down, and are determined that no European shall. And no European would dismantle the temple to disabuse the Arabs; and so the tradition and the urn stand untouched. So may it be for ages to come with Long Meg, and the giant of eight tons' weight that presides over the Keswick circle!

The ascent of Saddleback may begin behind Threlkeld, up a path which the villagers will point out: but an easier way is, to diverge from the main road some way further on, by the road to Hesket, near the village of Scales. The hill-side path is to be taken which leads along Souter Fell, by the side of the stream which descends from Scales tarn. This part is the very home of superstition and romance. This Souter, or Soutra 
Fell, is the mountain on which ghosts appeared in myriads, at intervals during ten years of the last century, - presenting precisely the same appearances to twenty-six chosen witnesses, and to all the inhabitants of all the cottages within view of the mountain; and for a space of two hours and a-half at one timethe spectral show being then closed by darkness. The mountain is full of precipices which defy all marching of bodies of men; and the north and west sides present a sheer perpendicular of 900 feet. On Midsummer eve, 1735, a farm-servant of Mr. Lancaster's, half-a-mile from the mountain, saw the eastern side of the summit covered with troops, which pursued their onward march for an hour. They came, in distinct bodies, from an eminence in the north end, and disappeared in a niche in the summit. When the poor fellow told this tale, he was insulted on all hands; as original observers usually are when they see anything wonderful. Two years after, also on a Midsummer eve, Mr. Lancaster saw some men there, apparently following their horses, as if they had returned from hunting. He thought nothing of this ; but he happened to look up again ten minutes after, and saw the figures now mounted, and followed by an interminable array of troops, five abreast, marching from the eminence and over the cleft, as before. All the family saw this, and the manœuvres of the force, as each company was kept in order by a mounted officer who galloped this way and that. As the shades of twilight came on, the discipline appeared to relax, and the troops intermingled, and rode at unequal paces, till all was lost in darkness. Now, of course, all the 
Lancasters were insulted, as their servant had been: but their justification was not long delayed. On the Midsummer eve of the fearful 1745, twenty-six persons, expressly summoned by the family, saw all that had been seen before, and more. Carriages were now interspersed with the troops ; and every body knew that no carriages ever had been, or could be, on the summit of Souter Fell. The multitude was beyond imagination; for the troops filled a space of half-a-mile, and marched quickly till night hid them, - still marching. There was nothing vaporous or indistinct about the appearance of these spectres. So real did they seem that some of the people went up, the next morning, to look for the hoof-marks of the horses; and awful it was to them to find not one foot-print on heather or grass. The witnesses attested the whole story on oath before a magistrate; and fearful were the expectations held by the whole country-side about the coming events of the Scotch rebellion. It now came out that two other persons had seen something of the sort in the interval, viz., in 1743, - but had concealed it to escape the insults to which their neighbours were subjected. Mr. Wren, of Wilton Hall, and his farm-servant, saw, one summer evening, a man and a dog on the mountain, pursuing some horses along a place so steep that a horse could hardly, by any possibility, keep a footing on it. Their speed was prodigious, and their disappearance at the south end of the fell so rapid, that $\mathrm{Mr}$. Wren and the servant went up, the next morning, to find the body of the man who must have been killed. Of man, horse, or dog, they found not a trace : and they came 
down, and held their tongues. When they did speak, they fared not much the better for having twenty-six sworn comrades in their disgrace. As for the explanation, - the Editor of the Lonsdale Magazine declared (Vol. ii. p. 313.) that it was discovered that on that Midsummer eve of 1745 , the rebels were "exercising on the western coast of Scotland, whose movements had been reflected by some transparent vapour, similar to the Fata Morgana." This is not much in the way of explanation: but it is, as far as we know, all that can be had at present. The facts, however, brought out a good many more; as the spectral march of the same kind seen in Leicestershire in 1707: and the tradition of the tramp of armies over Helvellyn, on the eve of the battle of Marston Moor. And now the tourist may proceed, - looking for ghosts, if he pleases, on Souter Fell.

Here, too, lies another wonder, - that tarn (Scales Tarn) which is said to reflect the stars at noonday, a marvel which we by no means undertake to avouch. The tarn is so situated at the foot of a vast precipice, and so buried among crags, that the sun never reaches it, except through a crevice in early morning. This - dark water is one of the attractions which bring strangers to this mountain; though the easy ascent of Skiddaw better suits the greater number. Another attraction here is the deeper solitude of the recesses of old Blencathra, - as Saddleback should still be called. Another is the view of Derwent Water from the summit. Southey says, "Derwent Water, as seen from the top of Saddleback, is one of the finest moun- 
tain scenes in the country." That summit is called Linthwaite Fell; and there the guide will point out, better than we can do, the various objects, - seas, islands, castles in their woods, and cities of the plain; mountains, far and near; shores, like the boundaries of an estate, and lakes like its fish-ponds. People who made the ascent sixty years since have left a terrifying account of its dangers, such as now excites a smile among energetic tourists. One gentleman was so "astonished," near the outlet, "with the different appearance of objects in the valley beneath," that he chose to stay behind. Another of the four presently "wished to lose blood and return:" but he was coaxed onwards to the tarn, where, however, he could see no stars, though it was noonday. Mr. Green, with his companion $\mathrm{Mr}$. Otley, was among the earlier adventurers who stood on the highest ridge. He was so accurate an observer that his descriptions of unfrequented and unalterable places will never be antiquated. "From Linthwaite Pike," he says, "on soft green turf, we descended steeply, first southward, and then in an easterly direction to the Tarn; a beautiful circular piece of transparent water, with a well-defined shore. Here we found ourselves engulphed in a basin of steeps, having Tarn Crag on the north, the rocks falling from Sharp Edge on the east, and on the west, the soft turf on which we had made our downward progress. These ' side-grounds, in pleasant grassy banks, verge to the stream issuing from the lake, whence there is a charming opening to the town of Penrith; and Cross Fell seen in extreme distance. Wishing to vary our line in 
returning to the place we had left, we crossed the stream, and commenced a steep ascent at the foot of Sharp Edge. We had not gone far before we were aware that our journey would be attended with perils : the passage gradually grew narrower, and the declivity on each hand awfully precipitous. From walking erect, we were reduced to the necessity either of bestriding the ridge, or of moving on one of its sides, with our hands lying over the top, as a security against tumbling into the tarn on the left, or into a frightful gully on the right, - both of immense depth. Sometimes we thought it prudent to return; but that seemed unmanly, and we proceeded; thinking with Shakspere that 'dangers retreat when boldly they're confronted.' Mr. Otley was the leader, who, on gaining steady footing, looked back on the writer, whom he perceived viewing at leisure from his saddle the remainder of his upward course." On better ground they had a retrospect on Sharp Edge, - which is the narrowest ridge on Saddleback, or any other north-of-England mountain. In places, its top is composed of loose stones and earth; and, the stepping on the sides being as faithless as the top, the Sharp Edge expedition has less of safety in it than singularity.

And now, - those who, after this, like to go there, know what they have to expect.

The other mountain-lake, lying north-east of this, and called Bowscale Tarn, is also reputed to reflect the stars at noonday, but under so many conditions, that it will be a wonder if any body ever has the luck to see them. It is in this tarn that, in the belief of the 
country people, there are two fish which cannot die ; - the same fish that used to wait on the pleasure of the good Lord Clifford when, in his shepherd days, he learned mathematics from the stars upon the mountain. The traveller can return either by the way he came; or by Knott Crag, down upon Threlkeld; or by following the course of the Glenderaterra, along the skirts of Saddleback and Skiddaw, - coming out upon the Keswick road about a mile from Threlkeld. This last mode of descent is considered by far the most interesting.

Whenever he passes that bit of road to Keswick, he will be more and more struck with the advantages of the situation of the mansion on Greta Bank, with its airy position, its walks through the woods, with the Greta dashing below; and afar, the uninterrupted view of the whole of Derwentwater basin and surrounding mountains. The tenth commandment is, we imagine, oftener broken there than in most places. 


\section{PART III.}

\section{CIRCUIT OF THE LAKE DISTRICT.}

\section{FIRST TOUR.}

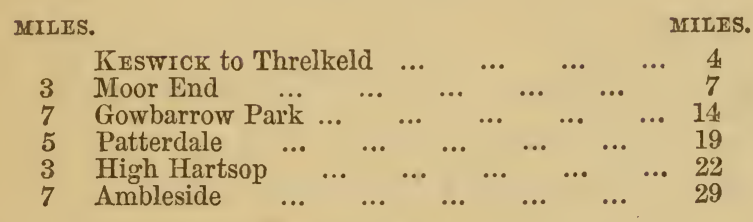

There is a circuit by which the chief objects of the Lake District can be seen in four days, even by ladies and elderly persons. We will describe this route, interpolating some directions for stout pedestrians who can undertake more than the majority of tourists.

The starting-point of this tour may be either Keswick or Ambleside, according as the traveller enters the district from the north or the south. Supposing it to be Keswick, the first day's journey is by Matterdale to Ullswater, and by the Kirkstone Pass to Ambleside. 
The distance from Keswick to Patterdale is nineteen miles; and from Patterdale to Ambleside ten more; so that the journey should begin in good time, if the scenery is to be duly enjoyed. The first part of the road, as far as Threlkeld, has been abundantly described. It then becomes wild and bleak, while commanding noble distant views of the Keswick mountains, and of the saddle-shaped aspect of old Blencathra. Mell Fell, the ugliest of hills, - like a tumulus planted all over with larch, grows larger as the traveller proceeds, till he finds he is to make a sharp turn to the right, and pass directly under it. Judging from our own experience, we should say that this part of the journey is always broiling hot or bitterly cold. A bleak high-lying tract it certainly is, where the old monks no doubt suffered much and often in their expeditions. Their paternosters said among the perils of Ullswater, and their Ave Marys here are supposed to have given the names of Patterdale and Matterdale, which become more interesting as soon as their origin is known. From Matterdale, the road drops down upon Gowbarrow Park, already described at p. 38. It is a usual practice to send on the carriage to the Patterdale Inn, (weather permitting) where the driver will order dinner to be ready in two hours or so: and then the traveller will explore the park, and see Ara Force, and walk the remaining four miles, enjoying as he goes, the very finest views of Ullswater. An ordinary party of travellers will be content with the road to Ambleside, to close the labours of the day. But young men will choose, if there be daylight left, 


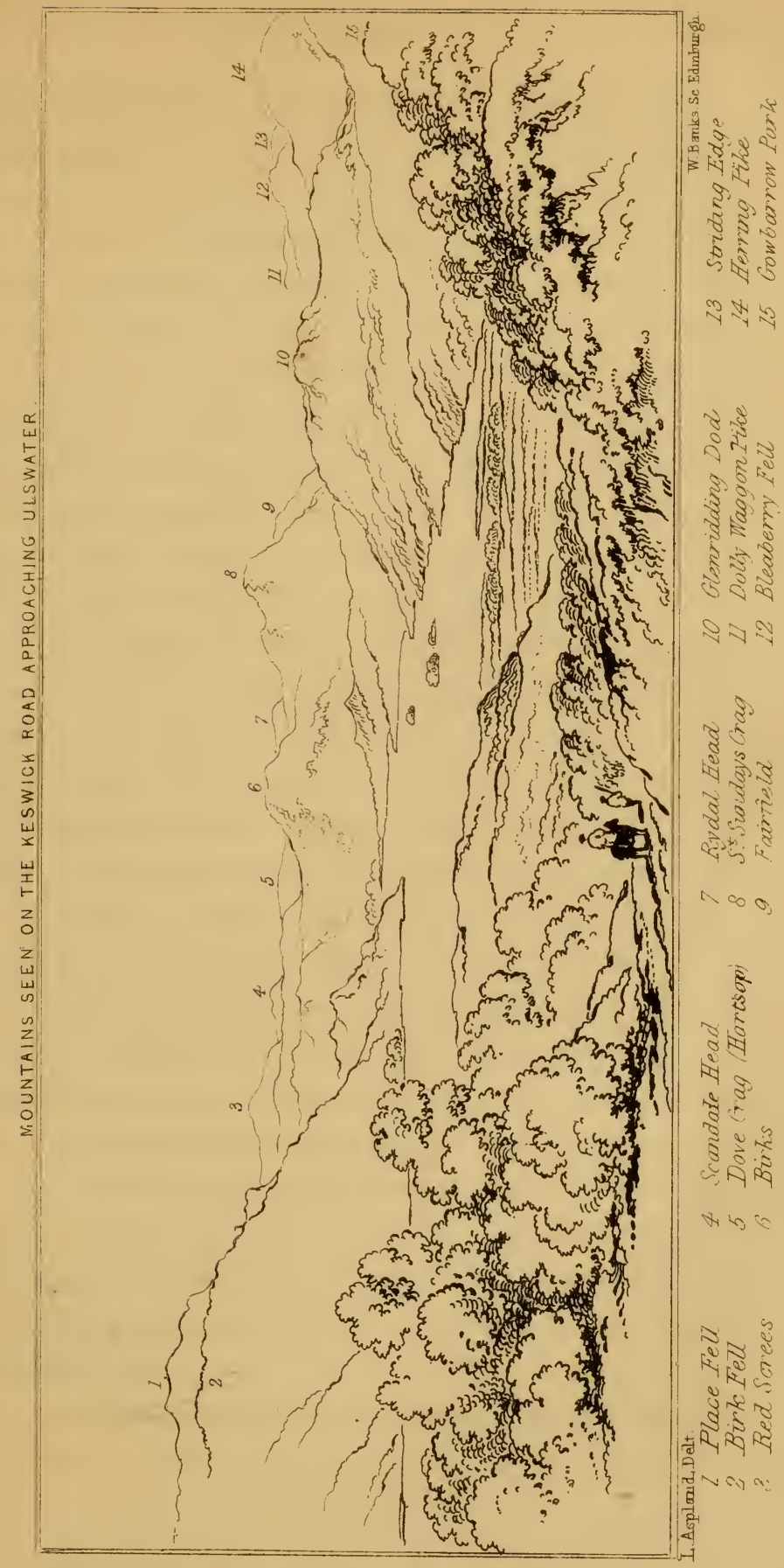



to diverge to the left at Hartsop, to see Hays Water. The track passes among the farms, and beside the beck, between the mountains, and up till the source is reached, - the secluded tarn called Hays Water. This little lake is a mile and a-half from the main road, and the ascent is rather steep. It is the delight of the angler, because it is also the delight of the trout. It is overhung by High Street; so that perhaps the Roman eagles, as well as the native birds of the rocks, have cast their shadows upon its surface. Not far off lies Angle Tarn, on the southern end of Place Fell. Both these tarns send their brooks down, to swell the stream from Brothers' Water, which is itself supplied from the busy, noisy beck that descends the Kirkstone Pass; and the whole, united with a tributary from Deepdale, form the clear brown stream which winds through Patterdale, and empties itself into Ullswater. Brothers' Water derives its name from the accident which is said to have happened twice, - of brothers being lost in it, in the attempt of one to save the other. On one of the two occasions, the accident happened through the breaking of the ice, when the brothers were making a venturesome short cut across it to church. - No persuasion of ours can be necessary to induce any traveller to visit Deepdale, if he has time. Its aspect from the road is most tempting; - only, it cannot, like the walk to Hays Water, be accomplished, in the longest summer day, in addition to the route given for the day.

An account of Ambleside will be found at p.p. 41, 55 . 


\section{SECOND TOUR.}

AMBLESTDE TO STRANDS AND WAST WATER.

MILES.

MILES.

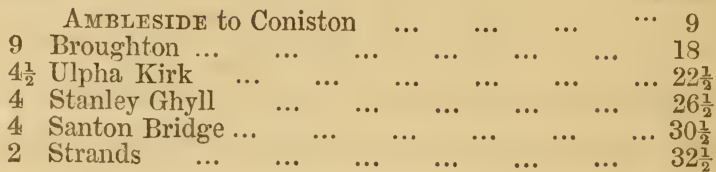

MILIS.

MILES.

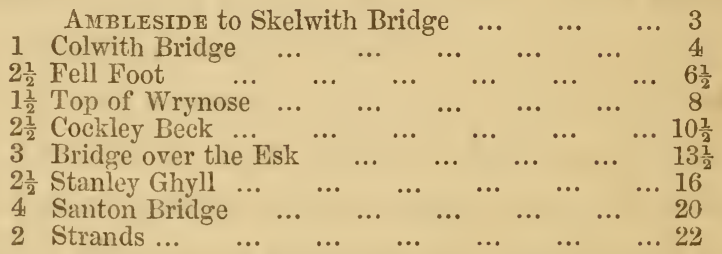

There are two ways, meeting at Stanley Ghyll, (the grand waterfall of the district,) - which are about equally beautiful, though entirely unlike; but the shorter one, by Cockley Beck, is fit only for good walkers, in fair weather. There is no reason why ladies should not achieve it, by taking ponies, or a car, which they will leave in the steeper parts. We will suppose, in order to describe both, that the party divides, - the young men going sixteen miles on foot, by the mountains to Stanley Ghyll, and meeting there the carriage party, who have made a circuit of about ten miles longer, and will take up the pedestrians for the remaining six miles to Strands.

The drive to Coniston has been already described. 
The road now to be followed, passes through Coniston and Torver, and then diverges from the lake, overlooking a region in which the hills sink into heathery undulations, which again subside into a wide alluvion, which stretches to the estuary. When it is high water, the scene is fine: but the vast reaches of sand at low water are dreary. The coast railway is seen crossing the estuary, - its cobweb tracery showing well against the sand or the water. Near at hand Broughton Tower rises from the woods above the little town: but there is nothing else to detain the eye. Tourists who desire to ascend Blackcombe, should do it from hence, - the summit being only six miles from Broughton; and guides are here to be procured. Wordsworth says of this mountain that "its base covers a much greater extent of ground than any other mountain in those parts ; and, from its situation, the summit commands a more extensive view than any other point in Britain." One would think that this testimony, and Col. Mudge's information that, when residing on Blackcombe for surveying purposes, he more than once saw Ireland before sunrise, would bring strangers to try their luck in seeing Scotland, Staffordshire, and Ireland, from the same point: but the mountain lies out of the ordinary track of tourists, and very few visit it.

The next portion of the drive is charming; - up the valley of the Duddon. The series of sonnets that Wordsworth has given us may have led strangers to expect too much: but to an unprepossessed eye the valley must appear lovely. Leaving the Bootle road 
and the bridge to the left, the road ascends so steeply that the travellers will get out and walk; and many a time will they turn to the sea-view, and the wooded slopes on the way to Bootle, and the rocks, dressed with wild flowers, that enclose the road. Then comes a common covered with fern, in which the greenest of paths form a net-work: and far below dashes the brown river, between rocky banks; and Duddon Grove, with its conservatories and beautiful grounds and green elearings, is seen in the hollow of the vale. Four miles from Broughton, the bridge at Ulpha Kirk spans the river, and discloses a beautiful view, up and down, One thing which the traveller is always expected to remark is the strange holes (called pots) worn by the waters in the rocks, and the rounding of the edges of the boulders and shelves in the channel. Ulpha Kirk is a mere hamlet; but there is a little inn at which the horses can rest if the party are disposed for a walk to the scene of Robert Walker's life and labours. Ulpha Kirk itself is one of the priniitive places where the old manners of the district may yet be traced more clearly than in most road-side settlements. The people still think it no sin to do their farm work on Sundays, when the weather, - so precarious here, - is favourable; and the familiar style of "the priest" in these parts makes the transition from work to worship very natural. Some time since there was a blind "priest" settled there. One Sunday morning, the bell rang before the people were all ready; and especially the stoutest farmer in the neighbourhood, who, detained by some cow, pig, or sheep, entered the church last of all, "thunnerin' down 
the aisle." "Wha's comin' now?" asked the blind priest; and, being informed by the clerk that it was John T_- he inquired further, "a-foot or a-horseback?" Odd sprinklings of learning are found in these by-places, as in Scotland. Some students staying at this same little inn, and wanting to settle their account, wrote a note in Latin to the landlord, asking for the bill, and sent it by the girl who waited. Mr. Gunson, the landlord, (from whom the present landlord is descended) immediately sent in the bill in Greek. It was too much for the students, who where obliged to ask to have it in English. There was a "heigh larned" woman, not far from hence, who married a farmer on the moor. When every body was lamenting the hard times, she declared that, for her part, she should be contented if she could obtain food and raiment; whereupon her husband rebuked her presumption. "Thoo fule," said he: "thoo dusn't think thoo'st to hev mare than other folk. I'se content wi' meeat and claes."

Newfield Church, in Seathwaite, is the place where Robert Walker, called "the Wonderful," exercised his office for sixty years. The grey farmsteads stand under their sycamores, dispersed in the vale, and up the slope which meets the Walna Scar track from Coniston. Rocky and wooded knolls diversify the dale; and the full beck runs down to join the Duddon, for which it is often mistaken: but the Duddon is unseen here, so deep lies its channel among the rocks. The church is little loftier or larger than the houses near. But for the bell, the traveller would hardly 
have noticed it for a church on approaching: but when he has reached it, there is the porch, and the little graveyard, with a few tombs, and the spreading yew, encircled by the seat of stones and turf, where the early comers sit and rest till the bell calls them in. A little dial, on a whitened post in the middle of the enclosure, tells the time to the neighbours who have no clocks. Just outside the wall is a white cottage, so humble that the stranger thinks it cannot be the parsonage: yet the climbing roses and glittering evergreens, and clear lattices, and pure uncracked walls, look as if it might be. He walks slowly past the porch, and sees some one who tells him that it is indeed Robert Walker's dwelling, and courteously invites him in to see the scene of those life-long charities. Here it was that the distant parishioners were fed on Sundays with broth, for which the whole week's supply of meat was freely bestowed. Hither it was that in winter he sent the benumbed children, in companies, from the school in the church, to warm themselves at the single household fire, while he sat by the altar all the school hours, keeping warmth in him by the exercise of the spinning wheel. But the story is too well known, as it stands in Wordsworth's works, to need further celebration here: too well known, we should think, not to induce tourists to walk two miles from Ulpha Kirk and back again, to visit the homes, in life and in death, of Robert Walker. There are changes even here. There is a school-house, warmer in winter than the church: and there is a decline in the number of attendants at church. The Wesleyan 
chapel at Ulpha has drawn away some; and the taste for Sunday diversion, which has found its way over the hills from Coniston, estranges more; and the descendant and successor of the good pastor says that "the old stocks are gone, and the new families are different." 'Thus is the large world's experience reflected in this little vale!

The finest part of the Duddon scenery is just here; and it is a charming walk by the stepping-stones, celebrated by Wordsworth, and up and over the moor, to descend upon Eskdale. The travelling party sees nearly the same view, as far as the mountain is concerned, by crossing at Ulpha Kirk, and getting upon the moor that way. As soon as the enclosures are past, up springs the lark, and freely run the rills, and keen is the air; and ghostlike are the mountains that appear by degrees above the high foreground of the moor. It is a rare pleasure in the lake district to meet with the lark. It is only on a very wide expanse of moorland that it can happen; for in the valleys the birds of prey allow no songsters. The eagles are gone (or nearly), and few ravens are left among the crags: but there are hawks domineering in every vale; so that those who would hear the lark must go out to such places as Birker Moor. - The mountain group in front is that which has been remarked upon before as the centre of the region; - the lofty nucleus whence the vales diverge (as Wordsworth observed after Green) "like the spokes of a wheel." Scawfell is the highest; and the whole line, from that peak to Hardknot, is very fine in all lights. The dark basin 
formed in the midst of the group will be observed. There Wast Water lies.

On the right, a rude new road at length appears, tending towards a wooded ravine. That ravine is Stanley Ghyll, and at its head is the waterfall. The key may be had at the farmhouse of Dalegarth; and there perhaps, or in the glen, the party from Fellfoot may be found to have arrived first.

The Stanley Gliyll fall has much the character of Ara Force; and the immediate surroundings may perhaps be rivalled by other waterfalls in the district. But the glen itself is indisputably the finest in the region; and it is scarcely possible to say too much of the view from the Moss-house on the steep, which should certainly be the first point of view. From hence the eye commands the whole ravine, whose sides are feathered with wood from base to ridge. The fall is between two crags, - the one bare, the other crowned with pines; and if there is a slant of sunlight between them, it gives the last finish of beauty to the chasm. The most modern element in the scene, the young larches, cannot offend the eye, - so well as their vivid green is intermingled with the well-grown beech, oak, birch, and hollies, of a soberer hue. There is a bridge below, descried from the moss-house, which will tempt the stranger to find his way down; and there he will meet with two more, by means of which he will reach the fall. Here, among a wilderness of ferns and wild flowers, he may sit in the cool, damp abyss, watching the fall of waters into their clear rock-basin, till his ear is satisfied with their dash and flow, and his eye with 
the everlasting quiver of the ash sprays, and swaying of the young birches which hang over from the ledges of the precipice. A path then leads him under the rocks, now on this side of the stream, and now on that, till he emerges from the ravine, and winds his way through the hazel copse to the gate.

It may be thought that our travellers have not leisure for much of this meditating in the glen: and it is true that by this time, the sun is sloping westwards; but there are only six miles to be travelled; and there are no more rough mountain tracks to-day, but a good road, - (wonderfully red) across Eskdale, and all the way to Strands.

After crossing the Esk, and passing the little inn at Bout, the road runs above the river, till, at the King of Prussia Inn, it turns up out of Eskdale, and crosses into Miterdale. Before Eskdale is lost sight of, the opening of the valley to the sea affords a fine view, with the little town of Ravenglass seated in the bay where the Irt, the Mite, and the Esk flow into the sea. Then comes a long ascent, and more views of the levels towards the coast, - rich with woods and fields, bounded by sands and sea. Then there is a descent, to cross the Mite; and another ascent; and a descent again to pretty Santon Bridge, on the winding Irt. Instead of passing the bridge, however, the road to the right must be taken, which leads, in two miles, to Strands. There is again a long ascent: but even the tired traveller will not complain of it, when the circle of mountains round Wast Water opens before him. The lake is not visible; but there is no mistaking where it lies. To 
the right, and close at hand, the Screes present their remarkable sweep of débris, and crests streaked with red, grey, and vivid green, and here and there cloven for the passage of cataracts from the brow, which tumble down through the gloom of woods. Hawlghyll is the largest of these ravines. Next, the Scawfell peaks rise above the rest; and Great End just peeps over the shoulder of Lingmell. The cleft between Lingmell and Great Gable is Sty Head Pass ; and to the left, from Great Gable, are Yewbarrow and Middlefell. The broken foreground on the common whence this view is seen adds greatly to its beauty. Descending upon Wastdale, the Irt is crossed; and then the road meets others on the green. The one to the right leads to the lake. Sweeping round to the left, and passing the church, - so small and domestic-looking as to appear like a house, - the road reaches the two little inns. They are humble but clean; and horses can be had, and boats for the lake.

Now we must see how the party by Fellfoot has fared.

Their route has been described, as far as Skelwith Bridge; - viz: the road by Clappersgate, and the Brathay valley, in which, however, they must keep the right-hand road. Passing Skelwith Bridge, they had better, if on foot, go through the gap in the wall mentioned in p. 47, and follow the path in the wood which will lead them out into the road at the top of the hill. After about a mile from thence, they must take the road to the right, which turns sharp down the very steep hill to Colwith Bridge. Colwith Force, a 
little further on, will make itself heard and seen. It tumbles from a height of seventy feet, and the adjuncts are beautiful. One mile further along the winding road or lane, Langdale Tarn comes into view, with Wetherlam swelling up grandly to the south of it. About a mile further on, there is a gate from which the road parts; - the straight forward one leading on to Blea Tarn and Langdale; and the left hand one, which our travellers must follow, leading to Fellfoot, and the old road from Kendal to Whitehaven, which was the only route before carriers' carts found their way into the region. Fellfoot was the house of entertainment whence the pack-horse cavalcade began the ascent, or where they stopped to congratulate themselves on having accomplished the descent. The ascent of Wrynose from this point is long and rather steep: but the views behind become grander with every step. The travellers are now in Westmorland; but at the three shire stones at the top, where three counties meet, they will step into Lancashire, in order to leave it for Cumberland at Cockley Beck bridge, within three miles further on. We are glad to hear that a spirited citizen of Ambleside, to whom his neighbours are under great obligations, is erecting a stone pillar at the spot where the shire stones are, that the junction of counties may not be overlooked (as it easily may be now) by the unobservant traveller. Young tourists, who happen to have long limbs, may enjoy the privilege of being in three counties at once, by setting their feet on two of the three stones, and resting their hands on the third. The stream which is now on the right, divides Lancashire 
from Cumberland; and Westmorland is left behind.

We know nothing wilder in the district than the next two miles. These are the desolate hills in which the Duddon and the Esk take their rise ; and Cockley Beck is the spot where the Duddon must be left, to cross over to the Esk. There is a farmhouse near the bridge, where horses can be refreshed, when a car comes this way, while travellers sit down by the stream to dinner. A melancholy and harassed traveller once came this way, whose adventure is still talked over in Eskdale and Borrowdale. A party of tourists, among whom were two sisters, were on the heights, intending to cross Esk Hause into Borrowdale, and to spend the night at Seathwaite, - the first settlement there. Now there is, as we have seen, another Seathwaite on the Duddon; and mistakes frequently arise between them. On Esk Hause, one of the ladies lost sight of her party behind some of the rocks scattered among the tarns there, and took a turn to the right instead of the left. A shepherd of whom she mquired her way to Seathwaite, pointed down to the Duddon valley; and that way she went till she found herself at Cockley Beck, when the old shepherd farmer who lived there was getting his supper in the dusk of the autumn evening. He used his best courtesy to induce her to stay till daylight: but she was bent on going at once, - so great would be her sister's terror. As she would not be persuaded, the old man went with her, putting his crust into his pocket. It was dark, and the lady was weary; and she was not aware what she was undertaking. After a long struggle, she fainted. The old 
man was afraid to leave her, lest he should not find her again : but he succeeded in reaching the water without losing sight of her white dress. He dipped his crust, and brought water in his hat to bathe her face. She revived, ate the crust, and strove onwards, - persevering on her weary way till between one and two in the morning, when she met her sister and a party coming from Seathwaite in Borrowdale, with a dozen lanterns, to search for her. She gave her guide "a one-pound note;" (it was so long ago as that) and afterwards, sent him two more. The whole family connexion of that lady will remember for ever that there is a Seathwaite on each side Esk Hause.

From Cockley Beck, the road climbs the side of Hardknot, and from the highest point commands a view of the sea. The descent into Eskdale is charming, - the ravine to the left, in which the infant river flows down, being beautifully wooded, and the whole valley, with its few hamlets and many sheep, lying open, as far as the sea. In three miles from Cockley Beck, the bridge over the Esk is passed; and Stanley Ghyll is less than three miles further. Scawfell, and all that group of summits are in view to the right, during the descent: and to the left, Birker Force is seen dashing over the rocks. Bout comes next, and then Dalegarth and Stanley Ghyll, where our travellers will join their party, after a walk of sixteen miles from Ambleside. 


\section{THIRD TOUR.}

FROM STRANDS AND WAST WATER TO SCALE HILL INN.

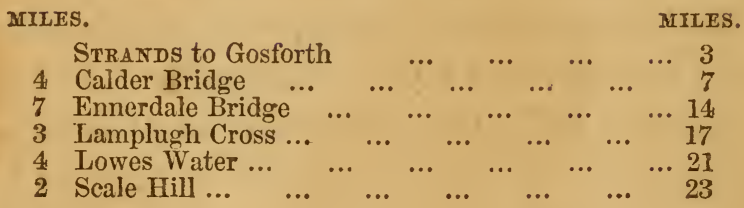

The objection to seeing Wast Water early in the morning, is that Scawfell may too probably be covered with clouds. He does not take off his night cap so soon as the pleasure-seekers. On this account, we have preferred, when weather was favourable, the Fellfoot way to Strands, as leaving time for an evening drive to Wastdale Head, - five miles and back again. The travellers by Broughton must no doubt wait till the morning. Taking a cup of tea and a crust, and ordering breakfast for two hours hence, the party may start early for the far-famed Wast Water, - the most solemn and imposing of all the lakes. For some way, the road is a pretty lane, with frequent gates, till the beautiful abode of Crook End, the seat of Stanfield Rawson, Esq., is passed. Hawlghyll and the other fissures are probably breathing forth their vapours, which keep ascending all the way. There are the Screes, with the grey and still lake, - too deep to be ever frozen, lying at the base of their prodigious sweep. 


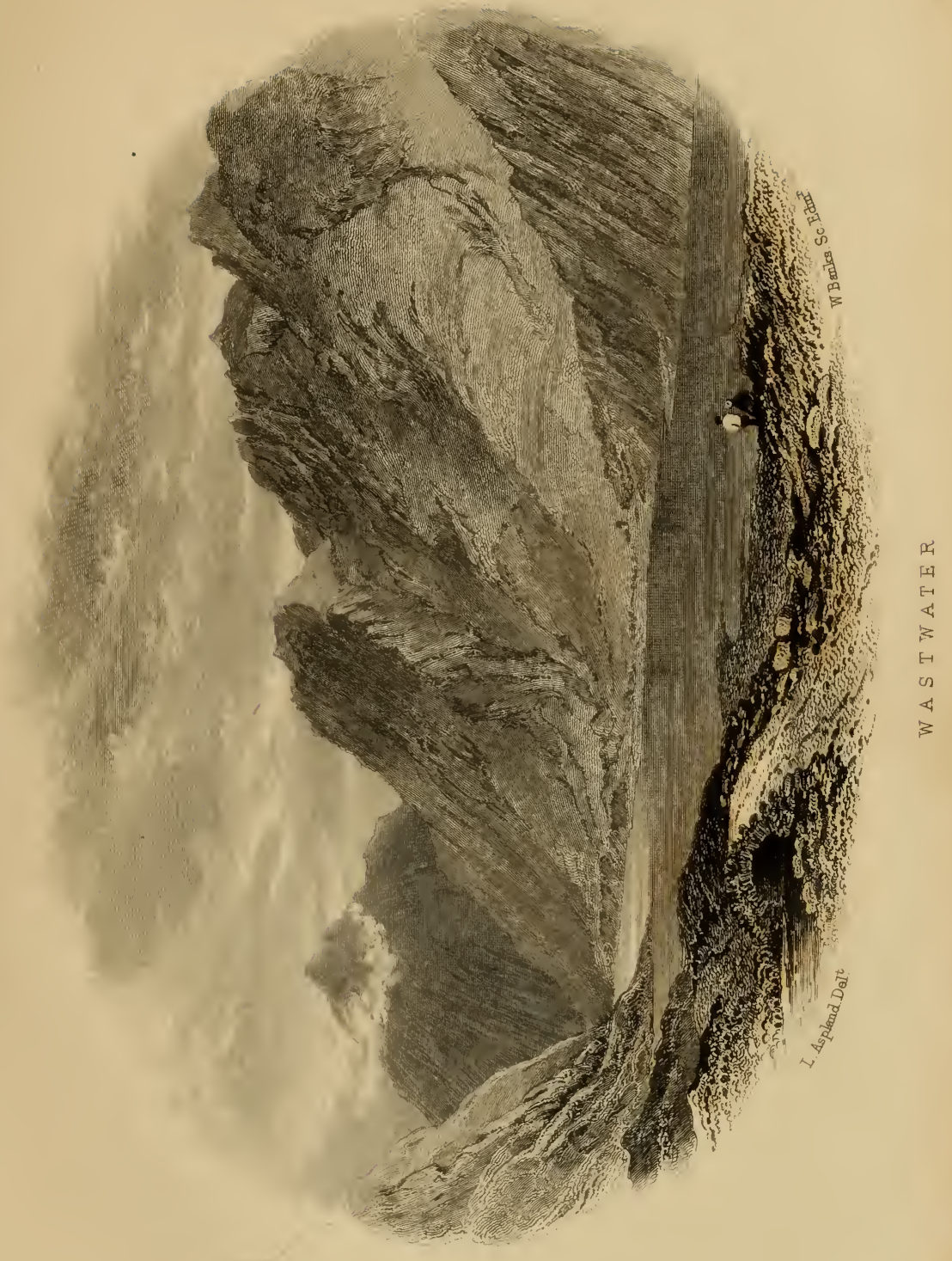


The lake is three and a-half miles long, and has the Screes for its south-eastern shore. The line of this singular range is almost unbroken. The crags are hidden, about a-third of the way down, by the slope of many-coloured débris which slants right into the lake. The summer thunderstorm and the winter tempest sometimes shiver the loosely-compacted crags above; and then, when a mass comes thundering down, and splashes into the lake, the whole range feels the shock, and slides of stones rush into the water, and clouds of dust rise into the air.

We gave in approaching Strands, (p. 78.) the names of the mountains as they are now seen. The road winds pleasantly round bays and over promontories, and the pyramidal Yewbarrow, Great Gable, which closes in the dale, and Lingmell and the Scawfell Pikes to the right, all explain themselves. Several brooks and rills are passed, flowing down from the valleys; and the stranger exclaims that he should like to spend a whole summer here, to explore all the ways among the mountains. Several gentlemen have spent weeks together at Ritson's farm-house, at the dale head, where there are clean beds, and farm-house fare in plenty and perfection. The opening out of the dale head, when the valley has appeared to close in round the lake, is as wonderful a spectacle to strangers as any thing they see. The dale is one of those perfect levels, shut in by lake and mountains, which give a different impression from any other kind of scenery in the world. The passes themselves are so high as to leave no appearance of outlet, except by the 
lake; and of these passes there are but two, - the Sty Head and Mosedale paths. The green and perfect level, to which the mountains come down with a sheer sweep, is partly divided off into fields ; and a few farmhouses are set down among the fields, on the bends of the gushing and gurgling stream. There is a chapel, - the humblest of chapels, - with eight pews, and three windows in three sides, and a skylight over the pulpit. There is now a school : - a chapel and a school and no public house! The schoolmaster is entertained on "whittlegate" terms : that is, he boards at the farm-houses in turn. An old man told us that the plan answers. "He gets them on very well," said he; "and particularly in the spelling. He thinks that if they can spell, they can do all the rest." Such are the original conclusions arrived at in Wastdale Head. It struck us that the children were dirtier than even in other vales, though the houses are so clean that you might eat your dinner off the board or the floor. But the state of children's skin and hair is owing to superstition, in all these dales; and the schoolmaster is the one who should cure the evil. A young lady who kindly undertook to wash and dress the infant of a sick woman, but who was not experienced in the process, exclaimed at the end " $\mathrm{O}$ dear! I forgot it's

- hands and arms. I must wash them." The mother expressed great horror, and said that "if the child's arms were washed before it was six months old, it would be a thief ;" and, added she, pathetically, "I would not like that." The hair and nails must not be cut for a much longer time, for fear of a like result. 
The Yorkshire people put the alternative of dirty and clean rather strongly in their proverb, "Better hev a bairn wi a mucky feace than wash its noase off:" but the Cumberland folk view the matter more in a moral way, and refuse to have their children baptised into thievery.

Kirkfell, which stands backward, between Yewbarrow and Great Gable, was very tempting to a tourist who explored this neighbourhood some years ago ; and he set out to get to Buttermere by Blacksail and Scarf Gap. After hours of walking, he struck into the deep ravine between Kirkfell and Great Gable; and when he arrived within sight of a lake at night, he was confounded to find it still Wast Water. He had walked completely round the mountain, instead of getting on. We observed to a comrade that this could not have happened if the tourist had carried a pocket-compass. "And not having a compass," said our friend, "he fetched one." Wastdale Head is the place whence the ascent of Scawfell should be made : but we must defer that; as it would occupy the eneryies of a whole day. The party will now return the way they came; for there is no road, of course, under the Screes, though the shepherds venture along a perilous thread of a path in the loose débris.

After breakfast, the travellers will address themselves . to the very different spectacle of Calder Abbey and its environs.

After climbing the long hill from Strands, an eager look-out will be kept for the Isle of Man: but the most probable point for seeing it is at the top of the 
hill between Gosforth (the reddest of villages) and Calder Bridge. Far off at sea rises the outline of its mountains ; and when the wind is east, we have repeatedly seen the shadows filling the hollows of its hills. From this eminence, the road descends through a avenue of beech, ash, and other trees, to Calder Bridge.

Here the travellers will leave the carriage, which will meet them within an hour at Captain Irwin's gate, on their quitting the Abbey. They must now step into the inn garden at the bridge, and see how beautifully the brown waters swirl away under the red bridge and its ivied banks, while the waving ferns incessantly checker the sunshine. It is a mile to the Abbey, through the churchyard, and along the bank of the Calder, where again the most beautiful tricks of light are seen, with brown water and its white foam, red precipitous banks, and the greenest vegetation, with a wood crowning all. The scene is thoroughly monastic. There is no sound at noonday besides the gushing water, but the woodman's axe and the shock of a falling tree, or the whirr of the magpie, or the pipe of the thrush : but at night the rooks on their return to roost fill the air with their din. The ruins are presently seen, springing sheer from the greenest turf. Relics from the abbey are now placed beside the way; and the modern house appears at hand. The ruins should be approached from the front, so that the lofty pointed arches may best disclose the long perspective behind of grassy lawn and sombre woods. The Abbey is built of red sandstone of the neighbourhood, now sobered down by time (it was founded in A.D. 1134.) into the richest 
and softest tint that the eye could desire. But little is known of it beyond its date and the name of its founder, Ranulph, son of the first Ranulph de Meschines, a Norman noble. The church was small, as the scanty remains show; and the monastery, which now looks like a continuation of the same building, could not have contained a numerous company. From the fragments of effigies preserved, it appears that some eminent persons were buried here; but who these knights and nobles were, there is no record that can tell, - carefully as these memorials were wrought to secure the immortality of this world. The eye is first fixed by the remains of the tower, from whose roofless summit dangles the tufted ivy, and whose base is embossed by the small lilac blossoms of the antirrhirom; but at last the great charm is found in the aisle of clustered pillars. Almost the whole aisle is standing, still connected by the cornice and wall which supported the roof. The honeysuckle and ivy climb till they fall over on the other side. There is a sombre corner where the great ash grows over towards the tower, making a sort of tent in the recess. There are niches and damp cells in the conventual range. It is a small ruin, but thoroughly beautiful: and when the stranger looks and listens, as he stands in the green level between woods, he will feel how well the old monks knew how to choose their dwelling-places, and what it must have been to the earnest and pious among these Cistercians to pace their river bank, and to attune their thoughts to the unceasing music of the Calder flowing by. In the broad noon it is a fine thing to see the 
shadows flung, short and sharp, on the sward, and to catch the burnish of the ivy, and woo the shade of the avenue : and in the evening, it is charming to see how the last glow in the west brings out the projections and recesses of the ruins, and how the golden moon hangs over the eastern mass of tree tops, ready to take her turn in disclosing the beauties of the monastic retreat.

The Abbey is carefully preserved, and liberally laid open to strangers by Capt. Irwin. It is no fault of his that his house, a plain substantial modern dwelling, stands too near the ruins. He did not build it; so there is nothing personal in the natural wish of strangers that it stood somewhere else.

At the gate the carriage is waiting, and it takes the cross road, almost opposite the gate, up to Cold Fell. The drive over that fell is commonly called dreary; and it is so in bad weather : but it has its charms. The sea-view is fine, - all flecked with cloud shadows as with islands : and the wide down sprin'sled with sheep, that look as ragged as terriers, after tearing their fleeces with the furze and brambles with which the swelling slopes are embossed. In a hollow, at rare intervals, stands a farm-house, under the ordinary sycamore canopy; and far away, between the slopes of the down below, the soil is cut up into fields, with woods hanging above; and at the mouth of the vale, between it and the coast, stands Egremont, a little town of 1,500 inhabitants or so, and which certainly looks very pretty from the uplands; - and cheerful too, in spite of its Roman name,-(the Mount of Sorrow.) It is distinguished by Roman traditions. It was at the 
gateway of Egremont Castle that the horn was hung, in crusading days, which was twice blown by the gallant Sir Eustace de Lacy. As the Cumberlanders tell, Sir Eustace and his brother Hubert rode forth together to the Holy Wars; and Sir Eustace blew the horn, saying to his brother, "If I fall in Palestine, do thou return and blow this horn, and take possession; that Egremont may not be without a Lacy for its Lord." In Palestine, ambition of this lordship so took possession of Hubert, that he hired ruffians to drown his brother in the Jordan: and the ruffians assured him that the deed was done. He returned home, and stole into the castle by night, — not daring to sound the horn. But he soon plucked up spirit, and drowned his remorse in revels. In the midst of a banquet, one day, the horn was heard, sounding such a blast that the echoes came back from the fells, after startling the red deer from his covert, and the wild boar from his drinking at the tarn. Hubert knew that none but Eustace could or would so sound the horn : and he fled by a postern while his brother Eustace entered by the gate. Long after, the wretched Hubert came to ask forgiveness from his brother; and having obtained it, retired to a convent, where he practised penance until he died. The ruins of this castle stand on an eminence to the west of the town.

Before descending to Ennerdale Bridge, the outline of the Scotch mountains may be sometimes seen. Few travellers see more of this lake than in passing; for, while exceedingly wild, it has not the solemnity of Wast Water; and there is a want of wood, to give it 
grace and beauty. The enclosure of the waters by bare mountains is, however, very fine. The neighbourhood is full of stories, of escapes and strange adventures of such pedestrian tourists as have explored the mountains : but carriage travellers look down from the road, and pass on.

We have mentioned the young man who spent the whole of a previous day in walking round Kirk Fell. Worse happened, in October, 1852, to two gentlemen who went, with a pony, but without a guide, from Buttermere to Wastdale Head, by Scarf Gap and Blacksail. In Ennerdale valley, wind and rain met them. They struggled part of the way along Blacksail, when they became bewildered, and soon so exhausted that they had a narrow escape with their lives. But for a brandy flask, which one of them carried, they could not have survived. The pony seems to have sunk as rapidly as the men. These gentlemen have publicly suggested the erection of some conspicuous landmarks, to show the track; and they have uttered their warning, in corroboration of so many others, against crossing mountains without a guide. One of their chief difficulties was the paths being turned into watercourses, and thereby disguised. It was on the same track that the three Kendal young ladies, mentioned by Mr. Green in his "Guide" (two of whom are still living) lost their way, from dismissing their guide too soon, and actually staid all night on the mountain, where, if it had not been fine summer weather, they would have perished. They took a guide over Scarf Gap, and as far as the junction of the three 
roads from Buttermere, Ennerdale, and Wastdale. The guide left them on the right road, and with full information as to the rest of the way. They took the wrong side of the brook, however, and so got bewildered. It was only four p.m., when the guide left them: but darkness overtook them still wandering. When they came down upon Tyson's house, early in the morning, the family could not believe the story of their descent, so perilous was the way they had come. One of the ladies had, however, lost a pocket-book; and they had seen a dead sheep: and, somebody immediately going up, these incidents were verified; and the adventure of the Kendal ladies remains one of the wonders of the dales.

We had once an adventure in this neighbourhood, the moral of which is, the comfort and security of having a guide. We wanted to cross Blake Fell to Loweswater. The distance to Scale Hill Inn was only six miles; the time summer; and the track well marked on map and mountain. If there ever was a case in which a guide might be thought unnecessary, it was this: but two out of the party were young strangers; and the third would not assume the charge of them. The heat was excessive that day; so we lagged behind the guide, on the ascent, though he carried knapsack and baskets. He was a quiet-looking elderly mountaineer, who appeared to walk very slowly; but his progress was great, compared with ours, from the uniformity and continuity of his pace. In the worst part of the walk, we tried the effect of following close behind him, and putting our feet in his tracks; and we were surprised 
to find with what ease and rapidity we got on. At first we stopped repeatedly, to sit down and drink from the streams that crossed the track, or flowed beside it: and during those halts, we observed that the blackness which had for some time been appearing in the west, now completely shrouded the sea. Next, we remarked that while the wind still blew in our faces, - that is, from the north-east, - the mass of western clouds was evidently climbing the sky. The guide quietly observed that there would be rain by and by. Next, when we were in the middle of the wide fell, and we saw how puzzling the network of swampy paths must be at all times, we pointed out to one another how the light fleeces of cloud below the black mass swept round in a circle, following each other like streams in an eddy. Soon, the dark mass came driving up at such a rate that it was clear we should not finish our walk in good weather. The dense mist was presently upon us. On looking behind, to watch its rate of advance, we saw a few flashes of lightning burst from it. The thunder had for some time been growling afar, almost incessantly. The moment before the explosion of the storm was as like a dream as a waking state can be. We were walking on wild ground, now ascending, now descending; a deep tarn (Floutern Tarn) on our right hand, our feet treading on slippery rushes, or still more slippery grass : the air was dark, as during an eclipse; and heavy mists drove past from behind, just at the level of our heads, and sinking every moment; while before us, and far far below us - down as in a different world - lay Buttermere and the neighbouring vales 
sleeping in the calmest sunshine. The contrast was singular - of that warm picture, with its yellow lights and soft blue shadows, with the turbulence and chill and gloom of the station from which we viewed it. We had but a moment to look at it; for not only did the clouds sink before our eyes, but the wind scudded round to the opposite point of the compass, throwing one after another of us flat as it passed. Within a few minutes, one of us had six falls, from the force of the wind, and the treachery of the ground,-now, in a trice, a medley of small streams. It was impossible to stop the guide, for a moment's breath. In the roar of the blast, and crash of the thunder, and pelt of the hail, one might as well have spoken to the elements: so it was necessary for us all to keep up our pace, that he might not stride away from us entirely. Through stumblings and slidings innumerable, we did this, - the lightning playing about our faces the while, like a will-o'-the-wisp on the face of a bog. The hail and rain had drenched us to the skin in three minutes. The first hailstones reached the skin. They were driven in at every opening of our clothes; they cut our necks behind, and filled our shoes. Our hats and bonnets were immediately soaked through, and every body's hair wringing wet. The thunder seemed to roll on our very skulls. In this weather we went plunging on for four miles, through spungy bogs, turbid streams, whose bridges of stones were hidden in the rushing waters; or by narrow pathways, each one of which was converted by the storm into an impetuous brook. When we had descended into a region where we could hear ourselves speak, we congratulated one another on our prudence 
in having engaged a guide. Without him, how should we have known the path from the brook, or have guessed where we might ford the streams, when the bridges were out of sight? Two horses, we afterwards heard, were killed on the same fell in that storm : and we should never have come down, we were persuaded, if we had been left to wander by ourselves.

Lamplugh Cross is three miles from Ennerdale Bridge; and thence the road begins to descend, and for the most part continues descending for the remaining six miles to Scale Hill Inn. On leaving the common, from which the Solway and Scotch mountains are visible, and turning down through a gate upon Lowes Water, the view of the central mountain group is again very fine. Lowes Water is one of the out-lying lakes, and its lower end is tame accordingly : but it is only a mile long; and the peaks congregate finely about its head. The circuit of Lowes Water, (seven miles) is a charming morning's walk. 'There is a prosperous look about the homesteads there, and a richness about the meadows which smacks of the level country, which, in the shape of the Vale of Lorton, is near at hand. On the road between Lowes Water and the inn at Scale Hill, the great peaks of the central group are all visible, from Grassmoor to Great Gable, and from Scawfell round to Melbreak; while the prominent Rannerdale Knot projects into Crummock Lake in front; and Honister Crag peeps over from behind. As the reader knows, the whole group may be studied from Scale Hill; and to the utmost advantage from the Station. (p. 86.) At Scale Hill Inn the travellers may close in comfort the third day of their circuit. 


\section{FOURTH TOUR.}

FROM SCALE HILL, BY HONISTER CRAG, TO KESWICK.

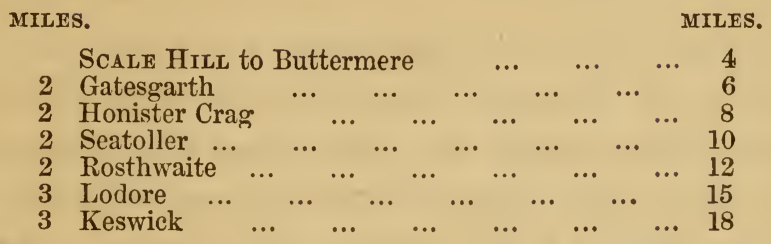

The road as far as Buttermere has been described (p. 84). But the attention of the traveller has hardly been sufficiently called to the stormy character of this central district, as shown by the aspect of the mountains. No where else are they so scarred with weather marks, or so diversified in colouring from new rents in the soil. Long sweeps of orange and grey stones descend to Crummock Water; and above, there are large hollows, like craters, filled now with deep blue shadows, and now with tumbling white mists, above which yellow or purple peaks change their hue with every hour of the day, or variation of the sky. The bare, hot-looking débris on the Melbreak side, the chasms in the rocks, and the sudden swellings of the waters, tell of turbulence in all seasons. The most tremendous waterspout remembered in the region of the lakes, descended the ravine between Grassmoor and Whiteside, in 1760. It swept the whole side of Grassmoor at midnight, and carried down everything that was lying loose all through the vale below, and 
over a piece of arable land at the entrance, where it actually peeled the whole surface, carrying away the soil and the trees, and leaving the rocky substratum completely bare. The soil was many feet deep, and the trees fullgrown. Then it laid down what it brought, covering ten acres with the rubbish. By the channel left, it appears that the flood must have been five or six yards deep, and a hundred yards wide. Among other pranks, it rooted up a solid stone causeway, which was supported by an embankment apparently as strong as the neighbouring hills. The flood not only swept away the whole work, but scooped out the entire line for its own channel. The village of Brackenthwaite, which stood directly in its course, was saved by being built on a stone platform, - a circumstance unknown to the inhabitants till they now saw themselves left safe on a promontory, while the soft soil was swept away from beside their very doors, leaving a chasm where the flood had been turned aside by the resistance of their rock. The end of the matter was, that the flood poured into the Cocker, which rose so as to lay the whole south-western plain under water for a considerable time.

On leaving Buttermere, and passing the very small chapel (which yet is "quite big" compared with the former one on the same site) the road up Buttermere Haws to Newlands is seen ascending to the left. The Lake of Buttermere is only a mile and a-quarter in length, and a little more than half-a-mile in breadth. The mountains which enclose it have been already named (p. 84.) The torrent that will be observed 


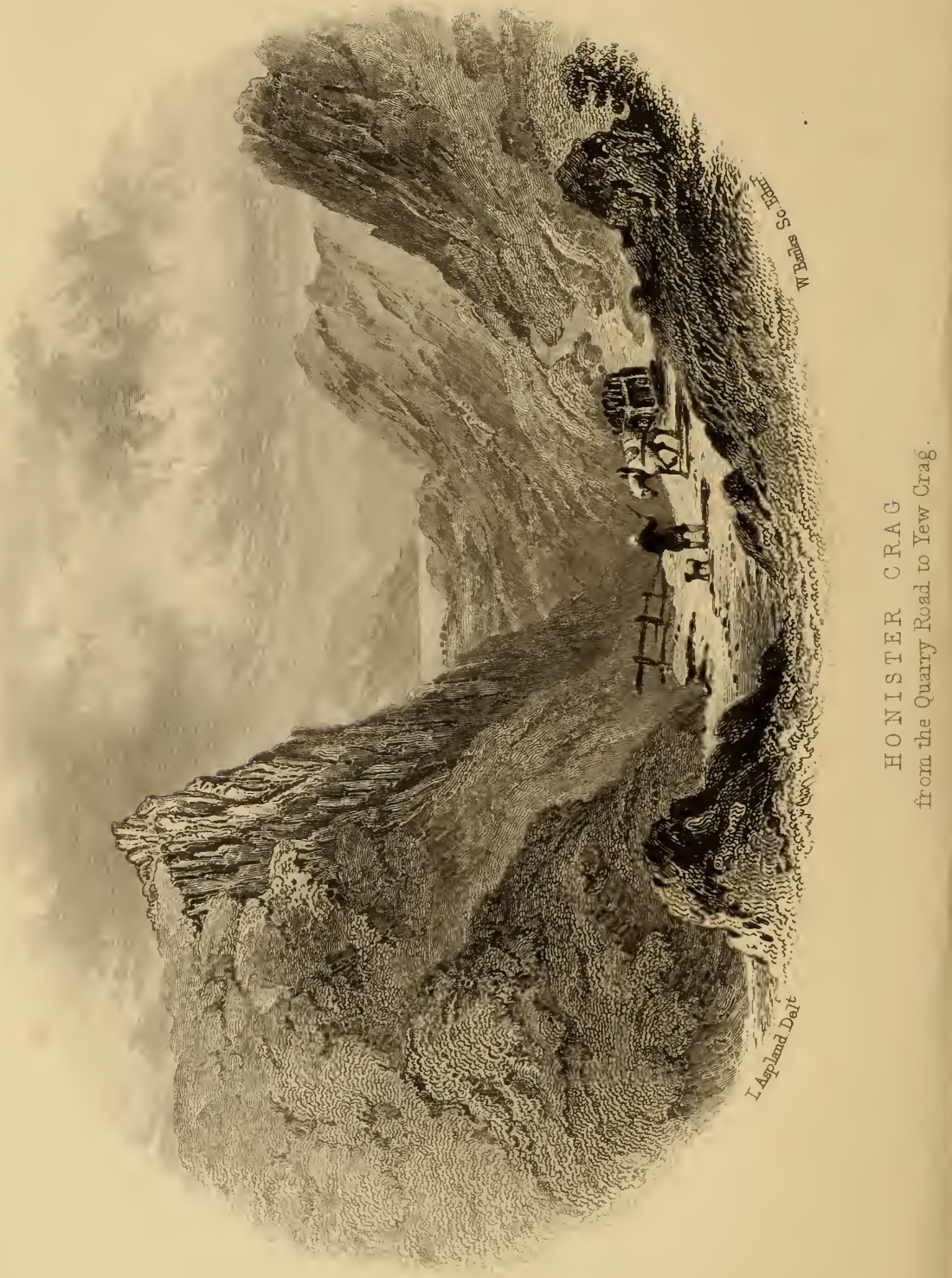


flowing down the steep into the lake is called (as others in the district are) Sourmilk Ghyll ; and it issues from Bleaberry, or Burtness Tarn, on the side of Red Pike. The pretty domain near the margin of the lake is Hasness (General Benson's.) Then comes Gatesgarth, - the farmstead whence the road to Scarf Gap is taken, by which, as we have told, London gentlemen and Kendal ladies have run into such extreme danger. From Gatesgarth begins one of the wildest bits of road in the district. It climbs Buttermere Vale, by an ascent at first gradual, and latterly extremely steep, to the base of Honister Crag. It is a vast stony valley, where sheep and their folds, and a quarryman's hut here and there, are the only signs of civilization. There are no bridges over the stream (the infant Cocker), which must be crossed many times; and where there are no stepping-stones, the pedestrian must wade. Every body walks up the last reaches of the ascent, - so steep and stony is the narrow road, and so formidable its unfenced state. The dark, stupendous, almost perpendicular, Honister Crag frowns above; and as the traveller, already at a considerable height, looks up at the quarrymen in the slate quarries near the summit, it almost takes his breath away to see them hanging like summer spiders quivering from the eaves of a house.

These quarrymen are a hardy race, capable of feats of strength which are now rarely heard of elsewhere. No heavily-armed knight, who ever came here to meet the Scot (and there were such encounters on this spot in the ancient border wars) carried a greater weight, or 
did more wonders in a day than these fine fellows. The best slate of Honister Crag is found near the top : and there, many hundred feet aloft, may be seen (by good eyes) the slate-built hovels of some of the quarrymen, while others ascend and descend many times between morning and night. Now the men come leaping down with their trucks at a speed which appears appalling to strangers. Formerly, the slate was brought down on hurdles, on men's backs: and the practice is still continued in some remote quarries, where the expense of conveyance by carts would be too great, or the roads do not admit of it. Nearly forty years ago there was a man named Joseph Clark at Honister, who made seventeen journeys, (including seventeen miles of climbing up and scrambling down,) in one day, bringing down 10,880 pounds of slate. In ascending he carried the hurdle, weighing eighty pounds; and in descending, he brought each time 640 pounds of slate. At another time he carried, in three successive journeys, $1,2 \dot{8} 0$ pounds each time. His greatest day's work was bringing 11,771 pounds; in how many journeys it is not remembered: but in fewer than seventeen. He lived at Stonethwaite, three miles from his place of work. His toils did not appear to injure him: and he declared that he suffered only from thirst. It was believed in his day that there was scarcely another man in the kingdom capable of sustaining such labour for a course of years.

In some places where the slate is closely compacted, and presents endways and perpendicular surface, the quarryman sets about his work as if he were going 
after eagle's eggrs. His comrades let him down by a rope from the precipice; and he tries for a footing on some ledge, where he may drive in wedges. The difficulty of this, where much of his strength must be employed in keeping his footing, may be conceived: and a great length of time must be occupied in loosening masses large enough to bear the fall without being dashed into useless pieces. But, generally speaking, the methods are improved, and the quarries made accessible by tracks admitting of the passage of strong carts. Still, the detaching of the slate, and the loading and conducting the carts, are laborious work enough to require and train a very athletic order of men. In various parts of the district, the scene is marked by mountains of débris, above or within which yawn black recesses in the mountain side, where the summer thunders echo, and the winter storms send down formidable slides into the vales below.

At the turn under Honister Crag, the vales behind disappear, and Borrowdale begins to open upon the eye; - at first in the form of a triangular bit of green level far below among the hills. By degrees, the overlapping mountains part asunder, and disclose more farmsteads and broader levels, till the fences are reached. Thence, it is a steep and rough descent upon Seatoller, by the side of the plunging and roaring stream, and its canopy of trees. Passing through the farm-yard at Seatoller, the travellers find themselves in Borrowdale, with only two miles more to Rosthwaite, (p. 77.) and eight to Keswick, and an excellent road all the way.

Thus have our travellers, in the space of four days, 
seen the greater part of the lakes and mountains. If they have used their eyes and minds, they must have observed something of the material, moral, and social changes going on perpetually in this once secluded corner of the United Kingdom.

As for the material changes, - those wrought in silence by Nature are of the same quiet, gradual, inevitable kind that have been going on ever since the mountains were upreared. She disintegrates the rocks, and now and then sends down masses thundering along the ravines, to bridge over a chasm, or make a new islet in a pool. She sows her seeds in crevices, or on little projections, so that the bare face of the precipice becomes feathered with the rowan and the birch : and thus, ere long, motion is produced by the passing winds, in a scene where all once appeared rigid as a mine. She draws her carpet of verdure gradually up the bare slopes, where she has deposited earth to sustain the vegetation. She is for ever covering with her exquisite mosses and ferns every spot which has been left unsightly, till nothing appears that can offend the human eye, within a whole circle of hills. She even silently rebukes and repairs the false taste of uneducated man. If he makes his dwelling of too glaring a white, she tempers it with weatherstains: if he indolently leaves the stone walls and blue slates unrelieved by any neighbouring vegetation, she supplies the needful screen by bringing out tufts of delicate fern in the crevices, and springing coppice on the nearest slopes. The most significant changes, however, are in the disposition of the waters of the region. The margins 
of the lakes never remain the same for half a century together. The streams bring down soft soil incessantly; and this more effectually alters the currents than the slides of stones precipitated from the heights by an occasional storm. By this deposit of soil new promontories are formed, and the margin contracts till many a reach of waters is converted into land, inviting tillage. The greenest levels of the smaller valleys may be seen to have been once lakes : and no one who looks down upon Grasmere, for instance, from the hill field behind the Hollins, can have any doubt as to what was once the extent of the waters. And, while Nature is thus closing up in one direction, she is opening in another. In some low-lying spot a tree falls, which acts as a dam when the next rains come. The detained waters sink, and penetrate, and loosen the roots of other trees; and the moisture which they formerly absorbed goes to swell the accumulation till the place becomes a swamp. The drowned vegetation decays and sinks, leaving more room, till the place becomes a pool, on whose bristling margin the snipe arrives to rock on the bulrush, and the heron wades in the waterlilies to feed on the fish which come there, nobody knows how. As the waters spread, they encounter natural dams, behind which they grow clear and deepen, till we have a tarn among the hills, which attracts the browsing flock, and tempts the shepherd to build his hut near the brink. Then the wild swans see the glittering expanse in their flight, and drop down into it; and the waterfowl make their nests among the reeds. This brings the sportsman; and a 
path is trodden over the hills; and the spot becomes a place of human resort. While nature is thus working transformations in her deeper retreats, the generations of men are more obviously busy elsewhere. They build their houses, and plant their orchards on the slopes which connect the mountains with the levels of the valleys: they encroach upon the swamps below them, and plough among the stones on the uplands, here fencing in new grounds, there throwing several plots into one: they open slate quarries, and make broad roads for the carriage of the produce: they cherish the young hollies and ash, whose sprouts feed their flocks, thus providing a compensation in the future for the past destruction of the woods. Thus, while the general primitive aspect of the region remains, and its intensely rural character is little impaired, there is perhaps scarcely a valley in the district which looks the same from one half-century to another.

The changes among the people proceed faster: and some of these changes are less agreeable to contemplate, however well aware we may be that they are to issue in good. Formerly, every household had nearly all that it wanted within itself. The people thought so little of wheaten bread that wheat was hardly to be bought in the towns. Within the last few years, an old man of eighty-five was fond of talking how, when a boy, he wanted to spend his penny on wheaten bread; and he searched through Carlisle from morning to evening before he could find a penny roll. The cultivator among the hills divided his field into plots, 
where he grew barley, oats, flax, and other produce, to meet the needs of his household. His pigs, fed partly on acorns or beech mast, yielded good bacon and hams; and his sheep furnished wool for clothing. Of course he kept cows. The women spun and wove the wool and flax, and the lads made the wooden utensils, baskets, fishing tackle, \&c. Whatever else was needed was obtained from the pedlars, who came their rounds two or three times a-year, dropping in among the little farms from over the hills. The first great change was from the opening of carriage roads. There was a temptation then to carry stock and grain to fairs and markets. More grain was grown than the household needed, and offered for sale. In a little while the mountain farmers were sure to fail in competition in the markets with dwellers in agricultural districts. The mountaineer had no agricultural science, and little skill; and the decline of the fortunes of the "statesmen," as they are locally called, has been regular, and mournful to witness. They haunt the fairs and markets, losing in proportion to the advance of improvement elsewhere. On their first losses, they began to mortgage their lands. After bearing the burden of these mortgages till they could bear it no longer, their children have sold the lands : and among the shopboys, domestic servants, and labourers of the towns, we find the names of the former yeomanry of the district, who have parted with their lands to strangers. Much misery intervened during the process of transition. The farmer was tempted to lose the remembrance of his losses in drink when he at- 
tended the fairs and markets. The capacity of the dalesmen in this respect, - in the quantity of strong liquor that they can carry - is remarkable; and they have only too good a training. Spirits are introduced on all occasions. At sales, of which there are many, every spring and autumn, in the dales, and which are attended by all the inhabitants who can go, for miles round, - glasses of spirit are handed round among the purchasers, all day long. The settling of accounts at Candlemas is attended by the same curse, - every debtor expecting his creditor to offer him the compliment of a glass of strong liquor. On that day, it is unpleasant to ladies to be abroad, near settlements where the Candlemas payments are making, - so many are the drunken people whom they meet. It is common to swallow the strong liquor undiluted, in considerable quantity. An old dalesman, welcome in Ambleside for his shrewdness, simplicity and originality, appeared one day at a house where the gentleman was absent, but the lady at home. The lady asked the visitor to sit down and await her husband's return, proposing to offer him some spirit and water meantime. He replied he wonnot be nice about t' first part e't' offer, but as tot' watter, it could be gitten at ony gate (way) side.

To return to the former condition of the "statesman." The domestic manufactures he carried to town with him, - the linen and woollen webs woven by his wife and daughters, - would not sell, except at a loss, in the presence of the Yorkshire and Lancashire woollens and cottons made by machinery. $\mathrm{He}$ became 
unable to keep his children at home; and they went off to the manufacturing towns, leaving home yet more cheerless - with fewer busy hands and cheerful faces - less social spirit in the dales-greater certainty of continued loss, and more temptation to drink. Such is the process still going on. Having reached this pass, it is clearly best that it should go on till the primitive population, having lost its safety of isolation and independence, and kept its ignorance and grossness, shall have given place to a new set of inhabitants, better skilled in agriculture, and in every way more up to the times. It is mournful enough to meet everywhere the remnants of the old families in a reduced and discouraged condition: but if they can no longer fill the valleys with grain, and cover the hillsides with flocks, it is right that those who can should enter upon their lands, and that knowledge, industry and temperance should find their fair field and due reward.

We have no fear of injury, moral or economical, from the great recent change, - the introduction of railways. The morals of rural districts are usually such as cannot well be made worse by any change. Drinking and kindred vices abound wherever, in our day, intellectual resources are absent: and nowhere is drunkenness a more prevalent and desperate curse than in the Lake District. Any infusion of the intelligence and varied interests of the townspeople must, it appears, be eminently beneficial: and the order of workpeople brought by the railways is of a desirable kind. And, as to the economical effect, - it cannot but be good, considering that mental stimulus and 
improved education are above every thing wanted. Under the old seclusion, the material comfort of the inhabitants had long been dwindling; and their best chance of recovery is clearly in the widest possible intercourse with classes which, parallel in social rank, are more intelligent and better informed than themselves.

In the pastoral valleys, the trouble occurs now and then that the milk will not churn. Elsewhere, the causes of this are understood, and cow and milk are treated accordingly. Not so here. The cow is at once concluded to be bewitched; and it is apprehended that she will spread the witchery to the whole dairy. So, instead of any sensible method, the remedy tried is depositing in the cowhouse some soil from the nearest churchyard. As it is probable that this fails, time is lost in other proceedings. Stirring with a stick from the rowan tree is one of the least troublesome. If the cows are distempered, it is actually a practice in many of the dales to light the "need fire." Notice being given throughout the neighbouring valleys, that the charm may be sent for if wanted, the need fire is produced by rubbing two sticks together. A great pile of combustible stuff is prepared; and the more smoke it can be made to give the better. When lighted, the neighbours snatch some of the fire to hurry home with, and light their respective piles. The cattle, diseased and sound, are then driven through the fire, as some of the Irish, by a remnant of paganism, charm their property, and even their children, by passing or snatching them through the fire, making 
strangers ask whether Moloch is ac'snowledged there still. It is said, in a certain Cumberland dale, that when a farmer had driven all his other live property through, he proceeded to drive his wife after the cows, saying he should then be safe from all distempers. If a cock crows in the night, horror and grief seize on the household:- some one is sure to die. If people meet a black ram, they turn their money for luck. They occupy their minds and waste their time in the silliest superstitions which keep true knowledge out. For the result, look at the productions of the region, - the torn and dirty wool, the sapless and scentless hay, allowed first to run to seed, and then to lie soaking and parching for weeks in the field, - the flour, the meat, the butter, the cheese, - look at any of these products in the more retired vales, and say whether intercourse with the world outside will not be a good thing for the fortunes of those within. To take only the last, - the cheese. After coming from the other grazing districts, and seeing how scientific a matter the management of a dairy has become, and what the best cheese is, the dairy management of Cumberland is marvellous. Our readers cannot be expected to believe the facts without good testimony: and we may refer them to such local publications as the "Lonsdale Magazine," where, (in Vol. ii. p. 13.) we are told that the Cumberland cheese is harder than buck-horn : and that in some places where the husbandmen wear clogs shod with iron, it is no uncommon thing to supply the absence of the iron with the crust of a dry cheese. There is plenty of testiniony to cheese striking fire 
like a flint. A soldier used a cheese paring for a flint; and a blacksmith at Cartmel avered that he struck sparks from a cheese while cutting it up with an axe. A tract of dry heather burned without intermission for three weeks, having been kindled by sparks from a cheese which had rolled from a cart on the road above, and bounded from crag to crag. These things are like the barbarism of two centuries ago. It is the railroad that must mend them. In a generation or two, the dale farms may yield wool that Yorkshire and Lancashire, and perhaps other countries, may compete for. The cheese may find a market, and the butter may be in request. And at the same time, the residents may find their health improved by the greater wholesomeness of their food; and, before that, their minds will have become stirred and enlarged by intercourse with strangers who have, from circumstances, more vivacity of faculty and a wider knowledge. The best, as well as the last and greatest change in the Lake District is that which is arising from the introduction of the railroad. 


\section{PART IV.}

\section{PASSES.}

IANGDALE, FROM BORROWDALE, BY THE STAKE PASS. - PATH TO EASEDALE. - PATH TO ESKHAUSE.

The top of the Stake Pass is five miles and a-half from Rosthwaite. The last house, - Stonethwaite, is left behind at the end of a mile. The path follows, and at length crosses, the stream, which is the infant Derwent, - finding its way down from Angle Tarn, lying high up in a recess of Bowfell. The rocky mass of Eagle Crag rises on the left; and further on, the curious stone called Black Cap. At the top of the Stake, the guide (who may be had from the inn at Rosthwaite) will point out the great summits, - the Scawfell Pikes, Bowfell, Hanging Knotts and Great Gable. Half a-mile of moorland leads to the descent on the Langdale side; a zigzag path which keeps near the stream that dashes down into Langdale. The 
traveller is under the shadow of Bowfell now, and in the very centre of the mountains. Four miles from the top of the Stake will bring him down to Langdale Head; and two miles more, to the farmhouse of Milbeck.

From that farmhouse, where travellers can make a good meal of farmhouse fare, there is one thing to be done without doubt; - to visit Dungeon Ghyll. As for the rest, this house is the point of departure in various directions, among three of which the traveller must make his choice.

Strangers who arrive untired generally go to the Ghyll while their ham and eggs are preparing. The green path on the hill side will be pointed out from the farm: and the traveller must take care not to make for the waterfall he sees in front. The path he wants tends to the left, till it reaches a fence and gate, when it turns sharp to the right; after which there is no possibility of losing the way. It presently joins the stream from the force, which leads up into a deep and dark fissure, - "Dungeon" and "Ghyll" both meaning a fissure. There is a well secured ladder, by which ladies easily descend to the mouth of the chasm; and when they have caught sight of the fall, they can please themselves about scrambling any further. There is the fall in its cleft, tumbling and splashing, while the light ash, and all the vegetation besides is everlastingly in motion from the stir of the air. Above, a bridge is made, high aloft, by the lodgment of a block in the chasm. The finest season for visiting this force is in a summer afternoon. Then the sun streams in obliquely, 
- a narrow, radiant, translucent screen; itself lighting up the gorge, but half concealing the projections and waving ferns behind it. The way in which it converts the spray into sparks and many-coloured gems can be believed only by those who have seen it.

The three ways from Milbeck are first down Langdale to its junction with the Brathay valley, or by High Close to Grasmere: secondly, by Wall End to Blea Tarn, and the Fellfoot road: and thirdly, by Stickle Tarn, up Harrison Stickle, or over into Easedale. We have little to observe 'about the first, Langdale having been described (p. 48) as seen from High Close. Langdale Chapel is a primitive hamlet, where the old character of the district is well preserved. The little chapel is a good specimen of the churches of the vales. A few years since, the rotten old pulpit fell, with the clergyman, Mr. Frazer, in it, just after he had begun his sermon from the text "Behold, I come quickly." The pulpit fell on an elderly dame, who escaped wonderfully. Mr. Frazer, as soon as he found his feet, congratulated her on surviving such an adventure: but she tartly refused his sympathy, saying, "If I'd been kilt, I'd been reet sarrat, (rightly served), for you'd threatened ye'd be comin doon sune." Near this chapel is the Thrang Slatequarry, where the stranger should look in and see what a mighty excavation has been caused by the demand for this fine slate. Just beyond the chapel, the roads part, - that which ascends to High Close climbing the hill to the left.

As for the second road from Milbeck, - the main 
inducement is the valley in which Blea Tarn lies, -- the scene of those books of Wordsworth's Excursion which relate to the Solitary. The very rough road scrambles up from Langdale, by Wall End, to the upland vale where the single farmhouse is, and the tarn, and the stone, "like a ship, with keel upturned," which is lodged in a stream near to the tarn. Some people have unaccountably fixed on the Bowder Stone to answer this description; but, besides that the Bowder Stone is far away, it rests on its edge, instead of its "keel " being "upturned." "The two huge peaks, that from some other vale peer into this," are the Langdale Pikes; and very fine is the view of them from this wild and somewhat dreary hollow. Since the Excursion was written, large plantations of larch have arisen; but they do not much ameliorate the desolation of the place. The road descends the common to Little Langdale Tarn; whence it is described, in a reverse manner, in its course to Colwith Force, Skelwith, and Ambleside, at p. 115.

In the third direction lies the way up the Pikes, and over into Easedale. The guide from Milbeck will take the traveller up the peat road to Stickle Tarn, famous for its trout, and much beloved by anglers. Its circular basin, brimming with clear water, lies finely under the steep rocks of Pavey Ark. There is nothing amidst this mountain scenery more interesting than its tarns. Their very use is one which gratifies one's sense of beauty. Their use is to cause such a distribution of the waters as may fertilize without inundating the lands below. After rains, if the waters came down 
all at once, the vales would be flooded, - as we see, very inconveniently, by the consequences of improved agricultural drainage (p. 17). The tarns are a security, as far as they go; and at present the only one. The lower brooks swell after rain, and pour themselves into the rivers, while the mountain brooks aloft are busy in the same way, emptying themselves into the tarns. By the time the streams in the valley are subsiding, the upper tarns are full, and begin to overflow; and now the overflow can be received in the valley without injury. As for their aspects, under all lights, and in all weathers, they must be studied on the spot, for no description can afford any impression of the truth to highway tourists.

If the traveller means to ascend Harrison Stickle, (the higher of the Langdale Pikes,) it will be from this point. The summit of the Pike is 2,409 feet above the level of the sea. The height is not very great; but the view is interesting, from being unlike most others that can be obtained, - extending over the level country to the south and south-east, while commanded by the loftiest peaks of the district. Passing the way up the Pike, the moorland path leads over into Easedale, and down upon Easedale Tarn, which has been noticed at p. 51. There is a way down into Borrowdale also, by crossing Codale Fell, and getting into the Stake road.

There are other mountain paths out of Langdale. There is one into Easedale, easier than that just described, and commonly used in good weather. It was by this track that the unfortunate couple, - the 
Greens, whose story is so well known, - were lost in the snow, on their return from a sale in Langdale, to their home and six children in Easedale.

There is also a very rough path at Langdale Head up Rosset Ghyll, answering on the left to the Stake road on the right. It at once catches the eye; and the invariable question of the stranger is which of the two is the Stake. This track leads by Esk Hause and Sprinkling Tarn to the Sty Head Pass. This is truly a glorious mountain walk. From Esk Hause, there is a singular view, composed of three lines of landscape. One begins with Borrowdale, lying immediately below, and extends to Derwentwater and Bassenthwaite, past Skiddaw, in full glory, and on over the whole intervening plain, to the Solway and the Scotch mountains. This is the north-western view. - The opposite, or south-eastern one, begins with Langdale, and proceeds by the opening of the Brathay valley and Windermere, till it is closed in by Ingleborough, in Yorkshire. The third, and intermediate view, is down Eskdale, past its verdure and its cataracts, past the sands, past lonely Blackcombe, to the broad sea. When we were on Esk Hause, the spectacle of these three lines of landscape was remarkable. Towards Keswick, the atmosphere was thick, just to the degree that gave a visionary character to the long perspective. The lake of Derwentwater was hardly distinguishable from its shores, so that the wooded islands and the town of Keswick lay as if in air, still and unsubstantial. In the direction of Eskdale, all was bright and glittering; while from Langdale and the head of Borrowdale the 
white mists came tumbling out towards us, as if to stifle us; and nothing could be seen, except at intervals, when a whiff of wind disclosed long sweeps of the sides of the valleys, and stretches of the streams and fields below. It is these changes that give a singular charm to this mountain district. The residents of the valleys, in their occasional ascents to these heights, never see the scene twice alike, - the great landmarks themselves being scarcely recognizable but by certain incidents of their forms. 


\section{II.}

STY HEAD PASS, FROM WASTDALE TO BORROWDALE.

We have noticed the eastern prong of the fork into which Glaramara divides the head of Borrowdale. We now have to notice the western, - the Sty Head Pass. The Stake Pass descends, as we saw, upon Stonethwaite. The Sty Head Pass descends upon Seathwaite, - each of these farms being the last dwelling at the head of the dale.

Antiquarians tell us that Borrowdale was anciently called Boredale, "having its name probably from the wvild boars which used, in former times, to haunt the woody part of Wastdale Forest; the hill above it being called Sty Head, where the swine were wont to feed in the summer, and fall down in autumin into this dale, where they fed upon nuts and acorns. Here are large flocks of sheep; and anciently were mines of lead and copper. Here also, in a very high and perpendidular rock called Eagle Crag, is every year an eyrie or nest of eagles." So says the old history.* But the traveller will find no swine near Sty Head now, summer or winter. No creature comes to drink at the tarn, - the little clear rippling lake, where the mountaineer throws himself down to rest on the bank, when heated by the ascent from the vales. He has found

* History and Antiquities of Westmorland and Cumberland, ii. p. 69. - Nicholson and Burn. 


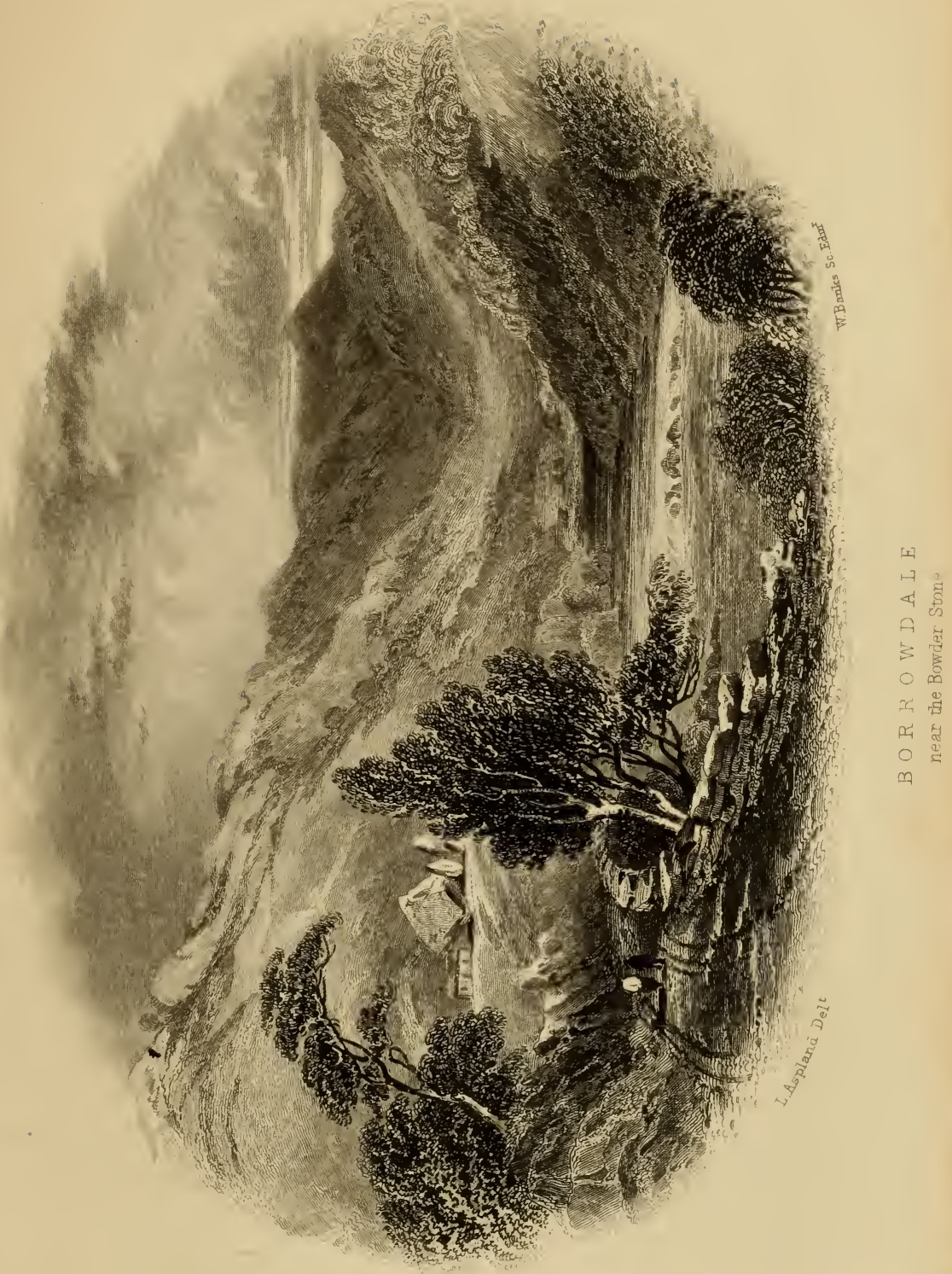


everything sunny and dry, perhaps; but here he sees, by the minute diamond drops resting thick on the grass, that a cloud has lately stooped from its course, and refreshed the verdure in this retreat. It looks very tempting - this bright sheet of water; but no creature now comes to drink, unless a sheep may have strayed far from the flock, and in its terror may yet venture to stoop to the water, with many a start and interval of listening, till, at the faint sound of the distant sheep dog, it bounds away. The solitude is almost equally impressive whether the traveller comes up from the one dale or the other; but perhaps the most striking to him who comes from Wastdale, because he has rather more lately left the dwellings of men. He ascends from Wastdale Head, by the steep path clearly visible from below, up the side of Great Gable. At the top of the pass, the view behind is extremely fine, - the dale lying 1,000 feet below, while the precipices of Scawfell rise 2,000 feet over head. The rill from Sprinkling Tarn is close by, and it leads to this Sty Head 'Tarn, where the boars used to come to drink. Long after the boars were gone, the eagles came hither: and this was one of their last haunts. The eagles which gave their name to the crag in Borrowdale, being disturbed, settled themselves on a rock at Seathwaite, and at length crossed the ridge into Eskdale. The disturbance was of course from the shepherds, who lost so many lambs as to be driven desperate against the birds. There was no footing on the crag by which the nest could be reached; so a man was lowered by a rope sixty yards 
down the precipice. He carried his mountain staff with him; its spiked end being the best weapon against the birds. Ife did not expect to kill the old ones; but year after year the eggs or the young were taken. If he brought the young away alive he had the birds for his pains: if the eggs, every shepherd gave five shillings for every egg. It is said that no more than two eggs were ever found at one time. The nest was made of twigs, and lined with a sort of grass from the clefts of the rock. When the fowler failed, and the eaglets were reared, they were led away, as soon as strong enough, by the parent birds, - no doubt to settle in some other spot; and the parents returned without them. One of this pair was shot at by the master of a sheep dog which had been actually carried some distance into the air by it, escaping only by its flesh giving way. The shot took effect, but the eagle vanished. About a week after, it was found lying on the grass on the uplands at Seatoller, nearly starved. Its bill had been split by the shot, and the tongue was set fast in the cleft: it could not make much resistance, and was carried home captive. But, when relieved and restored, it became so violent that it was necessarily killed. Its mate brought a successor from a distance, a ruuch smaller bird, and of a different species. They built, however, for fourteen more years in Borrowdale, before they flew over to Eskdale. They were not long left in peace there; and, when the larger bird was at length shot, his mate disappeared entirely. Such devastation as was caused by these birds is not heard of now; but while there are 
crags aloft and lambs in the vales, there will be more or fewer, nobler or meaner, birds of prey. We are unable to ascertain positively, amidst conflicting testimony, whether any eagles at all remain in the region. It appears that one has certainly been seen within ten years ; and three gentlemen, two of whom are travelled men, and not likely to be mistaken in such a matter, declare that, four years ago, they saw one sweep down from Scandale Fell into Kirkstone Pass, and rest on a crag in the vale, some way above Brothers' Water. There is, however, a preponderance of disbelief of there being now any nest and settlement of eagles anong the mountains of Westmorland and Cumberland.

The descent upon Stockley bridge is easy; and the bridge itself was, a few years since, a favourite subject for sketches. A more picturesque one we never saw : but it has been spoiled in the repairing. - As he proceeds, the traveller will find no "nuts and acorns" in this "Boredale," nor any remarkable number of swine. But he may see the place, - if he looks up the hillside to the left, - whence was drawn the modern product that has in modern times, distinguished the dale, - the blacklead of which the Keswick pencils are made. It is understood that the productiveness of the mine has much lessened; and the works are, we believe, often suspended; but, while the best ore brings 30 s. per lb., there will be more or less perseverance in seeking it. The heaps of rubbish, high up the mountain, show the spot. In the clay slate of the mountain is a bed of greenstone rock; and "nests" or "sops" or "bellies" of black lead are found in the greenstone. 
The plumbago is the finest ever discovered: but there is great uncertainty about finding it. At one time, a mass of it was discovered lying along like a mighty tree, the thicker part being of the finest quality, and the ramifications of a poorer, till, at the extremities, it was not worthy even to clean stoves. At other times the searchers have been altogether at fault, for a long time together. There was a time when the value of this plumbago was so little known that the shepherds used it freely to mark their sheep : and next, the proprietors were obtaining from thirty to forty shillings a pound for the lead of one single "sop" which yielded upwards of twenty-eight tons. Those were the days when houses were built at the entrance, where the workmen were obliged to change their clothes, under inspection, lest they should be tempted to carry away any of the precious stuff in their pockets.

Under the mine, (the wad) and a little onward, amidst the copsewood, are the dark tops of the Borrowdale yews to be seen, - the " fraternal four," which, as Wordsworth tells us, form "one solemn and capacious grove." The size attained by the yew in this district is astonishing. One which for many years lay prostrate at the other end of Borrowdale, measured nine yards in circumference, and contained 1,460 feet of wood. The famous Lorton yew (p. 87.) has about the same girth; and one of these four measures seven yards round, at four feet from the ground.

At Seatoller, the roads which part off right and left are familiar to the traveller who has accomplished the preceding excursions, - the one leading to Rosthwaite and the other to Honister Crag. 


\section{III.}

ASCENT OF SCAWFELL.

The ascent of Scawfell is sometimes made from the Sty Head Pass ; sometimes from Lingmell ; and sometimes from Langdale, whence the path meets that from Sty Head on Esk Hause. From Esk Hause the summit of the Pike is visible; but still, care is necessary not to ascend the wrong summit. There are four summits which collectively go under the name of Scawfell; viz, the most southerly, which is called simply Scawfell; Scawfell Pike, which is sixty feet higher, and the highest mountain in England (3,160 feet:) and the lower hills, Lingmell and Great End, - the last being the northernmost, and fronting Borrowdale. The Ordnance surveyors set up a staff on a pile of stones on the highest peak; so that there need be no mistake henceforth. The two summits are about three-quarters of a-mile apart, in a straight line; but the great chasm between them, called Mickledore, renders a wide circuit necessary. There have been fool-hardy persons who have passed Mickledore without losing their lives; and there are strangers, almost every season, who attempt the ascent without a guide. These last usually pay the penalty of their rashness in hours of uneasy wandering and excessive fatigue. When they think they see their way clearly enough, they are pretty sure to find themselves brought up on the verge of a chasm, and com- 
pelled to "try round" many times before they succeed. If darkness comes on, there is nothing to be done but to wait for daylight where they are. Another reason for having a guide is that the mountains around are not recognisable by their forms, - so great is the change caused by their being looked at from above. By map and compass they may be made out: but the summit is usually windy: and much time and trouble are saved by the information needed being ready at one's elbow.

The summit is bare of every thing that grows, except moss. Not a blade of grass is to be seen : and it follows that the herdsman and shepherd never have to come here after their charge. Blocks and inclined planes of slate rock, cushioned and draped with mosses, compose the peak. As for what is seen from it, the best service to the stranger is still to copy portions of that "Letter to a friend" which Mr. Wordsworth published many years ago, and which is the best account we have of the greatest mountain excursion in England. The weather was, however, unusual. The guide said, when on the summit, "I do not know that in my whole life, I was ever, at any season of the year, so high upon the mountains on so calm a day." It was the seventh of October.

"On the summit of the Pike," says the letter, "which we gained after much toil, though without difficulty, there was not a breath of air to stir even the papers containing our refreshment, as they lay spread out upon a rock. The stillness seemed to be not of this world. We paused, and kept silence to listen, and 
no sound could be heard. The Scawfell cataracts were voiceless to us; and there was not an insect to hum in the air. The vales which we had seen from Esk Hause lay yet in view, and, side by side with Eskdale, we now saw the sister Vale of Donnerdale terminated by the Duddon Sands. But the majesty of the mountains below, and close to us, is not to be conceived. We now beheld the whole mass of Great Gable from its base - the Den of Wastdale at our feet - a gulf immeasurable; Grasmire, and the other mountains of Crummock; Ennerdale and its mountains; and the sea beyond!" * * * "While we were gazing around, 'Look,' I exclaimed, 'at yon ship upon the glittering sea!' 'Is it a ship?' replied our shepherd guide. 'It can be nothing else,' interposed my companion. 'I cannot be mistaken; I am so accustomed to the appearance of ships at sea.' The guide dropped the argument; but, before a minute was gone, he quietly said, 'Now, look at your ship - it is changed into a horse.' So it was; a horse with a gallant neck and head. We laughed heartily; and I hope, when again inclined to be positive, I may remember the ship and the horse upon the glittering sea; and the calm confidence, yet submissiveness, of our wise man of the mountains, who certainly had 'more knowledge of the clouds than we, whatever might be our knowledge of ships.

"I know not how long we might have remained on the summit of the pike, without a thought of moving, had not our guide warned us that we must not linger, for a storm was coming. We looked in vain to espy 
the signs of it. Mountains, vales and sea were touched with the clear light of the sun. 'It is there! said he, pointing to the sea beyond Whitehaven' and there we perceived a light vapour, unnoticeable but by a shepherd accustomed to watch all mountain bodings. We gazed around again, and yet again, unwilling to lose the remembrance of what lay before us in that mountain solitude; and then prepared to depart. Meanwhile, the air changed to cold, and we saw that tiny vapour swelled into mighty masses of cloud, which came boiling over the mountains. Great Gable, Helvellyn and Skiddaw were wrapped in storm; yet Langdale, and the mountains in that quarter, remained all bright in sunshine. Soon the storm reached us; we sheltered under a crag; and almost as rapidly as it had come, it passed away, and left us free to observe the struggles of gloom and sunshine in other quarters. Langdale had now its share; and the Pikes of Langdale were decorated by two splendid rainbows. Before we again reached Esk Hause, every cloud had vanished from every summit."

We cannot do better than stop at these auspicious words. May the tourist who reads this on the Pike see every cloud vanish from every summit! 
The other exit from Wastdale Head is by the road to Scarf Gap, already referred to as having been found dangerous by inexperienced travellers. A rough footroad leads through the valley of Mosedale, between Kirkfell and Yewbarrow, till it enters Gillerthwaite, at the head of Ennerdale. Kirkfell and the stream being kept on the right, the track passes between Kirkfell and the Pillar. Coming down into Gillerthwaite, the view is beautiful. Great Gable and Kirkfell close in the dale at its head; High Stile and Red Pike are in front, and Gillerthwaite is below, with its circular green level, dropped over with wood, its farmhouse and stream, and the lake at the other end. Behind, the wild valley of Mosedale winds away between Kirkfell and Yewbarrow, and discloses the great summits of Scawfell and Bowfell. The Pillar is 2,893 feet high, and inaccessible, from its craggy and precipitous character. The path leads along the Pass called Blacksail to a sheepfold on the little river Liza, which falls into Ennerdale Lake : at that fold the stream will be crossed, and an indistinct path will be seen crossing a hollow in the direction of Buttermere. That hollow is Scarf Gap; and the path leads out upon Gatesgarth, at the head of Buttermere. From Gatesgarth it is four miles to Seatoller in Borrowdale, one mile to 
Honister Crag, and two miles from the Inn at Buttermere. As nearly as we can make out, the walk from Wastdale to Gatesgarth is somewhat short of twelve miles. Most of it must be traversed on foot, though a horse may be led, to be occasionally mounted. 


\section{V.}

GRISEDALE. - ASCENT OF HELVELLYN.

There is a charming walk of ten miles from Patterdale to Grasmere (from inn to inn) by Grisedale, which may as well be enjoyed by the pedestrian traveller, whether he chooses to ascend Helvellyn or not. Grasmere and Grisedale have the same derivation,-Gris being the old Saxon for wild swine: and these are therefore the lake and the valley of the wild boar. A deep and still retreat must both have been in the days of wild boars.

From Patterdale, the traveller crosses Grisedale beck, and ascends by a steep well-wooded road to the table-land of Grisedale. The old hollies in the woods are remarkably fine. At every step the grandeur and gloom overhead increase, - the path leading directly under the frowning Helvellyn. The Greenside lead mines are about half way up, under Striding Edge; and the tourist is likely to mistake the track to the mines for his own road: but he must keep the stream to the right, - in other words, he must keep on the right bank of the stream for some way further. The path crosses and recrosses the beck in climbing the steep ascent to the tarn; but there is no further danger of losing the track. The view of Place Fell behind is fine, as seen through the steep sides of the dale; and north-westwards, the mountains about the 
Vale of Newlands are seen peeping between Seat Sandal, and Helvellyn. The tarn lies under the east flank of Seat Sandal in a deep hollow; and a more sweet and solemn resting place than Grisedale Tarn is not perhaps to be found among these mountains. A wall runs along the ridge; and through the gate in that wall the track leads down to Grasmere. The views are gayer and more extensive by far than those presented by the other half of the pass. The mountains seen thence are the Langdale Pikes and Coniston Oid Man, with Scawfell and Bowfell predominant. The first part of the descent is steep, and the latter part gradual and pleasant, over grass, and finally between fences and among farmhouses, till the path comes out upon the mail road, opposite Helm Crag, and some way above the Swan at Grasmere:

If the traveller ascends Helvellyn from Grisedale, he must take the road to the right, soon after entering the dale, in order to reach Red Tarn. Some sturdy climbers go on to Grisetale Tarn, and climb the mountain from its head: but it is best to take the road to Red Tarn, either by Grisedale or Glenridding, - the next turn from Patterdale. It is possible to go on ponies to within half an hour's walk of the summit. Red Tarn lies 600 feet immediately below the highest point, parted off from Grisedale by the rocky ridge of Striding Edge, and surmounted in the opposite direction by the similar ridge of Swirrel Edge. This last is the ridge along which the track lies, - the conical head of Catchedecam being its termination. This part of the ascent is that which is most trying to unaccus- 
tomed nerves, though there is no real danger. It was in trying the other ridge, (which it is always foolhardy to do,) that Charles Gough fell from the precipice, where his corpse was watched by his dog for two months, till it was found. Every one knows the story, as told by Wordsworth and Scott. There are stakes near the tarn where horses are fastened, and then there is a steep scramble to the top.

There are precipices on the east of the summit; but its mossy plain slopes gently towards the west. No mountain in the district is, we believe, so often climbed. Its central situation renders the view attractive on every account ; it is very conspicuous; and it is not difficult of ascent. According to the Ordnance Surveyors, its height is 3,055 feet above the level of the sea ; that is, 33 feet higher than Skiddaw, and rather more than 100 feet lower than Scawfell Pike. There are three modes of ascent from the Grasmere side; - the one by Grisedale Tarn : another from Wythburn; and a third further on from Legberthwaite. The one from Wythburn is the shortest, but by much the steepest, - the track beginning at once to climb the hill opposite the Nag's Head. The gushing stream which crosses the mail road near the Nag's Head comes down from Brownrigg's well, - the spring which refreshes the traveller on his way up or down, bursting from the mountain side within 300 yards of the summit. There are two cairns on two summits, not far apart, from between which, in an angle in the hill, the best view to the north is obtained. These Men, (as such piles of stones are called) mark the 
dividing line between Cumberland and Westmorland. Northwards, the view is bounded by the Scotch mountains, with the Solway at their feet. Nearer stands Saddleback, with Skiddaw a little to the left. Kepel Cove Tarn lies below, with Catchedecam on the right. Eastwards, Red Tarn lies immediately below, between its two solemn precipices. Ullswater shines beyond, its nearer bank fringed by Gowbarrow Park; and Crossfell closes in the view afar. The Troutbeck mountains here peep over Striding Edge. Kirkstone and Fairfield rise to the south; and over the latter, there is a peep at Windermere, and sometimes, in clear weather, a glimpse of Lancaster Castle. Esthwaite Water and the sea in Morecambe Bay are seen at the same time. Blackcombe is caught sight of through Wrynose Gap; and the Coniston range and Langdale Pikes lead the eye round to the superior summits at the head of Wastdale and Buttermere. Even Honister Crag is seen, in a hollow, a little to the left of Cat Bells. Derwentwater is not seen : nor, from the higher Man, either Thirlmere or Bassenthwaite; though the two last are visible from the lower Man. Six lakes are seen, besides many tarns:- Ullswater, Windermere, Esthwaite Water, Coniston, Bassenthwaite and Thirlmere. Angle Tarn is particularly conspicuous, while its neighbour, Hays Water, is hidden in its hollow under High Street. The streams it sends down to Brothers' Water are however, very conspicuous when the sun is upon them. 
CONISTON OLD MAN.-WALNA SCAR.

There is one more which the tourist would not excuse our omitting. He wants to see the copper mine and the series of tarns on Coniston Old Man; and he hears it said, and very truly, that the prospects are finer than any but those from Scawfell and Helvellyn, - if not, indeed, finer than the latter.

The ascent is best made by following the Walna Scar road which leads from Coniston into Seathwaite. When the traveller has left the bright and prosperous environs of Coniston behind him, and entered upon the moor, he begins to feel at once the exhilaration of the mountaineer. Behind him lies a wide extent of hilly country, subsiding into the low blue ridges of Lancashire. Below him he sees, when he turns, here and there a reach of the Lake of Coniston, - gray, if his walk be, as it should be, in the morning: gray, and reflecting the dark promontories in a perfect mirror. Amidst the grassy undulations of the moor, he sees, here or there, a party of peat-cutters, with their crate: and their white horse, if the sun be out, looks absolutely glittering, in contrast with the brownness of the ground. It is truly a wild moor; but there is something wilder to come. The Coniston Mountain towers to the right, - and the only traces of human existence that can be perceived are the tracks which wind along 
and up its slopes, - the paths to the coppermine, and a solitary house, looking very desolate among its bare fields and fences. The precipice called Dow (or Dhu) Crag appears in front ere long; and then the traveller must turn to the right, and get up the steep mountain side to the top, as he best may. Where Dow Crag and the Old Man join, a dark and solemn tarn lies beneath the precipice, as he will see from above, whence it lies due west, far below. Round three sides of this Gait's Tarn, the rock is precipitous; and on the other, the crags are piled in grotesque fashion, and so as to afford, - as does much of this side of the mountain, - a great harbourage for foxes, against which the neighbouring population are for ever waging war. The summit is the edge of a line of rocks overhanging another tarn, - Low Water, - which is 2,000 feet above the sea level, while the summit of the Old Man is 2,632. On this rock, a "Man" formerly stood; but it was removed by the Ordnance Surveyors, who erected another, much inferior in convenience; for the first contained a chamber, welcome to shepherds and tourists overtaken by bad weather. The mountain consists chiefly of a very fine roofing slate, from which a large tract of country is supplied, and in which a very important trade was formerly carried on. Several of the quarries are now deserted. From the earliest recorded times, there have been works here for the extraction of copper; and at present it is no unusual thing for $£ 2,000$ per month to be paid away in wages. The works commence at about half a-mile up the mountain, on its east side; and there is a large estab- 
lishment of sheds, shops and offices, clustered at the upper end of a basin among the hills. If the traveller desires to explore the mines, he can descend on that side of the mountain. Meantime, looking abroad from his perch, he sees, (beginning from Gait's Tarn) Devoke Water, in a line with Gait's Tarn, to the west. It is said that the trout in that lake are the best known; and tradition declares that the comfortable abbots of Furness imported them from Italy. There is a fine stretch of sea visible, with the Isle of Man, conspicuous in good weather. We need not recapitulate the names of the chief mountains. Suffice it that Ingleborough is visible in one direction, and Lancaster Castle again in another; and in clear weather, Snowdon. The number of tarns within view is remarkable. We have mentioned Gait's Tarn and Low Water. Beyond the latter lies Seathwaite Tarn, whence the infant Duddon issues. Stickle Tarn is conspicuous, lying under Pavey Ark. In a hollow of the mountain, on its north-east side, lies Lowes Water. Only the nearer lakes are seen; but there is a glorious stretch of sea; and, when the estuaries are full, the coast is a beautiful spectacle. The shores of Coniston and Windermere, studded with woods and dwellings, are the nearer beauties.

The finest descent, though the longest, is by the ridge of Wetherlam, above Levers Water, descending into Tilberthwaite, and returning to Coniston through Yewdale, noticed at p. 27. 


\section{VII.}

HAWES WATER.-PASS OF NANBIELD.

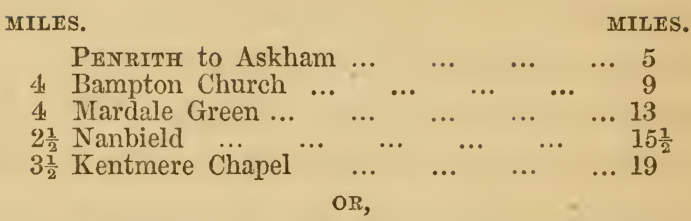

Mardale, by Nanbield and High Street, to Troutbeck inn, 6 miles.

There remains but one lake to be noticed, and that is Hawes Water, which is less visited than any other in the district. It is beautiful, but rather out of the way, except to visitors who come by Penrith; as they are usually bent on seeing at once the most celebrated points of scenery. Penrith is a neat little town, busy, from being the great thoroughfare of the district, but not particularly interesting, except from some Druidical remains in the neighbourhood, a curiosity in the churchyard, and the vicinity of Brougham Castle. The circle called Long Meg and her daughters is six miles from Penrith; and no relic of the kind in England is better worth a visit. In the churchyard of Penrith is the monument about which nobody really knows any thing, though it goes by the name of the Giant's Grave. It consists of two stone pillars, with four slabs between them, set up on edge. There are some undecipherable carvings on the upper part of the pillars. This was the monument which Sir. Walter Scott's 
family could not get him past, (though they had all seen it "dozens of times,") when, fuiling and infirm, he set out on his last sad journey, in pursuit of health. Passing through Penrith, he would see the Giant's Grave; and thither he limped, to wonder once more what it could mean.

The parish of Brougham, Burg-ham (meaning Castle-town) was the Brovacum of the Romans, where, as we learn from Nicolson and Burn, they had a company of Defensores, and left many tokens of their presence in antiquities which have come to light from time to time. The Village of Brougham passed into the hands of the Veteriponts in the reign of John or Henry III. The Castle of Brougham has been held by the Veteriponts, Cliffords and Tuftons, and is now the property of the Earl of Thanet. It is now in ruins; and fine ruins they are. They stand at the confluence of the Eamont and Lowther Rivers, at the distance of a mile from Penrith.

Brougham Hall, the seat of Lord Brougham, is within a mile and a-half of Penrith. The traveller should walk along the river bank from the bridge at Brougham Hall to Askham, and then ascend the steep bank of red sandstone, overshadowed by trees, to the park of Lowther Castle. The grounds here are fine; especially the terrace, which affords a noble walk. It is very elevated; broad, mossy, shady, breezy, and overlooking a considerable extent of country, - some of which is fertile plain, and some undulating surface, the margin of the mountain region. The most remarkable feature of this landscape is perhaps the hol- 
low, within which lies Hawes Water. The park has some fine old trees; and the number and size of the yews in the grounds will strike the stranger. But lasting injury was done to the woods by the hurricane of 1839 , which broke its way straight through, levelling every thing in its path. On the road from Askham to Bampton, the high grounds of Lowther present on the left a nearly straight line of great elevation, along which runs the park wall, almost to the extremity of the promontory. From a distance, it looks the most enviable position for a park that can be imagined.

Hawes Water lies about four miles from Askham. It is little more than three miles long, and about half a-mile broad. One side is richly wooded; the other nearly bare : and a pair of bold promontories threaten to cut it in two, in one part, where the passage is only two or three hundred yards wide. Round the head of the lake cluster the great mountains of Harter Fell, High Street, Kidsty Pike and others, leaving space among the skirts for the exquisite little valley of Mardale. Those who are able to obtain one of Lord Lonsdale's boats for the traverse of the lake may think themselves fortunate; for this is, of course, the most perfect way of seeing the surroundings of so small a sheet of water : and all other persons are deprived, by prohibition, of the means of doing so. There are some good houses on the shores and at the further end; but the occupants who live on the very brink are not allowed to keep any sort of boat. His lordship's boats are said to be procurable for the asking; but the preliminaries are a hindrance. The walk along the lake side is, how- 
ever, easy and agreeable enough. The road skirts the western bank. The crags which are sprinkled or heaped about the head of the lake are very fine. They jut out from the mountain side, or stand alone on the green slopes, or collect into miniature mountain clusters, which shelter tiny dells, whence the sheep send forth their bleat. There is a white house conspicuous at the head of the lake which is not the inn, however the tired traveller may wish it were. The inn at Mardale Green is a full mile from the water; and sweet is the passage to it, if the walker be not too weary. The path winds through the levels, round the bases of the knolls, past the ruins of the old church, and among snug little farms, while, at one end of the dale is the lake, and the other is closed in by the passes to Kentmere and Sleddale; and the great Pikes tower on either hand. The stream which gushes here and pauses there, as it passes among rough stones or through a green meadow, comes down from Small Water, reinforced by a brook from Blea Water on High Street, which joins the other a little above Mardale.

The hostess at Mardale Green Inn will make her guests comfortable with homely food and a clean bed: and the host will, if necessary, act as guide up the passes. The small green level which from the mountains looks such a mere speck, is of some importance at a distance. It actually sends 3,000 pounds of butter weekly to Manchester by the railway. The carrier's waggon picks up the baskets from the scattered dwellings in the dale, and transmits no less than thirty cwts. per week to the Manchester folk. 
The traveller must either go back the way he came, or climb out of the dale at the head, whence three tracks branch off from the top of the pass of Nanbield. One of these tracks turns to the left before reaching Small Water, and goes down into Long Sleddale, - to follow which we know of no sufficient inducement, unless it be that the way is practicable for a horse, which the others are not. Another path ascends, by the pretty Blea Tarn, the slope of High Street on the right, where the Roman road runs along the ridge. The third goes forward past Small Water, and drops into Kentmere, whence it is easy to strike over the fells into Troutbeck. The choice will depend much on weather, of course; and we wish the traveller something more of a choice than was permitted to us when we were last there, when the wind laid the whole party flat on the summit of the pass, and put all thought of High Street quite out of the question. The account of the weather given by a resident not far off is "It donks and it dozzles; and whiles its a bit siftering: but it don't often mak no girt pel." That is, - it is misty, and drizzles; and it is sometimes showery; but there is not often a great down pour. The wind however is often strong; and the exhaustion from a high wind on high ground is greater than any would believe who has not experienced it.

There is no difficulty in the ascent from Mardale Green; but the traveller indulges in frequent rests, for the sake of looking back upon the singularly-secluded valley, with its winding stream, its faintly-marked track, and its little inn, recognised to the last by the 
sycamores and poplars which overshadow its roof, and rustle before the door. Then he comes to the hollow where lies the tarn, - Small Water. Here he will rest again, sitting among scattered or shelving rocks, and drinking from this pure mountain basin. Arrived at the top, he loses sight of Mardale, and greets Kentmere almost at the same moment. The dale behind is wild as any recess in the district: while before him lies a valley whose grandeur is all at the upper end, and which spreads out and becomes shallower with every mile of its recession from the great mountain cluster.

When he has gone down a mile, he finds that he is travelling on one side of Kentmere Tongue, - the projection which in this and most other valleys, splits the head of the dale into a fork. When he arrives at the chapel, he finds that there is a carriage-road which would lead him forth to Staveley and Kendal. But he is probably intending to go over into Troutbeck: so he turns up to the right, and pursues the broad zigzag track which leads over the Fell, till Troutbeck opens beneath him on the other side. Before beginning the ascent, however, he will note Kentmere Hall, - the birthplace of Bernard Gilpin, in 1517. If familiar with the old description of the district, he will look for Kentmere Tarn, and wonder to see no trace of it. It is drained away; and fertile fields now occupy the place of the swamp, reeds and shallow water which he might have seen but a few years ago. While this tarn existed, the mills at Kendal were very irregularly supplied with water. Now, when the streams are collected in a reservoir, which the traveller sees in coming down 
from the pass of Nanbield, and the intercepting tarn is done away with, the flow of water no longer fails.

The track crosses Applethwaite common into Troutbeck, descending upon the chapel and the bridge in the very depth of that primitive valley, which was one of the first we described (p. 34.) We believe that in the whole circuit there is no scene or object of importance omitted in our detail. 


\section{WEATHER.}

The only remaining consideration is the weather. There is no need to observe that where there are many mountain tops, there must be much rain. The Lake District does receive a high average of rain, as is shown by the following set of observations, published by Dr. Miller of Whitehaven.

FAIL OF RAIN AT SEATHWAITE, BORROWDALE.

1845. 1816. 1847. 1848. 1849. 1850. 1851. 1852. 1853.

Inches 152. 143. 129. 161. 125. 144. 140. 157. 114.

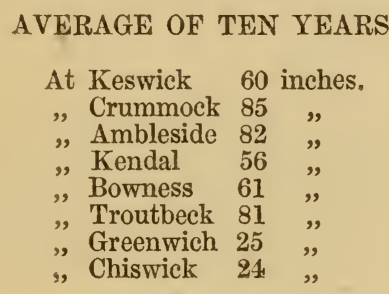

Much of the rich and verdant beauty of the region is derived from its frequent rains; but inexperienced tourists complain bitterly of them. For the guidance of strangers, it may be mentioned that, generally speaking, the worst months of the year in the Lake 
District are November and December for storms; March for spring gales; and July for summer rains. The driest season is usually for a month or more onwards from the middle of May. September and October are often very fine months. Those who come but once, and take only a very cursory view, cannot be too careful in choosing the most favourable season for their trip, though to those who are familiar with the characteristics of this paradise, there is no aspect or accident of earth or sky that has not its charm. 
A TABLE OF THE HEIGHTS OF MOUNTAINS IN THE COUNTIES OF CUMBERLAND, WESTMORLAND, AND LANCASHIRE.

\begin{tabular}{|c|c|c|c|c|}
\hline No. & Names of Mountains. & Counties. & \multicolumn{2}{|c|}{$\begin{array}{l}\text { Height in } \\
\text { Feet above } \\
\text { the } \\
\text { Sea Level. }\end{array}$} \\
\hline $\begin{array}{r}1 \\
2 \\
3 \\
4 \\
5 \\
6 \\
7 \\
8 \\
9 \\
10 \\
11 \\
12 \\
13 \\
14 \\
15 \\
16 \\
17 \\
18 \\
19 \\
20 \\
21 \\
22 \\
23 \\
24 \\
25 \\
26\end{array}$ & 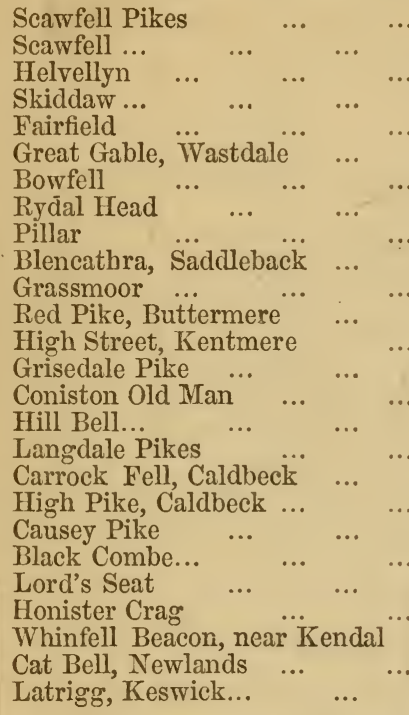 & $\begin{array}{l}\text { Cumberland } \\
\text { Westmorland } \\
\text { Cumberland } \\
\text { Westmorland } \\
\text { Cumberland } \\
\text { ", } \\
\text { Westmorland } \\
\text { Cumberland } \\
\text { Lancashire } \\
\text { Westmorland } \\
\text { Cumberland } \\
\text { ", } \\
\text { ", } \\
\text { ", } \\
\text { Westmorland } \\
\text { Cumberland } \\
\text {," }\end{array}$ & & $\begin{array}{l}3160 \\
3100 \\
3055 \\
3022 \\
2950 \\
2925 \\
2914 \\
2910 \\
2893 \\
2787 \\
2756 \\
2750 \\
2700 \\
2680 \\
2632 \\
2500 \\
2400 \\
2110 \\
2101 \\
2040 \\
1919 \\
1728 \\
1700 \\
1500 \\
1448 \\
1160\end{array}$ \\
\hline \multirow{2}{*}{\multicolumn{4}{|c|}{ 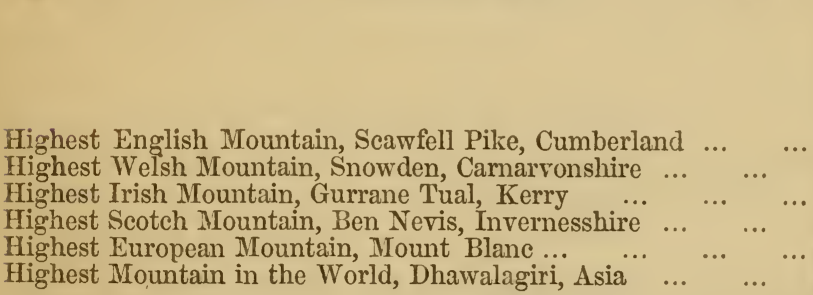 }} & $\begin{array}{l}\text { Height } \\
\text { in } \\
\text { Feet. }\end{array}$ \\
\hline & & & & $\begin{array}{r}3,166 \\
3,571 \\
3,401 \\
4,408 \\
15,781 \\
26,862\end{array}$ \\
\hline
\end{tabular}

\section{PASSES.}

Heights above the Level of the Sea.

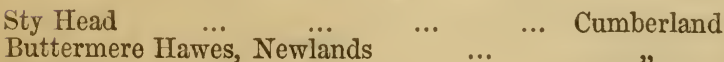

.. 1250

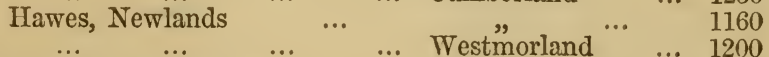

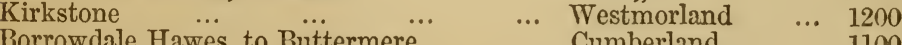

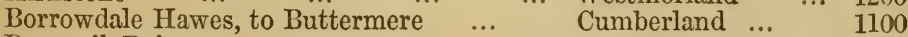

Dunmail Raise ... ... ... $\quad \ldots$ West. \& Cumb. ... 720 
A TABLE OF THE LENGTH, BREADTH, AND DEPTH OF THE LAKES.

\begin{tabular}{|c|c|c|c|c|c|c|}
\hline No. & Names of Lakes. & Coun & $\begin{array}{l}\text { Length } \\
\text { in } \\
\text { Miles. }\end{array}$ & $\begin{array}{c}\text { Extreme } \\
\text { breadth } \\
\text { in } \\
\text { Miles. }\end{array}$ & $\begin{array}{c}\text { Extreme } \\
\text { depth } \\
\text { in Feet. }\end{array}$ & $\begin{array}{l}\text { Height } \\
\text { above } \\
\text { theSea }\end{array}$ \\
\hline $\begin{array}{r}1 \\
2 \\
3 \\
4 \\
5 \\
6 \\
7 \\
8 \\
9 \\
10 \\
11 \\
12 \\
13 \\
14 \\
15 \\
16 \\
17\end{array}$ & 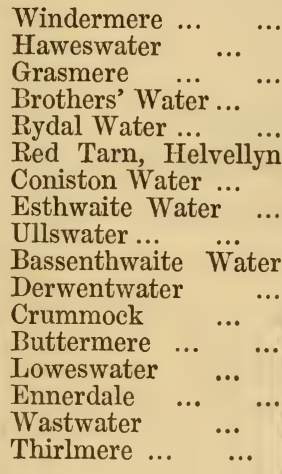 & $\begin{array}{c}\text { Westmorland } \\
\text { ", } \\
\text { ", } \\
\text { Lancashire } \\
\text { Cumb"rland } \\
\text { ", } \\
\text { ", } \\
\text { ", } \\
\text { ", } \\
\text { ", }\end{array}$ & $\begin{array}{l}10 \\
3 \\
1 \frac{1}{4} \\
0 \frac{3}{4} \\
0 \frac{1}{2} \\
6 \\
6 \\
2 \\
9 \\
4 \\
3 \\
3 \\
1 \frac{1}{4} \\
1 \\
2 \frac{1}{2} \\
3 \\
2 \frac{3}{4}\end{array}$ & $\begin{array}{l}1 \\
\frac{1}{2} \\
\frac{1}{3} \\
\frac{1}{3} \\
\frac{1}{3} \\
\frac{1}{\frac{1}{2}} \\
\frac{1}{2} \\
1 \\
1 \\
1 \frac{1}{2} \\
\frac{3}{4} \\
\frac{3}{4} \\
\frac{1}{2} \\
\frac{1}{2} \\
\frac{1}{2} \\
\frac{1}{2}\end{array}$ & $\begin{array}{r}240 \\
180 \\
72 \\
54 \\
\overline{160} \\
80 \\
210 \\
68 \\
72 \\
132 \\
90 \\
60 \\
80 \\
270 \\
108\end{array}$ & $\begin{array}{r}116 \\
443 \\
180 \\
- \\
156 \\
2400 \\
105 \\
198 \\
380 \\
210 \\
228 \\
210 \\
247 \\
- \\
- \\
160 \\
473\end{array}$ \\
\hline
\end{tabular}

WATERFALLS.

\begin{tabular}{|c|c|c|c|}
\hline No. & Names and Situations of Falls. & Counties. & $\begin{array}{c}\text { Feet } \\
\text { in } \\
\text { Height. }\end{array}$ \\
\hline $\begin{array}{r}1 \\
2 \\
3 \\
4 \\
5 \\
6 \\
7 \\
8 \\
9 \\
10 \\
11\end{array}$ & 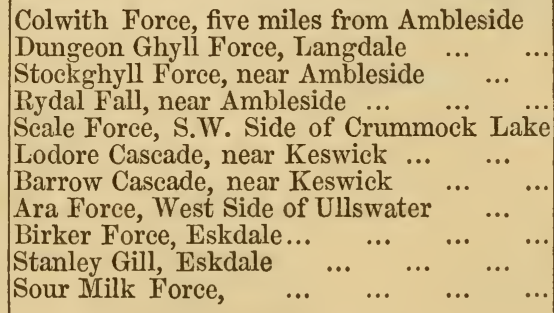 & $\begin{array}{c}\text { Westmorland } \\
\text { Cumberland } \\
", \\
" \\
" \\
" \\
"\end{array}$ & $\begin{array}{r}90 \\
90 \\
70 \\
70 \\
160 \\
150 \\
122 \\
80 \\
65 \\
62 \\
60\end{array}$ \\
\hline
\end{tabular}




\section{FLOWERING PLANTS, FERNS, AND MOSSES.}

WINDERMERE AND ITS NEIGHBOURHOOD.

The banks of Windermere afford many objects of interest to the lover of British wild flowers; so numerous and various, indeed, are the more or less rare plants to be found in the lake itself, - in the mountain tarns, streams, woods and bogs, and on the fells and heath, that it is difficult to give a satisfactory account of them in the space of a short chapter. A general description of the Flora of the district may, however, be of some use to the tourist who, in passing through the country, wishes to secure anything which may be worthy of a place in his herbarium or garden. The writer proposes to enumerate the least common plants which have been found within about three miles of the lake, occasionally noticing objects of peculiar interest which are found at a greater distance.

Of the order Ranunculacæe, Thalictrum flavum is not uncommon about the margin of the lake; T. minus is also found; the beautiful globe-flower Trollius europœus is abundant in various situations; Helleborus virdis occurs in two situations near Windermere terminus, and $H$. fotidus grows near the 
road between Bowness and Kendal : it is very probable that both these are introduced; Aquilegia vulgaris is found in numerous places.

Of Nymphœaceœ, Nymphœa alba and Nuphar lutea are frequent in the lake and many of the mountain tarns.

Of Papaveraceæ, Meconopsis cambrica is not uncommon, and in some places, such as near the Ferry Inn and other parts of Furness Fells, and in Troutbeck it is abundant; Chelidonium majus is common.

Of Fumariaceœ, Corydalis claviculata is not uncommon in heathy places.

Of Cruciferœ, Lepidium Smithii is abundant; L. draba grows near Newby Bridge; Arabis hirsuta is found on Whitbarrow; Cochlearia officinalis on Kirkstone. Helianthemum canum, of the order Cistacæ, occurs in Witherslack.

Of Droseraceæ, Drosera rotundifolia is abundant, and D. longifolia is rare.

Of Caryophyllaceæ, Stellaria nemorum is found in some wet woods and ghylls; Silene acaulis grows on Fairfield.

Of Malvaceæ, Malva moschata and sylvestris are frequent in various places.

Of Hypericaceæ, Hypericum androsœmum is not uncommon on wooded fellsides, generally near rivulets; H. quadrangulum and humifusum are common, and $\mathrm{H}$. hirsutum is plentiful on Whitbarrow.

Of Geraniaiex, Geranium sylvatium is not uncommon; G. lucidum is frequent; G. sanguineum and pratense are abundant on Whitbarrow. 
Of Balsaminaceæ, Impatiens noli me tangere is plentiful on Furness Fells, near the Ferry Inn, at Millerground, Gill Head, and many other places.

Of Rhamnaceæ, Rhamnus catharticus and frangula are found on the islands of Windermere.

Of Leguminifereæ, Genista tinctoria is very abundant and beautiful in heathy places; Hippocrepis comosa is found at Grange.

Of Rosaceæ, Prunus padus is common; Spiræa salicifolia grows near the Ferry Inn, but this is doubtless introduced, as this plant is now found to be nowhere indigeneous in Great Britain; Rubus suberectus is found in roods and sometimes on open mountain sides; $R$. saxatilis occurs in a few places; $R$. idœus rhamnifolius, lucostachys and rudis are the most common species of Rubus here; $R$. chamæmorus grows in Long Sleddale; we have seen Rosa spinosissima in a few places; $R$. villosa is very common.

Of Haloragiaceæ, Myriophyllum spicatum and verticillatum abound in the lake.

Of Grossulariaceæ, Ribes rubrum and grossulara are plentiful in the woods.

Of Crassulaceæ, Sedum telephium and anglicum are very common; S. Rhodiola grows on Fairfield; and Cotyledon unibilicus is found in many places.

Of Saxifragaceæ, Saxifraga aizoides stellaris, and hypnoides are found on the mountain tops: we have not seen S. oppositifolia nearer than Helvellyn; S. platypetala grows on the heights of Fairfield; Chrysoplenium alternifolium is also found by some rivulets; Parnassia palustris is very abundant. 
Of Rubiaceæ, Galium boreale grows on the islands of Windermere and Asperula cynenchica is found on Whitbarrow.

Of Umbelliferæ, Sium angustifolium is common in the streams, and Myrrhis odorata is by no means rare in old orchards and elsewhere.

Of Compositæ, Apargia hispida is common and very handsome; Sonchus palustris occurs in some marshy places; Crepis paludosa is frequent in wet woods; Hieracium alpinum is found on Langdale Pikes; $\mathrm{H}$. lawsoni, on Kirkstone Pass; H. inuloides, in mountain rills; $H$. sylvaticum and boreale are common; but we are not able to give a list of all the mountain species of Hawkweed which may be found in the district; the lower range of fells, near the lake, are not likely to produce any rare species, but the higher series, Fairfield, High Street, Hill Bell, \&c., would be very likely to repay a more careful search than has hitherto been made. Serratula tinctoria is plentiful on the shores of the lake; Carduus heterophyllus grows in Troutbeck, Carlina vulgaris on Whitbarrow ; Centaurea nigrescens is not unfrequent on dry banks; Bidens cernna is found in Crosthwaite; Eupatorium cannabinum is everywhere common; Gnaphalium dioicum and sylvaticum are abundant, the former on mountain heaths, the latter in woods; Petastites vulgaris is found in several places; Senecio saracenicus grows near Newby Bridge, and in some old orchards, but it is probably not indigenous; Inula conyza is abundant on the Whitbarrow Fells. Of Campanulaceæ, Campanula latifolia is not unfrequent 
in woody places; Jasione montana everywhere abundant, and the larger form, which has been thought by some to be a distinct species, is often seen in the meadows ; Lobelia dortmanna grows in shallow water, in almost every part of the lake.

Of Ericaceæ, Vacinum myrtillus is found in nearly every wood; and V. oxycoccus in a few places; V. vitis-idea on Langdale Pikes ; Pyrola minor in Stockghyll.

Of Jasminaceæ, Ligustrum vulgare grows wild in the mountain woods.

Of Gentianaccæ, Menyanthes trifoliata is not uncommon in the bogs; Polemonium cæruleum is found in Graithwaite woods.

Of Scrophularianæ, Digitalis purpurea is everywhere most abundant and beautiful, ornamenting every hill and dell with its splendid spikes of purple flowers Verbena officinalis may be gathered on Whitbarrow. Of Orobanchaceæ, Lathræa squamaria grows on Wansfell.

Of Lamiaceæ, Lycopus europœus is found in a few places, as is also Calamintha clinopodium; Mentha piperita grows on Whitbarrow; M. sativa is not uncommon throughout the district; Scutellaria minor occurs in some of the bogs.

Of Boraginaceæ, Symphytum officinale is not uncommon.

Of Pinguiculaceæ, Pinguicula vulgaris is very frequent in damp places; Utricularia vulgaris is also found. Of Primulaceœ, Primula farinacea may be found in many moist meadows : it is abundant on Wansfell, 
and will be seen when ascending the mountain by Stockghyll; Lysimachia vulgaris, nummularia and nemorum are common, the two former by the side of the lake.

Of Plantaginaceæ, Plantago media is common near Kendal and on Whitbarrow; Littorella lacustris covers the margins and bottom of the lake, with a perennial verdure.

Of Polygonaceæ, Polygonum bistorta is common and very ornamental in low meadows; Oxyria reniformis is found in Longsleddale, and elsewhere.

Of Thynelaceæ, Daphne laureola and mezereum have been found in Rayrigg and Graythwaite woods.

Of Empetracex, Empetrum nigrum grows on the higher fells.

Of Amentiferæ, Carpinus betulus is not uncommon, but probably not indigenous; Salix pentandra occurs in many places; S. fragilis alba, viminalis, caprea and aurita are common; but we are not sufficiently acquainted with this genus to mention all the species around here.

Of Orchidacer, Listera ovata is common, and L. cordata is found on Helvellyn: L. nidusavis is rare; Gymnadenia conopsea and Habenara bifolia are very common; Cypripedium calceolus has been found on Whitbarrow ; and Epipactis latifolia, palustris and ensifolia also grows there.

Of Amaryllidaceæ, Narcissus pseudo-narcissus is most abundant, and in early spring makes many a bank and woody glen yellow with its numerous flowers.

Of Liliaceœ, Allium carinatum is found in one locality ; 
H. ursinum is very common; H. schœnoprasum may be found on Cartmel Fell; Convallaria majalis grows on some of the islands, but is becoming scarce from too frequent depredations ; in Rauncey woods, about three miles below Newby Bridge, this plant is most abundant and fine, covering some acres of ground; here also may be found the Fly orchis ; C. multiflora abounds in Graythwaite woods, about two miles north of Newby Bridge.

Of Trilliaceœ, Paris quadrifolia is found in many of the shady woods.

Of Alismacee, Alisma plantago and ranunculoides are plentiful in the lake.

Of Fluviales, Potamogeton prolongus is found in many parts of Windermere; P. perfoliatus and heterophyllus are very common.

Of Juncacee, Juncus glancus grows on Whitbarrow, and $J$. triglumis on Fairfield.

Of Cyperaceœ, Eriophorum vaginatum is frequent in mountain bogs ; Carex dioica, ovalis, riparia, pulicaris, curta, remota, stricta, prœcox, vesicaria, and ampullacea are common; C. lœevigata and sylvatica are found in some places.

Of Gramina, Avena pubescens and flavescens, are common; Festuca ovina var, vivipara is found; Bromus giganteus is very frequent; B. asper and Sesleria cærulea grow on Whitbarrow; Triticum caninum may be seen in many places; and Melica nutans is found in some moist woods.

Of the Ferns -

Caterach officinarum, occurs on some walls, but is 
abundant and indigenous on Whitbarrow.

Polypodium vulgare grows very luxuriantly, and in some shaded situations with a south aspect, assumes a form resembling $\mathrm{P}$. cambricum, but does not retain its peculiar character under cultivation; the variety serratum, also grows in similar situations : it is very handsome.

Polypodium phegopteris is more than usually common in this district, and may be found in many woods and often by the road sides; P. dryopteris is not quite so frequent, but by no means uncommon in similar situations : it is very abundant in the woods of Furness Fells.

Polypodium calcareum is common on Whitbarrow.

Allosorus crispus is not rare in stone walls or rocks, and among loose stones, generally in high situations.

Cystopteris fragilis is very fine in some situations, but is not abundant here; a form is found which somewhat resembles C. regia.

Polystichum lonchitis has been found; P. aculeatum is common by rivulets, through mountain woods and coppices, and its varieties lobatum and lonchitoides; $\mathrm{P}$. angulare is less common, but may be found in many warm shady ghylls and groves growing very luxuriantly.

Lastrea oreopteris is very common; the different forms of L. dilatata abound; the variety called by $\mathrm{Mr}$. Newman L. collina, is not rare; L. Spinu losa is to be found in many wet woods; also in some open bogs, and a few roots of a form of this species closely resembling, if not identical with $\mathrm{L}$. crista, have been 
found; L. recurva occurs in a few places. Athyrium felix-femina var rhoticum is not uncommon. Asplenium viride is found on some of the mountain screes, and is very abundant on Whitbarrow; $\mathrm{A}$. Trichomanes, Adiantumnigrum and ruta-muria are common, and A. marinum is found on Meathop, near Witherslack.

Scolopendrium vulgare grows very fine in some sheltered situations.

Blechnum boreale is common everywhere.

Hymenophyllnm Wilsoni is found in many dark fissures in the rocks in high wooded fells, generally near a stream.

Osmunda regalis is common and fine.

Botrychium lunaria is pretty frequent on high mountain heaths.

Ophioglosum vulgatum is very scarce.

In giving an account of the ferns of Windermere, the important discovery of Woodsia Ilvensis in Westmorland, although not in the immediate neighbourhood of Windermere, ought to be mentioned. This rare fern was found by Mr. Huddart, the nurseryman of Waterloo Gardens immediately opposite Bowness, who has some roots of it and of almost all the British ferns in his possession.

All the British club mosses are found near Windermere.

Lycopodium clavatum grows on most of the higher fells; L. annotium has been found in Langdale: L. inundatum is not unfrequent on the margins of mountain tarns; L. alpinum grows on many heathy fell- 
sides ; L. selago in similar situations ; and L. selaginoides is common in rivulets in high situations.

Isoetes laustris is abundant in all parts of the lake, but rather difficult to find, because it is nearly always in deep water.

Equisetum palustre var, polystachyon is the only uncommon Horsetail which has hitherto been found here.

The common Mosses are abundant here, and some species may be found which are very scarce in Great Britain, and are only seen in some alpine or sub-alpine districts. The Muscologist will be delighted with the general appearance of this tribe of plants, their luxuriance in some situations is truly wonderful. Among the most rare may be mentioned

Zygodon mangestii, in crevices of rocks, without fruit, on Kirkstone.

Gymnostomum rupestre, on wet rocks Helvellyn; G. Griffithanum on Red Screes, Wrynose and Fairfield. Dyphisicum foliosum on rocks and crevices of rocks, Rydal Park.

Weissia denticulata on rocks, Grasmere Fells; W. tenuirostris, in Troutbeck and at Cook's House, near Windermere.

Grimmia spiralis and torta below Red Screes, Kirkstone, but not in fruit.

Orthotrichum rupincola on walls by Mardale and Haweswater; O. aristatum on trees in Rydal Park and elsewhere.

Bryum julaceum in mountain rills, fruiting abundantly in Kirkstone Pass and Wythburn beck; B. albicans 
in mountain rills ; B. Ludwigii on wet rocks, Glaramara, not in fruit; B. zierii in crevices of rocks and on the ground, Red Screes, Rydal Park and elsewhere; B. Alpinum common, on the mountains usually barren; B. uliginosum in a branch of the Wythburn beck, High Raise; B. accuminatum on the eastern precipiece of Fairfield, between the summit and Rydal Head; B. mnioides on Helvellyn.

Hypnum flagellare in rocky streams, Stockghyll, \&c.; H. crista castrensis on banks above Troutbeck Park, by the road over Kirkstone, Dove Craig, Fairfield, Mardale, and Hawes Water.

Of those mosses which are rare, except in mountain districts, may be mentioned as occuring abundantly here,

Anictangium ciliatum, common on walls and rocks.

Anomodon curtipendulum very common, in some situations bearing fruit abundantly.

Bartramia pomiformis and halleriana are common; B. arcuata is found here, but rare in fruit.

Hypnum brevirostre is very abundant in woods; $\mathrm{H}$. undulatum is very fine, and bears fruit in some high woods, generally near waterfalls.

Nechera crispa is a great ornament to rather wet rocks. Polytrichum alpinum and urnigerum are common, as are also

Trichostomum acciculare, canescens, fasciculare, lanuginosum and polyphyllum. 
The Lake District, and the margin of comparatively level land extending to the Cumberland shore, affords such a scope for the natural production of plants as few of the English counties possess.

The great diversity of altitude,* and consequent variety of climate; the numerous and extreme changes of mineral and vegetable soils; the complete circuit of aspect occasioned by the multiplicity and varied character of its hills and dales; the perfect exposure to the sea-breezes in some parts, and the exclusion from them in others; and the very different degrees of moisture to which the district is subject, varying from nearly 160 inchest of rain-fall per annum in one or two of the mountain vales, to only about 24 inches $\$$ in some of the lowland levels, accommodate the growth of a great variety of the British flora - the product of almost every locality between extreme anglo-alpine and the verge of the sea.

It is true that agricultural enterprise is quietly and gradualy, but surely, diminishing the numbers of the species; and perhaps the monopolising avarice of pro-

* Scawfell Pike, the highest land in the county, is 3160 feet above the level of the sea. - Mr. OTLEY.

+ At Borrowdale per Dr. Miller.

‡ Harraby, near Carlisle. 
fessed collectors * may aid the destructive progress not a little, even to the total extermination of some plants. Still, such a range of variety is found between the littoral and alpine extremes of West Cumberland as may fairly gratify the wishes of the true botanist.

It must be understood that these remarks, and the following list of plants and localities, relate almost exclusively to the Cumberland limits of the district; and that the botanical resources of that district have been tolerably well explored by the writer for a lengthened period. His endeavours have also been aided by several friends (whose names are quoted); but it is still possible that some of the floral treasures may have been overlooked, or may yet remain undiscovered. Those will be but few, and of course valuable when their localities become known.

Many common plants are omitted from the list, under the impression that what is open to every one's eye needs no record; and numerous localities are also left out as redundant.

Perhaps no district, of the same limited extent, furnishes a more numerous assemblage of Cryptogamic plants; - that least explored, but very beautiful department; and which may be not inappropriately called winter-botany.

A great proportion of the singular system of bloom-

* Only a year or two ago, one of this class being told of the habitat of the rare Grammitis Ceterach, went and picked out of the wall in which it grew, with the point of a knife, every plant! Fortunately, some seeds had been deposited, and they have restorerthe treasure. 
ing peculiar to this class is developed at the season when most other vegetation is at rest, and therefore uninteresting; here then may the zealous botanical tourist still continue his study with as much ardour as in the summer; and derive pleasure and edification from the contemplation of the various gay or modest tints of these minute works of the Creator, when the casual observer will find nothing to attract his attention from the general dreariness of a wintry landscape.

Those who would acquaint themselves with the mosses and linchens of the lake and mountain district, will need some degree of perseverance and surefootedness in exploring the dark ravines and cavernous fissures of the moist and slippery rocks, and of the gloomy woods where these delight to grow; and will meet with perhaps the greatest variety, and those in the highest perfection, where the sun shines seldomest and the rain falls oftenest upon them. And it should be remembered that no satisfactory progress can be made in collecting and distinguishing the cryptogamia when the plants are shrivelled by drought.

No little energy will be requisite, also, to hunt out the linchens - some of which are found inhabiting almost every rood of undisturbed ground from the verge of the ocean, to the storm-beaten summits of the highest mountains. And last, not least, very considerable patience is necessary to duly investigate and decipher the microscopic stamp of family, so minutely, but distinctly impressed upon every specific member of the whole tribe of both mosses and linchens; and a great 
many are too small to be accurately determined by the naked eye. But to the enthusiast in botany, the pleasing excitement of the pursuit, and the gratification of the capture, well reward the fatigues of the search.

The subjoined list follows the order and nomenclature of Macgillivray's hand-book, to save the time required to adapt it to the more recent alterations.

Salicornia herbacea, Ravenglass, Workington; S. procumbens, Workington north shore.

Hippurus vulgaris, Dub mill.

Zostera marina, Bootle shore, brought up by the tide.

Chara flexilis, Whillimoor; C. aspera, Harras Moor.

Callitriche verna, Whinlatter; C. pedunculata, Ennerdale.

Circæa alpina, Barrow side; C. lutetiana, Keswick. Veronica Anagallis, St. Bees and Ellen; V. scutellata, Ullock Moss ; V. montana, Walla Crag; V. hederifolia, Distington, Workington.

Pinguicula vulgaris, common in bogs.

Utricularia minor, Shoulthwaite Moss, Eskmeals.

Lycopus europœus, Ribton Hall. (Mr. Tweddle.)

Lemna minor, ponds in Whillimoor.

Fedia olitoria, Moresby Hall; F. dentata, Frizington.

Scirpus lacustris, Loweswater Lake; S. setaceous,

Ennerdale; S. maritimus, Workington, (Mr. Tweddle); S. sylvaticus, banks of the Marron.

Eleocharis cœspitosus, Murton Moss; E. pauciflorus, Murton Moss ; E. fluitans, Cogra Moss in Lamplugh ; E. palustris, Loweswater Lake ; E. multicaulis, Ennerdale Lake; E. acicularis, Egremont.

Eriophorum vaginatum, common in bogs; E. angus- 
tifolium, Calder Ghylis and Edge Tarn; polystachion, Brigham Moss.

Catabrosa aquatica, Coulderton Shore - scarce.

Arundo Phragmites, River Derwent ; A. calamagrostis, River Derwent; A. arenaria, sea shore, Coulderton. Rotbollia incurvata, Skate Dubs, Workington. (Mr. Tweddle.)

Hordeum murinum, Flimby ; H. maritinum, Coulderton. Triticum juncum, Braystones.

Asperula odorata, Lodore Fall.

Galium cruciatum, Lamplugh, \&c.; G. palustre, Brackenthwaite, Lodore; G. saxatile, St. John's vale; G. Mollugo, Crofton Hall, Pardshaw, \&c.; G. verum, Tallantire, Lamplugh, Lodore; G. boreale, Derwent Lake shores, and river Irthing.

Plantago major, Arlecdon; P. media, Arlecdon and Egremont; P. maritima, Moota, Flimby and Gillerthwaite; P. Coronopus, shore at Flimby, Ravenglass, \&c.

Parietaria officinalis, Torpenhow Church.

Ruppia maritima, Cloffocks (Mr. Tweddle.)

Alchemilla alpina, Borrowdale Hause and Helvellyn.

Radiola Millegrana, var. maritima, Ehenside (Mr. G.

Chambers.)

Lithospermum officinale, Mosser; L. arvense, Stanger;

L. maritimum, Bootle Shore and Workington:

Anchusa sempervirens; Gosforth, Sandwith.

Cynoglossum officinale, Flimby.

Lycopsis arvensis, St. Bees.

Primula elatior, Seaton, Lamplugh; P. veris, (red variety), Egremont Clints ; P. farinosa, Wanthwaite Mill, Caldbeck, and a dark red variety near Ireby-low. 
Lysimachia vulgaris, Keswick, Ennerdale, Lorton; L. nemorum, Castlehead Wood and Lamplugh.

Anagallis cerulea, Hensingham 'Toll-bar.

Convolvulus arvensis, Fitz Toll-bar (Mr. Tweddle.); C.

Soldanella, Shore at Coulderton and Harrington.

Jasione montana, common.

Lobelia Dortmanna, nearly all the lakes.

Viola lutea, Brigham.

Hyoscyamus niger, Cockermouth, Flimby, Harrington. Atropa Belladonna, once plentiful around Egremont

Castle, but now only retained in a few gardens there. Solanum Dulcamara, St. John's vale, Setmurthy.

Erythroa Centaurium, Bootle, Distington, and a pure white variety in Loweswater.

Samolus Valerandi, Coulderton Shore.

Lonicera Caprifolium, Lorton Hall (Mr. Tweddle) ; L.

Xylosteum, Workington Park (Mr. Tweddle.)

Rhamnus frangula, Ullock Moss (Mr. Otley).

Eixonymus europæus, Lodore Woods.

Ribes rubrum, banks of the Derwent; R. nigrum, ditto ;

R. Grossularia, limestone rocks at Sunderland.

Glaux maritima, Ravenglass, St. Bees.

Salsola Kali, Coulderton; S. fruticosa, Ravenglass.

Gentiana Amorella, Tallantire Hill ; G. campestris, Tal-

lantire Hill, Workington Warren; G. verna, till lately

on Egremont Green, perhaps now extinct.

Eryngium maritimum, common along the sea shores.

Hydrocotyle vulgaris, common in bogs.

Sanicula europœa, Wythop Woods.

Torilis nodosa, Bewaldeth - scarce.

Anthriscus vulgaris, Workington Bridge. 
Chœrophyllum sylvestre, Gillfoot and Whicham. Daucus carota, Ravenglass.

Sium angustifolium, Drigg Haws ; S. nodiflorum, Gill near St. Bees ; S. repens, Naddale ; S. verticillatum, Naddale S. inundatum, Loweswater Lake.

Crithmum maritimum, St. Bees rocks. Apium graveolens, Workington Marsh. Imperatoria Ostruthium, Gilsland Woods.

Meum athamanticum, Fell End in Ennerdale (Dr. Lawson.)

Pimpinella dioica, Tallantire Hill.

Cnidium Silaus, Seaton, Schoose Farm.

Sambucus Ebulus, Brackenthwaite, Scalelands.

Parnassia palustris, meadow and bogs, not rare.

Statice Armeria, Scawfell and sea shores; S. Limonium, sea shore near Bootle, \&c.; S. spathulata, St. Bees Heads (Mr. Robson.)

Drosera rotundifolia, common in bogs ; D. longifolia, Borrowdale (Mr. Tweddle); D. anglica Helvellyn (Mr. J. Flintoft.)

Narcissus Pseudo-Narcissus, Duddon Woods.

Allium arenarium, banks of the Derwent (Mr. Tweddle);

A. vineale, Bearpot near Workington; A. ursinum, Salter Hall.

Juncus filiformis, Crummock and Derwent Lakes.; J. J. cœnosus, Millom Marsh; J. uliginosus, Workingington (Mr. Tweddle); J. triglumis, Helvellyn (Mr. J. Flintoft.)

Luzula pilosa, common in woods; L. Fosteri, woods between the mountains and the sea; L. sylvatica, banks of the Marron; L. campestris, common on 
bare heaths; L. congesta, common on bare heaths. Peplis Portula, Harras Moor, Kinniside long Moor, Calder Gills.

Oxyria reniformis, Ashness Gill.

Triglochin palustre, common at the edges of bogs ; $\mathrm{T}$. maritimum, Cloffocks.

Alisma plantago, Keswick Cass ; A. ranunculoides, Eskmeals.

Epilobium hirsutum, river Eden and its tributaries.

Vaccinium Myrtillis, common on woods and on mountains; V. uliginosum, Wardrew Moss, Moorside Parks; V. vitis idœa, Skiddaw, Iron Crag, Swinside Fell, \&c.; V. oxycoccus, common in bogs.

Acer campestre, Mirehouse Woods.

Polygonum Bistorta, in meadows, and cultivated as a pot herb ; P. viviparum, Helvellyn (Mr. J. Flintoft); P. aviculare, Lodore road; P. convolvulus, Bassenthwaite; P. amphibium, Dearham; P. Hydropiper, Lodore.

Paris quadrifolia, woods in Lamplugh. Andromeda polifolia, Moresby.

Arbutus uva-ursi, Bootle Fell (Rev. Isaac Hodgson), Brackenthwaite (Mr. Wilson Robinson).

Pyrola rotundifolia, Walla Crag; P. media, Kirklinton Moors; P. secunda, Helvellyn.

Chrysosplenium oppositifolium, common in wet woods ;

C. alternifolium, Portinscale Bridge.

Saxifraga stellaris, Helvellyn, Iron Crag, \&c. ; S. nivalis, Legberthwaite Gills; S. oppositifolia, Borrowdale, Wastwater Screes (Mr. Robson) ; S. aizoides, Barrow Side, Grassmoor; S. granulata, Harrington 
Church; S. tridactylites, Moota and Whicham; S. hypnoides, Armboth Fell, Shoulthwaite.

Scleranthus annuus, St. Bees, Knockmurton, Eskdale. Saponaria officinalis, Derwent Side, near Workington (Mr. Tweddle).

Silene inflata, Clifton, Dean Scales, \&c.; S. maritima, Eskmeals, Brackenthwaite, Grange ; S. nutans, Dean, Moorland Close; S. acaulis, Borrowdale. Stellaria nemorum, Burdoswald, Moorside Hall. Arenaria peploides, Seaton, Flimby ; A. serpyllifolia, Pardshaw Hall, Cockermouth.

Cotyledon umbilicus, Ehenside, Gosforth.

Sedum Telephium, Castlehead, Millom; S. album, Braystones ; S. villosum, Mosedale; S. anglicum, Beckcote; S. acre, St. John's; S. sexangulare, Hunday Gate. Lychnis alpina, Brackenthwaite Fells.

Cerastium tetrandum, Cockermouth; C. alpinum, Helvellyn (Mr. J. Flintoft).

Spergula nodosa, Lilly Hall (Mr. Tweddle).

Lythrum Salicaria, Ennerdale, Newlands, Beckermont. Agrimonia Eupatoria, Lamplugh churchyard; A. eupatoria var odorata, Lorton (Mr. W. Robinson).

Reseda Luteola, Flimby, Eaglesfield, Workington.

Rosa rubella, Thirlwall ; R. spinosissima, plentiful on the coast at Seascale, \&c.; R. Hibernica, Brackenthwaite; R. Sabini, Derwent Bay ; R. villosa, Gilsland; R. tomentosa, Lamplugh ; R. canina, Loweswater; R. arvensis, Whillimoor.

Rubus idæus, common; R. cœsius, Tallantire ; R. corylifolius, Arlecdon; R. fruticosus, very common; R. rhamnifolius, Ulpha, Lowca, Flimby; R. glandulo- 
sus, Pardshaw; R. suberectus, Moorside Hall; R. saxatilis, Gilsland; R. Chamœmorus, Styx moss.

Comarum palustre, common in meadow ditches.

Chelidonium majus, Kirkland, St. Bees.

Glaucium luteum, Flimby, Coulderton, Bootle shores.

Meconopsis Cambricum, Naddale.

Nymphœa alba, Mockerkin Tarn.

Nuphar lutea, Mockerkin Tarn, Bassenthwaite Lake, Wormanby Lough.

Aquilegia vulgaris, shore of Bassenthwaite Lake, Dovenby.

Stratiotes aloides, Ennerdale Lake (Mr. Robson.)

Thalictrum minus, Side woods in Ennerdale; T. majus,

Derwent Lake shores; T. alpinum, Great End, Scawfell (Mr. Robson.)

Ranunculus Lingua, Naddale beck, Wasdale and Eskdale (Mr. Robson) ; R. Flammula, common in cold soils ; R. auricomus, Pardshaw ; R. hirsuta, Drigg, Workington Marsh; R. hederaceus, Lamplugh Hall, Pardshaw; R. aquatilis, St. Bees Moor.

Trollius europœus, Arlecdon Churchyard.

Helleborus viridis, Duddon Woods and Plumbland (Mr.

Tweddle.)

Mentha rotundifolia; M. piperita; M. hirsuta; M. gentilis, near Sykes in Naddale, in ditch sides. Glechoma hederacea, Barrow Side. Galeobdolon luteum, Crosedale. Ballota nigra, Workington (Mr. Tweddle.) Stachys annua, Lingbank, in Gosforth. Leonurus Cardiaca, Workington Row (Mr. Tweddle.) Clinipodium vulgare, Mockerkin, Papcastle. 
Thymus Acinos, Low Lingbank, Nethertown, (Mr. Chambers) ; T. Calamintha, Calva Hall, Scutellaria galericulata, Dub Beck, Braithwaite Beck; S. minor, Ladstocks in Thornthwaite.

Rhinanthus crista-galli var. majus, Chapel Bank, St. Helens.

Melampyrum pratense, common in old woods.

Camelina sativa, Workington Mill field (1848 Mr. Tweddle.)

Teesdalia nudicaulis, St. John's, Raven Crag, Thief Gill in Dean.

Cochlearia officinalis, Coulderton Shore, Fleswick Bay ; C. anglica, Workington Shore; C. grœnlandica var. alpina, rills on Helvellyn.

Senebiera coronopus, Seaton (Mr. Tweddle.)

Crambe maritima, Coulderton Shore.

Cakile maritima, Seaton Shore.

Cardamine hirsuta, elevated situations in Whillimoor;

C. pratensis, common, sometimes double; C. amare, Moorside Woods, Bearpot (Mr. Tweddle.)

Arabis stricta, Lamplugh Hall, Pardshaw Hall; A. hirsuta, Shoulthwaite, Moota.

Turritis glabra, Stainburn (Mr. Tweddle.)

Chieranthus fruticulosus, walls of Scaleby Castle.

Brassica Monensis, Flimby and St. Bees Shore.

Erodium cicutarium, Gosforth; E. maritimum, St. Bees. Geranium sylvaticum, St. John's vale; G. pratense, Lamplugh; G. rotundifolium, Yeorton Hall; G. pusillum, Etterby Scar; G. Robertianum, St. John's vale; G. lucidum, Lodore Bridge: G. columbinum, Cockermouth Fitz (Mr. Tweddle); G. sanguineum, St. Bees Shores. 
Genista scoparia, Bridekirk ; G. tinctoria, Seaton, Tallantire, Arlecdon; G. anglica, Drigg, Bootle.

Ulex nana, Gosforth, Lamplugh Fells.

Anthyllis vulneraria, Maryport Railway.

Pisum maritimum, Harrington Rocks.

Lathyrus Nissolia, Irton, in sand.

Vicia sylvatica, Clifton Woods, Parton; V. angustifolia, Stainburn, Santon.

Ornithopus perpusillus, Irton Church, St. Bees Moor. Trifolium officinale, Workington Station, Etterby Scar ; T. ornithopodioides, Workington Warren (Mr. Tweddle); T. arvense, Flimby; T. striatum, St. Bees (Mr. Chambers); T. procumbens, Drigg; T. filiforme, Gosforth.

Hypericum calycinum, Irton; H. quadrangulum, Clifton; H. perforatum, Keswick Woods ; H. humifusum, Lodore Fall ; H. hirsutum, Camerton, Clifton ; H. pulchrum, Castlehead Woods ; H. elodes, Birker Moor, Aitcha Moss.

Tragopogon pratensis, Bransty, Schoose.

Prenanthes muralis, Borrowdale, Ulpha.

Apargia autumnalis, Ennerdale.

Hieracium subaudum, Ennerdale, in side woods; $\mathrm{H}$. umbellatum, Kirkland How.

Crepis tectorum, Woodcock Nook, near Egremont (Mr. Chambers.)

Serratula tinctoria, Embleton, Lorton.

Saussuria alpina, Helvellyn (Mr. J. Flintoft.)

Carduus acanthoides, Carlisle Castle.

Cnicus heterophyllus, Armboth, Watendlath; C. acaulis, Barrow Side, Hardknot. 
Carlina vulgaris, Ennerdale.

Bidens cernua, Braithwaite, Cloffocks (Mr. Tweddle); B. tripartita, Keswick Cass, Bootle.

Gnaphalium divicum, Helvellyn; G. germinicum, Drigg; G. rectum, base of Helvellyn; G. uliginosum, Arlecdon; G. minimum, Fieldhead in Eskdale; G. gallicum, Drigg, Gosforth.

Senecio tenuifolius, Little Broughton; S. saracenicus, Moresby, Sebergham.

Aster Tripolium, Eskholm, Holborn Hill.

Solidago Virgaurea, Scalehill.

Inula Helenium, Mosser ; I. dysenterica, St. Bees Heads. Pyrethrum Parthenium, Nether Hall.

Matricaria chamomilla, Sylcroft.

Anthemis maritima, Coulderton.

Centaurea Scabiosa, Eaglesfield.

Orchis bifolia, Whillimoor; O. pyramidalis, common;

O. mascula, common, Dovenby, \&c.; O. albida, Little Broughton (Mr. W. Robinson) ; O. viridis, Murton Moss.

Gymnadenia conopsea, Wanthwaite, St. John's, Moota. Listera ovata, common; L. cordata, Castlerigg Fell, Melbreak; L. nidus-avis, Flimby Wood, Wood Hall. Epipactis latifolia, Dean Scales, Bridgefoot.

Euphorbia Peplus, Egremont, Bootle Station; E. exigua, Bridgefoot; E. helioscopia, Gosforth; E. portlandica, Braystones (Mr. Chambers) and Drigg shores ; E. paralia, Haverigg and Harrington shores. Typha latifolia, Naddale, Crofton, Chapel Sucken, Brayton.

Sparganium ramosum, Portinscale, Naddale; S. sim- 
plex, Harras Moor; S. natans, Shoulthwaite Moss. Carex dioica, Orgill ; C. pulicaria, Hunday; C. arenaria, Harrington shore; C. vulpina, Yeorton Hall; C. limosa var. irrigua, Gilsland, rare; C. pallescens, Sellafield; C. flava, Hardknot; C. extensa, Marron Side; C. stricta, Bullgill Bridge; C. riparia, Stubbin Mire; C. vesicaria, Braithwaite; C. ampullacea, Cocker Side; C. filiformis, Workington (Mr. Tweddle.) Many other Carices grow within the district.

Littorella lacustris, Derwent Lake, Wythburn. Urtica urens, Distington, Ullock. Myriophyllum spicatum, Naddale. Sagittaria sagittifolia, Braystones Tarn (Mr. Robson.) Arum maculatum, Wood Hall, Branthwaite.

Betula alba, var. pendulosa, round Derwent Lake.

Salix herbacea, Skiddaw top. Upwards of thirty species over West Cumberland.

Empetrum nigrum, moors and bogrs.

Humulus Lupulus, Keswick, Egremont.

Tamus communis, Millom, Eskdale.

Rhodiola rosea, Ennerdale Coves and Pillar Fell.

Taxus baccata, very large trees in Borrowdale.

Atriplex laciniata, St. Bees and Harrington shores; A. patula, Workington north shore.

Isoetes lacustris, Derwent Lake.

Subularia aquatica, Ennerdale Lake (Mr. Robson.)

Polypodium vulgare, common; P. Phegopteris, Eskdale, Ulpha, Braithwaite; P. Dryopteris, Legberthwaite, Dean.

Aspidium oreopteris, Ponsonby Fell, Ulpha; A. lobatum, Flimby, Walla Crag, Caldbeck; A. angulare, 
Whicham; A. spinulosum, Keswick, \&c.; A. dilatatum, Keswick, \&c.

Cystea fragilis, St. Bees Moor ; C. dentata, Naddale, Braithwaite, Whillimoor.

Asplenium Trichomanes, Carleton, \&c.; A. viride, Castlerigg Fell, river Irthing; A. marinum, St. Bees Heads ; A. ruta-muraria, common ; A. septentrionale, Borrowdale, near Lorton (Mr. W. Robinson); A. Adiantum nigrum, common.

Scolopendium vulgare, common in dark ravines; S. var. multifidum, Dearham ; S. var. crispum, Catgill Hall. Grammitis ceterach, Sandwith, Mosser, Gosforth, \&c. Blechnum boreale, common.

Allosurus crispus, Wasdale, Ponsonby, Lamplugh.

Hymenophyllum Wilsoni, Scale Force, Ponsonby ; H. Tunbridgense, Ponsonby Hall.

Osmunda regalis, Millom, Irton, Egremont, Ullock Moss.

Botrychim Lunaria, not rare on dry pastures. Ophioglossum, rather common.

Lycopodium clavatum, common on fells and moors; L. inundatum, Shoulthwaite, Wasdale; L. Selaginoides, L. Selago, Hardknot, Helvellyn, \&c. ; L. annotinum, near Bowfell (Mr. J. Flintoft); L. alpinum, Stye Head, \&c.

Equisetum arvense, common; E. fiuviatile, Flimby, Salter Hall, Parton Rocks ; E. sylvaticum, Watendlath, \&c.; E. palustre, Cold Fell (Mr. Robson); E. variegatum, Gilsland, in the Irthing. 


\section{DIRECTORY.}

The Address is that required by Postal arrangement. The name of the head office should be inserted at the end of each address, to ensure the regular transit of communications from a distance.

\section{WINDERMERE.}

\section{(Head Office.)}

Atkinson, James, lodging-house, | Brownrigg, John, joiner, BowVilla Lodge.

Aufrére, Geo., Ant. Esq., Burnside Ball, Jaines, railway clerk.

Balmer, Michael, Oak Bank, lodging-house.

Balmer, Grace, laundress, Old Field.

Barrow, R., Elim Grove.

Barrow, R., yeoman, The Grove. Barrow, Roger, Langdale View. Barrow, John, lodging-house, Woodside Cottage.

Battersby, Miss, lodging house, Bowness Road.

Bell, James, tinman, Cross-street Benson, Mrs., lodging-house, Bowness Road.

Benson, W., Esq., Dove Nest.

Birkett Mrs., lodging house, Elim Grove.

Birkett, J., Esq., Birkett Houses Bradford, Earl of, St. Catherine's Braithwaite, R., Esq., Bingle. Brockbank, John, lodging house, Bowness Road.

Brooks, Thomas, tailor and draper, High-street. ness Road.

Brockbank, John, confectioner, Bowness Road.

Bryans, James, Esq., J.P., Belfield.

Burnett, Rev Dr., Bowness Road Capstick, William, butcher, Cross-street.

Cartmell, William, joiner, Hazlethwaite Cottage.

Carter, Geo., artist, Elim Grove Clowes, Frederick, Esq., surgeon, Holly Hill.

Cowperthwaite, Christopher, painter, \&c., Church-street.

Craston, Miles, grocer, Bowness Road.

Crewdson, Geo. B., Esq., The Terrace.

Crosthwaite, Samuel, artist, Chapel House, Bowness Road. Crosthwaite, Thomas, yeoman, Allis How.

Davies, Mrs., grocer, Church-st. Dickinson, R. farmer, Winster. Dixon, Miss, dressmaker, Bowness Road. 
Eastted, William, Esq., Elleray. Edwards, Geo. 'T., Esq., Belmont Eglin, George, T., Post-office, Winster.

Elleray, Stephen, Winster.

Elleray, T., Winster.

Elleray, John, yeoman, Heathwaite.

Fell, Geo., yeoman, Common.

Field, John, Esq., Cross-street.

Fleming, John, farmer, Ecclerigg Fleming, Mrs., lodging house, Villa Lodge.

Fox, George, Esq., Windermer Terrace.

Gandy, John, Esq., Oakland.

Garnett, John, railway superintendent,-Printer, bookseller, \&c., Post-Office.

Gardner, Geo. H., Esq., solicitor, Ellerthwaite.

Greaves, Mrs., Ferney Green.

Greaves, Joseph, Ess., Birthwaite Lodge.

Graves, Rev. Robert P, Dove Nest.

Greg, Wm. R., Esq., The Craig.

Gregg, B., cordwainer, Elim Grove.

Harrison, Eldred, Esq., Windermere Terrace.

Harrison, Wm., joiner, High-st. Harrison, Mrs. Fancy Repository, High-street.

Hayton, John, joiner and grocer, Bowness Road.

Hayton, Richard, lodging house keeper \& joiner, Bowness Road

Herd, Thomas, grocer, Bowness Road.

Holmes, John, Grocer, High-st. Hornby, Rev. Jas. J., Wansfell. Holmes, Wm., surgeon, Cleator Lodge.

Holt, George, Esq., Orrest Head.
Howlett, Rev. Fred., Winster. Hudson, E. L., Eisq., surgeon hydropathist.

Humber, John, Esq., St. Mary's Cottage.

Hutchinson, Isaac, farmer, Common.

Hutchinson, Robt., No. 2, Railway Terrace.

Irving, B. A., M.A., St. Mary's College.

Jones, Robert, Esq., Elim Grove. Kennedy, Peter, Esq., Fair View. Ladyman, George, teacher, High Bowness.

Leighton, Miles, shoemaker, High-street.

Livesey, Jos., Esq., Green Bank. Logan, Robert, Low Wood Hotel. Longmire, J., farmer, Banrigg. Longmire, R., butcher, Lickbarrow.

Lowe, Myles, grocer, Old-road. Macdougall, Mrs., North View. Marriott, Miss, St. Mary's Abbey. Marriott, Mrs., Oakthorpe.

Medcalf, Richard, builder.

Melvillve, Thomas, agent, Storrs. Meyer, Miss, Holbeck Cottage.

Mitchell, Robert, blacksmith, Cross-street.

Mounsey, George, slater, Elim Grove.

Mounsey, W., joiner, Cross-st.

Newby, Jas., gardener, Elleray. Parrington, J., farmer, Dromer. Pattinson, Miss Betty, Woodland Grove.

Pattinson, Abraham, builder, Elim Grove.

Pattinson, John, lodging-house, Elim Grove.

Pearson, Mrs., Briery Close. Postlethwaite, Robert, joiner, Bowness Road. 
Pasley, Sir T. S., Craig Foot.

Puckle, G. Hale, M.A., St.Mary's College.

Richardson, Stephen, Village Inn

Rigg, Richard, Windermere Hotel.

Robinson, Miss, lodging-house, Howe Villa.

Salkeld, James, shoemaker, High-street.

Scholes, Mrs., Annesdale.

Scott, James, Victoria Hotel.

Shrigly, Miss, Langdale View.

Sheldon, Wm., coach-proprietor, Highfield.

Sill, John, flour \& butter dealer, Winster.

Somervell, Robert M., Esq., Halzthwaite.

Staniforth, Rev. 'Thomas, Storrs Hall.

Sternberg, Baroness de, Belsfield Swann, Napthali, grocer, Windermere House.
Swain, Jos., shoemaker, Cross-st. Swinburne, Edward, Esq., Calgarth Park.

Taylor, B., shoemaker, Winster. Taylor, John H., Esq., solicitor. Taylor, Mrs. l. h., Rock Side.

'Taylor, Samuel, Esq., (J.P.) Ibbotsholme.

Tyson, Miss, lodging house, Rock Side.

Ullock, Thomas, Esq., Quarry How.

Warwick, Thomas, blacksmith, Bowness Road.

Watson, Misses, Mylnbeck.

Watson, R. Luther, Esq., Ecclerigg.

Wilson, J., farmer, Cook's House Wilson, Capt., R.N., (J.P.) The Howe.

Wilkinson, Rev. H. J., Rectory. Wright, Henry, lodging-house, Bowness Road.

Yates, Miss Jane, The Wood.

\section{BOWNESS.}

Airey, John, farmer, Cleabarrow Allen, James, grocer and draper Armstrong, David, Museum. Atkinson, John, grocer \& draper Atkinson, James, saddler. Atkinson, J., waller, Millbeck Stock.

Barker, H., tailor and draper.

Barrow, James, joiner.

Barrow, R., yeoman.

Battersby, Thomas, gardener.

Battersby, Thomas, joiner.

Beetham, Ann, dressmaker.

Belcher, Lucy, bazaar.

Benson, Robert.

Birkett, W., gardener.

Blaylock, William, grocer.

Bownass, William, Royal Hotel.
Brockbank, William, carter.

Burton, Thomas, tailor.

Butcher, Mrs.

Braithwaite, John, boatman.

Barton, Miss.

Brockbank, John, painter.

Cloudsdale, Thomas, Crown Hotel.

Collinson, John, Esq., Brantfell Crosthwaite, Joseph, joiner.

Crosthwaite, John, grocer.

Curwen, Henry, Esq., Belle Isle. Cloudsdale, William, fisherman. Campbell, William, shoemaker.

Dickinson, R., Belfield Farm.

Dickinson, J., lodging-house, Dixon, 'Thomas, yeoman, Belman Ground. 
Dixon, Ann, upholsterer.

Dobson, William, blacksmith, lodging-house keeper.

Dobson, J., blacksmith.

Eccles, Thomas, post-messenger.

Eccles, R., joiner.

Fisher, James, lodging-house.

Fletcher, Joseph, cabinet-maker

Garnett, Edward, land-agent.

Gawith, John, carrier.

Gibson, G. Henry, Esq.

Gill, Dawson, ostler,

Gregg, Reginald, grocer.

Gregg, George, carrier.

Hadwin, J., cordwainer.

Harrison, J., beerhouse keeper.

Harrison, W., Brantfell.

Hartley, Thomas.

Herdson, J., High House.

Hiley, Mrs. M.

Hoggarth, Mary.

Holmes, Miss, milliner.

Holloway, William H., Esq.,

Waterside Cottage.

Holt, Frederic, gardener.

Jacob, Capt., Rayrigg.

Kendall, Greorge, painter.

Kirkbride, Charles.

Kirkbride, William, fisherman.

Lockett, Allen, lodging-house.

Longmire, Thomas, beerhouse.

Long, Miss, milliner.

Martin, John, beerhouse keeper.

Martin, Mrs., innkeeper.

Martindale, W., farmer, Barker Knot.

Mattix, Mrs., Berlin wool repository.

Millray, M. H., gardener, Belsfield.

Moon, James, yeoman.

Moon, Tobias, basket-maker, Belman Houses.

Newby, Christopher, coal-agent. Parker, Miss, milliner.

Poole, Abraham, Tower Wood. Redman, John, lodging-house. Reid, Robert, saddler.

Richardson, J., Commercial Inn. Richardson, T., farmer, Helm. Rigg, Ellen.

Robinson, Agnes.

Robinson, Agmes, Fell Side. Robinson, Amn, glass-dealer. Robinson, Robert, cordwainer. Robinson, R. James, lodginghouse.

Robinson, Thomas, tailor.

Robinson, William, waller.

Robinson, G., lodging-house.

Robinson, John, Lindeth.

Robinson, John, boatman.

Robinson, William, senr., joiner and bath-house keeper.

Robinson, William, junr., joiner and bath-house keeper.

Sabin, George, lodging-house.

Searle, H. lodging-house.

Sewell, Mrs., Fallbarrow.

Shaw, T., gardener.

Simpson, John, corn and fiour dealer.

Sowerby, Luke, basket-maker.

Stables, W., farmer.

Stewardson, R., beerhouse keeper

Stewardson, John, gardener.

Stringer, John, lodging-house.

Stringer, Henry, druggist.

Suart, Wm., junr., auctioneer.

Swainson, William, schoolmaster, Winster.

Tallon, Miss, confectioner.

Taylor, J., farmer, Low House.

Taylor, T., boat-builder, Low House.

Thompson, Isaac, beerhouse keeper.

Thompson, J., Esq., Bay Villa.

Turner, R., basket-maker, Millbeck Stock. 
Walker, A., beerhouse keeper.

Walker, Thomas, lodging-house.

Waters, George, ironmonger.

Webber, Lieut., Old England.

Wharton, J., hairdresser.

Wildman and Holmes, joiners and builders. Wilkiuson, William, blacksmith. Woof, Joseph, gardener.

\section{NEWBY BRIDGE.}

Ainsworth, T., Esq., cotton manufacturer, Backbarrow.

Astley, F. D. P., Esq., Fell Foot Backhouse, Simpson, farmer, Finsthwaite.

Barrow, Thomas.

Burns, J., farmer, Backbarrow. Bateman, Thomas, Beck Hire, beerhouse keeper and farmer. Bingland, Rev. J., Esq., Finsthwaite.

Braithwaite, Thomas, beerhouse keeper, Finsthwaite,

Carter, John, grocer, Staveley. Carter, Wm., hoop-maker and farmer, Finsthwaite.

Clarke, Miles, yeoman, Staveley. Cormic, William, Esq., Cunsey. Crow, Mark, farmer, Graithwaite.

Dixon, W., farmer, Cunsey.

Fell, John, Esq., Scott Park.

Fell, John, farmer, Finsthwaite.

Fell, John, blacksmith.

Fell, Christopher, bobbin manufacturer, Cunsey.

Fleming, D., Staveley.

Furness, W., Esq., Newby Bridge

Harrison, John, farmer and basket maker.

Anslie Harrison and Co., Iron

Works, Backbarrow.

Harrison, Mrs., Landing.

Kellett, Wm., carter, Landing,
Wilkinson, Rev. H. J., Rectory.

Wilman, William, plumber, \&c.

Wilson, Robert, farmer, Millerground.

Wright, W. James, Windy Hall. Wood, Jos., Temperance Hotel. Wood, Robert, beerhouse keeper.

Kirkby, James, grocer \& butcher Backbarrow.

Kirkbride, Robert, farmer, Finsthwaite.

Lewthwaite, G., Esq., Scott Park Martin, Joseph, farmer and land agent, Blakeholmes.

Pedder, John, Esq., Finsthwaite House.

Preston, W., farmer, Town End. Revley, M., farmer, Graithwaite Rigg, H. F., Esq., Staveley. Robinson, Wm., farmer, Scott Park.

Rowlandson, Joshua, quarryman, Town Ward.

Rowlandson, James, yeoman, Backbarrow,

Sandys, J. D., Esq., Graithwaite Steele, Christopher, shoemaker, Backbarrow.

Swainson, John, yeoman Helm Well, Cunsey.

Swainson, Jos., farmer and hoop maker, Cunsey.

Turner, J., farmer, Finsthwaite. Townley, E., Esq., Town Head. Welsh, Richard, coal dealer, Backbarrow.

Wharton, W., bobbin manufacturer, Scott Park

White, Thomas, Swan Hotel.

Wren, John, joiner and builder. 


\section{SAWREY.}

Arnold, James, Ferry Hall.

Apsland, T. Lindsey, Esq., artist, Sawrey Cottage.

Atkinson, E., hoop maker, Satter How.

Atkinson, John, Spout House.

Carradus, Barrow, farmer, Spout Mire.

Carradus, M., farmer, Harrow Slack.

Clark, Thomas, farmer, Satter How.

Cowburn, Mrs., Chapel Cottage. Cowpland, Mr., schoolmaster.

Creighton, Thomas, farmer, Fold. Dixon, J., grocer, Post Office.

Forrest, Mrs. M., farmer, Briers.

Forrest, John, yeoman, Low House.

Forrest, Mrs. Henry, widow.

Garnett, Joseph, Esq., Howend Cottage.

Halstead, W., Esq., Mount Cottage.

Hartley, Richard, New Inn.

Hawkrigg, T., blacksmith.
Hawkrigg, Braithwaite, yeoman. Hawkrigg, Hugh, yeoman, Castle Herdson, William, butcher. Huddart, J., seedsman, Waterloo Gardens.

Jackson, G., farmer, Eel House.

Ogden, Jonathan R., Esq., (J.P.) Lakefield.

Preston, William, farmer, Hill Top.

Smith, William, hoop maker. Smith, Elizabeth, grocer.

Stalker, John, grocer.

Stalker, Jonathan, beer-house keeper.

Stalker, Jonathan, basket maker. Stalker, W., boatman.

Taylor, Joseph, yeoman, Buckle Heat.

Taylor, Thomas, shoemaker.

Taylor, John, joiner.

Towers, W., yeoman, Towerbank. Towers, Mrs., Sawrey House. Willan, 'Thomas, spirit merchant. Willison, Ann, schoolmistress.

\section{TROUTBECK.}

Beaumont, Thomas, farmer, Crag Benson, Anthony, yeoman, Coat Syke.

Benson, William, farmer, Low Longmire.

Benson, Thomas, yeoman, High Green.

Benson, John, yeoman, Crosses.

Bigland, John, farmer, near Borrans.

Birkett, William, yeoman, Town Head.

Birkett, Thomas, yeoman, Great House.
Birkett, Robert, yeoman, Middleriggs.

Braithwaite, James, yeoman, Town Foot.

Braithwaite, Elizabeth, schoolmistress, Mathew How.

Braithwaite, John, mechanic, Troutbeck Bridge.

Brownrigg, George, joiner, Beckside.

Browne,Harrison,yeoman,Drummermire Head.

Browne, Mrs. Lucy, Town End. 
Browne, Richard, farmer, Low Wood,

Brown, Benjamin, yeoman, Boot. Coffee, Jeremiah, tailor, Crag.

Dawson, Mrs., Crag House.

Fell, Robert H., bobbin maker, Troutbeck Bridge.

Forrest, Birkett, yeoman, Low House.

Forrest, Matthew, farmer, Low Skelgill.

Green, Elizabeth, innkeeper, Mortal Man.

Harrison, Thomas, schoolmaster, Crag.

Hartley, William, farmer, Troutbeck Park.

Hayton, George, joiner, Town Head.

Hopkirk, James, Brow Head.

Hunter,'Thos. farmer, 'Town Head

Hutchinson, John, Esq., Broad Oaks.

Jenkinson, Thomas, yeoman, near Orrest.

Kennedy, Simon, letter carrier. Lancaster, Henry, bootmaker, Longmire Gate.

Lancaster,Thos. bootmaker, Lane Leather, Thomas, tailor \& draper, Mathew How.

Lingard, J. R., Esq., Holeherd. Longmire, James, farmer, Orrest Longmire, W., churchwarden, Crosses.

Longmire, John, yeoman, Longmire.
Longmire, J., yeoman, Butt Hill. Mackereth, Benson, innkeeper, Queen's Head.

Mackereth, W., yeoman, High Fold.

Mounsey, William, relieving officer, and registrar of births and deaths, High Fold.

Parker, Win., farmer, Limefit.

Pool, Joseph, yeoman, Slack Foot Postlethwait, James, innkeeper, Troutbeck Bridge.

Rigg, George, blacksmith, Longmire Gate.

Sewell, Rev. William, Low Fold. Stainton, Thomas, farmer, Town Head.

Storey, Thomas, yeoman, High Green.

Storey, Alison, farmer, Lane Foot Storey, George, waller, Lane Foot Storey, Christopher, farmer, Brow Top.

Thompson, J., innkeeper, Kirkham Top.

Todd, George, farmer, Long Green Head.

Todd, James, farmer, Crag.

Townson, Richard, farmer, Mid Town.

Tyson, Thomas, farmer, High Skelgill.

Tyson, Isaac, farmer, Town Head Wilson, Nicholas, yeoman, Town End.

Wilson, Nicholas, jun., farmer, Town End.

\section{AMBLESIDE.}

Abbott, John, saddler, coach / Atkinson, James, joiner, and office and lodging house, Fairfield.

Arnold, Mrs., widow of the late Dr. Arnold, Fox How.

lodging-house keeper, Fisher Beck.

Atkinson, J., saddler, \&c., Market Place. 
Atkinson, William, shoemaker.

Backhouse, James, farmer and lodging-house keeper, Rydal.

Ball, William, Esq., Glen Rothay

Barrow, John, farmer, Hawkshead Hill.

Barwick, John, surgeon.

Barwick, Thomas, carpenter.

Barrow, John, joiner.

Barton, Mrs., milliner.

Barton, William, schoolmaster.

Banks, G., upholsterer.

Barkworth, Alfred, Esq., Tranby Lodge.

Beck, James, farmer, Mire Side, Skelwith.

Bell, Catherine, stay maker.

Bell, R. F., ironmonger.

Bell, Thos., chemist \& druggist.

Bell, J., miller.

Benson, H., blacksmith, Blue Hill

Bonney, Richard, plumber.

Brenchley, Alexander C., Esq., Wanlass How.

Brown, John, Commercial Hotel.

Brocklebank, Benjamin, farmer, Stang End.

Birkett, George, cooper.

Backhouse, Wm., tarmer, Round Hill.

Carr, Thomas, Esq., Hill Top.

Carter, John, Esq., Rydal Mount

Clark, Miles, grocer.

Claude, Mrs. L., Broadlands.

Clay, Rev. J., Miller Bridge.

Cleminson, James, solicitor.

Clough, Mrs., Ladies' Seminary, Eller How.

Conway and Henshall, milliners.

Cookson, Miss, Clappersgate.

Cookson, Isaac, shoemaker.

Cousins, Henry, joiner.

Coward,John, joiner and lodging-

house keeper, Beech Cottage.

Coward, Wm., tailor and draper
Coward, Jeremiah, painter.

Coward, Jere., innkeeper, miller, and grocer, Skelwith Bridge.

Coward, John, bobbin manufacturer, Skelwith Bridge.

Cowperthwaite, George, farmer, Clappersgate.

Creighton, John, yeoman, Low Park.

Creighton, Joseph, blacksmith.

Crewdson, William Dillon, Esq., Field Foot.

Crosley, John, farmer, Hawkshead Hill.

Crosfield,John,Esq.,RothayBank

Davy, John, Esq., M.D., Lesketh How.

Dawson, Thomas, waller.

Dawson, James, Esq., (J.P.) Wray Castle.

Dawson, Miss, Randy Pike.

Dawson, D., farmer, High Park.

Dickinson, Miss, Nook End.

Dobson, Mrs., lodging house, Prospect Cottage.

Donaldson, P., Salutation Hotel.

Dove, Charles, farmer, postman, and fishmonger, Low Fold.

Dowling, Miss, Hill Top.

Dobson, -, Esq., Rothay Cottage.

Fell, Rev. S. I., Sweden How.

Fell, William, Esq., surgeon.

Fisher, Robert, lodging house, Stock Cottage.

Fisher, Robert, joiner.

Fisher, John, farmer.

Fleming, Mark, boot and shoe maker.

Fléming, Rev. Fletcher, incumbent, Rydal Lodge.

Fleming, Lady le, Rydal Hall.

Fleming, Mrs., draper \& milliner

Forrest, Mrs., lodging house, Windermere Lodge. 
Foster, Miss, Wray Cottage.

Frearson, Rev. S., baptist minister, Hawkshead Hill.

Garside, Samuel, painter.

Gibson, Mrs., grocer.

Gibson, William, tallow chandler Gill, Miss, Oak Bank.

Gill, Jane, dress and stay maker Grave, Mrs., Oxenfell.

Green, Mrs., Gale Cottage.

Green, James, butcher and lodg. ing house keeper, Fisher Beck Grier, John, florist and seedsman Hodgson, John, farmer, Hawkshead Hill.

Harrison, Matthew, Esq., (J.P.) Belle View.

Harrison, John, Esq., The Green

Harrison, Mrs., lodging-house, Chapel Cottage.

Harrison, Benson, Esq., (J.P.) Scale How.

Hawley, Capt. R., Rock Cottage.

Hawkrigg, Michael, mason.

Hawkrigg, Js., yeoman, Skelwith

Hawkrigg, Joseph, farmer, Park House, Skelwith.

Hayse, Robert, gardener and seedsman.

Head, Miss, Miller Bridge.

Herd, Edward, watch maker.

Higgins, Miss, Fancy Repository

Hodgson, Rev. William, Old Brathay.

Holme, John, tailor.

Holme, William, bread baker.

Holme, Jas., Esq., Croft Lodge, Clappersgate.

Hopkinson, B., Esq., The Oaks.

Horrax, Charles, bobbin manufacturer.

Irving, Mrs., lodging house keeper, Rydal.

Irving, William, cooper, Hawkshead Hill.
Jackson, Mrs., Waterhead House Jackson, Henry, Royal Oak Inn Jackson, Mrs., Newfield Cottage Jackson, Thomas, carter and coal agent.

Jackson, Arthur, mason and lodginghouse-keeper, Rose Cottage

Jenkinson, Wm., bread baker.

Jameson, Miss, Smithy Brow.

Johnson, Mrs., E., lodging-house, Chapel Hill.

Kitchen, Edward, basket maker, Low Fold.

Lancaster, Mary, butcher.

Leighton, George, plumber, \&c.

Lutwidge, Capt. H., R.N., The Cottage.

Mackereth, Thomas, farmer.

Martin, Richard, lodging-house keeper, Chapel Hill.

Martineau, Mrs. Harriet, The Knoll.

Mason, Miss, dress maker.

Matty, Robert, tailor and draper

Mayson, Bryan, plasterer and lodging house.

Morse, Miss, Gale Lodge.

Nelson, Christopher, draper.

Newby, James, draper, bank.

Newton, George Law, wine and spirit merchant, Waterhead.

Newton, Mary, draper and milliner.

Nicholson, John, Esq., solicitor.

Nicholson, Mrs. Agnes, stationer, Post Office.

Noble, James, painter.

Okill, Miss, Sweeden Bank.

Parker, John, slate merchant, Hodge Close.

Partridge, George, Esq., Covey Cottage.

Pedder, Mrs., Gale House.

Peill, William, hooper, cooper, and grocer. 
Pritchard, Mrs., bread baker.

Preston, Thomas, farmer, Mill Brow, Skelwith Bridge.

Proctor, Jonathan, lodging house, Hill Side Cottage.

Quillinan, Misses, Loughrigg

Holme.

Redmayne, Giles, Esq., Brathay Hall.

Reynolds, Mi., Esq., Ghyll Cottage Richards, John, boot\&shoemaker Riddle, Mrs., lodging house, Five-ways House.

Robinson, William, flag-merchant Blue Hill.

Ridgway, Mrs., Low Field.

Robinson, Bryan, farmer, Rock Cottage.

Roberts, Christopher, farmer, Ellers Brow, Skelwith.

Robinson, Mason, clerk, Gunpowder Works, Elterwater.

Robinson, John, Esq., manager of the Elterwater Gunpowder Works, Elterwater Hall.

Rogers, Major, Pull Cottage.

Rollinshaw, Anthony, boot and shoemaker, and lodging-house keeper.

Roughsedge, Hornby, Esq.,(J.P.) Fox Ghyll.

Sarginson, James, farmer and lodging house, Skelwith.

Stalker and Higgins, joiners.

Shepherd, William, lodgings, Waterhead.

Shepherd, James, Esq., surgeon. Slee, Lancelot, farmer, Arnside. Slater, Mrs., confectioner and lodging house.

Sproat, John, accountant and lodging house, Fairfield.

Sproat, Wm., boot \& shoemaker. Squires, Mrs., glass dealer and hairdresser.
Stainton, R., Golden Rule Inn.

Stalker, Betsy, grocer.

Stalker, Mrs. A., Springfield.

Stansfield, Mrs., Waterhead.

Suart, James, Esq., Low Fold.

Tatham, Rev., J., curate, Rydal.

Thompson, Joseph, boat builder.

Thompson, John, painter.

Thompson, Jonathan, grocer.

Thompson, Miss, lodging house,

Walton Cottage.

Thwaite, Joseph, bread baker.

Townson, Wm., carrier, White Lion Hotel.

Townson, Benjamin, tax collector, Woodbine Cottage.

Townley, Robert, Unicorn Inn. Troughton, Thomas, bookseller, \&c., Stamp Office.

Troughton, Miss, D., lodg-house

Tyson, T., farmer, Waterhead.

Tyson, Joseph, carpenter.

Tyson, Joseph, confectioner.

Walton, Edward, shoemaker.

Walker, Joln, grocer and confectioner.

Wilson, John, Esq., solicitor, Cross Brow.

Wilson, Thos, Esq., Clappersgate

Wilson, R., farmer, Rydal Nab.

Woodburn, John, grocer and game dealer.

Woodburn, Mrs., lodging house.

Woodhouse, Richard, gardener and lodgings, Haven Cottage. Woof, Mrs., farmer and lodgings, Low Fold.

Woodend, J., farmer, Nook End.

Wordsworth, Mrs., widow of the late Wm. Wordsworth, Rydal Mount.

Wilson, James, Christopher, Esq., Compston Lodge.

Wilson, John, farmer, Grove. Winder, Mary, grocer, \&c. 


\section{LANGDALES.}

Barrow, Henry, farmer and slater Hacket.

Bank, John, yeoman, Langdale Head.

Benson, Edward, yeoman, Low Millbeck.

Birkett, Rev. Stephen, incumbent, Chapel Style.

Birkett, Thos., farmer and slater, Ivy How.

Birkett, Jonathan, farmer, Wilson Place.

Bird, Isaac, slate merchant, Elterwater.

Bownass, William, cooper, Postoffice, Elterwater.

Dixon, James, farmer, Dale End. Fleming, William, miner and beerhouse keeper, Little Langdale.

Greenop, Robert, farmer, Oak How.

Gregg, John, farmer, Blea Tarn, Grisdale, John, farmer, Langdale Head.

Harrison, John, farmer, Busk. Hartley, Wilson, farmer, Bays Brown.

Hodgson, George, joiner and farmer, Colwith.

Hodgson, John, slate merchant and farmer, New Houses.

Hodgson, George, farmer, Side Houses.
Jackson, James, farmer, Elterwater Farm.

Kirkby, Henry, farmer, Raw Head.

Lishman, John, woodmonger and farmer, Bield.

Milligan, John, farmer, Wall End.

Postlethwaite, John, farmer, Langdale Head.

Rigg, Andrew, farmer, Harry Place.

Ritson, Joseph, provision dealer, Elterwater.

Robinson, John, Esq., Gunpowder Works, Elterwater Hall.

Shepherd, Edward, farmer, Colwith.

Stables, Henry, shoemaker and farmer, Wallthwaite.

Thompson, George, beerhouse keeper, and farmer, Millbeck.

Thompson, Wilson, farmer, Pye How.

Thompson, Thomas, farmer and assistantoverseer, Wallthwaite Tyson, John, farmer, Fell Foot. Tyson, Edward, innkeeper, Chapel Style.

Tyson, William, beerhouse keeper, Elterwater.

Youdel, John, yeoman, Ellers. Youdell, Josegh, yeoman, Low Birk How.

\section{CONISTON.}

Atkinson, Thomas, Waterhead Barrow, Edward, Black Bull Inn. Hotel.

Barnett, George, innkeeper. Barratt, Wm., Hollyhow Cottage Barratt, Joln, Esq., Holyworth House.

Barrow, Joseph, yeoman, Little Arrow.

Barrow, Wm., yeoman, Outrake. Barrow, Henry, yeoman, Heathwaite. 
Barrow, Adam, farmer, Cat Bank.

Barrow, William, farmer, Heathwaite.

Burrow, George, farmer, and wool stapler, Hallgarth.

Beever, the Misses, Thwaite.

Bell, William, joiner, Hawsbank

Benson. John, farmer, Yew Tree.

Boileau, Simon John, Esq., Parsonage.

Bowdin, Daniel, accountant.

Bownass, Wm., yeoman, Brow.

Bownass, Roger, yeoman, Dixon Ground.

Bownass, George, junr.

Bownass, Roger, draper, Postoffice.

Briggs, John, carrier.

Briggs, James, carrier.

Bywater, R. T., Esq., surgeon.

Chambre, Miss, Bank Ground.

Collinson, William, farmer, Low Yewdale.

Coward, Edward, farmer, Farend

Coward, Henry, grocer and carrier, Bridge End.

Coward, Edward, joiner, Saw Mills.

Diddams, John, school master.

Dixon, Benjamin, yeoman, Spoon Hall.

Dixon, William, yeoman, Dixon Ground.

Dixon, Joseph, grocer.

Dixon, John, tailor.

Fleming, George, butcher, Yewdale Bridge.

Fleming, Robert, blacksmith.

Fleming, John, shoemaker.

Gaskarth, Anthony, lodging house.

Grave, William, Railway Tavern.

Hall, Joseph, grocer.

Harker, Jas., Rising Sun, beerhouse.
Irving, I., farmer, Coniston Hall. Jackson, John, farmer, High Yewdale.

Jackson, Edward, farmer and slate merchant, Tilberthwaite. Knight, John, farmer and assesment overseer.

Knipe, Thos. and Jas., tailors.

Linton, William J., artist, Brantwood.

Marshall, J. G., Esq., M.P., Waterhead House.

Massicks, Isaac, Crown Hotel.

Massicks, Isaac, blacksmith.

Mason, Miles, yeoman \& waller, Low Houses.

Mandle, Thomas, slate merchant Mossop, Clement, tailor.

Milligan, Go., farmer, Tarn Haws Nicholson, Eleanor, grocer.

Parker, John, farmer and slate merchant, Holme Ground.

Pickles, Richard, farmer, Dixon Ground.

Pool, John, butcher.

Prickett, Richard, farmer, Dixon Ground.

Redhead, Edward, painter and glazier.

Romney, William, agent to $\mathrm{J}$. G. Marshall, Esq.

Romney, Mrs., Tent Lodge.

Shuttleworth, Joseph, farmer, Tent Lodge.

Shuttleworth, Wilson, butcher, Waterhead.

Smith, Wordsworth, Esq., Coniston Bank.

Smith, Mrs., Coniston Bank.

Spedding, John, yeoman, Bowmanstead.

Stables, Miles, corn miller.

Thwaites, William, shoemaker.

Tolming, Rev., Thomas, incumbent of Coniston. 
Townson, William, yeoman, Gill. | Wilson, John, carrier.

Tyson, George, tailor and draper. Tyson, J., yeoman, High Ground Walker, Henry, farmer and lodging house, Bank Ground.

Wilson, Wm., yeoman, Beckses. Wilson, Matthew, yeoman, Hollins Bank.

Wilson, Thomas, farmer, Coniston Bank.

Wilson, John, farmer, Rowlandson Ground.

Wilson, Wm., beerhouse keeper, Miners' Arms.

\section{GRASMERE.}

Airey, James, postmaster, Under How.

Arnold, Mrs., Helm Side.

Agar, Miss, Silver How.

Baldry, J., schoolmaster.

Brown, Edward, auctioneer and appraiser, Hollins Hotel.

Brocklebank, Edward, farmer, Underhelm.

Cookson, Thomas, farmer and lodging housekeeper, Dale End

Cookson, Mrs., How Foot.

Cowperthwaite, William, lodging house keeper, Church Stile.

Dixon, James, farmer \& builder, Bove Beck.

Fleming, Rev., Sir Richard, rector, Rectory.

Fleming, James, yeoman, Knott's Houses.

Fleming, John, provision dealer, Knott's Houses.

Farquhar, Lady, Dale Cottage.

Fletcher, Mrs., Town Head.

Fletcher, Mrs., Lancrigg.

Fleming, John, yeoman, Under How.

Gibson, Mrs., Kelbarrow.

Gibson, Miss, St. Oswalds.

Green, John, Esq., Pavement End.

Green, John, Esq., land agent, Rylands.

Green, William, yeoman, Beck Allans.
Greenhow, John, farmer, Ayeside Nook.

Garnett, Frank, shoemaker, Butterliphow.

Greenwood, J. Y., Esq., Wyke.

Green, Daniel, provision dealer, Pavement End.

Harrison, Thomas, farmer, and carrier, Gill Foot.

Hayton, Robert, farmer, Score Cragg.

Heelis, Stephen, Esq., solicitor, Forrest Side.

Hodgson, Levi, waller \& builder, Town End.

Howe, Rd., painter and glazier. Jenkinson, Daniel,farmer, Goody Bridge.

Johnston, Rev., William, Between Gates.

Luff, Mrs., Dale Cottage.

Mackereth, David, parish clerk, Wyke.

Mackereth, Gawin, boatman and guide, Town End.

Nicholson, Thomas, waller, \&c.

Pettitt, A., artist, Belle Vue.

Pettitt, George W., artist, Rose Cottage.

Phillips, Captain, The Wray.

Postlethwaite, Jos., blacksmith, White Bridge.

Rothery, Mary, farmer, Goody Bridge.

Sandford, T., Esq., Ben Place. 
Scott, William, general trader, Swan Inn.

Tyson, John, Esq., Kitty Cragg, yeoman.

Usher, Isaac, Red Lion Hotel.

Walker, Isaac, farmer, Broad Rain.

Walker, Mrs., grocer, Moss Side

Walker, Edward, blacksmith, Town End.

Webber, Mrs., Allan Banks.

Wilson, J., yeoman, Goody Bge. Wilson, Edward \& Sons, builders, Stubdale Cottage.

Wilson, John, builder, Horse Stead Cottage.

\section{HAWKSHEAD.}

Atkinson, Robert, police officer. $\Lambda$ tkinson, John, grocer.

$\Lambda$ tkinson, John, hoop manufacturer, Outgate.

Atkinson, Richard B., beerhouse keeper, Outgate.

Backhouse, Richard, farmer, High Wray.

Bainbridge, Mrs. Sarah.

Baisbrown, John, gardener and seedsman.

Baisbrown, Richard, earthenware dealer.

Bardsley, Thomas, schoolmaster.

Barker, John, painter \& glazier.

Beck, Mrs., Esthwaite Lodge.

Bell, Anthony, yeoman, Birkrey

Bell, Dorothy, tea dealer, Green End.

Benson, Thomas, farmer, Field Head.

Black, George, farmer, Atwood. Black, James I., officer of excise, Hannakin.

Bowman, Thomas, Esq., (J.P.) Rogerground.

Bownass, G., waller, Waterside. Bownass, William, calf dealer, Thompson Ground.

Braithwaite, George, boot and shoe maker.

Braithwaite, William, plasterer. Brockbank, Robert \& Matthew, joiners, Hannakin.
Burton, John, tailor and draper. Chapman, Ann, Hill Top.

Cooper, Mrs., Beckside Cottage. Coward, James, saddler.

Coward, Edward, farmer, Keen Ground.

Coward, William, miller, Hawkshead Mill.

Coward, William, flag merchant, Outgate.

Crawford, Rev. Samuel, Borwick Lodge.

Croasdale, John, farmer, Skinner How.

Croasdale Isabella, farmer, Sawrey Ground.

Dixon, James, waller, Croft Head.

Dowbiggin, James, auctioneer.

Dowbiggin, John, joiner.

Dugdale, Richard, farmer, Cragg

Dugdale, John, farmer, Tock How.

Forrest,W., farmer, Beyont Field Forsyth, John, wood monger, Field Head.

Fothergill, John, farmer, Esthwaite Hall.

Garnett, Mary, Borwick Ground Garnett, George, farmer, Sunny Brow.

Gill, Sarah, King's Arms Inn.

Green, Samuel, clerk and sexton Hale, Miss Elizabeth, dressmaker 
Hartley, William, bacon dealer and farmer, Tock How.

Hawkrigg, J. yeoman, Town End Hetherington, Sarah, oat-bread baker.

Hewitson, Miles, boot and shoe maker.

Hickie, Daniel Banfield, L.I.D., master of Grammar School.

Hodgson, Braithwaite, Esq., Green End.

Hodgson, William, blacksmith, Gallowbarrow.

Hopkins, Joseph, Esq., Belle Grange,

Hudson, R., farmer, Birkrey.

Huish, Calverly, Esq.

Hutchinson, John, boot and shoe maker.

Hutchinson, Margaret, confectioner.

Jackson, Richard, Sun Inn.

Jefferson, William, farmer, Borwick Lodge.

Johnson, -, Esq. M.D.

Keen, Jacob, farmer, Howe.

Kendall, Wm., yeoman, Hawkshead Field.

Kendall, Jas., yeoman, Hawkshead Field.

Kilner, Mrs., Richmond Villa.

Kirkby, Mat., farmer, Waterson Ground.

Kirkby, Robert, auctioneer, Colthouse.

Ladyman, G., Queen's Head Inn Leviston, George S., yeoman, Greystone Cottage.

Lodge, Edmund, Esq., Keen Ground.

Martin, J., hoop manufacturer. Martin, George, waller.

Medcalf, William, Esq., Mill Hill Cottage.

Milligan, Joseph, farmer, Castle
Milligan, Michael, farmer, Knipe Fold.

Newby, John, farmer, Foldyeat.

Nicholson, George, tailor and draper.

Noble, Robert, boot and shoc maker.

Noble, the Misses, drapers.

Noble, Mary, confectioner.

Noble, John, ironmonger and grocer.

Park, Rev. George, Parsonage, Walker Ground.

Park, William, joiner.

Park, James, swiller, Gallowbarrow.

Park, John, farmer, Dodgsonground.

Parker, Anthony, farmer,Hawkshead Hall.

Poole, John, butcher, Rogerground.

Poole, John, Esq., solicitor, Field Head House.

Postlethwaite, Isaac, tailor.

Purdie, James, tin plate worker

Raven, Mrs., Walker Ground.

Raven, Robert, saddler.

Rigg, John, clogger, Outgate.

Robinson, Thos., vetr. surgeon.

Rowlandson, Margaret, spinster.

Rowlandson, John, gentleman.

Satterthwaite, Thomas, cooper, Outgate.

Satterthwaite, 'Thomas, farmer, Loanthwaite.

Satterthwaite, Jonathan, bacon curer, Colthouse.

Satterthwaite, Wm., blacksmith

Scales, Roland, yeoman, Outgate.

Scott, Miss Deborah, dress maker.

Slater and Heelis, solicitors.

Steele, Jonathan, yeoman. 
Stolzman, Madame E., ladies' seminary.

Studdart, Robert, boot and shoe maker.

Swainson, G., farmer, Sike Side. Taylor, John, relieving officer.

Taylor, Ann, grocer.

Taylor, George, plasterer.

Taylor, Ferdinando, Red Lion Inn.

Taylor, the Misses, milliners and dress makers.

Taylor, Isaac, blacksmith, Hannakin.

Taylor, Joseph, beerhouse keeper, Waterbarnets.

'Taylor, John, waller, Sandground Usher, John, Brown Cow Inn.

Usher, Benjamin, waller.

Usher, John, waller, Sand Ground.

Walker, Thomas, carpenter, Gallabarrow.

Walker, Mary, grocer, Gallowbarrow.

Walker, William, bobbin manufacturer, Bobbin Mill Cottage

Walker, John Thomas, bobbin turner, Summer Hill.

Wardley, Joshua, farmer, High House.

Wardley, 'Thomas, farmer, High Barn.

Warriner, Thomas, yeoman, Outgate.

Watson, Charles, postmaster.

Watson, Gawn, tallow-chandler.

Watson, Ann, draper.

Whittaker, Mrs., Belmont.

Wilson, Mary, national school mistress.

Wilson, John, carrier.

Wilcock, Thomas, Esq., Lake Bank.

Wilson, William, Esq., land agent, High Wray.

\section{KESWICK.}

Alcock, Christopher, shoemaker. Alexander, Featherstonhaugh, grocer.

Allinson, Mrs.

Ansell, George, Esq., solicitor.

Apps, Mrs., stationer.

Atkinson, John, grocer.

Atkinson, Thomas, barber and parish clerk.

Atkinson, Matthew, guide and boatman.

Atkinson, William, lodging house, Derwent Terrace.

Atkinson, Miss, milliner and dress maker.

Bailey, Thomas, bookseller and stationer.

Banks, Misses, lodging house.

Banks, Mrs., Shorley Croft.
Banks, Joseph, lodging house.

Banks, Son \& Co., pencil manufacturers.

Banks, John, draper.

Barron, Edward, Esq.

Barrow, Joseph, grocer.

Battersby, Rev. T. D. H., (incumbent) St. Jolın's Parsonage Bell, - officer of inland revenue Bird, Isaac, police officer.

Blakey, William P., butcher and lodging house keeper.

Bowe, Joseph, King's Arms Hotel.

Bowes, William, edge tool manufacturer.

Boyer, Rev. R. B., curate of St. John's Church.

Brown, Dr. Derwent Terrace. 
Bromley, William, stone cutter. Buxton, Mrs., school-mistress. Camm, William, fishmonger. Cartmell, Mrs., lodging house. Christopherson, J., ironmonger. Clarke, R. \& W., woollen manufacturers.

Clark, John, brewer.

Cockburn, John, draper.

Cocken, Edmund, Esq., Chestnut Hill.

Coulthard, Jos., sawyer \& grocer.

Cowper, John, jeweller.

Crosthwaite, Mrs. Elizabeth, museum proprietor.

Crosthwaite, J. Fisher, postmaster and bank agent.

Crosthwaite, Joseph, joiner and cabinet maker.

Crosthwaite, Mrs., grocer.

Crosthwaite, Jonathan, farmer, Monks Hall.

Crosthwaite, J. \& R., tanners.

Crosthwaite, Misses, St. John'sstreet.

Crosthwaite, Abraham, grocer.

Dallow, Rev. Joseph, Harriman Field.

Dare, James, Esq., Chestnut Hill.

Denton, Misses, Main-street.

Denton, William, Esq., Greta Farm.

Dent, John, innkeeper, Waggon and Horses.

Dewar, Mrs., Govenor's House.

Dixon, Thomas, Plosh.

Dobson, James, chemist and druggist.

Dover, Mrs., Myrtle Grove.

Dowthwaite, Watson, shoemaker

Dunlop, Misses, The Hollies.

Dunglison, Mrs. Martha, matron of Charity House.

Edmondson, J., Castlerigg Farm
Edmondson, Mrs., lodging house Edmondson, Misses, Dixon's Row Elleray, Wm., dyer, Elm Grove. Elleray, Miss, Greta Cottage.

Fallows, Thomas, coach-office, barber, \&c.

Fenton, G. S., Esq., Brow Top.

Ferguson, James, Esq., artist, Plosh.

Fisher, Mrs., Fisher's Hotel.

Flintoft, Joseph, Esq., Larch House.

Foster, William, Heads Houses. Foster, Son, \& Co., pencil manufacturers.

Fowler, William, saddler.

Fox, Miss, schoolmistress, High Hill.

Frank, John, Queen's Hotel.

Gatey, Joseph, draper.

Gibson and Hodgson, builders.

Gibson, Anthony, actuary of Savings' Bank and assistant overseer.

Gillbanks, Wm., lodging-house, Chestnut Hill.

Gill, Miss, dressmaker.

Gill, Adam, George Hotel.

Gipps, Kev. H., M.A., Vicarage.

Goodfellow, Thomas, grocer.

Gordon, Mrs., lodging-house, St. John's-street.

Graham, Joseph, shoemaker.

Grave \& Son, woollen manufacturers.

Grave, William, breadbaker.

Grave, Miss, lodging-house, Shorley Croft.

Greenip, Miss, teacher, Gretastreet.

Greenip, William, naturalist, Plosh.

Greenip, John, grocer.

Greenhow, Jane, grocer.

Guy, Wm., pencil manufacturer. 
Hall, Jos., Esq., solicitor.

Hallewell, George, lodging-house

Halmarack, P., Prospect House.

Harrison, John, butcher.

Harrison, Peter, head master Free Grammar School.

Hewetson, Mrs., Main-street.

Highton, Edward, teacher, Brigham School.

Hodgson, Mrs., Penrith-road.

Hodgson, John, lodging-house.

Hogarth, Jonah, Chestnut Hill.

Holmes, Misses, Millfield.

Hudson, Mrs., Main-street.

Hudspith, John, agent to $J$. Marshall, Esq.

Hunton, Misses, Acorn House.

Hutchinson, Isaac, watchmaker.

Hutton, Miss, Derwent Lake road

Iredale, J., farmer, Greta Farm.

Irving, Dr., Main-street.

Irving, Nancy, draper.

Irwin, Thomas, shoemaker.

Irwin, Jane, breadbaker,

Ivison, Jas., printer \& bookseller, proprietor of the "Derwent. water Record."

Jackson, Mrs., Shorley Croft.

Jackson, Robley, breadbaker.

James, Joseph, blacksmith.

Kennedy, Thomas, draper.

Kirkbride, Mrs., grocer.

Knubley, Mat., relieving-officer.

Lamley, Miss, Dixon's-row.

Lancaster, John, gardener.

Lawson, William, builder.

Lightfoot, Miss, Acorn Cottage.

Lightfoot, Mrs. Wilson, lodging house.

Lightfoot, Miss, teacher.

Litt, Thomas, tailor.

Lockhart, Henry, butcher.

Main, Mrs., Skiddaw Lodge.

Main, John, draper.

Makemson, Robert, shoemaker.
Mark, Mrs., farmer, Great Crosthwaite.

Marshall, Henry C., Esq., Derwent Isle.

Matthews, William, butcher. Mawson, John, blacksmith. Mayson, Joseph, lodging-house, High-street.

Messenger, Mary, breadbaker. Minnikin, George R., nurseryman and seedsman.

Mounsey, Misses, Dixon's-row. Moore, Matilda, Dog and Gun. Musgrave, John, tailor.

Newby, Wm. L., civil engineer. Nixon, Miss, confectioner. Otley, Jonathan, St. John's-street Pape, William, Woolpack Inn.

Parker, William, grocer.

Pearson, F., Esq., Briery Hill. Pearson, Wm., provision dealer. Peat, Mrs., Laburnum House. Perring, Rev. A. C., incumbent of St. John's in the Vale.

Powley, Henry, carpenter.

Rigg, Robert, grocer.

Rooke, Mrs., Skiddaw Lodge.

Robinson, John, shoemaker.

Robinson, Misses, milliners and dressmakers.

Robinson, Joseph, Shoulder of Mutton Inn.

Rodger, Robert, painter.

Rookin, Mrs., Plosh Hall.

Ross, Isaac, Golden Lion Inn.

Rothery, C. W., Esq., Greta Hall.

Routledge, Thomas, sawyer.

Rucastle, Jeremiah, auctioneer.

Scott, Joseph, farmer.

Scott and Sons, woollen manufacturers.

Scott, Abraham, Black Lion Inn Scott, Jane, grocer.

Scott, Miss, Penrith-road. 
Scott, William, saddler. Scott, Mrs., Norman Terrace. Scott, John, millwright. Sealby, Isaac F., ironmonger. Sheldon, John, Greta-street. Shearman, Mark, joiner and. cabinet maker.

Simpson, Rev. T. B., M.A, Derwentwater Place.

Simpson, George, King's Head. Simm, Miss, Seminary, Greta Lodge.

Slack, Joseph, Esq., Greta Grove Smith, Thomas, earthenware dealer.

Southey, Miss, Lairbeck.

Stables, John, grocer.

Stanger, James, Esq., Lairthwaite.

Stanger, Mrs. Joshua, Fieldside. Stoddart, J., surgeon, Penrithroad.

Stoddart, Elizabeth, straw bonnet maker.

Sutcliffe, Miss, milliner, \&c.

Sutton, Miss, lodging-house, Castlerigg Cottage.

Swindle, Vipont, grocer.

Swinburn, Isaac, joiner and cabinet maker.

Teather, John, Royal Oak Hotel.

Temple, John, tallow chandler.

Thornton, Mrs., grocer.

Tickle, Mrs., Shorley Croft.

Todd, Joseph, Esq., Hawthorn Cottage.
Tolson \& Crowder, tailors and drapers.

Tolson, Joseph, shoemaker.

Tolson, Joseph, gardener.

Tyson, William, grocer.

Usher, Joseph, grocer.

Vickers, Elizabeth, dealer in meal and flour.

Watson, George, architect, Highstreet.

Watson, Mrs., confectioner.

Walker, Rev. J., Chestnut Hill.

Webster, Rev. A. R., Derwentwater Place.

White, John, breadbaker.

Wilkinson, $\mathrm{T}$., joiner.

Wilkinson, John, clogger.

Williamson, Mrs., Norman Terrace.

Williamson, Mary, innkeeper, Great Crosthwaite.

Wilson, Joseph, draper.

Wilson, John, teacher.

Wilson, Mrs., St. John's-street.

Wilson, Robert, brick and tile manufacturer.

Wilson, Joseph, nailor.

Wilson, Thomas, shoemaker.

Wilson, George, Woodman's Inn

Wood, Joseph, draper.

Wood, Henry, painter.

Wren, Abraham, pencil manufacturer.

Wright, C. H., guide \& botanist Younghusband, Mrs., Brow Top Younghusband, William, Rose and Crown Inn.

\section{PORTINSCALE.}

Bennett, Thomas, Ullock Moss. Clarke, A. R., Esq., mine proprietor, The Howe.

Dixon, Mrs. A., Derwentwater Hotel.
Fawcett, H. H., Esq., Powe House.

Favell, Mrs., Derwent Lodge.

Fisher, Joseph, Esq.

Fisher, Miss, lodging-house. 
Faulder, Robert, The Howe. Greenip, Mrs., grocer and $\mathrm{l} . \mathrm{h}$. Harriman, Thomas, yeoman. Knubley, R., joiner and 1. h. Lietch, Dr., Derwent Bank. Mitchell, Richard, cordwainer.
Muckle, Miss. Poole, Edwin, boarding house. Turner, Mrs., Derwent Hill. Thompson, Isaac, shoemaker. Tickell, Thomas, farmer, Ullock. Walker, Mr. John.

\section{BASSENTHWAITE AND UNDERSKIDDAW.}

Atkinson, John, yeoman, Bassenthwaite Halls.

Atkinson, Miss, High Side.

Briggs, Daniel, veterinary surgeon, Castle Inn.

Clarke, Wilson, farmer, Applethwaite.

Dover and Co., woollen manufacturers, Millbeck.

Dover, A., Esq., Skiddaw Bank.

Dover, Joseph, Esq., Low Grove

Ewart, John, yeoman, Barkbeth.

Fawcett, John, farmer, Bassenthwaite.

Farvett, Thomas, farmer, Bassenthwaite.

Folder, J., farmer, Dancing Gate

Hodgson, William, postmaster and surveyor.

Hodgson, William, farmer, Applethwaite.

Jeffrey, George, lodging-house, Rose Bank Cottage.
Monkhouse, Revd. John, Lyzzick Hall.

Perfect and Hansard Misses, Scarness.

Rooke, John, yeoman, Green Hill, Bassenthwaite.

Scott, Jane, farmer, Little Crosthwaite.

Spedding, Mrs., John, Oakfield.

Spedding, T. S. Esq., (J.P.) Mirehouse.

Stanley, Mark, farmer, Long Close.

Swinburn, Joseph, farmer, Millbeck Hall.

Taylor, Misses, High Side, Bassenthwaite.

Vane, Sir Henry, Bart., Armathwaite Hall.

Wake, Mrs., Ormathwaite House.

Wren, Isaac, farmer, Low Grove.

\section{BRAITHWAITE.}

Adamson, John, corn miller.

Bell, Thomas, blacksmith.

Brown, Isaac, corn miller.

Fearson, Isaac, butcher and innkeeper.

Fletcher, George, yeoman.

Gatey, William, tailor.

Gibson, Thomas, schoolmaster and postmaster.

Jopson, Daniel, joiner.
Lowdon, Wm., farmer, Uzicar. Muckle, George, Esq., Little Braithwaite.

Pennie, The Misses, Braithwaite Lodge.

Stamper, John, innkeeper, Braithwaite.

Tolson, Daniel, farmer, Uzicar.

Williamson, George, woollen manufacturer. 


\section{THORNTHWAITE.}

Bewsher, John, beer-seller. Crosthwaite, J., yeo., Hall Garth Fisher, Miss, Jenkyn Hill. Gibson, Miss, Powter Howe. Gate, John, Esq., Spring Bank. Lynn, Rev. John M., perpetual curate, Thornthwaite Parsonage
Mc. Glasson, Mrs., Larch How. Mitchell, Thomas, Swan Inn. Sanderson, John, yeoman, Thornthwaite Hall.

Sanderson, John, junr., farmer, Beckstones.

\section{BORROWDALE.}

Abbott, John, farmer, Manesty. Allison, John, junr., farmer, Rosthwaite.

Banks, Mary, lodging-house, Newton Place.

Birket, John, farmer, Seathwaite Dixon, John, agent to the Blacklead Mines, Seathwaite.

Dixon, Daniel, farmer, Stone-

Fisher, Abraham, Esq., (J.P.) Seatoller.

Heathcote, Miss, Borrowdale Gates.

Jackson, John, postmaster, Rosthwaite.

Jopson, Daniel, farmer, Seatoller Jopson, John, farmer, Chapel House.

Kirkby, George, farmer, High Lowdore.

Litt, Jos., farmer, Stonethwaite. Mackereth, Geo., farmer, Ellers. thwaite.

Mossop, Mrs., innkeeper, Lowdore Hotel.

Newby, Rev. George, perpetual curate, Borrowdale Parsonage Simpson, Thomas, Esq., Hazel Bank.

Simpson, William, innkeeper, Rosthwaite.

Slee, Adam, slate merchant, Quayfoot.

Teasdale, Isaac, farmer, Riggside Threlkeld, Thos., yeoman, Grange Threlkeld, Thos., junr., farmer, Grange.

Walker, Thomas, farmer, Thornthwaite.

Wilson, John, yeoman, Grange. Wilson, Joseph, yeoman, Rosthwaite.

Wilson, John, farmer, Watendlath.

Wren, Thomas, yeoman, Rosthwaite.

\section{DALE HEAD.}

INCLUDING WYTHBURN, LEGBERTHWAITE, AND ST. JOHN'S VALE.

Atkinson, John, innkeeper, and postmaster, Dale Head.

Bell, Joseph, miller.

Birkett, Charles, blacksmith.

Birkett, John, shoemaker, Wythburn.

Cartmel, Robert, farmer and butcher, Low Nest.
Dowthwaite, J., yeoman, Green. Gillbanks, John, yeoman, Wythburn.

Hardisty, B., Esq., Armboth.

Hawkrigg, John, yeoman.

Hawkrigg, Jane, Horse Head Inn, Wythburn.

Hind, John, yeoman, Wythburn 
Hudson, Richard, farmer, Lowthwaite.

Lawson, Rev. B. R., Wythburn. Midford, Robert, Esq., the Nest Morley, William, butcher, Armboth.

Robinson, John, joiner, Smithy House.

Stanley, Miles, waller \& farmer.
Stanley, Mark, Wanthwaite Mill Weightman, T. farmer, Armboth Westray, Jane, farmer, Armboth Wilkinson, John, yeoman, Shoulthwaite.

Wilkinsou, Jos., yeoman, Fisher Place.

Wilson, George, farmer, Armboth.

\section{THRELKELD.}

Cockbain, M., farmer, Souterfell | Morley, Thomas, butcher and Collinson, Rev. Thomas, incumbent, of Threlkeld.

Crozier, John, Esq., Riddings.

Greenhow, Thomas, yeoman. grocer.

Plasket, Thomas, Salutation Inn Porter, Mrs., White Horse Inn. Robinson, John, Doddick.

\section{VALE OF LOWESWATER.}

\section{(HFead Office:-Cockermouth.)}

Atkinsou, Rev. Jer., Parsonage. Pearson, Mrs., landowner, Low Bell, Richard, yeoman, Iatterhead.

Benson, Isaac, yeoman, Godferhead,

Beck, Joseph, blacksmith, Gillerthwaite.

Burueyat, Peter, yeoman, Latterhead.

Cuthbertson, John, farmer,

Watergate.

Collinson, -, Esq., Oak Bank.

Dixon, Wm., yeoman, Waterend

Fawcett, Jonathan, yeoman, Bar Yeat.

Ireland, Jane, landowner, Red Howe.

Johnston, Henry, tailor, Thackthwaite.

Norman, Lemael, joiner, Mancaster House.

Pearson, Henry, farmer and innkeeper, Church Stile.

\section{Park.}

Proddow, Simeon, yeoman, Ardale Place.

Sancton, Thos., post-messenger, old School.

Senhouse,Humphrey,gentleman, Low Park.

Simpson, Jonathan, farmer, Mill Hill.

Skelton, Miss, Foulsyke.

Topping, George, yeoman,

Thackthwaite.

Tyson, William, yeoman, Thack. thwaite.

Tyson, William, yeoman, Low Park.

Tyson, J., grocer, Gillerthwaite. Tyson, Isaac, joiner, Gillerthwaite.

Vickers, Mrs., Kirkhead.

Wilkinson, John, farmer and innkeeper, Mire Syke. 
VALE OF BUTTERMERE.

Benson, General, Hasness.

Clark, John, farmer, Syke House

Clark, Mrs., innkeeper, Fish Inn Cowman, Isaac, farmer, Crofts. Cowman, Joseph, innkeeper, Bridge Inn.
Fleming, Daniel, farmer, Wilkin Syke.

Jopson, Charles, gentleman, Wood House.

Nelson, Edward, farmer, Gatesgarth.

\section{PATTERDALE. \\ (Head Office:-Penrith.)}

Abbott, Joseph, farmer, Hartsop Alcock, Wm., joiner, Bleeze End Askew, Henry W., Esq., Glenridding House.

Backhouse, John, boatman.

Bell, John, mining agent, Glenridding.

Bland, Rev. J., Side, Placefell.

Dobson, Benjamin, yeoman, Newhouses.

Dobson, Hiram joiner and lodging-house, Newhouses.

Dobson, Lancelot, boot and shoe maker, Newhouses.

Gelderd, John, Family Hotel, (Post Office.)

Grisdale, Robert, farmer, Hartsop Hall.

Grisdale, George, yeoman, Greenbank.

Grisdale, John, farmer, Beckstones,

Grisdale, John, miller, Hartsop Mill.

Harrison, Thomas, Cross Keys Inn, Kirkstone Foot.

Hogarth, William, farmer, Deepdale Hall.

Irving, George, tailor \& grocer, Township.

Kirkland, John, farmer, Low Hartsop.

Lancaster, Joseph, cordwainer, Bridge End.
Leck, William, parish clerk and boatman.

Leck, J., blacksmith, Deepdale. Machell, Thomas, White Lion Inn, Township.

Martin, William, farmer, Side, Place Fell.

Martin, Miss, dressmaker, Side.

Marshall, Wm., Esq., Patterdale Hall.

Mattinson, W., carrier, Torwnship Matthews, James, bookkeeper, Greenside Lodge.

Mounsey, Daniel, Esq., Goldrill Cottage.

Mounsey, J., yeoman, Deepdale.

Mounsey, Daniel, yeoman, Bridge End.

Nelson, Aaron, schoolmaster.

Nelson, Hannah, schoolmistress.

Nicholson, Jos., farmer, Noran Bank.

Pattinson, J., yeoman, Hartsop. Pattinson, John, grocer, Tenter How.

Pattinson, Wm., waller, Gillside Peel, Edward, waller \& builder, Grasthwaite How.

Rickerby, Joseph, land-agent, Eagle.

Robinson, George, blacksmith, Scarfoot.

Robinson, Thomas, gentleman, Bank Cottage. 
Robinson, John, farmer, Gillside Rothery, Henry, farmer, Braysteads.

Stalker, Jane, farmer, Tenter How.

Thompson, Rev. John, Parsonage Thompson, Jos., tailor, Brother Field.

Thompson, John, farmer, Lane Head.
Todhunter, Jos., farmer, Glencoin.

Walton, John, gardener, \&c., Bridge Fnd.

Watson, Thomas, blacksmith, Row Head.

Wilson, Mrs., Placefield House. Winder, John, farmer, Cawdale Beck.

\section{MARDALE AND MEASAND.}

HAWSWATER.

Bland, Stephen, yeoman.

Greenhow, Thomas, farmer.

Holme, John, Esq., Chapel Hill.

Kitchen, Thomas, farmer.

Mawson, Aaron, yeoman.

Mawson, George, yeoman.
Nevinson, Henry, farmer.

Rigg, Jonathan, schoolmaster.

Towers, William, farmer, \& innkeeper.

Towers, Mark, farmer.

Watson, Isaac, farmer.

\section{VALLEY OF WASDALE HEAD.}

\section{(Head Office:-Whitehaven.)}

Braithwaite, Joseph, farmer, Middle Row.

Briggs, Robt, farmer, The Hall. Burns, William, farmer, Downi'th-Dale.

Colebank, Fletcher, farmer, Burnthwaite.
Kitchen, Rev. Jos., Middle Row Ritson, John, yeoman and boatman, Row Foot.

Ritson, Wm., farmer, Row Foot. Ritson, J., farmer, Burnthwaite. Robinson, Jefferson, farmer, Rowhead.

\section{VALE OF ENNERDALE AND KINNISIDE.}

Ashburner, Lawrence, innkeeper, Ennerdale Bridge.

Atkinson, Joseph, yeoman, Croft Foot.

Attwoor, Henry, Fisq., Hazel Holm.

Bell, Joseph, farmer, Whins.

Bowman, Mrs., Mireside.

Buchannan, James, guide, \&c., Angler's Inn.

Dixon, Thomas, yeoman, Whitebanks.
Fearon, John, miller, Ennerdale Mill.

Hunter, John, yeoman, Croft Brow.

Jackson, John, yeoman, High Cockhow.

Jukes, Rev. W. M., Parsonage. Kitchen, H., yeoman, How Side. Peel, Joseph, yeoman, Gill.

Pay, John, parish clerk, Lanefoot Robinson, John, joiner, Ennerdale Bridge. 
Shepherd, John, yeoman, Standing Stone.

Shepherd, Rob., yeoman, Logget Simpson, John, miller, Kinniside Mill.

Steel, John, yeoman, Gill.

Steel, Henry, yeoman, Cotta. Sumpton, Joseph, yeoman, Low Waterside.
Townson, W., yeoman, Swinside Tyson, George, innkeeper, Ennerdale Bridge.

Tyson, John, yeoman, Gillerthwaite.

Williamson, Joseph, shoemaker, Little Bridge.

Wood, Joseph, yeoman, Birk Moss.

\section{VALE OF NETHERWASDALE.}

Colebank, John, yeoman, Har- | Pharoah, Mark, mason, Blackrowhead.

Colebank, Ic., yeoman, Yewtree. Colebank, Ann, Sun Inn.

Douglas, Rev. John, Parsonage. Fletcher, Rob., yeoman, Churchstile.

Jackson, John, yeoman, Guards. Lewthwaite, Wm., Esq., Wood House.

Lindal, John, grocer and shoemaker, Lowwood.

Mossop, Hen., yeoman, Windsor Myers, Hannah, landowner, Gap Nicholson, Wm., yeoman, Gill. beck.

Porter, Joseph, yeoman, Buckbarrow.

Rawson, Stanfield, Esq., Wasclale Hall.

Sherwen, Wm., joiner, Mill.

Taylor, Isaac, yeoman, Old Strands.

Tyson, Ann, landowner, Low Greendale.

Tyson, Ruth, farmer, White Syke.

Wasdale, Ann, Bowderdale.

Wilson, Joseph, Strands Inn.

\section{VALE OF ESKDALE.}

Benson, Jonathan, yeoman, Paddockwray.

Hartley, Isaac, yeoman, Churchhouse.

Hartley, Jos., joiner, Moorhead. Hird, Henry, smith, Green. Millican, Thos., Woolpack Inn. Nichol, Joseph, Randlehow. Powley, Rev., Robert, Beckfoot. Rogers, W., King of Prussia Inn.

Russell, Wm., bobbin manufacturer, Esk Villa,

Russell, J., yeoman, Moss Grove Sharp, Jos., yeoman, Hollinhead Sharp, John, yeo., Fisherground Southward, John, Randlehow. Tyson, John, yeo.,Armont House Tyson, J., yeo., Borrowdale Place Wilson, Timothy, yeoman, Hows Wilson, John, Mason's Arms.

\section{BIRKER AND AUSTHWAITE.}

Bateman, Wm., yeo., Pennyhill. Sharp, Edward, yeoman, Low Dixon, Wm., farmer, Dalegarth. Birker.

Hartley, Henry, farmer, Birker- Southward, Nicholas, farmer, thwaite. Brantrake. 
Tyson, John, yeoman, Birker- Vickers, Isc., yeoman, Fieldhead thwaite.

Tyson, Thomas, yeoman, High- Wilson, Isaac, yeoman, Sword ground. House.

\section{VALE OF BRACKENTHWAITE.}

\section{(Head Office:- Ulverstone.)}

Bank, Jos., yeoman, Millerplace Head, Richard, yeoman, Hope. Bank, Thos., do. do. Dobinson, Thos., Scalehill Inn. Fisher, John, yeoman, Cornhow. Fisher, Mary, Palace How. Grindal, Jos., Lauthwaite Green Head, John, yeoman, Hopebeck. White, Rd., yeo., Miller Place.

Head, John, yeo., Turner How. Hunter, W., farmer, Low Hollins Hodgson, Jane, Millbeck.

Wood, Jonathan, Esq., Low House.

\section{DUNNERDALE AND SEATHWAITE.}

On the Lancashire side of the Duddon.

Allason, Mat., yeoman, Kelbank. Casson, Jos., yeoman, Kelbank. Casson, John, grocer, Whistlow Green.

Case, Hun., miller, Hesket Hall. Dawson, John, yeoman, Thrang. Dawson, John, yeoman, Hall Dunnerdale.

Dawson, Wm., yeoman, Newfield Dixon, John, yeoman, Hall Dunnerdale.

Dobson, John, yeoman, Stonester Gunson, John, yeoman, Birks.

Hellon, Jos., yeoman, Low Hall. Sharp, Law., yeo., Hawse House. Stable, Ed., innkeeper, Newfield Stephenson, Thos., grocer, Hall Dunnerdale.
Stephenson, Jas., yeo., Boll Hall Stephenson, John, yeo., Knott End.

Turner, John, schoolmaster, Beckhouse.

Tyson, Rev., John, minister of Seathwaite, Chapel Garth.

Tyson, D., yeoman, Cockleybeck Tyson, Hen., yeoman, Hinning. house.

Tyson, Jos., yeoman, Hollinhouse Tyson, William, yeoman, Turner Howe.

Walker, Jn., yeoman, Tonghouse Whinneray, Robert, yeoman, Greenbank.

Whinneray, William, yeoman, Whinneray Ground.

\section{VALE OF ULPHA.}

Allason, Henry, yeoman, Low and High.

Atkinson, William, joiner, Basebrown Ground.

Braithwaite, Joseph, yeoman, Hazlehead.
Carter, T., grocer, Church House Carter, William, grocer, Crook. Dawson, John, yeoman, Basebrown Ground.

Dawson, Wm., slate-merchant, Moorhouse. 
Dawson, James, shoemaker, Pennington, Phillip, yeoman, Bridgeend.

Dodgson, John, alehouse keeper, Browfoot.

Gaitskell, Wm., teacher, School Cottage.

Gunson, Joseph, miller, \&c., Old Mill.

Hird, Wm., blacksmith, Moorhouse.

Jenkinson, Robert, yeoman, Biggart Mire.

Kirkby, Robert, shoemaker, Church House.

Pearson, Rev., R., officiating minister of Seathwaite, Riverbank.

Pennington, Robert, yeoman, Biggart Mire.

Biggart Mire.

Pennington, Ic., yeo., Craghole. Pool, IVm., yeoman, Riverbank. Postlethwaite, William, tailor, Low Hurst.

Sawrey, J., yeo., Stonethwaite. Shuttleworth, Thos., innkeeper, Church House.

Stephenson, Thomas, yeoman, Holm Cottage.

Vincent, Charles, mining captain, Holehouse.

Walker, Rev. Jeremiah, minister of Ulpha, Low Hurst.

Whinfield, John, yeoman, Biggart Mire.

Whinfield, John, yeoman, Whinfield ground. 




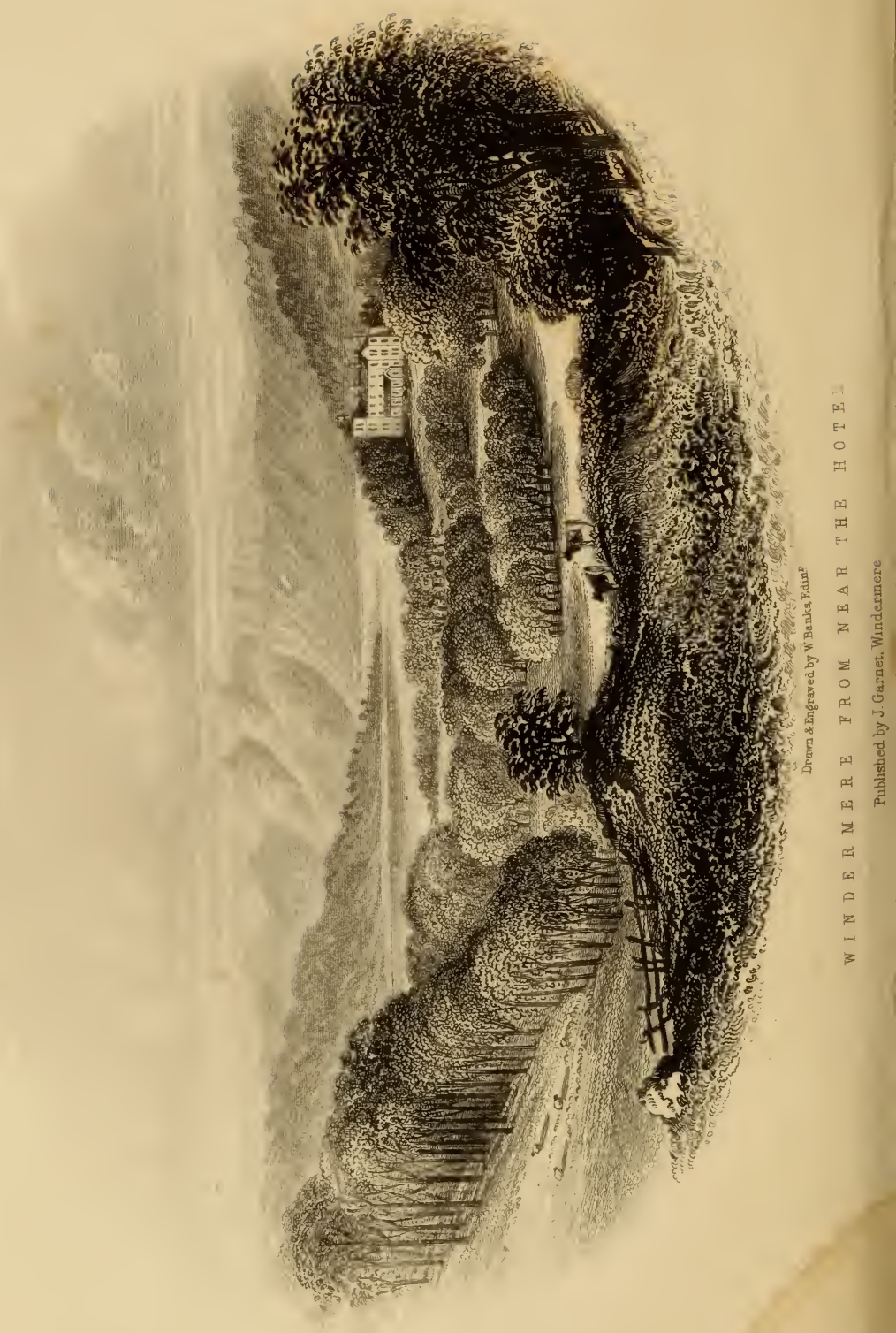




\section{ADVERTISEMENTS.}

\section{RIGG'S}

\section{W I N D RMERE HOTEL.}

At this Establishment, Families and others visiting the Lakes' District will meet with every accommodation and attention, combined with moderate charges.

The Hotel is on an eminence immediately above the terminus of the Kendal and Windermere Railway, and is so situated as to prevent the least inconvenience or annoyance from the traffic.

The views of mountain and lake scenery commanded from the windows of the Hotel are unsurpassed by any in the district the Lake Windermere with its numerous islands, being seen nearly to its utmost extent.

Open and Close Carriages, Cars, and Post-Horses always in readiness. 


\section{LIST OF VIEWS OF THE LAKE SCENERY}

BY THE LATE W. WESTALL, A.R.A.

Views at 3 s. each.

Bowness, Lake Windermere. - Rydal Lake from Rydal Mount. Ullswater, from Gowbarrow Park. - Ullswater, from near Pooley Bridge. - Keswick Lake, from Castle.-Keswick Lake, from near Water End. - Vale of Grasmere, from White Moss. - Windermere, from Elleray.

Views at 2s. 6d. each.

Vale of Keswick, from Ambleside Road. - Bassenthwaite, from Keswick Road. - Coniston Lake, from Bank Ground. - Keswick Lake, from Friars Crag. - Bowness Bay. - Whitehaven.

Views at 2 s. each.

Buttermere Lake, from North side.-Windermere, from Lowwood. Leathes Water, or Thirlmere. - Windermere from Ferry House. Views at $8 \mathrm{~d}$. each.

Keswick Bridge.-Keswick and Grisedale Pikes.-Keswick Lake from above Lowdore. - Keswick Lake, from near Water End.Stock Ghyll Force. - Lowdore Waterfall. - Skiddaw. - Keswick Lake, from Applethwaite. - Keswick Lake, from North side of Castle. - Keswick Lake, from Barrow Common.

Views at $4 \mathrm{~d}$. each.

Bowness, Windermere. - Windermere, from Bowness Road. Rydal, from the Wood.-Keswick from the North side. - Keswick Bridge and Greta Hall. - Ennerdale, from the North side.

Or the set in a neat wrapper at 2 s. each.

Views at 2 d. each.

Windermere Lake, from Troutbeck. - Rydal Lake.-Rydal Mount. - Room at Rydal Mount. - Grasmere Lake. - Grasmere, from Raise Gap. — Langdale Pikes. - Dungeon Gliyll. Leathes Water.-Keswick from Browtop.-Yowdore.-Ullswater.

Also the set in a neat wrapper at $2 \mathrm{~s}$.

Sold wholesale and retail by Garnett, Windermere, and retail by the principal Booksellers in the Lake District. 
ENGRAVING, LITHOGRAPHIC, STEEL, COPPERPLATE, AND GENERAL PRINTING ESTABLISHMENT.

26, Waterloo Place, Edinburgh.

\section{WILLIAM B A N K ,}

(Twenty-six years Manager and Draughtsman of the Engraving and Printing Establishment of $\mathrm{Mr}$. W. H. Lizars.)

Returns sincere thanks to his numerous friends, and the public generally, for the liberal encouragement given him since he commenced business in the above premises.

W. B. trusts from his long experience and practical acquaintance with the above departments of art, and by unremitting attention to the punctual and satisfactory execution of orders, coupled with moderate charges, to ensure a continued share of their valued employment.

W. B. will be aided in this by the exertions of his Sons, who have especially devoted themselves to the higher branches of

\section{Line Engraving, Bank Note Work, and other Commercial Forms,}

where elaborate pictorial embelishment is necessary.

His machinery is all of the most improved kind, the workmen carefully selected, and nothing but the best materials used.

Dasigns made for Illustrated Works, and engraved on Steel or Copper, in the best style of the art.

Bank Notes, Bills, Receipts, Letters of Credit, Cheques, Maps, Plans, Invoices, Letter Tops, Ornamental Display Bills, Labels, Circulars, Bills of Lading; Business, Marriage, or Visiting Cards, carefully and tastefully Engraved or Lithographed.

Die Cutting in all its branches. Fac-Similes of Old Deeds.

Seal and Wood Engraving. Envelopes Stamped, \&c., \&c.

Bookbinding by first-class hands. 


\section{BOWNESS, LAKE WINDERMERE.}

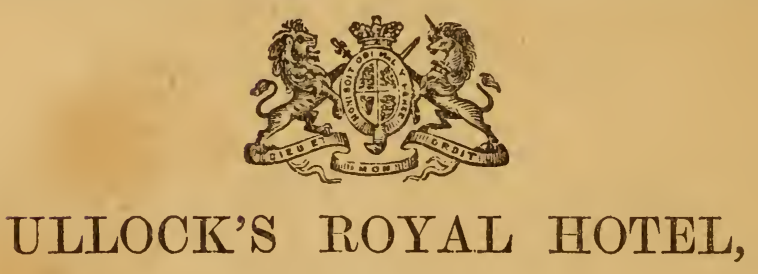

(Late White Lion.)

THE OLDEST ESTABLISHED HOTEL IN THE DISTRICT.

\section{W. BOW NAS, \\ PROPRIETOR OF THE ABOVE HOTEL,}

In returning his warmest thanks to the Royal Families, Nobility, Gentry, and the Public for the liberal support he has hitherto received, begs to assure his patrons that it shall be his continued study to merit a continuance of their support, by paying every attention to their comfort, combined with a strict view to economy and convenience of those who may favour him with their patronage.

Within a few years this Hotel has had the honour of receiving the patronage of the late Queen Dowager, the King of Saxony, the Prince of Prussia, the Grand Duke Constantine of Russia, and most of the principal English and Foreign Families of distinction visiting this romantic and interesting district. It is situated close upon the Lake, of which it commands extensive views, and within an easy day's excursion of all the principal Lakes and Mountains of the district.

Conveyances of every description kept.

Omnibusses meet every Train at the terminus of the Kendal and Windermere Railway, one mile and a-half from Bowness, and Private Carriages if required. Bowness is within nine hours of I.ondon, four of Manchester and Liverpool.

Agent to the Lancashire Insurance Company.-House and Estate Agent. 


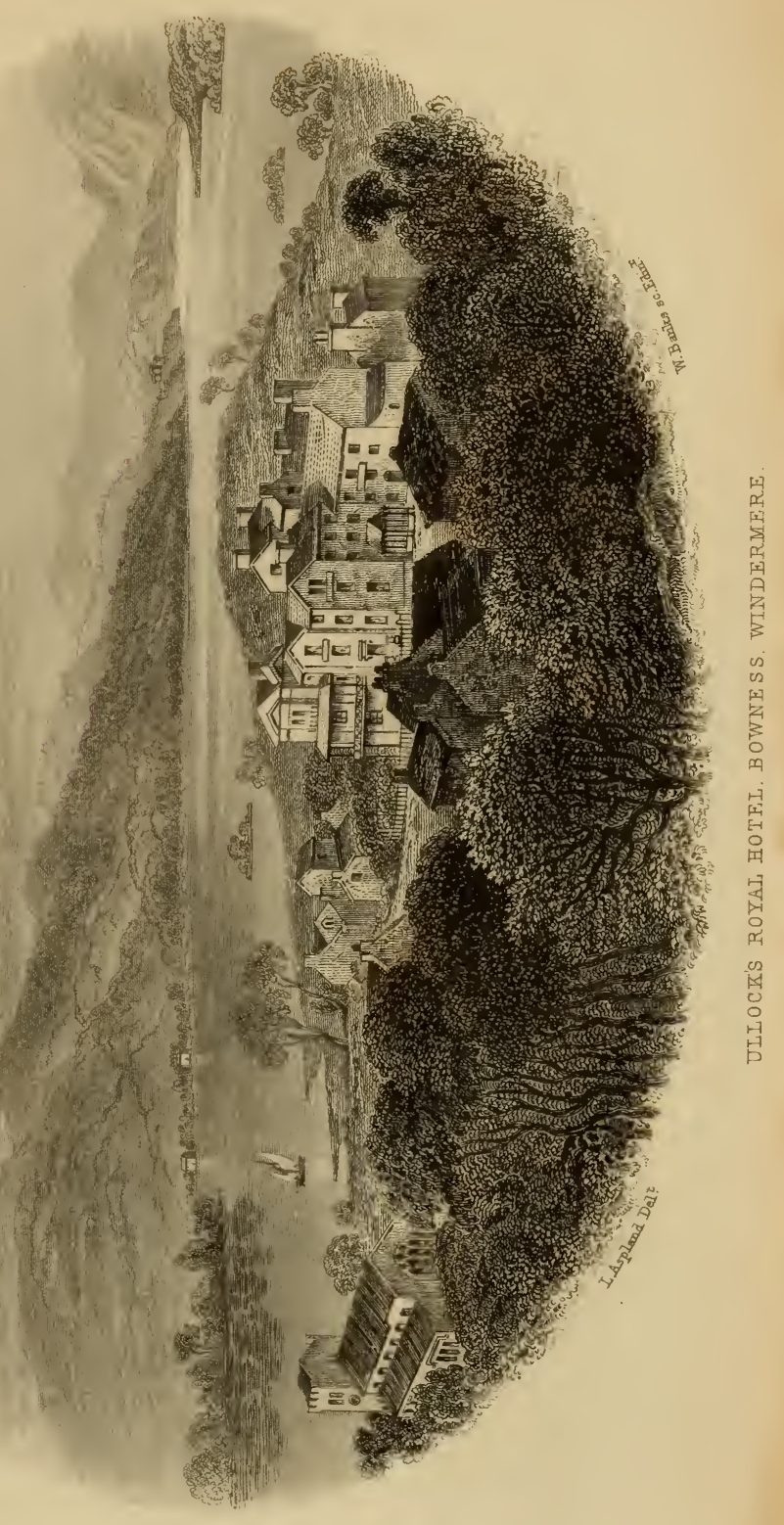





\section{JOHN ATKINSON, \\ KING'S HEAD INN, LEGBERTHWAITE, \\ Vale of St. John.}

BEST FISHING IN CUMBERLAND.

The King's Head Inn is situated -

$5 \frac{1}{2}$ miles south of Keswick.

5 miles from Threlkeld.

4. miles froun Borrowdale, over Armboth Fell.

6 miles from Patterdale.

$6 \frac{1}{2}$ miles from Grasmere.

3 miles from the summit of Helvellyn.

Tourists may here find good accommodation and well-aired beds.

The Mails change horses four times every day. A guide always in readiness at this Inn. A neat conveyance to he had.

\section{HAYTON'S LODGINGS,}

Are situate at Windermere Bank, near the village of Bowness, and close to the road from the Railway.

The View of the Head of Windermere from the Rooms is one of the most sublime and extensive in the district.

TERMS MODERATE.

\section{JOHN GRIER, \\ WATERHEAD NURSERY, AMBLESIDE.}

Lake Tourists and others are respectfully invited to visit the above Nursery, where will be found an extensive selection of Roses, also all the New Hardy Hybrid Rhododendrons, and a choice selection of Coniferæ, together with a general stock of Shrubs, Fruit Trees, \&c., \&c. Descriptive Catalogues may be had upon application. 
vi.

\section{KING'S ARMS HOTEL,}

COMMERCIAL INN AND POSTING HOUSE, KESWICK.

\section{J. $\mathrm{B} \mathrm{O} \mathrm{W} \mathrm{E} \mathrm{S,}$}

BEGS most respectfully to thank the supporters of his establishment for the patronage they have given him; and at the same time to inform them and visitors generally, it shall always be his study to give every satisfaction to his guests, without any regard to trouble or expense.

Open and Close Carriages, Covered Cars, Post Horses, and Mountain Ponies.

\section{RAMPLING'S WATERLOO HOTEL,}

(Opposite the General Post Office.)

WATERLOO PLACE, EDINBURGH.

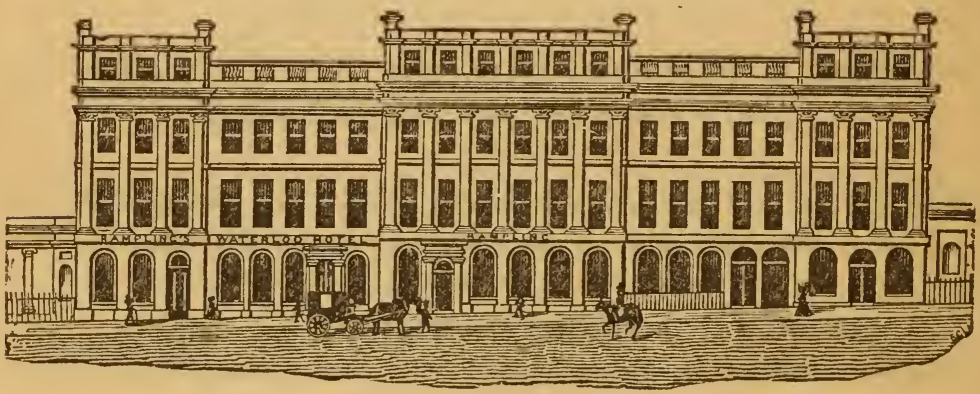

Commodious and elegant Coffee Room, large and well-ventilated Smoking Room. Suites of Apartments, \&c.

Strangers and others visiting Edinburgh will find that, for Situation, Comfort, and Accommodation, combined with Moderate Charges, this elegant and extensive Establishment (which was built expressly for an Hotel, at an expense of upwards of $£ 30,000$ ) is unequalled in the City. The Wines and Cuisine are of first quality. 


\section{H A R W O OD'S SPLENDID VIEWS IN THE LAKE DISTRICT.}

Ambleside. Ara Force, Gowbarrow Park.

Bowness.

Bowness Village.

Bowder Stone, Borrowdale. Buttermere \& Crummock Water.

Buttermere Hawes.

Buttermere Inn.

Coniston.

Derwent and Keswick.

Dunmail Raise.

Esthwaite Water.

Grasmere.

Greta Hall, Keswick.

Kendal.

" Highgate.

, Stramongate Bridge.

Naworth Castle.

Rydal Lake.

", a glimpse through the trees. Skiddaw \& Bassenthwaite Water Storrs Point.

Ullswater.

Wast Water.

Windermere, the Ferry Point. ", from Bowness. And a great variety of others.

Price, per Quire, on Cream Letter Paper, 3s. 6d., or $2 d$. each. " " $\quad$ Note Paper, 1 s. $9 d$., or $1 d$. each.

\section{THE ILLUSTRATED LETTER AND NOTE VIEWS}

Are one of the most pleasing and desirable objects which can be given to a correspondence between devoted and esteemed connections, and are meant to convey some idea of the locality and charms of the place of residence (especially if temporary); for then there is generally a freshness of feeling to appreciate the surrounding beauties in the most attractive and interesting subjects.

HARWOOD'S VIEWS IN THE LAKN DISTRICT. May also be had in Books, very neatly done up in Illuminated Covers.

Books, with Six Views, price 1s. Books, with Twenty-one Views, Ditto, with Nine, 1s. 6d.

Ditto, with Twelve, $2 \mathrm{~s}$.

Ditto, with Fifteen, 2s. 6 d.

Ditto, with Eighteen, 3s. price 3s. $6 \mathrm{~d}$.

Ditto, with Twenty-four, $4 \mathrm{~s}$.

Ditto, with Twenty-seven, $4 \mathrm{~s} .6 \mathrm{~d}$.

Ditto, with Thirty, 5s.

Sold by Garnett, Post Office, Windermere ; Belcher, Bowness ; Nicholson, Ambleside; Ivison, Keswick; Hudson, Robinson, Dawson, Atkinson, and Hargraves, Kendal; and all respectable Stationers and Booksellers. 


\section{THE EXHIBITION OF PICTURES,}

CONSISTING PRINCIPALLY OF

\section{VIEWS IN THE LAKE DISTRICT,}

Painted by $M r$. and Mrs. ASPLAND,

Will re-open for the season early in June, at their New Picture Gallery, near the Church, Bowness.

Visitors are requested to furnish themselves with Tickets of Admission, which may be obtained at the principal Hotels, and at Armstrong's Museum, or to present their cards of address.

\section{MRS. DIXON,}

\section{DERWENTWATER HOTEL, PORTINSCALE.}

The Hotel stands on the margin of the Lake, and commands extensive Views of the Lake and Mountain Scenery, and was patronized by Lord John Russell and family.

The Hotel is a quarter of a mile from Crosthwaite Church, and one mile distant from Keswick. The mails pass and re-pass daily.

Pleasure Boats, Post Horses, and neat Conveyances to be had at the Hotel.

TOWNSON'S HOTEL,

\section{WHITE LION AND COMMERCIAL HOUSE, AMBLESIDE,}

Is centrally situated, and affords to visitors every convenience for Lake and Mountain Tours, and at which will be found every comfort that Good Rooms, Cleanliness, Attention, and Moderate Charges combine.

There is attached to the Hotel a good Billiard Room. An Omnibus daily to meet the Steamers at Windermere Waterhead.

N.B. Parties may obtain on application every information respecting Private Lodgings. 



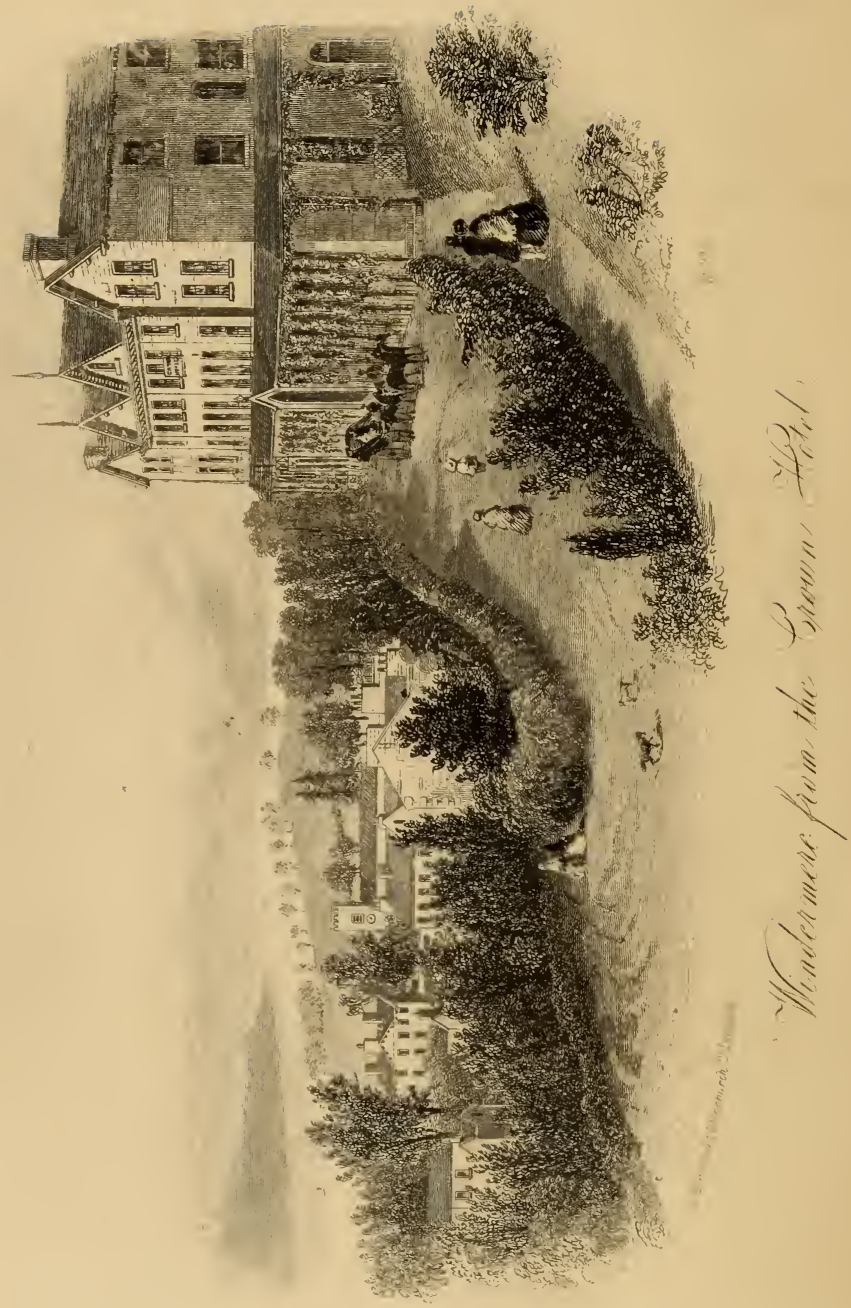


PATRONIZED BY THE ROTHSCHILDS'

\section{CLOUDSDALE'S CROWN HOTEL,}

BOWNESS, WINDERMERE.

N.B. THE CROWN is the large Hotel near the Lake, " furnishing Ninety Beds."

\section{GIBB'S HOTEL,}

\section{STIRLING.}

Tourists visiting Stirling and the Highlands will find that, for situation, comfort and accommodation, combined with moderate charges, this extensive Establishment is unequalled in the town.

Suites of Apartments, \&c., Commodious and Elegant Coffee Room for Ladies and Gentlemen.

Coaches daily during the summer months to Callander, the Trossachs, and Lochkatrine, at 9 a.m. and 4 p.m.; to Lochearnhead, Killin, Kenmore (Taymouth Castle), Aberfeldy, and Dunkeld, at 9 a.m.

Posting in all its departments.

An Omnibuss belonging to the Hotel waits the arrival of the different Trains and Steamers, to convey passengers and their luggage to the Hotel free.

A Note per post the day previous, addressed D. CAMPBELL, Gibb's Hotel, Stirling; Apartments, Post Horses, Carriages of any description, or Seats in the different Coaches will be secured.

This Hotel is within five minutes' walk of the ancient Castle of Stirling, the Railway Station, and the Steam Wharf.

P.S. - This is the only Hotel in Stirling in connection with M'Gregor's Hotel, Callander, and also M'Gregor's Hotel, Tros. sach's, Ardchiancrochan.

Gibl's Hotel, IIarch, 185̄6. 


\section{M. \& N. HANHART,}

64, CHARLOTTE STREET, RATHBONE PLACE, LONDON,

\section{LITHOGRAPHERS, DRAUGTSMEN AND LITHOGRAPHIC PRINTERS.}

THE LAKES OF CUMBERLAND AND WESTMORLAND.

LATELY PUBLISHED by M. AND N. HANHART, 64, Charlotte Street, Rathbone Place, London.

Price: Coloured, 2s. each ; Plain, 1s. each, A SERIES OF VIEWS of the most interesting Spots in the Lake District.

1. Ambleside.

2. Mill at Ambleside.

15. Keswick.

3. Ambleside Mill(SecondView) 17. Lowdore Cascade.

4. Stock Ghyll.

5. Grasmere.

6. Grasmere, from Redbank.

7. Rydal Water.

8. Rydal Upper Fall.

9. Rydal Lower Fall.

10. Kirkstone Pass.

11. Ullswater.

12. Patterdale.

13. Patterdale Church.

14. Airey Force.

18. Bowder Stone.

19. Two Inns, Buttermere.

20. Buttermere.

21. Crummock.

22. Scale Force.

23. Dungeon Ghyll.

24. Windermere.

25. Windermere Waterhead.

26. Windermere, from Lowwood

27. Windermere, from Bowness.

28. Wordsworth's Grave.

Messrs. Hanhart have also published Oil-printed fac-similes of original sketches by T. L. Rowbotham, of

TWELVE SKETCHES IN THE LAKE DISTRICT:Buttermere. - Skelwith Force. - Derwent Water. - Grasmere. - Wast Water. - Ennerdale. - Colwith Force.-Dungeon Ghyll. - Ullswater. - Scale Force. - Airey Force. - Keswick. All at Five Shillings each.

Printed and Sold by M. \& N. Hanhart, 64, Charlotte-Street, Fitzroy Square, London.

Architectural Drawings, Maps, Plans, Circulars, \&c. 


\section{THE AUTHOR'S EDITIONS.}

\section{OLLENDORFF'S METHOD of LEARNING to READ,} WRITE, and SPEAK a LANGUAGE in six months.

1. ADAPTED to the GERMAN. Written expressly for the English Student. By Dr. H. G. OllendorfF. In two parts. Part I., eighth edition, price 12s., 8vo., cloth. Part II., third edition, price 12s., 8vo., cloth. The parts sold separately.

** Introductory Book to Dr. Ollendorff's method adapted to the German, containing a new system of facilitating the study of the German declensions, and rules on the gender of substantives. 1.2mo, cloth. $3 \mathrm{~s} .6 \mathrm{~d}$.

2. ADAPTED to the FRENCH. Written expressly for the English Student. By Dr. H. G. OllendorfF. 8vo., sixth edition, containing a Treatise on the Gender of French Substantives, and an additional Treatise on the French Verbs. Price, 12s., cloth.

3. ADAPTED to the ITALIAN. Written expressly for the English Student. By Dr. H. G. OluendorfF. 8vo., third edition, price, $12 \mathrm{~s}$. , cloth.

KEYS to the ITALIAN, FRENCH and GERMAN SYSTEMS, prepared by the author. Price 7s. each, cloth lettered.

It is necessary for those who desire to avail themselves of the present method to notice that these are the only English editions sanctioned by Dr. Ollendorff, and he deems any other totally inadequate for the purpose of English instruction, and for the elucidation of the method so strongly recommended by Captain Basil Hall, and other eminent writers. They should be ordered with the publisher's name, and, to prevent errors, every copy has its number and the author's signature.

The above works are copyright.

London: Whittaker and Co., and Dulau and Co., and to be had of any boolsseller. 


\section{WINSOR AND NEWTON'S A RTIST' MATERIALS. JOHN GARNETT,}

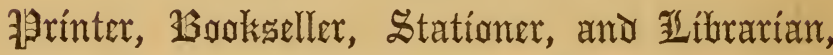
Post-Office, Windermere,

Respectfully begs to inform Lake Tourists and others, that he has constantly on sale Artists' Materials for Oil and Water Colour Painting, Sketching, \&c.; all the Guide Books, Views, and every other article in his business useful to visitors of the Lake District.

\section{HOUSE AGENT.}

All Parcels to or from J. G's Establishment conveyed in the district free of charge.

\section{A SERIES OF TINTED OUTLINE VIEWS,}

Drawn by T. L. Aspland, and engraved by $W$. J. Linton.

COMPRISING,

Across the Head of Stockghyll. - Windermere, from near Storrs. - Coniston, from near Bank Ground.-Upper Reach of Ullswater. - Grasmere, from Red Bank. - Derwent Water, from Castle Head.

4d. each, or the set in neat Packet, $2 s$.

\section{T R A V E L L I G M A P \\ OF THE}

ENGLISH LAKES AND ADJOINING COUNTRY.

Geologically Coloured, by John Ruthven.

Size $16 \frac{1}{2}$ by 18 inches. Mounted, in cloth case, for pocket, 2s. $6 \mathrm{~d}$.

"This is truly a beautiful chart. As far as our local knowledge enables us to pronounce, it is topographically most accurate, and the name of our townsman, John Ruthven, is a sufficient guarantee for correctness in the more scientific department." - Kendal MLercury.

J. Garnett, Windermere, and all booksellers. 
Now Ready, Price $1 s$.,

\section{A GUIDE TO WINDERMERE,}

With Tours to the neighbouring Lakes and other interesting places,

\section{BY HARRIET MARTINEAU.}

To which are added Excursions to and from Keswick, and an account of the Flowering Plants, Ferns and Mosses of the District, and a complete Directory.

Illustrated with a Series of new and beautiful Prints and an accurate Map.

"How different is her (Harriet Martineau's) air of conscious but matter-ofcourse superiority from the efforts of ordinary mortals who write Guide Books. If she gives herself the airs of an instructress the instructress soon shows herself to be a delightful companion." - Westmorland Gazette.

"Harriet Martineau has executed her task with her well-proved ability, and has produced a hand-book the most graphic in description and the most lively and vigorous in style that has yet appeared. - Kendal Mercury.

JUST PUBLISHED,

Handsomely bound in Cloth, Gilt, Demy 4to, price 10s., 6d.

A COMPLETE

\section{GUIDE TO THE ENGLISH LAKES, BY HARRIET MARTINEAU,}

Illustrated with a series of beautiful Steel Engravings and Coloured Prints, Elevations of the Mountains, and a large and accurate Map, coloured Geologically, by John Ruthren of Kendal; to which are added an account of the Flowering Plants, Ferns and Mosses of the District.

\section{Foolscap $8 v o$ edition of the above,}

Including a complete Directory to the District; best cloth, Gilt, 5 s.

Published by J. Garnett, Windermere. London: Whittaker \& Co. 
JUST READY,

\section{A SERIES OF HIGHLY FINISHED \\ VIEWS OF THE LAKES,}

Engraved in line, by W. Banks \& Son, of Edinburgh. COMPRISING :-

Grasmere, from Loughrigg Terrace, from a painting by George W. Pettit.

UlLswater, From the ENTRANCE to Grisedale, ditto, ditto. Stanley Ghyld, Eskdale, from a drawing by T. L. Aspland. Borrowdale, From near the Bowder Stone, ditto, ditto. Head of Windervere, from a painting by Alfred Pettit.

Derwent and Bassenthwaite Lakes, From Watenlath, ditto.

On large paper, 1 s. each.

Ackermann and Co.: London. - J. Garnett, Windermere.

\section{HIGHWAYS AND BYEWAYS}

\section{OF \\ ENGLISH LAKE SCENERY,}

Depicted in a series of Oil Paintings,

BY MESSRS. ALFRED AND GEORGE W. PETTIT'T, Now exhibiting at the

GALIERY OF FINE ARTS, GRASMERE,

Near the resting place of Wordsworth and Coleridge.

From these Pictures Tourists will gather much valuable information respecting the scenes worth visiting. They are selected with great care, and the outlines of the numerous Mountain ranges, are strictly true to nature. The collection consists of several Views of each of the principle Lakes, with the Tarns, Waterfalls, Passes, Rivers, and Abbeys of the district.

Visitors will find the Gallery (which has been built especially for this collection) an agreeable lounge at all times, and the pictures on its walls, a capitally Illustrated Guide through the Lake District.

Admission, 1s. - Tickets for the Season, 2s. 6d., may be had at the Gallery of Fine Arts, Grasmere. 
a 1 $\checkmark$

$$
-4
$$

$+$

$*$

I

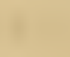

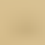

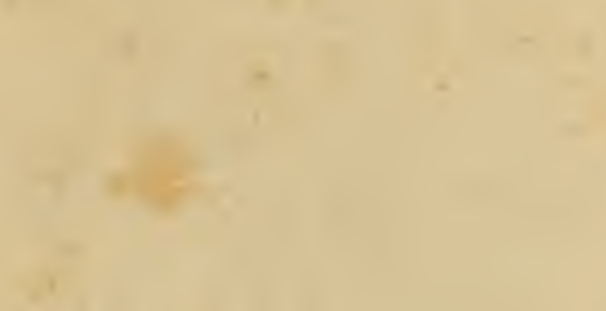

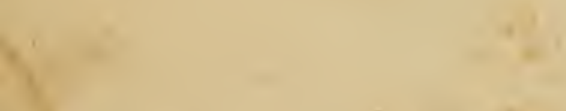

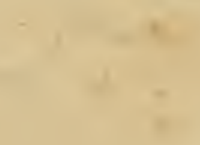

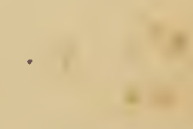

. r 


\section{\%}

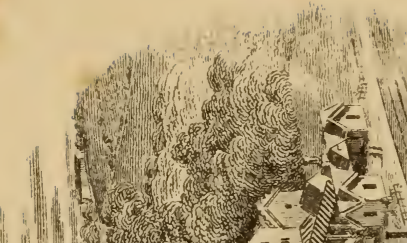

1. 19.

(1)

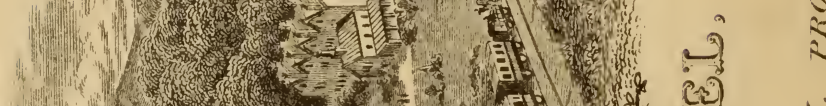

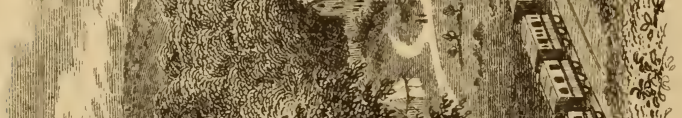

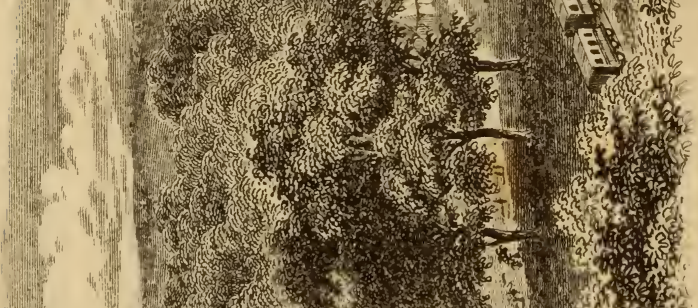

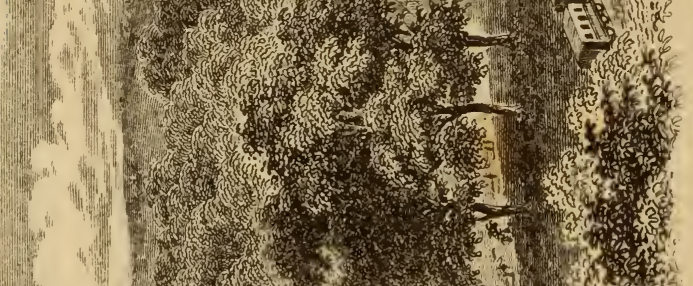

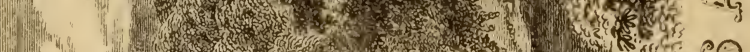

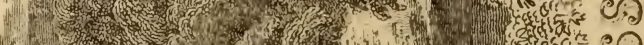

(2)

$\overbrace{}^{2} \rightarrow 0$ a.

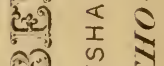

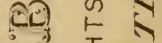

o.

U

4

○

c? 4

14.

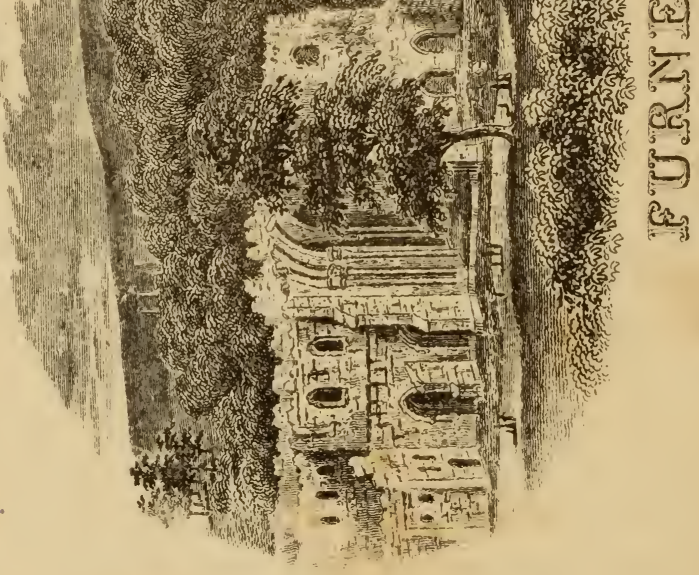

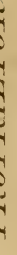




\section{FURNESS ABBEY HOTEL,}

\section{THOMAS SLANEY, PROPRIETOR,}

Begs to state that the above Hotel has been considerably increased in accommodation and furnished in a style that will insure to Families and Tourists patronizing it the comfort of a private house with the independence of an Hotel. First Class Coffee and Billiard Rooms.

\section{SCALE OF CHARGES.}

FIRST CLASS.
SECOND CLASS.

s. d

\begin{tabular}{llrr|llll} 
& & s. & d. & & & s. & d. \\
Breakfast - plain & $\ldots$ & 1 & 6 & Breakfast - plain $\ldots$ & 1 & 3
\end{tabular}

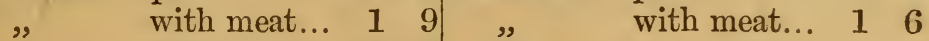

Dinners - Soup or Fish

with Joint or Cutlets,

\&c. $\ldots$ Extras charged as per Bill of Fare.

Luncheon or Suppers $\begin{array}{lllll}\text { Cold Meat } & \ldots & \ldots & 1 & 6\end{array}$

Dinner $\quad \ldots \quad \ldots \quad \ldots \quad 2 \quad 0$

26 Siugle plate of Meat and $\begin{array}{lllll}\text { Bread... } & \ldots & \ldots & 0 & 6\end{array}$ Large plate with Vegetables, \&c. $\quad \ldots \quad$... 10

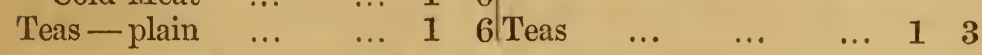

PORT AND SHERRY.

Dinner Wines, 4s., 4s. 6d., 5s. - First Quality 5s. 6d., 6s. Champagne, Hocks, Mosselles, Santerines, Clarets, Maderias.

Private Sitting Rooms 2s. 6d., 3s.6d., 5s.

Beds 1s. 6d., 2s., 2s. 6d.

Attendance will be charged in the bill.

Special accommodation will be provided for Excursionists by Cheap

Trains at very reasonable rates.

The magnificent Ruins close to the Hotel, are undergoing extensive additional excavations, which will greatly enhance their interests. Considerable improvement has already been effected; the removal of enormous accumulations of debris, \&c., having brought to view many additional basements of buildings in a good state of preservation, which previously were not supposed to exist. 


\section{ANNALES FURNESIENSES.}

The History of the Antiquities of Furness Abbey, by the late T. A. Beck, Esq., dedicated by permission to the Queen. With 26 Steel Engravings, by Le Keux, Wilmor, Carter, \&c.; also Woodcuts, coloured fac-similes, \&c., \&c. Royal 4.to.

This splendidly illustrated volume, of which 250 copies only were printed, and which sold for seven guineas, is now reduced to one-half, and will be sent, post-free, to address, by the present proprietor, S. SouLBY, Bookseller, Ulverston, Lancashire, who has purchased the remainder, on receipt of Post-office order for $£ 3$ 13s. 6d.

STEPHEN SOULBY, BOOKSELLER, ULVERSTON.

\section{LAKE DISTRICT COACHES.}

The undersigned beg respectfully to inform the Public that their Coaches run to and from all the Trains arriving and departing from the Windermere Railway Station, where a Clerk is always in attendance on the platform; also daily from the Penrith Station, Lancaster and Carlisle, to and from all parts of the Lake District.

For times of arrival and departure, see Bradshaw's Railway Guide.

JOHN TEATHER, Royal Oak Hotel, Keswick. JOHN GELDERD, Gelderd's Hotel, Patterdale. 


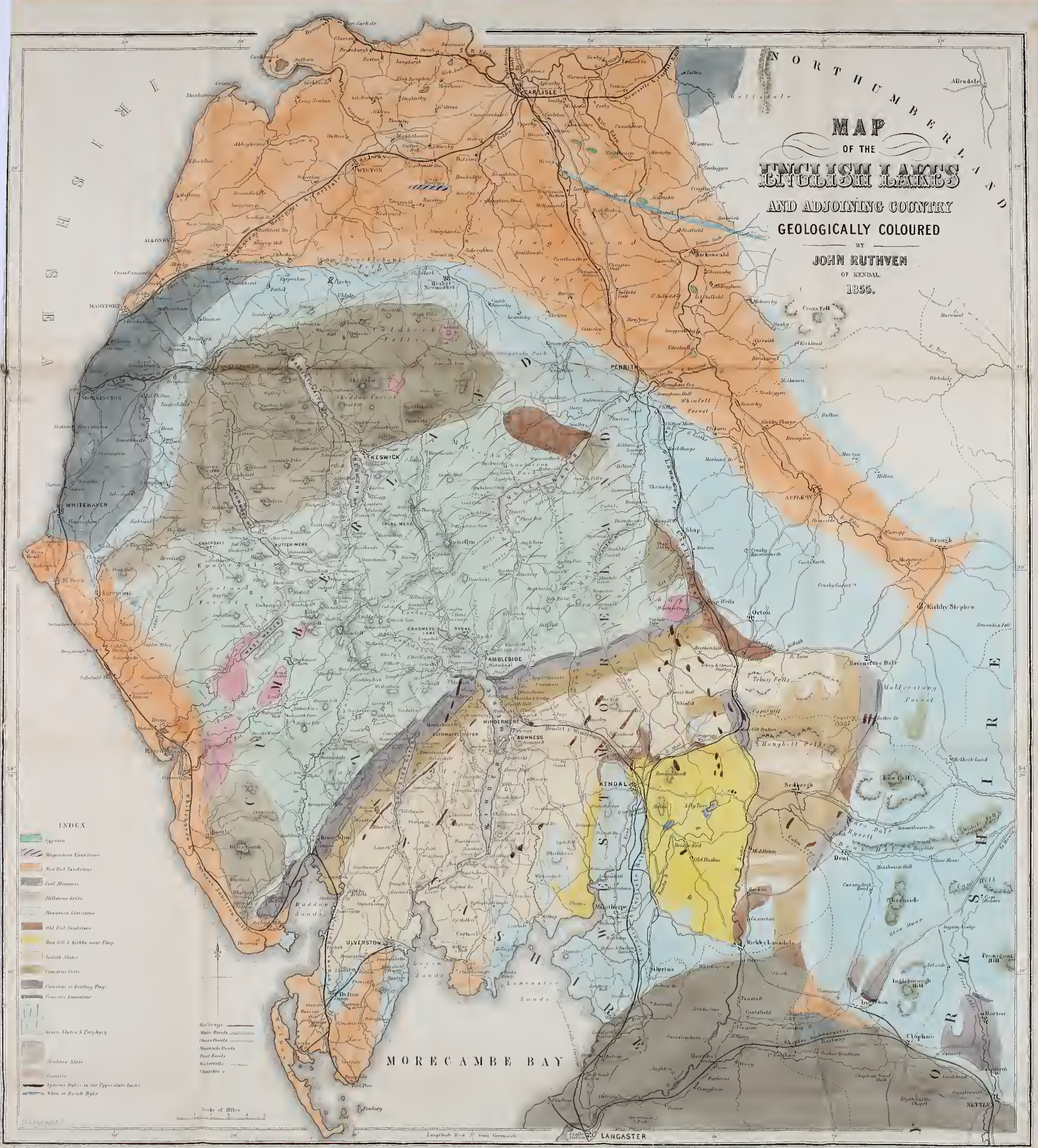


2

.

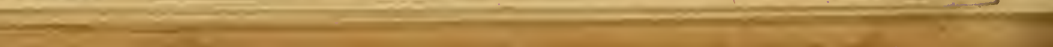




,

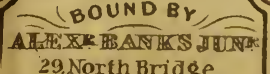


